\title{
Geology and Ore Deposits of the
}

Belo Horizonte, Ibirité, and Macacos Quadrangles Minas Gerais, Brazil

GEOLOGICAL SURVEY PROFESSIONAL PAPER 341-D

Prepared in cooperation with the Departamento Nacional da Produção Mineral of Brazil under the auspices of the International Cooperation Administration of the United States Department of State

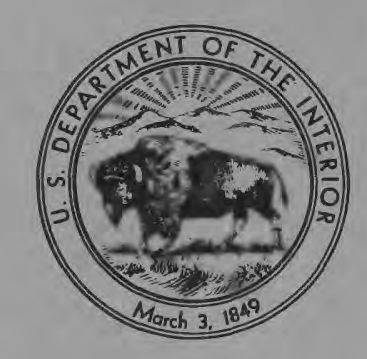




\section{Geology and Ore Deposits of the}

Belo Horizonte, Ibirité, and

Macacos Quadrangles

Minas Gerais, Brazil

By JOEL B. POMERENE

GEOLOGY AND MINERAL RESOURCES OF PARTS OF MINAS GERAIS, BRAZIL

GEOLOGICAL SURVEY PROFESSIONAL PAPER 341-D

Prepared in cooperation with the Departamento Nacional da Produção Mineral of Brazil under the auspices of the International Cooperation Administration of the United States Department of State

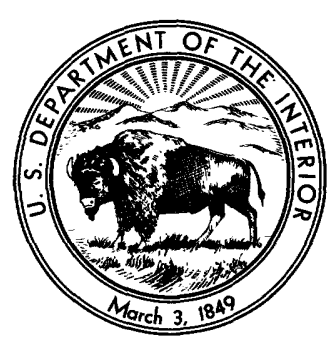




\section{UNITED STATES DEPARTMENT OF THE INTERIOR \\ STEWART L. UDALL, Secretary \\ GEOLOGICAL SURVEY \\ Thomas B. Nolan, Director}

For sale by the Superintendent of Documents, U.S. Government Printing Office

Washington, D.C., 20402 


\section{CONTENTS}

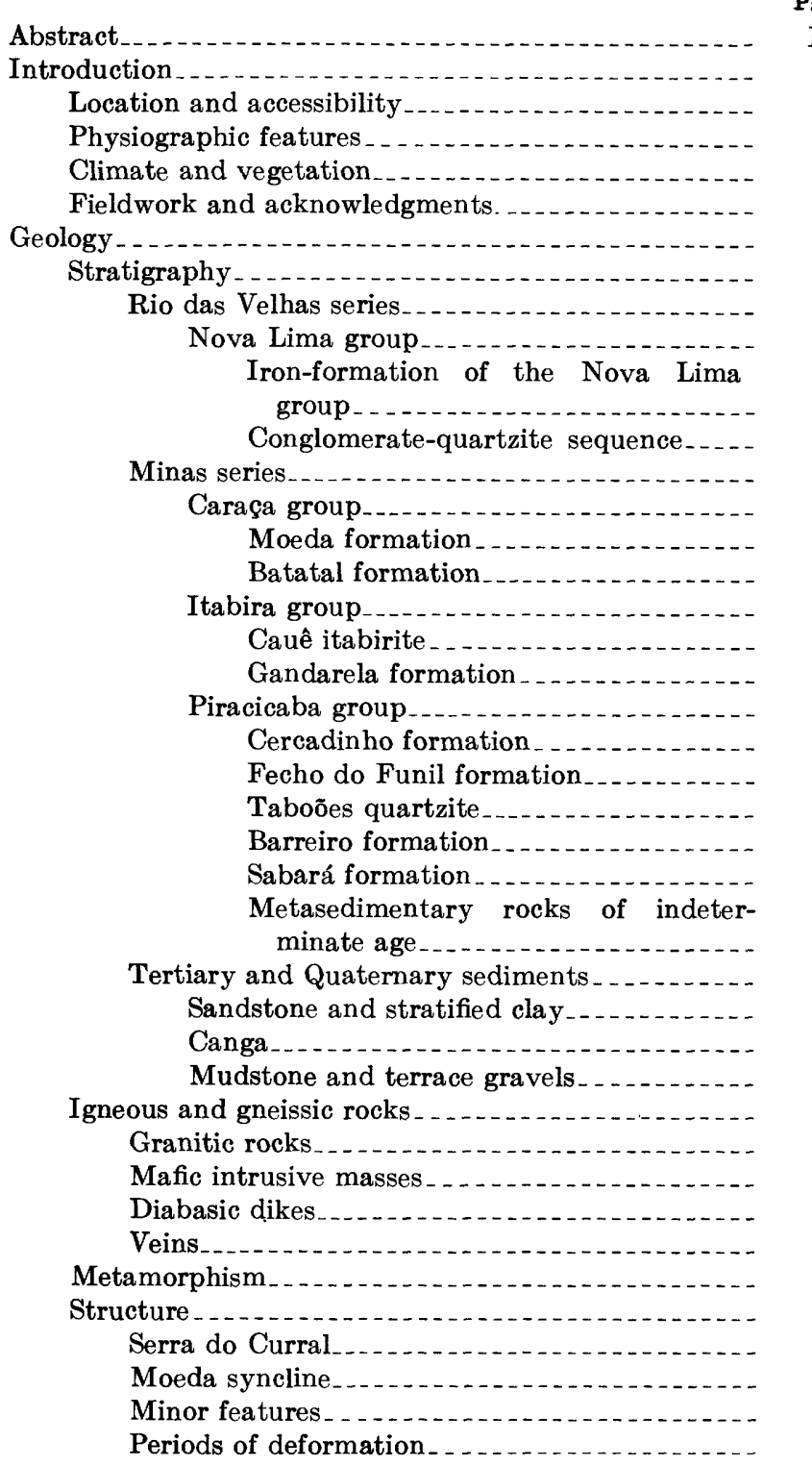

\begin{tabular}{|c|c|c|}
\hline Page & & Page \\
\hline D1 & Economic geology $\ldots \ldots \ldots \ldots$ & D41 \\
\hline 2 & Iron ore & 41 \\
\hline 2 & Types of iron ore & 41 \\
\hline 3 & Replacement ores & 41 \\
\hline 3 & Composition of the ore bodies...... & 41 \\
\hline 4 & Microtexture of the hematite & 42 \\
\hline $\mathbf{5}$ & Origin of the ore & 43 \\
\hline 5 & Soft itabirite & 44 \\
\hline 5 & Surficial ores & 45 \\
\hline \multirow[t]{2}{*}{5} & Chapinha & 45 \\
\hline & Surficially enriched itabirite $\ldots \ldots \ldots . .$. & 46 \\
\hline 7 & Canga & 46 \\
\hline 9 & Canga rica & 46 \\
\hline 10 & Rubble ore and rolados. & 46 \\
\hline 10 & High-grade hematite ore & 47 \\
\hline 11 & Taquaril & 47 \\
\hline 12 & Águas Claras & 47 \\
\hline 12 & Summary of Ȧguas Claras hematite de- & \\
\hline 12 & posits & 52 \\
\hline 15 & Fazenda Conde & 53 \\
\hline 20 & Tanque & 53 \\
\hline 20 & Barreiro or Mutuca no. 1. & 53 \\
\hline 24 & Jangada $\ldots \ldots$ & 53 \\
\hline 25 & Samambaia $\ldots$ & 55 \\
\hline 26 & Summary of Samambaia & 58 \\
\hline \multirow[t]{2}{*}{27} & Capão Xavier & 58 \\
\hline & Mutuca no. 2 deposit & 60 \\
\hline 28 & Zoroastro Passos & 60 \\
\hline 28 & Feixas area & 60 \\
\hline 29 & Tamanduá-Capitão do Mato-Serra da Gama. & 60 \\
\hline 30 & Summary of the Tamanduá-Capitão do & \\
\hline 30 & Mato-Serra da Gama region $\ldots . .$. & 71 \\
\hline 31 & Bauxite-1... & 72 \\
\hline 32 & Clay $_{1}$ & 73 \\
\hline 34 & Brick Clay & 74 \\
\hline 35 & Asbestos. & 74 \\
\hline 35 & Major underground workings & 74 \\
\hline $\begin{array}{l}36 \\
36\end{array}$ & Gold & 79 \\
\hline 37 & Manganese & 79 \\
\hline 37 & Building materials & 80 \\
\hline 39 & Literature cited & 80 \\
\hline 41 & - & 83 \\
\hline
\end{tabular}




\section{ILLUSTRATIONS}

[Plates are in separate volume]

Plate 1. Geologic map of the Belo Horizonte quadrangle.

2. Geologic map of the Macacos quadrangle.

3. Geologic map of the Ibirité quadrangle.

4. Map of Mannesmann adits with analyses of ores.

5. Geologic section along the tunnel through Serra da Rola Moça.

6. Columnar section of the Cercadinho formation.

7. Geologic sections.

8. Geologic map and cross sections of Ảguas Claras.

9. Geologic map of exploration adits at Ȧguas Claras.

10. Geologic map of Jangada.

11. Geologic map of Samambaia.

12. Geologic map of Tamanduá-Capitão do Mato-Serra da Gama.

13. Geologic map of the Cruzeiro mine (asbestos).

Figure 1. Index map showing location of the Belo Horizonte, Macacos, and Ibirité quadrangles.

2. Geologic map of the Quadrilátero Ferrífero

3. Boulder conglomerate

4. Chapinha

5. Geologic map of the Acaba Mundo area

6. Rhombohedral blocks of hematite from the Gandarela formation

7. Fluorite-bearing vein

8. Columnar section of the lower part of the Piracicaba group

9. Hematite concretions ...........

10. Cercadin ho formation; ferruginous quartzite

11. Graphitic phyllite

12. Tertiary fossils

13. Canga

14. Surface of fresh chemical canga

15. Weathered chemical canga

16. Narrow pegmatite vein

17. Fault in granite

18. Mafic xenolith in granite gneiss

19. Xenolith in granite.

20. Granitic rock intrusive into schist

21. Rutile and octahedrite inclusions in quartz

22. Quartz crystal containing carbonate rhombohedrons

23. Simplified sketches to show the development of a hypothetical set of faults

24. Compression fold in itabirite

25. Small compound synclinal fold in itabirite

26. Bedding and cleavage in phyllite of the Rio das Velhas series.

27. En echelon microfaults in itabirite .

28. Freehand sketch showing replacement of magnetite by hematite

29. View showing line of demarcation between soft red itabirite above and black and white itabirite below

30. Geologic map of the Taquaril area.

31. Sketch map showing iron content of surface samples at Äguas Claras.

32. Geologic map of Fazenda Conde ore area

33. Jangada (photograph)

34. Index map of the Macacos quadrangle

35. Geologic map of Capão Xavier and vicinity

36. Geologic map and section of the Mutuca no. 2 deposit.

37. Geologic map and section of Zoroastro Passos

38. Geologic map of the Feixos area.

39. Vertical view of hard hematite

40. Geologic map of the serpentinite area

41. Geologic map of Mine 1 (asbestos)

42. Geologic map of Mine 6 (asbestos)

43. Geologic map of the Raposal mine (asbestos) 


\section{TABLES}

TABLE 1. Rainfall and temperatures at Nova Lima, Minas Gerais, Brazil

2. Stratigraphic column of the Quadrilátero Ferrífero, Minas Gerais, Brazil

3. Analyses of dolomite, Belo Horizonte and Macacos quadrangles, Minas Gerais, Brazil

4. Analyses of ocherous itabirite near Lagõa Seca, Belo Horizonte quadrangle, Minas Gerais, Brazil. . . . . . .

5. Section of the lower part of the Piracicaba group, Ibirité quadrangle N. 7,500, E. 7,850

6. Section of Taboões quartzite, Barreiro formation, and lower part of Sabará formation, Piracicaba group, Minas series, Ibirité quadrangle N. 5,700-E. 2,500

7. Section of a part of the Piracicaba group at the type locality of the Barreiro formation, Ibirité N. 12,800, E. 12,670

8. Section of the Barreiro formation

9. Section through railroad cut at Ibirite N. 11,600-E. 4,600 measured from northwest to southeast $\ldots$

10. Analyses of the itabirite shown in figure 29.

11. Ore estimate, Taquaril, Belo Horizonte quadrangle

12. Ore estimates, Āguas Claras, Belo Horizonte quadrangle...

13. Ore estimate, Fazenda Conde, Belo Horizonte quadrangle

14. Ore estimate, Jangada, Ibirité quadrangle

15. Ore estimate, Samambaia, Ibirité quadrangle

16. Ore estimate, Capão Xavier, Macacos quadrangle

17. Ore estimate, Mutuca no. 2 deposit, Macacos quadrangle

18. Ore estimate, Feixos area, Macacos quadrangle . . .

19. Analyses of drill cores and sludges from two holes drilled in area 56, Capitão do Mato Norte

20. Ore estimate for Tamanduá-Capitão do Mato-Serra da Gama

21. Summary of hematite ore reserves in the Belo Horizonte, Ibirité, and Macacos quadrangles, Minas Gerais, Brazil

22. Analyses of sludge and core samples from the Mutuca diamond drill hole no. 1

23. Analyses of sludge and core smaples from the Mutuca diamond drill hole no. 2

24. Analyses of bauxite, Macacos quadrangle, Minas Gerais, Brazil. 


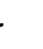


GEOLOGY AND MINERAL RESOURCES OF PARTS OF MINAS GERAIS, BRAZIL

\title{
GEOLOGY AND ORE DEPOSITS OF THE BELO HORIZONTE, IBIRITÉ, AND MACACOS QUADRANGLES, MINAS GERAIS, BRAZIL
}

\author{
By Joel B. Pomerene
}

\begin{abstract}
Deposits of high-grade hematite occur in Precambrian ironformation in the Quadrilatero Ferrifero, an area of about 7,000 square kilometers in central Minas Gerais, Brazil. The ironformation is part of a thick sequence of folded metasedimentary rocks surrounded by granite. The metasedimentary rocks in the Belo Horizonte, Ibirité, and Macacos quadrangles have been divided into two series: the lower, the Rio das Velhas, and the upper, the Minas. The Rio das Velhas series has been divided into two groups, the lower, the Nova Lima, and the upper, the Maquiné. Probably only the older group is present in the area considered in this report. The Minas series is divided into three groups; the lowest, the Caraça, is derived from clastic sediments; the middle, the Itabira, from dominantly chemical sediments, and the upper, the Piracicaba, from dominantly clastic and pyroclastic sediments. Each of the groups in the Minas series has been divided into two or more formations.
\end{abstract}

The Caraça group is composed of the Moeda formation consisting of quartzite, conglomerate and phyllite, and the overlying Batatal formation consisting of phyllite. The overlying Itabira group is composed of two formations, the Cauê itabirite below and the Gandarela above. The Cauê itabirite is dominantly a laminated oxide-facies iron-formation and contains all the principal iron deposits in the area. The Gandarela formation characteristically consists of dolomite and dolomitic itabirite, but also includes phyllite and quartzite. The disconformably overlying Piracicaba group is divided into five formations. The lowest, the Cercadinho formation, consists of quartzite, ferruginous quartzite, and phyllite. It is overlain by the Fecho do Funil formation of dolomitic phyllite, argillaceous dolomite, and phyllite. Stratigraphically above this is the Taboões quartzite consisting entirely of very fine grained quartzite. It is overlain by the Barreiro formation consisting of phyllite and graphitic phyllite. The uppermost unit of the Piracicaba group is the Sabará formation consisting of phyllite, quartzite, graywacke, and metavolcanics. Its top is not known because the upper part has been intruded by granite, and thick staurolitic schist has been formed by the intrusion.

Granitic rocks of at least four ages occur in the Quadrilátero Ferrifero as determined by $A \mathbf{r}^{40} / \mathbf{K}^{40}$ ratios in biotite. Two of these granites occur in the area of this report. One of these is about 1,300 million years old, the other about 500 million. The older granite is pre-Minas, but the younger granite is intrusive into upper Minas rocks and is therefore younger.

Gabbro and ultramafic rocks, now altered respectively to metagabbro and to talc schist and serpentinite, are intrusive into the Rio das Velhas series. Two or more granites, and diabase in the form of dikes have intruded both the Rio das Velhas and the Minas series. Quartz veins are common.

The Rio das Velhas series was deformed, and deeply eroded before deposition of the Minas series. After deposition of the Minas series, both series were folded and metamorphosed, during which time the major faults in the area probably were formed. Regional metamorphism exceeding the chlorite isograd is rare in these three quadrangles, but contact metamorphic zones of staurolite schist occur near intrusive granite.

The region was subjected to peneplanation that was terminated by regional uplift, probably in Tertiary or Quaternary time. Most of the rocks are deeply weathered and easily eroded, and so the rejuvenated streams have developed a youthful to mature topography. Alluvium of Tertiary and Quaternary age has in places been altered to clay and bauxite.

There are two major types of iron ore, bedrock hematite ore containing from 66 to 69 percent iron, and surficial ore containing 40 to 68 percent iron. The high-grade hematite ore occurs as replacement bodies in formations of the Itabira group-dominantly in the Cauê itabirite but to some extent in the Gandarela formation. The surficial ore is derived most commonly from these formations by weathering. The Caue itabirite averages about 40 percent iron and may be an important source of iron in the future.

The high-grade bedrock hematite ores range from hard, dense. and fine grained to fine, soft, and powdery. Most ore bodies exhibit both textures. The mean grain size in both textures is about 0.03 millimeter.

The ore bodies generally are 95 percent hematite. Minor amounts of magnetite, quartz, talc, pyrophyllite, phosphorusbearing minerals, and argillaceous material may be present.

The high-grade bedrock hematite ore is believed to have been formed by replacement of the quartz in itabirite by hematite leached from the surrounding itabirite.

Surficial iron ore deposits are divided into two major types: (1) the indurated iron-rich conglomerate known as canga; and (2) loose, unconsolidated iron-rich debris.

Reserves of high-grade hematite in the Belo Horizonte, Ibirité, and Macacos quadrangles are estimated to be 160 million metric tons of ore above the lowest outcrop or exploration and 400 million metric tons to a depth of 50 meters below the lowest exposures. Many ore bodies probably extend to a much greater depth than 50 meters, and so the total reserves may be several times this estimate.

Bauxite, clay, asbestos, and small amounts of manganese are also present in the area. 


\section{INTRODUCTION}

The geologic study of the Belo Horizonte, Ibirité, and Macacos quadrangles is part of a program of geologic mapping and investigation of the iron and manganese resources of the Quadrilátero Ferrífero (see fig. 1), an area of about 7,000 square kilometers, in central Minas Gerais, Brazil. This is a joint undertaking between the United States of Brazil and the United States of America. The study has been administered by the Brazilian Ministério da Agricultura and by the U.S. Department of State through the Institute of InterAmerican Affairs, first under the Technical Cooperation Administration, then under the Foreign Operations Administration, and lastly under the International Cooperation Administration. The Brazilian Departamento Nacional da Produção Mineral, Divisão do Fomento Mineral of the Ministério da Agricultura and the U.S. Geological Survey, Department of the
Interior, have been responsible for carrying on the work.

\section{LOCATION AND ACCESSIBILITY}

The three quadrangles of this report have a common corner, at latitude $20^{\circ} 00^{\prime} 00^{\prime \prime}$ south and longitude $44^{\circ} 00^{\prime} 00^{\prime \prime}$ west. This corner is approximately 11 kilometers $\mathrm{S} .35^{\circ} \mathrm{W}$. of the obelisk in the center of Praça Sete de Setembro, the official center of the city of Belo Horizonte. The Belo Horizonte quadrangle contains most of the city of Belo Horizonte, the capital of the State of Minas Gerais. The quadrangle is joined on the south by the Macacos quadrangle, which is joined on the west by the Ibirité.

The city of Belo Horizonte is 345 kilometers due north of Rio de Janeiro by air and is served by about 60 round-trip flights a week from Rio de Janeiro. The city is connected with Rio de Janeiro by the national highway, BR-3, a paved highway 452 kilometers long. Average driving time for passenger cars is about $81 / 2$

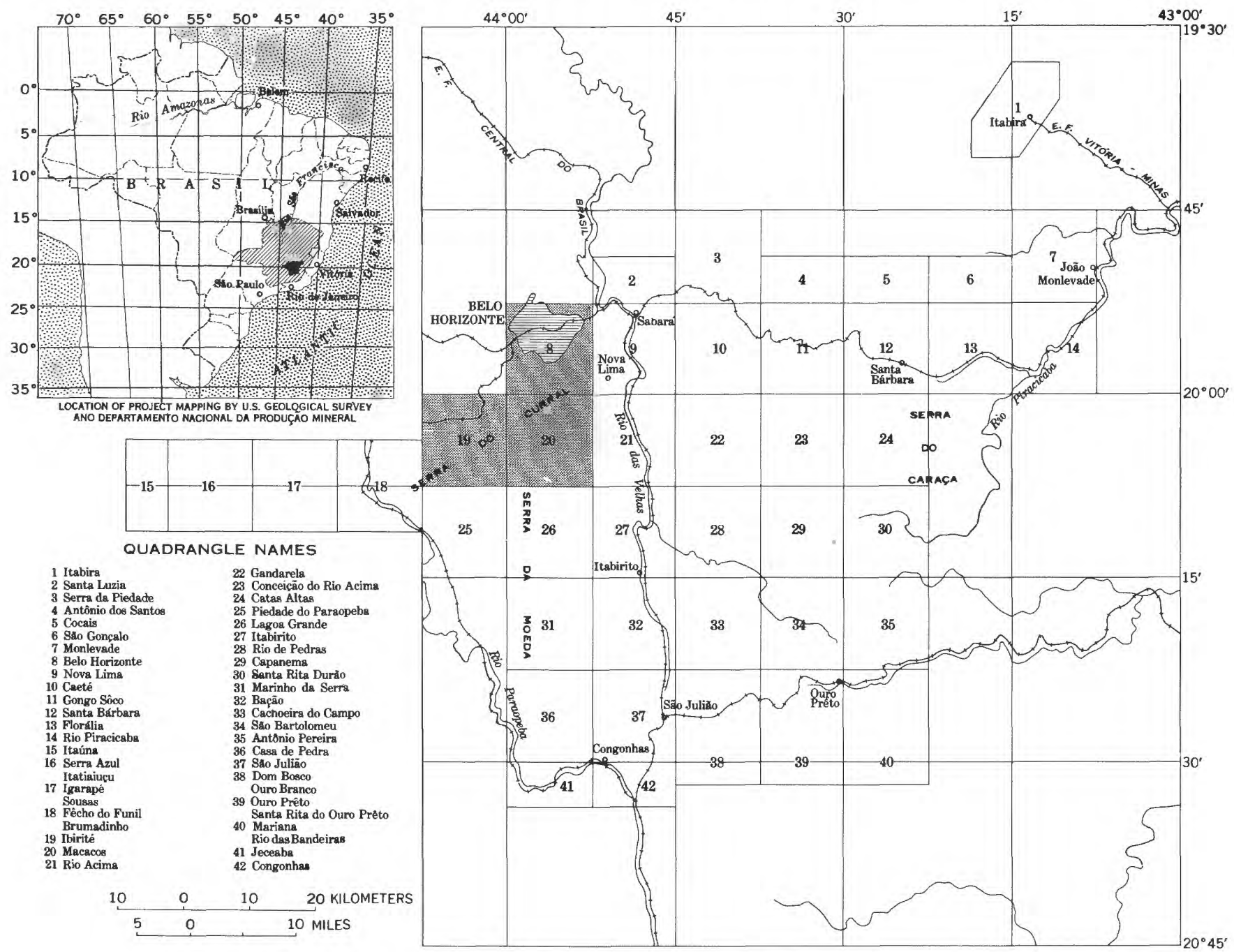

Figure 1.-Index map showing location of the Belo Horizonte, Macacos, and Ibirite quadrangles. 
hours. A broad gage railroad (1.60 meters), also, connects Belo Horizonte with Rio de Janeiro. From Belo Horizonte this railroad runs southwest through Ibirité and Brumadinho, and then south through Congonhas to Rio de Janeiro.

The city of Belo Horizonte was planned in the early 1890 's. After the site was chosen and detailed plans approved, surveyors laid out the principal streets and avenues, as well as the sites of important government buildings. The city was officially founded in 1897; in 1957 the city had a population of 482,000 , and was sixth in size in Brazil.

\section{PHYSIOGRAPHIC FEATURES}

Maximum relief in the three quadrangles is 780 meters, from a minimum elevation of 750 meters above sea level in the northeastern part of the Belo Horizonte quadrangle to 1,530 meters above sea level in the south central part of the Macacos quadrangle. Local relief generally is from 200 to 400 meters.

One of the most prominent physiographic features of the region is an east- to northeast-trending mountain range extending from the vicinity of Itauna to northeast of Caeté (see fig. 1), a distance of about 65 kilometers. South of Belo Horizonte this range is known as the Serra do Curral del Rei. To the southwest and west, the same range is successively called Serra da Mutuca, Serra da Rola Moça, Serra da Jangada, and Serra dos Tres Irmãos. This range trends somewhat north of east across the Ibirité quadrangle and crosses the Belo Horizonte quadrangle trending about N. $50^{\circ}$ E.

From the crest of Serra do Curral at an average elevation of 1,300 meters, the land slopes steeply northward, in both the Ibirité and Belo Horizonte quadrangles, to the relatively low lands underlain by granite gneiss where the relief generally is only 50 to 75 meters and slopes are gentle. It is on this gently rolling topography that the city of Belo Horizonte was built.

South of the Serra do Curral is a terrain of schists and phyllites that has been thoroughly dissected. The topography consists primarily of narrow divides and steep-walled valleys. Relief averages about 150 meters. This terrain continues into the northeastern half of the Macacos quadrangle.

The terrain south of the range in the Ibirite quadrangle is gently rolling and similar to that north of the range. The rock in this area is granite.

In the Macacos quadrangle, the outstanding physiographic feature is a north-trending high plateau, 1,300 to 1,500 meters above sea level. It has been protected from erosion and dissection by resistant beds of quartzite and itabirite on both sides of the large north-trending
Moeda syncline. The western limb of the syncline forms a prominent mountain range known as the Serra da Moeda. The eastern limb is not so prominent and geographic names are scarce or lacking. South of Macacos, this limb is known as the Serra do Itabirito, the name which will be used for this feature in the Macacos quadrangle.

Most of the area of these three quadrangles is drained by tributaries of the Rio das Velhas. The southern part of the Ibirité quadrangle, however, is drained by streams flowing westward into the Rio Paraopeba. All streams in the mapped area are small; discharge varies considerably between the dry and rainy seasons. In the southern part of the Macacos quadrangle, one of the headwater tributaries of the Rio do Peixe flows into a reservoir built by the St. John del Rey Mining Co. Water is drawn from the reservoir during the dry season to increase the volume of the Rio do Peixe in order to maintain adequate flow at the company's powerplants.

\section{CLIMATE AND VEGETATION}

The climate of the area is temperate. Uncomfortably warm nights are infrequent even in the warm season. In the cold season frost has been seen by the writer in higher parts of the Macacos quadrangle but frost is unknown in Belo Horizonte.

Rainfall ranges from 1,300 to 1,500 millimeters a year, most of it coming from December to May. The St. John del Rey Mining Co. has kept rainfall and temperature records for more than 100 years. Inasmuch as Nova Lima, where the recordings were made, is only a few kilometers southeast of Belo Horizonte, table 1 is offered to show temperatures and rainfall in the general area.

Forest once covered most of the area of these three quadrangles but woodcutting and subsequent annual burning of the brush and grass has prevented second growth in most places. Possibly some of the quartzite terrain was never heavily forested. Areas of Tertiary and Quaternary alluvium, which are flooded in the rainy season, are free of forest.

Most areas covered by canga ${ }^{1}$ are bare of forest, but in places a large tree is found growing on such material. This is reminiscent of the practice of some woodcutters of leaving an occasional tree for seed. It is possible that forest and soil may have been present on some ridges where now only bare canga is exposed.

\footnotetext{
1 Canga is a term applied to various hard ferruginous rocks, ranging from conglomerate of rich hard hematite cemented by a small percentage of limonite to limonitic "hardpan" of clay and iron-rich soil cemented by limonite.
} 
Alves of the DNPM and the writer worked together on mapping that part of the Belo Horizonte quadrangle outside the city of Belo Horizonte but the entire burden of mapping in the city fell upon Dr. Alves.

The U.S. Geological Survey party consisted of at least 12 geologists all of whom contributed to the solution of problems concerned with mapping the iron deposits. In many cases the answers to questions concerning the stratigraphy or structure were found in one quadrangle and were passed along to geologists working in other areas. J. V. N. Door II, chief of the field party, was the coordinator of this effort. The writer was accompanied in the field during the initial stages of the work and was made acquainted with local customs and the geology by Mr. Philip W. Guild, one of the first of the United States Geological Survey geologists to work in the iron bearing district of Brazil.

Thanks and appreciation are extended to the officers of the St. John del Rey Mining Co. without whose cooperation the study would have been most difficult. General managers Mr. George Weigel and his successors, Mr. A. L. Yarnell and Mr. H. C. Watson, were most cooperative and helpful. This company made available field living accommodations convenient to work areas and made available maps, chemical analyses, and precise survey data.

Dr. Iphygenio Soares Coelho, consulting geologist and professor of geology in the University of Minas Gerais, made housing available to the field party for several months during mapping of the Ibirite quadrangle, and had many polished sections of ores made at the University of Minas Gerais.

The writer's field assistant was João Sudario Lopes of DNPM who showed an unusual knowledge and understanding of the problems peculiar to fieldwork.

\section{GEOLOGY}

The Quadrilátero Ferrífero is a roughly rectangular area of Precambrian metasedimentary, metavolcanic, and granitic rocks, surrounded by younger granite gneiss of the Brazilian shield.

The metasedimentary rocks of the Quadrilatero Ferrifero have been divided, on the basis of major unconformities, into three series - the Rio das Velhas, the Minas, and the Itacolomi. The oldest of these, the Rio das Velhas series, consists dominantly of green schist and quartzite with minor beds of carbonate-facies ironformation and dolomite. The Minas series, unconformably overlying the Rio das Valhas, consists of quartzite, phyllite, itabirite, dolomite, and graywacke. The Itacolomi series, overlying the Minas with angular discordance, is dominantly quartzite and conglomerate.

Granite and granite gneiss of three ages intrude the Rio das Velhas series, and at least one granite rock in- trudes the Minas series. Detailed investigations of the relationship of granites to the Itacolomi series are not yet completed.

Ultramafic rocks now altered to serpentinite, talc schist, and soapstone have been intruded into the Rio das Valhas series. No clear evidence that ultramafic rocks have intruded the Minas series has been found in the area of these three quadrangles.

All three series have been intruded by diabase dikes. Quartz veins also are common in all three series.

All rocks of Precambrian age in the Quadralátero Ferrífero are metamorphic or igneous, but only locally does the metamorphic grade exceed the chlorite facies except in the vicinity of intrusive granite.

The general geology of the Quadrilátero Ferrífero including the Belo Horizonte, Ibirité, and Macacos quadrangles is shown in figure 2 .

The stratigraphic column of the Quadrilatero Ferrífero is shown in table 2.

\section{STRATIGRAPHY}

\section{RIO DAS VELHAS SERTES}

The rocks of the Rio das Valhas series were originally included in the Minas series as described by Derby (1906).

Rynearson, Pomerene, and Dorr (1954) recognized the significance of the profound unconformity in Derby's Minas series and noted the much greater degree of deformation of the underlying contorted schists and phyllites. Dorr and his colleagues (1957) proposed the name Rio das Velhas for this older series and at the same time proposed dividing it into two groups, the Nova Lima below, and the Maquiné above.

The Maquiné group was first named (Dorr and others, 1957) on the basis of mapping by O'Rouke (written communication) in the Gandarela and Rio das Pedras quadrangles. O'Rouke found an unconformity within the Rio das Velhas series, on the basis of which he divided the series into two groups, the upper of which is the Maquiné group. J. E. Gair (1962), in subsequent mapping of the Rio Acima and Nova Lima quadrangles, recognized the same unconformity and designated the rocks below it the Nova Lima group (Dorr and others, 1957).

No definite evidence was found to indicate the presence of the Maquiné group in the three quadrangles covered by this report.

\section{NOVA IIMA GROUP}

The Nova Lima group in the area consists dominantly of schists, phyllites, and metavolcanic rocks. Quartzite, dolomite, and carbonate-facies iron-formation are also present but comprise only a small part of the volume of the group. 


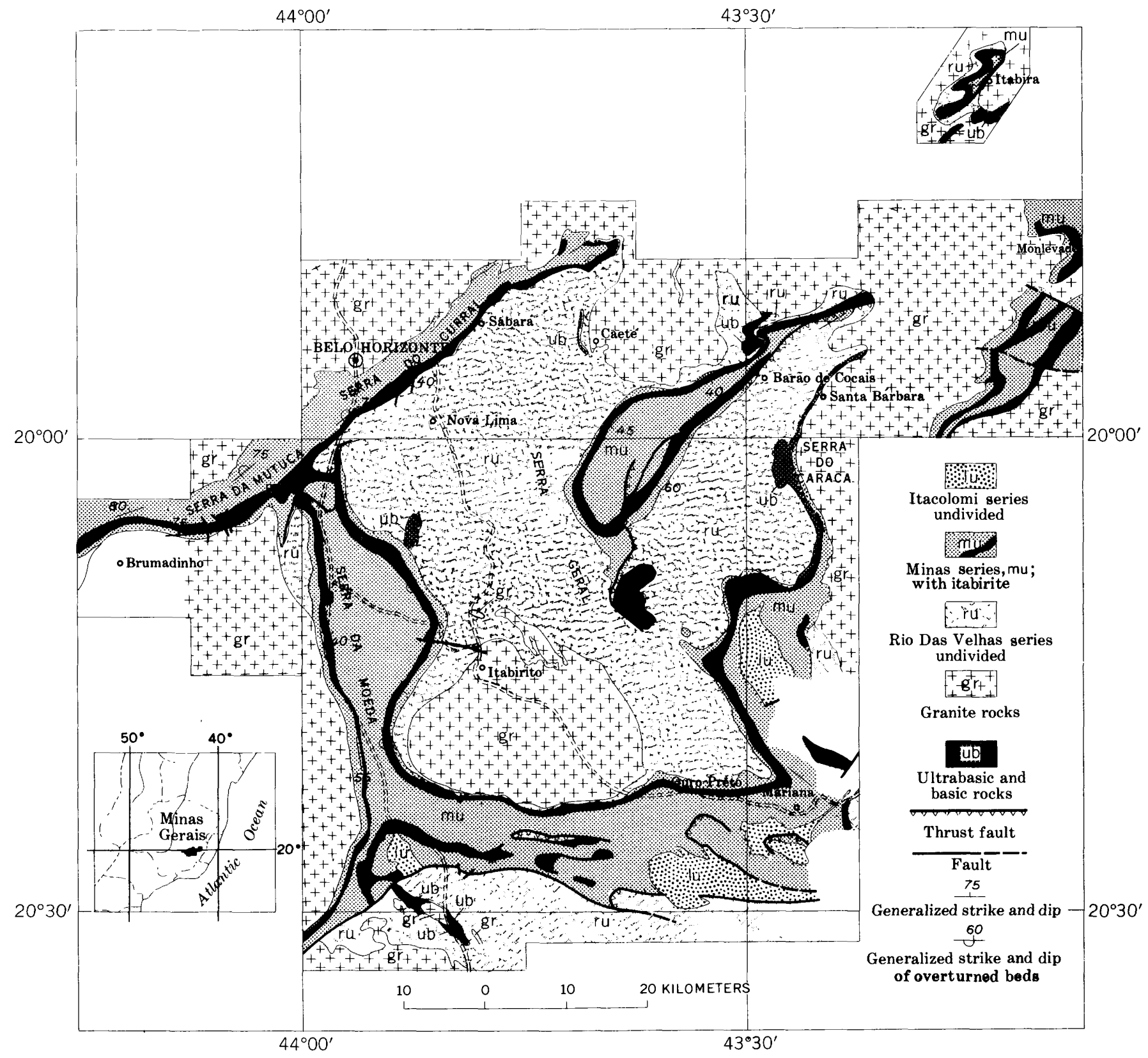

Figdre 2.-Geologic map of the Quadrilatero Ferrífero, Minas Gerais, Brazil. (Modified from geologic base by Herz.)

Metasedimentary rocks of this group are the oldest known in the area of this report; the lower contact is unknown. East of the Belo Horizonte and Macacos quadrangles the Nova Lima group is unconformably overlain in places by the Maquiné group, whereas in the three quadrangles covered by this report, the Nova Lima group, is unconformably overlain by the Caraça group of the Minas series.

No reliable estimate can be made of the stratigraphic thickness of the Nova Lima group from evidence found in the Belo Horizonte, Ibirité, and Macacos quadrangles. In the Macacos quadrangle alone, the width of
Nova Lima strata measured across the general strike is from 10,000 to 12,000 meters, and the measurement could be extended into the adjoining Rio Acima quadrangle. How much of this width is due to repetition of beds by folding and faulting, is unknown.

With the exception of the iron-formations and a conglomerate-phyllite-quartzite sequence, it was not feasible in the time available to map stratigraphic units in the Nova Lima group. The rocks are folded, crenulated, and faulted; exposures are few and weathering has so altered most of the units, except for small outcrops of graphitic phyllite, and of quartzite, that 
TABLE 2.-Stratigraphic column of the Quadrilatero Ferrifero, Minas Gerais, Brazil

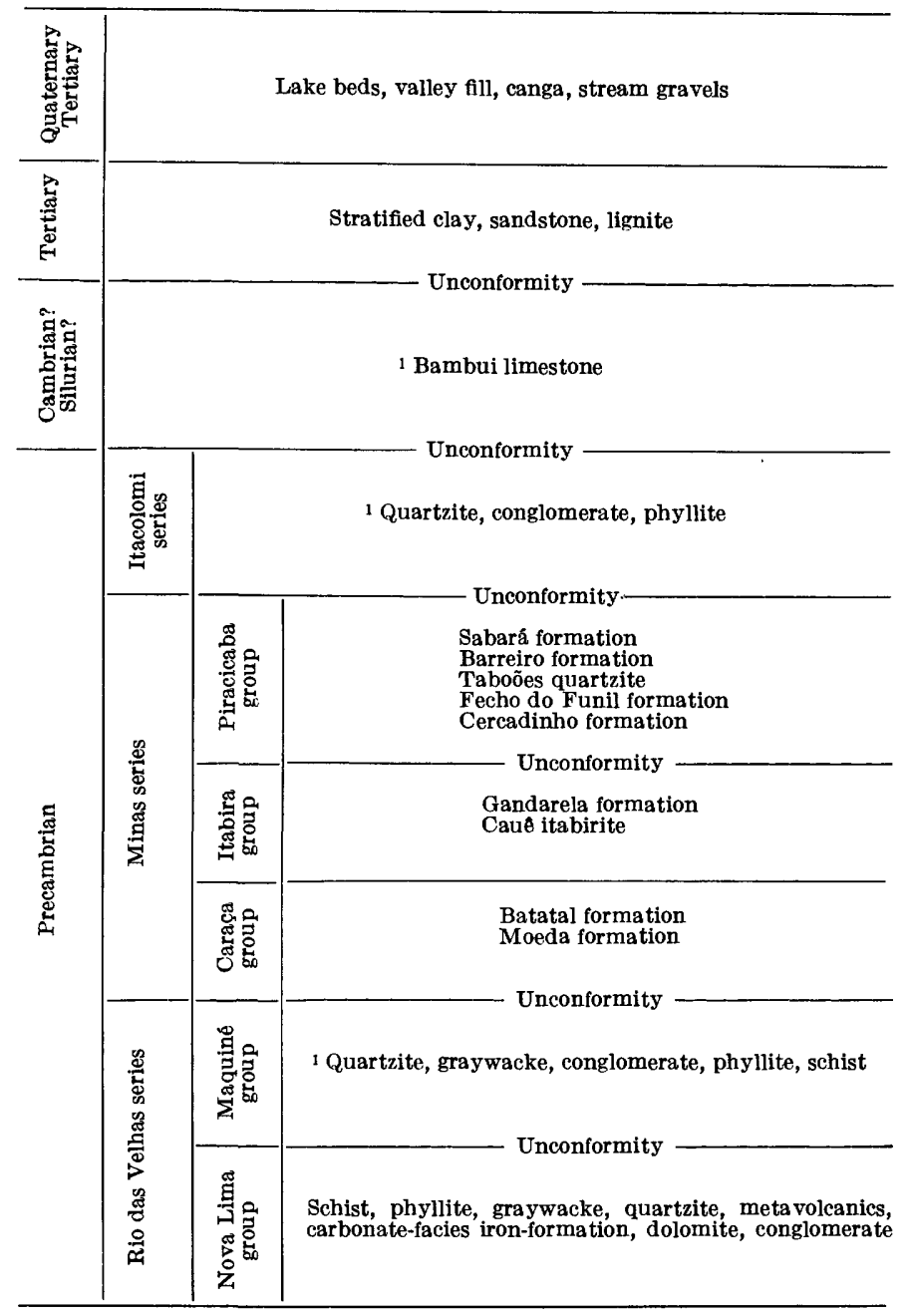

${ }^{1}$ Not present in the Belo Horizonte, Ibirité, or Macacos quadrangles.

they were noted only as pink, purple, or tan schist or "phyllite." No really fresh rocks of the Nova Lima group are exposed in these three quadrangles.

The only fresh samples the writer collected from the Nova Lima group were taken during mapping of the Gaia tunnel in the Rio Acima quadrangle. Thin sections of these samples were studied by J. E. Gair who found that metavolcanic schist is interbedded with sedimentary schist with which carbonate (ankeritic to sideritic) -magnetite-quartz iron-formation is also interbedded. Beds of graphitic rock are closely associated with the iron-formation.

\section{IRON-FORMA'TION OF THE NOVA LIMA GROUP}

At the surface, the iron-formation of the Nova Lima ranges from slightly ferruginous, crystallized chert with indistinct limonite bands, to a well-banded rock with alternating layers of friable hematite or magnetite, and white granular quartz. This latter type fits the definition of itabirite by Dorr and Barbosa (1963). The most common type of weathered iron-formation of the Nova Lima in this area is lithologically somewhere between these two extremes; it consists of well-banded and crystallized chert layers containing a mixture of iron oxides including limonite; locally it may consist entirely of limonite where strongly weathered.

In geologic investigations before the present detailed mapping program, this banded iron-formation was considered to be the equivalent of what is now called the Cauê itabirite in the overlying Minas series. Only when it was shown that the strata enclosing the iron-formation of the Nova Lima group were separated from the Minas series by a major unconformity (Rynearson and others, 1954) could it be stated definitely that the older iron-bearing units were not facies of what is now known as the Cauê itabirite.

Judging only from surface exposures, the thicker parts of the iron-formation of the Nova Lima can easily be mistaken for the younger Cauê itabirite. This is especially true if only one or two outcrops are examined, because the lithology of any given hand specimen from the older iron-formation can be closely matched from some part of the Cauê itabirite. Field recognition of the iron-formation of the Nova Lima depends not on the type of rock in one or two exposures but on the type of rock most common in many exposures along several kilometers of strike. Some differences in the most distinctive rock types of the two formations are as follows:

\begin{tabular}{l|l}
$\begin{array}{c}\text { Rock types common in iron-formation of the } \\
\text { Nova Lima but rare in Caue itabirite }\end{array}$ & $\begin{array}{c}\text { Rock types common in Caue itabirite } \\
\text { but rare in the Nova Lima group }\end{array}$ \\
\hline
\end{tabular}

1. Slightly ferruginous, crystallized chert, generally limonitic, with banding indistinct or absent.

2. Well-banded iron-formation consisting of layers of hard, dark limonite and layers of yellow-stained crystallized chert.
1. Alternating layers of specular hematite and of pinkish crystallized chert.

2. High-grade hematite ore, either hard or soft.
A well-banded rock consisting of alternating layers of iron oxide and sugary white quartz occurs both in the Nova Lima group and the Cauê itabirite. Generally, this rock in the Nova Lima group is somewhat less distinctly banded than that in the Cauê itabirite. Moreover, the iron oxide of the Nova Lima is more likely to be magnetite in contrast to the more common hematite of the Cauê itabirite.

The most extensive area of mappable iron-formation of the Nova Lima in the Quadrilatero Ferrifero is in the area of the common corner of the Belo Hori- 
zonte, Nova Lima, Macacos, and Rio Acima quadrangles. Other bands of such iron-formation occur in the Gandarela quadrangle, in the green schist area south of São Julião and Congonhas, in the Gongo Sôco quadrangle, and in the Itabira district.

In the area of this report, iron-formations of the Nova Lima are restricted to the southeast quarter of the Belo Horizonte quadrangle and to the eastern half of the Macacos quadrangle. Near the southeast corner of the Belo Horizonte quadrangle (pl. 1) two persistent, subparallel bands of iron-formation cross the eastern boundary of the quadrangle into the adjacent Nova Lima quadrangle. These two bands are on the limbs of a fold which has its nose in the Nova Lima quadrangle, about 2 kilometers east of the boundary. Whether this fold is anticlinal or synclinal could not be determined, as metamorphism and weathering have obliterated top and bottom criteria. Other smaller bands cannot be correlated with the folded bed, and probably are minor beds and lenses of iron-formation, some of which may be older and some younger than the major bed. The small band of iron-formation crossing the eastern boundary of the Belo Horizonte quadrangle at N. 2,000 ${ }^{2}$ apparently lenses out to the west as shown on the map.

One of the larger areas of iron-formation of the Nova Lima group is in the area where the southern limb of the fold loops south in the Belo Horizonte quadrangle, crosses the southern boundary of the quadrangle at E. 11,500, and extends about 400 meters into the Macacos quadrangle. (See pl. 2.) A thin but relatively persistent band enters the Macacos quadrangle from the east at N. 12,700 and strikes S. $40^{\circ} \mathrm{W}$. It can be traced, gradually thinning, for 3 kilometers before it lenses out. Where this bed crosses an east-west road, the rock is weathered and friable. Chemical analysis of a chip sample taken from the roadcut shows the following composition :
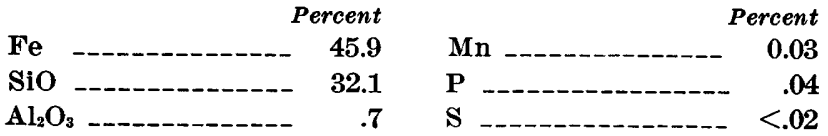

(Analyzed by Cássio Mendonça Pinto, Laboratorio do Departamento Nacional da Produção Mineral, Belo Horizonte, Boletim de Análise 2530.)

The sample was checked spectroscopically for nickel and cobalt by Claudio Dutra of the Instituto Tecnologia Industrial; only traces of these two elements were found.

\footnotetext{
2 Each quadrangle map bears an arbitrary grid system with the zero point at the southwest corner of each quadrangle. Tick marks, representing 1,000-meter intervals, appear along the bottom and along the left-hand edge of each quadrangle map. Text references to points on the map are usually followed by figures representing the distance in meters north and east of the southwest corner of the designated quadrangle.
}

The other occurrences of iron-formation of the Nova Lima group in the Macacos quadrangle are very thin lenses that persist for distances ranging from several meters to a few hundred meters. At N. 7,270, E. 10,700 a thin bed of well-banded iron-formation only 20 centimeters thick is exposed in a large outcrop of reddish phyllite.

Other small lenses of iron-formation occur at Maca$\cos$ N. 2,600, E. 11,700 and N. 4,750, E. 12,900 . The first is about 5 meters thick and the second is 1 meter thick. Several zones of iron formation rubble occur near the second lens, so it is likely that other small lenses are present.

These occurrences are worth noting because thin beds indicate that conditions suitable for the deposition of iron-formation occurred locally for short periods, many times before conditions became favorable for the deposition of the major iron-formation found in the unconformably overlying Minas series.

The thickness of the iron-formation is difficult to determine. Where units form bold ridges and good outcrops, the true thickness cannot be determined because isoclinal shear folding has increased the outcrop width many times. Where this has not occurred, the iron-formation forms poor outcrops and its presence is shown only by a line of rubble.

The width of the map pattern in areas such as at Belo Horizonte N. 2,200, E. 8,400 indicates the average amplitude of isoclinal shear folds. The axial planes of the folds are about at right angles to the trend of the iron-formations, and are roughly parallel to the regional foliation. In such areas the attitudes of the bedding and the attitudes of the axial planes are approximately the same, and very few of the strikes shown on the map reflect the general trend of the ironformation. The same is almost certainly true of the adjacent schist and phyllite.

Only one place was found (Belo Horizonte quadrangle N. 940, E. 8,660) where both contacts of one of the larger iron-formation beds could be located within 1 meter and where no evidence of thickening by folding was present.

The following section was measured from northeast to southwest directly across the strike :

\section{Meters Description}

1. 0-5 _-_-.. Crumbled and slumped tan phyllite.

2. 5-33 _...-. Iron-formation of the Nova Lima group consisting of alternating 7 -millimeter thick bands of yellowish-brown crystallized chert and dark-brown limonite.

3. 33-34 -.... Covered.

4. 34-38 -.... Igneous rock, soft and deeply weathered, medium yellowish-orange material. Original nature of rock unknown. 
The measured section of the iron-formation is 28 meters, which after correction for the $45^{\circ} \mathrm{dip}$, indicates an actual thickness of 20 meters. This measurement may not represent the maximum stratigraphic thickness because one of the contacts of the iron-formation is with igneous rock. Only if the igneous rock were a flow at the base of the formation would the measured section represent the true thickness.

Although the band of iron-formation entering the Macacos quadrange from the east at N. 12,700 is shown relatively straight on the map, it is probable that isoclinal folding has increased its outcrop width. Neither contact can be accurately located on the surface, and so the mapped width is based partly on topographic expression and partly on the width of the band of ironformation rubble. The iron-formation exposed in the road cut is less than 20 meters thick.

No unweathered iron-formation of the Nova Lima group is exposed in either the Belo Horizonte or the Macacos quadrangles; however, samples of fresh ironformation were collected by J. E. Gair and the writer from underground workings in the Nova Lima and Rio Acima quadrangles which adjoin the Belo Horizonte and Macacos quadrangles on the east. According to Gair (1962) the unweathered iron-formation is gray, dark gray, or light gray green and typically contains dominant quartz and iron-rich carbonate. In some places the unweathered iron-formation contains abundant magnetite. The quartzose layers are white or light colored, but the rock derives its dominant color from the carbonate or carbonate and magnetite. Gair found the carbonate generally sideritic, but ankerite or ferrodolomite in places.

Although Gair's samples came from an area that may have been somewhat altered by mineralizing fluids, it is considered that the effects of the alteration were minor and that these samples give a fair idea of the original rock type of all iron-formation of the Nova Lima group.

The limonite, so common on surface exposures of the iron-formation, is the result of weathering of the ironrich carbonate minerals. The limonite bands still contain magnetite grains and crystals in many places, and it appears that magnetite was unaffected by weathering and that little, if any, was altered to limonite. The great resistance of magnetite to weathering and alteration is also shown by the presence of magnetite crystals in silicified and limonitized dolomitic material of the Minas series. See discussion of ironstone (p. D20).

Goethite occurs as botryoidal crusts on some joint surfaces and botryoidal manganese oxide occurs on others. In some places the crusts of manganese oxide contain appreciable amounts of nickel and cobalt. Two samples of such material from joint faces in a small quarry in the southeast corner of the Belo Horizonte quadrangle (N. 100, E. 11,100) contained 2.0 percent and 1.4 percent cobalt and 3.5 percent and 1.0 percent nickel, respectively. These data are of academic interest only as it would be difficult to collect more than a few kilograms of the material.

Economically, the iron-formation of the Nova Lima in the Belo Horizonte and Macacos quadrangles has little value. The iron content is too low, especially considering the proximity of the larger volume of richer Cauê itabirite. The rocks are not goldbearing as in the quadrangles to the east.

The iron-formation is a source of easily accessible hard rock, which is rare in this region of deeply weathered schists and phyllites. A small amount of iron-formation has been quarried for use in foundations for houses, and for concrete aggregate for dams and powerline tower footings. Some of the iron-formation surface rubble could be used locally for road gravel.

\section{CONGLOMERATE-QUARTZITE SEQUENCE}

A sequence consisting of conglomerate, gray phyllite, and quartzite occurs in the northwest part of the Macacos quadrangle. It can be traced only a few kilometers, generally striking north-northeast but hooking. eastward at the south end of the belt. The sequence is covered to the southeast by a thrust block and is truncated on the north at the unconformable contact with the younger Minas series. The sequence is best exposed in road cuts in the vicinity of Macacos quadrangle N. 10,300 , E. 3,200 .

At the south end of the mapped belt, where the strike is eastward, the lower part of the conglomerate overlies red phyllite and consists entirely of well-rounded boulders of medium-grained quartzite, as much as 50 centimeters in diameter, in a phyllite matrix. (See fig. 3.) North of this area only pebble and cobble conglomerate is exposed. The included fragments, mostly well rounded, consist of white vein quartz, smoky quartz, quartzite, phyllite, schist, and argillaceous quartzite. The argillaceous quartzite may possibly represent granite or arkose, but the boulders are too strongly weathered for this to be determined. Fragments of schist and phyllite in the rock commonly are angular.

The conglomerate is overlain by sheared, light-gray phyllite. This in turn is overlain by medium-grained sericitic quartzite. Thin lenses and small masses of fuchsite schist occur in the quartzite, and one small mass of quartzite is bright green due to intergranular fuchsite. The quartzite in turn is overlain by phyllitic rocks indistinguishable from phyllitic rocks of the Nova Lima group. 


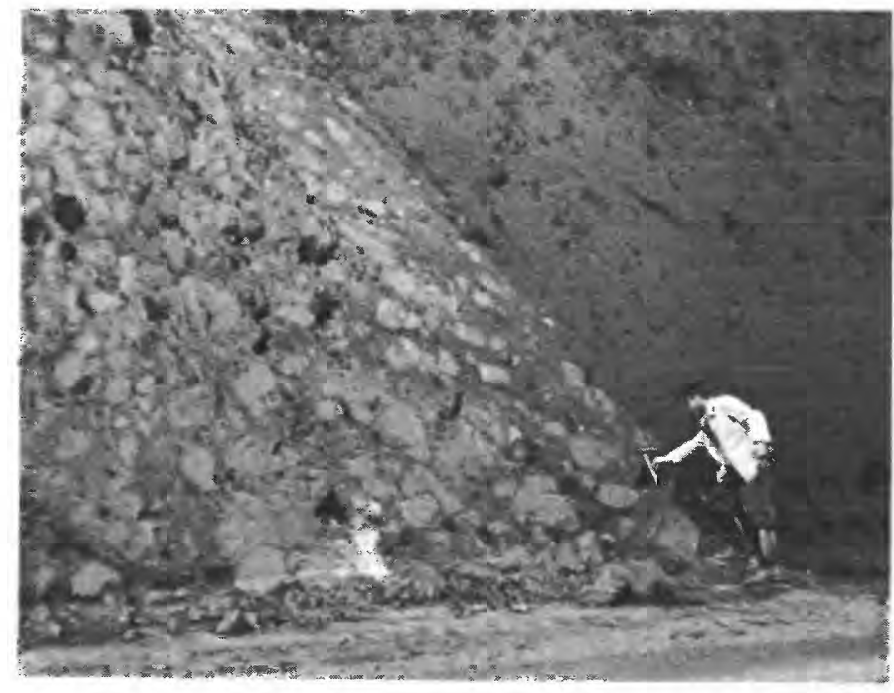

Frgore 3.-Boulder conglomerate stratigraphically orerlying red phyllite at $\mathrm{N}$. 10,200, E. 3,200, Macacos quadrangle. Both rocks are Rio das Velhas series.

Thicknesses of the sequence could not be determined but outcrop widths indicate that the rocks thin toward the north. Outcrop widths are as follows: conglomerate -20 to 500 meters; phyllite- 0 to 500 meters; and quartzite -20 to 200 meters.

The stratigraphic position of this sequence has not been established with certainty. The conglomerate may indicate disconformable relations with the underlying red phyllite. The material overlying the sequence seems to be typical of rocks of the Nova Lima group. On this basis, it would appear that the above described rocks lie below the top of the Nova Lima group.

Colleagues have suggested that the quartzitic parts of the sequence resemble the Maquiné group as mapped by O'Rourke (written communication) and Gair (1962). If this is the case, the lowest unit of the sequence should be a basal conglomerate. However, the presence of a thick section of phyllite of Nova Lima lithology above the quartzite rules out the correlation of these rocks with the Maquiné (see pl. 7, section D-D'. Nevertheless, the possibility exists that the sequence is equivalent to the Maquiné, in which case, it includes a thick lithologic unit not found in the type locality of that group.

Complex structures and a lack of outcrops in the northwest part of the Macacos quadrangle precludes solution of the problem at the present time.

\section{MINAS SERIES}

The Minas series is a thick sequence of quartzite, phyllite, itabirite, dolomite, graywacke, and metavolcanic rocks. This series is of great economic importance because it contains most of the deposits of iron and manganese in the Quadrilátero Ferrífero.
The series was defined and named by Derby (1906, p. 396-398). Harder and Chamberlin (1915, p. 341424) divided the Minas series into five formations: the Caraça quartzite, the Batatal schist, the Itabira ironformation, the Piracicaba formation, and the Itacolomi quartzite.

Dorr and others (1957) proposed dividing the Minas series into three groups: the Caraça, the Itabira, and the Piracicaba. These groups, in part, are equivalent to several of the formations named by Harder and Chamberlin. On the basis of the current quadrangle mapping by Departamento Nacional da Produção Mineral and the U.S. Geological Survey, each of the groups has been divided into formations (Symposium on the stratigraphy of the Minas series in the Quadrilátero Ferrífero, Minas Gerais, Brazil: Boletim da Sociedade Brasileira de Geologia, v. 7, p. 57-69, 1958).

The classification of sedimentary rocks into clastic and chemical sediments furnished the basis for the division of the Minas series into three groups. The lower group of rocks is dominantly clastic and is called the Caraça group because most of the group is Caraça quartzite as described by Harder and Chamberlin (1915). The Batatal schist of these authors also is included in this group, because it is a clastic rock.

The middle group of the Minas series consists dominantly of the chemically precipitated sediments, itabirite and dolomite. The name Itabira has been applied to this group because the group includes all of Harder and Chamberlin's Itabira formation as well as the overlying dolomite and dolomitic rocks.

The upper group consists dominantly of clastic rocks including quartzite, phyllite, graywacke, and metavolcanic rocks. It has been named the Piracicaba group (Dorr and others, 1957) as it includes most of the Piracicaba formation of Harder and Chamberlin.

The Minas series unconformably overlies rocks of the Rio das Velhas series in the Quadrilátero Ferrífero where it may rest on either the younger group of the Rio das Velhas series, the Maquiné, or on the older, the Nova Lima. In the area of this report, the Minas rests unconformably on the Nova Lima group. In most of the Ibirité quadrangle (see pl. 3) the Caraça group of the Minas is in contact with granite.

The Minas series is unconformably overlain by the Itacolomi series in parts of the Quadrilátero Ferrífero. In the area of this report, however, the Itacolomi series is not present. The upper part of the Minas series has been intruded by granite and is granitized.

\section{CARACA GROUP}

The Caraça group consists of conglomerate, quartzite, and phyllite. It can be divided, in the Belo Horizonte, Macacos, and Ibirité quadrangles, into the Moeda 
formation (Wallace, 1958) and the Batatal formation (Maxwell, 1958) which correspond to the Caraça quartzite and the Batatal schist of Harder and Chamberlin (1915).

The outcrop width of the Caraça group in the Ibirite quadrangle ranges from about 150 meters on the west side to about 1 kilometer in the east central part at the Rochedo das Gaivotas (N. 4,700, E. 10,800) where the trend of the outcrop has turned sharply south. The Caraça is offset northward by a major fault from where it trends southeasterly into the western limb of the Moeda syncline in the Macacos quadrangle (see fig. 2). Its stratigraphic thickness along this stretch ranges from about 400 to 800 meters. The outcrop width of 1,000 meters at Rochedo das Gaivotas may be due in part to thickening during deformation.

The Caraça group in the southeast corner of the Macacos quadrangle is part of the eastern limb of the Moeda syncline. Its outcrop width there is approximately 1,500 meters, and this relatively great width is probably due to repetition by folding and faulting. The outcrop of the Caraça on the east limb trends northward almost to the northern boundary of the quadrangle where it is offset by a major fault. The stratigraphic thickness in that area is about 200 meters. The offset portion of the Caraça group outcrop trends westward and then northeastward, and narrows to less than 100 meters at the place where it passes from the Macacos into the Belo Horizonte quadrangle.

The Caraça outcrop trends northeasterly across the Belo Horizonte quadrangle, where the stratigraphic thickness of the group ranges from about 100 meters to about 300 meters. Southeast of Aguas Claras (N. 5,100, E. 11,000) its outcrop width increases to about 750 meters. This increase in width, most apparent in the Batatal formation, may be due to a lesser dip of the beds.

MOEDA FORMATION

The lower part of the Caraça group previously known as the Caraça quartzite, has been defined by Wallace (1958) as the Moeda formation on the basis of excellent exposures on the western flank of the Serra da Moeda.

Wallace (1958) states that in the type locality, the Moeda formation can be divided into members, which he designated 1,2 , and 3 . In the three quadrangles described in this report, the Moeda formation can be divided into members only in the southwestern part of the Macacos quadrangle and in the south-central part of the Ibirité quadrangle.

In those parts of the mapped area where the Moeda formation is divisible, the lowermost unit, corresponding to member 1 as defined by Wallace (1958), consists of medium- to coarse-grained quartzite as much as 200 meters thick. Some of the beds are argillaceous and sericitic quartzite; others are relatively pure. The unconformable contact with the underlying Rio das Velhas series is marked in many places by lenticular beds of basal conglomerate, ranging in thickness from a few centimeters to more than 10 meters. Angular fragments of tan, maroon, and gray phyllite in the conglomerate are similar in lithology to the underlying Rio das Velhas rocks. The bulk of the conglomerate consists of rounded boulders, cobbles, and pebbles of smoky quartz, white vein quartz, and quartzite in a matrix of argillaceous quartzite.

Overlying the lowermost unit (member 1 ) is a member composed of siliceous light-gray to light-brown phyllite which grades along the strike into quartzsericite schist and very fine-grained quartzite. This unit corresponds to member 2 as defined by Wallace. It is overlain by medium- to coarse-grained quartzite (member 3) (Wallace, 1958), and contains lenses of conglomerate in many places. The conglomerate has very well rounded cobbles of smoky quartz in a matrix of medium- to coarse-grained quartzite.

On the east limb of the Moeda syncline in the Macacos quadrangle, near the Serra do Gama, the lower part of the Caraça group contains neither conglomerate nor phyllite and has not been divided into members. Aerial photographs show bands of outcrop and bands of grass-covered slopes, suggestive of quartzite and phyllite bands, but field traverses show that the outcrop bands are medium- and coarse-grained quartzite and the grass-covered bands are underlain by fine-grained quartzite. On the east limb in the central and northern part of the quadrangle, zones of conglomerate occur at the base of the group.

In the northwest part of the Macacos quadrangle, where Highway BR-3 is cut through the Serra de Mutuca, the Moeda formation is represented by only 3 meters of slightly conglomeratic quartzite. The thickness very gradually increases to the northeast across the Belo Horizonte quadrangle. For part of this distance, near Aguas Claras, the formation is concealed by soil and dense forest growth. East of the fault between Aguas Claras and Terra Branca, it has a greater stratigraphic thickness than elsewhere in the quadrangle. The quartzite near Terra Branca overlies a pebble and cobble conglomerate of the same type that occurs in member 1 of the formation in the Serra da Moeda. The conglomerate contains gold that may be of placer origin (see p. D79).

That the Moeda formation unconformably overlies rocks of the Rio das Velhas series on a regional basis was shown by Rynearson, Pomerene, and Dorr (1954). 
Subsequent mapping in the Belo Horizonte and Macacos quadrangles disclosed further evidence of the unconformity. In the southeast part of the Belo Horizonte quadrangle, iron-formation bands of the Nova Lima group trend northwest and north. They serve as marker beds showing the general trend of the Nova Lima rocks to be at angles of $45^{\circ}$ to $90^{\circ}$ to the trend of the Moeda formation.

Similarly the map pattern of the conglomeratequartzite sequence of the Rio das Velhas series in the northwestern part of the Macacos quadrangle shows an angular unconformity with the Moeda formation.

Two localities where the angular discordance between rocks of the Nova Lima group and the overlying Moeda formation can be seen clearly are at Macacos quadrangle N. 10,850, E. 4,400 and Macacos quadrangle N. 1,320, E. 520. At both localities, rocks of the Nova Lima group strike almost at right angles to the strike of the Moeda formation. The Nova Lima rocks can be traced to within a few meters of the Moeda formation in both exposures.

The Moeda formation is conformably overlain by phyllite of the Batatal formation.

BATATAL FORMATION

The Batatal formation (Harder and Chamberlin, 1915; Maxwell, 1958) generally consists of alternating light-gray and dark-gray laminae of phyllite each about 0.5 to 1 centimeter thick. The formation contains some thin beds of quartzite, dolomitic material, and ferruginous phyllite. The formation is deeply weathered and good outcrops are scarce. No unweathered Batatal formation is exposed in the area described in this report.

The Batatal formation overlies the uppermost quartzite bed of the Moeda formation and underlies the Cauê itabirite. In the Macacos quadrangle it is poorly exposed but the few available outcrops show it to be light-gray, dark-gray, and tan ferruginous phyllite. Fragments of the ferruginous phyllite in the soil in many places are the only indications of the extent of the Batatal formation. The Moeda formation is virtually nonferruginous and the Caue itabirite that overlies the Caraça group is virtually nonphyllitic. Ferruginous phyllite in the zone between the Moeda formation and the Cauê itabirite is mapped as Batatal formation.

Outcrop widths generally range from 100 to 200 meters in the Belo Horizonte and Ibirité quadrangles and from 100 to 500 meters in the Macacos quadrangle. Because the formation is generally steeply dipping, these figures give a fairly good indication of stratigraphic thickness, even though the outcrop is much wider in a few places because of low dip. In the Terra Branca area on the east side of the Belo Horizonte quadrangle, the Batatal formation appears as a belt about 500 meters wide. The writer attributes this relatively great width to a rotary fault which extends through a pass in the Serra do Curral and has tilted the eastern block to give the Batatal beds a relatively low dip.

Owing to scarcity of good exposures in these three quadrangles, little is known of the contact relations of the formation. Only two exposures of the upper contact have been seen, both in excavations. No exposures of the lower contact have been found.

One of the adits in a mine at Macacos (N. 13,600, E. 3,360) (see pl. 4, Adit 1) shows the contact of the Batatal formation with the overlying Cauê itabirite. The contact is so gradational that few geologists would agree as to which bedding plane divides the two formations. The Batatal formation is represented by alternating layers of ferruginous clay and hematiterich material; a gradational zone consists of sandy, ferruginous clay layers and layers of mixed earthy red and gray specular hematite. Rock probably representing the Cauê itabirite consists of alternating layers of red-stained quariz and red-stained hematite.

At Belo Horizonte N. 4,100, E. 8,250 the contact between the Batatal formation and the overlying Cauê itabirite is exposed in a road cut. The contact is gradational through a stratigraphic thickness of about 3 meters. The contact between the two formations was arbitrarily chosen in the gradational zone between banded hematite-quartz rock and banded hematiteclay material.

\section{ITABIRA GRODP}

The Itabira group consists dominantly of itabirite and dolomite derived from chemical sediments. The name Itabira formation was used by Harder and Chamberlin (1915) for the itabirite and included hard high-grade hematite and some dolomite. These rocks were elevated to group status (Dorr and others, 1957) to set them apart from the overlying and underlying clastic sedimentary rocks. The group is divided into two formations, the Cauê itabirite (Dorr, 1958, p. 6162 ) and the Gandarela formation (Dorr, 1958, 63-64).

\section{CAUE ITABIRITE}

The Cauê itabirite consists almost entirely of itabirite and hematite ore. The ore bodies, because of their economic importance, will be discussed separately. Throughout the Quadrilátero Ferrífero the Cauê itabirite stands as high ridges, commonly 400 to 600 meters above the lowlands. The itabirite, its chief lithologic component, is more resistant to erosion than other types 
of rock occurring in the metasedimentary and intrusive rocks of the region.

In the area of this report, the Cauê itabirite forms the crest of the Serra do Curral which trends east to northeast across the Ibirité and Belo Horizonte quadrangles. The Cauê forms also most of the higher ground along the flanks of the north-trending Moeda syncline in the Macacos quadrangle.

The stratigraphic thickness of the Cauê itabirite in the Belo Horizonte quadrangle ranges from about 100 meters in the southwest part to about 300 meters at Aguas Claras, about 5 kilometers southeast of Belo Horizonte. East of the fault between Aguas Claras and Terra Branca the outcrop width is much greater, possibly because of folding and faulting. The thickness is difficult to estimate in most of the Ibirite quadrangle, because the upper contact cannot be located accurately in the gradational zone between Caue itabirite and dolomitic itabirite of the Gandarela formation. The thickness of the steeply dipping Cauê itabirite on the south slope of the Serra da Jangada (Ibirité N. 4,700, E. 6,000 ) is 600 to 800 meters. (See pl. 7.)

In the Macacos quadrangle, on the limbs of the Moeda syncline, the Cauê itabirite ranges in outcrop width from about 700 meters to about 1,200 meters. The Cauê itabirite is much thinner in the part of the Serra do Curral that crosses the northwest corner of the Macacos quadrangle. There the outcrop width ranges from about 100 to about 400 meters.

The gradational lower contact of the Cauê itabirite is well exposed in only two places in these three quadrangles, as noted above in the section on the Batatal formation. The base of the Caue itabirite commonly is covered by canga and rubble of iron-formation. In some places a break in the otherwise even slope of the canga indicates the approximate location of the contact. This criterion was used to map the contact under the canga at Aguas Claras in the Belo Horizonte quadrangle. In other places, the contact can be located quite accurately by the contrast in color of soil. Soil derived from the itabirite most comonly is red and contains fragments and grains of hematite; soil derived from the Batatal phyllite generally is pale tan. Even where the contact is covered by detritus from the Cauê itabirite commonly there is evidence of the type of underlying rock from the color of soil particles in ant hills.

The Cauê itabirite commonly grades into dolomitic itabirite of the overlying Gandarela formation through a zone that may be 5 to 100 meters thick. In the Ibirité and Macacos quadrangles, exposures of fresh dolomite of the Gandarela formation are scarce. The only place in the Ibirite quadrangle where the upper contact of the Cauê itabirite can be accurately determined is in a deep road cut on the north slope of the Serra da Jangada. The contact is between soft itabirite and brown "splash" rock (Guild, 1957, p. 42-43), the latter derived from impure dolomite by thorough weathering and leaching. Elsewhere, in both the Ibirite and Macacos quadrangles, the location of the contact is indefinite. Along the north side of the Serra do Curral in the Belo Horizonte quadrangle the upper contact of the Cauê itabirite can be mapped with a probable error of less than 50 meters.

In defining the contact between the Cauê itabirite and the Gandarela formation, Dorr (1958, p. 61-64) proposed that the contact be drawn where the normal siliceous itabirite of the Cauê becomes subordinate to dolomitic itabirite or dolomite, considering the sedimentary section as a whole. This definition seems to be as good a one as possible, even though theoretically it would require a completely exposed section of the Itabira group.

The Cauê itabirite consists dominantly of banded, quartz-iron oxide rock known as itabirite. The definition of itabirite used herein is that given by Dorr and Barbosa, 1963) who define it as "a laminated, metamorphosed, oxide-facies iron formation in which the original chert or jasper bands have been recrystallized into granular quartz, and in which the iron is present as hematite, magnetite, or martite." They further restrict itabirite to material containing between 25 percent and 66 percent iron. Below 25 percent iron the rock is considered to be ferruginous crystallized chert; above 66 percent iron the rock is high-grade hematite.

Typical itabirite consists of alternating black and white laminae, each 5 to 10 millimeters thick. Although the thickness of the laminae actually ranges widely, one is impressed with a general appearance of even bedding. The separation of quartz and iron oxide is quite distinct even though a small amount of iron oxide commonly is disseminated in the quartz laminae, and some quartz is present in the laminae of iron oxide. The contacts between laminae are gradational over a fraction of a millimeter.

The grain sizes in the itabirite of the area of this report range from about 0.01 to 0.06 millimeter. In general the quartz occurs in slightly larger grains than does the hematite. The average grain size of the quartz is about 0.04 millimeter; that of the hematite is about 0.03 millimeter.

Almost everywhere in these three quadrangles, the dominant iron oxide mineral in itabirite is specular hematite. Even though the rock in many surface exposures of itabirite is magnetic, hematite is still the dominant iron mineral. The magnetic quality seems to be the result of weathering or possibly of reduction 
by sunlight, because magnetic itabirite is rare under ground.

Most itabirite is black and white, but locally small amounts of limonite color the rock brown. Itabirite in some surface exposures and some very shallow mine workings is red, presumably due to the partial breakdown of specular hematite grains into red earthy hematite. Some hard itabirite consists of layers of specular hematite and pinkish quartz. The pink color is due to extremely finely divided, disseminated hematite.

Itabirite at the crest of the main ridge in the western part of the Ibirite quadrangle consists of alternating layers of hematite or magnetite and felted mats of limonite. The limonite apparently is pseudomorphous after an unidentified amphibole. No unweathered rock of this type has been found in these three quadrangles, but west of this area similar itabirite has been found containing fresh amphibole, as yet unidentified (George Simmons, oral communication).

"Argillaceous" itabirite is common in the Serra do Curral, both at Águas Claras and in that part of the Serra do Curral known as the Serra da Mutuca. The medium-brown color of this rock is attributed to finely divided red to brown oxides and hydroxides of iron in the quartz layers. The rock appears dominantly clayey and seems to be only low-grade iron-formation. However, analyses of samples from the Mannesmann adits (see pl.4) reveal an iron content of about 60 percent and only a minor amount of $\mathrm{Al}_{2} \mathrm{O}_{3}$. Much of the material that looks like clay is finely divided hematite and limonite. Thus, the term "argillaceous itabirite" on the mine maps accompanying this report refers to appearance and texture-not to mineralogical composition unless supported by analyses showing high $\mathrm{Al}_{2} \mathrm{O}_{3}$.

Near the contact between the Caue itabirite and the Gandarela formation, the quartz and hematite in the itabirite may not be well separated into distinct layers, and the indistinct bands are considerably varied in thickness and in color. A 20-centimeter section of the material was measured and logged by the millimeter at the north end of tunnel no. 2 at Águas Claras (Belo Horizonte N. 5,850, E. 10,600). It clearly shows the differences in thickness, color, and composition of individual lamina in this zone of the Cauê itabirite.

Log of 20 centimeters of itabirite at the north end of the No. 2 tunnel at Aguas Claras, Serra do Curral

\section{Millimeters \\ $0-7$}

$7-10$

Quartz, white, powdery.

Description of laminae tends down dip for 40 centimeters, below which is white powdery quartz.

$10-65$ Rock, manganiferous, dark-brown to black ("black splash" as defined under the Gandarela formation).
Log of 20 centimeters of itabirite at the north end of the No. 2 tunnel at Aguas Claras, Serra do Curral-Continued
Millimeters Description of laminae
65-72_... Hematite, hard, specular.
72-83__._. Quartz, tan, powdery.
83-95_-_- Quartz, slightly pinkish, powdery. This layer changes into three layers a few centimeters up or down dip from the section. The center is pink powdery quartz; the bottom is ferrugi- nous, dark-brown powdery quartz; the upper is hard siliceous hematite.
95-105_-_- Quartz, white powdery; slightly grayer than that between $0-7 \mathrm{~mm}$.
105-115_-_ Quartz, dark-gray hematitic powdery.
115-118_-_ Quartz, light-brown, powdery.
118-120_-_ Quartz, hematitic, powdery.
120-125_._ Quartz, ocherous, powdery.
125-137_... Hematite, hard.
137-151__- Quartz, dark-brown, powdery.
151-155_._. Hematite, hard.
155-167__ _ Quartz, ocherous-brown, powdery.
167-168_- Hematite, hard.
168-169_-_ Quartz, white, powdery.
169-176__- Hematite, hard.
176-183_-_ Quartz, tan, powdery.
183-190__- Quartz, powdery; anastomosing veinlets and powdery hematite.
190-200___ Quartz, ocherous, powdery.

Although the typical siliceous Cauê itabirite forms ridges, it nevertheless disintegrates in places into several types of weathered rock. It commonly is capped by canga derived from underlying or nearby itabirite.

Three major types of siliceous itabirite can be distinguished on the basis of their degree of disintegration:

1. Hard itabirite in which both iron oxide and quartz layers are hard and firmly bonded.

2. Chapinha in which the quartz layers have disintegrated into quartz sand, and the platy fragments of hematite remain hard and coherent. (See fig. 4.)

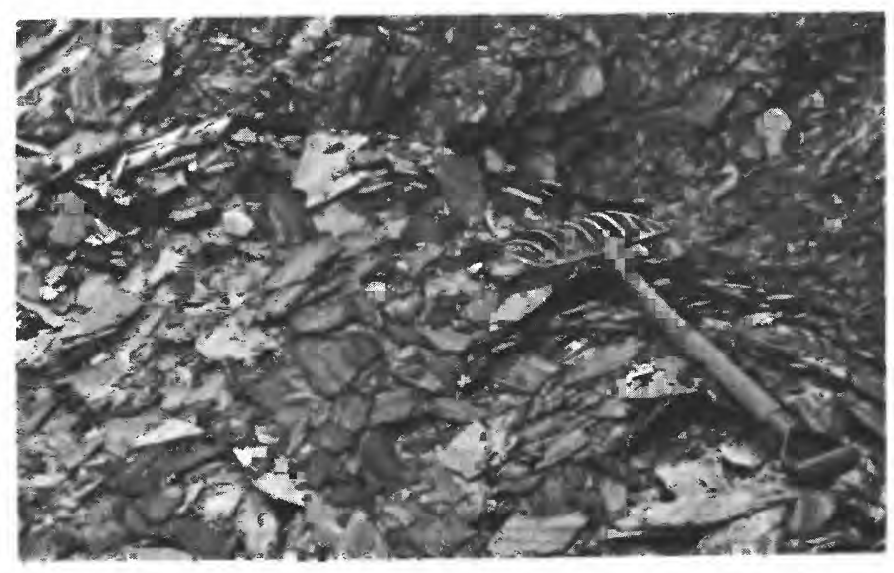

Ergure 4.-Plates of chapinha after most of the quartz has been removed by screening. 
3. Soft itabirite, in which both the iron oxide and the quartz layers are disintegrated into sand.

\section{GANDARELA FORMATION}

The Gandarela formation in the Belo Horizonte, Ibirité, and Macacos quadrangles consist of dolomite, magnesian limestone, and dolomitic itabirite. Schist, phyllite, and quartzite also are present in the formation in other quadrangles in the Quadrilátero Ferrífero (Rynearson, oral communication; O'Rourke, written communication; Johnson, 1962). These rocks may also be present although not exposed in Gandarela terrain in the quadrangles described in this report.

Harder and Chamberlin (1915, p. 362) apparently included the dolomitic rocks, now assigned to the Gandarela formation, in the lower part of their Piracicaba formation, when they described the lower beds of the Piracicaba as including "quite extensive lenses, and more or less irregular beds of quartz sand, iron oxide, and also calcium carbonate deposits."

During the early stages of mapping the Belo Horizonte quadrangle, the dolomitic rocks were mapped as a distinct member of what was then called the Itabira formation. O'Rourke later demonstrated in the Gandarela quadrangle that the unit could be classed as a formation (O'Rourke, written communication, 1954).

The Gandarela formation is present in most of the Quadrilátero Ferrífero although in the eastern part it is somewhat discontinuous. In several places it cannot be mapped separately from the Cauê itabirite because the only exposed rock is weathered dolomitic itabirite, which is difficult to distinguish from weathered Cauê itabirite. In the Belo Horizonte quadrangle the Gandarela formation is a well-defined unit; in the Ibirité and Macacos quadrangles, the contact between the Gandarela formation and the Cauê itabirite is commonly indefinite.

The maximum outcrop width of the Gandarela formation in the Belo Horizonte quadrangle is about 900 meters near the southwest corner of the quadrangle. The true stratigraphic thickness is about 400 meters, measured at Acaba Mundo (Belo Horizonte N. 4,200, E. 7,850), in about the middle of the quadrangle where the formation is most widely exposed.

In the Ibirité quadrangle, roughly the north half of the outcrop width of the Itabira group has been assigned to the Gandarela formation, based on a break in slope and on one exposure of the contact. In the Macacos quadrangle the mapped width of the formation ranges from a maximum of 1,900 meters on the eastern limb to a minimum of 500 meters on the western limb of the Moeda syncline. The stratigraphic thickness in the latter area is estimated to be about 500 meters.
The Gandarela formation is gradational into the underlying Cauê itabirite. The thickness of the gradational zone is nowhere less than 5 meters in the area of the report and it may be as much as 100 meters in the Ibirite quadrangle. The upper contact of the Gandarela formation is a surface of disconformity but, as the evidence of this is contained in the overlying Cercadinho formation, it will be described later in the report.

Fresh, hard dolomite in the Gandarela formation is exposed in several places along the north side of the Serra do Curral in the Belo Horizonte quadrangle but is sparsely exposed elsewhere in the area of this report. In the Macacos quadrangle fresh dolomite crops out at only two localities, both where streams have cut from 50 to 150 meters below the general upland surface.

One series of dolomite exposures is in Feixos, the deeply eroded area in the west-central part of the Macacos quadrangle; the other is along the Rio do Peixe below the dam of Lagôa Miguelão in the southcentral part of the quadrangle. In the Ibirité quadrangle fresh dolomite is even scarcer; the only known outcrops are near Ibirité N. 9,150, E. 10,900.

O'Rourke believed that at the type locality of the formation in the Gandarela quadrangle, the formation could be separated into three zones or members on the basis of color (O'Rourke, written communication, 1954). Dolomite of three colors is present in the Belo Horizonte quadrangle, but the colors are not restricted to zones in the formation and consequently furnish no basis for division into members.

In the three quadrangles of this report, only the area around Acaba Mundo in the Belo Horizonte quadrangle contains adequate exposures to permit measurement of a stratigraphic section of the Gandarela formation; even here the section is overturned and incomplete. The stratigraphically uppermost beds are covered by soil but are estimated to be 130 meters thick. The beds below (from 130 to 187 meters) are exposed in a vertical quarry face at N. 4,150 and E. 7,700, and therefore the thicknesses in that part of the section also are estimated. The lower part of the section, from 187 to 403 meters, was measured on outcrops, about 100 meters east of the quarry, extending uphill (but down section) to the base of the Gandarela formation in contact with Cauê itabirite.

Composite section of the Gandarela formation, Acaba Mundo area, Belo Horizonte quadrangle

\begin{tabular}{|c|c|}
\hline $\begin{array}{l}\text { Thickness } \\
\text { (Meters) }\end{array}$ & Description \\
\hline $0-130 \ldots$ & Covered. \\
\hline $130-152$ & Dolomite, greenish-gray and light-gray. \\
\hline $152-160_{-}$ & Dolomite, medium-gray. \\
\hline $\begin{array}{l}160-165 \\
165-167\end{array}$ & $\begin{array}{l}\text { Dolomite, grayish-purple; with veinlets of talc. } \\
\text { Covered. }\end{array}$ \\
\hline
\end{tabular}


Composite section of the Gandarela formation, Acaba Mundo area, Belo Horizonte quadrangle-Continued

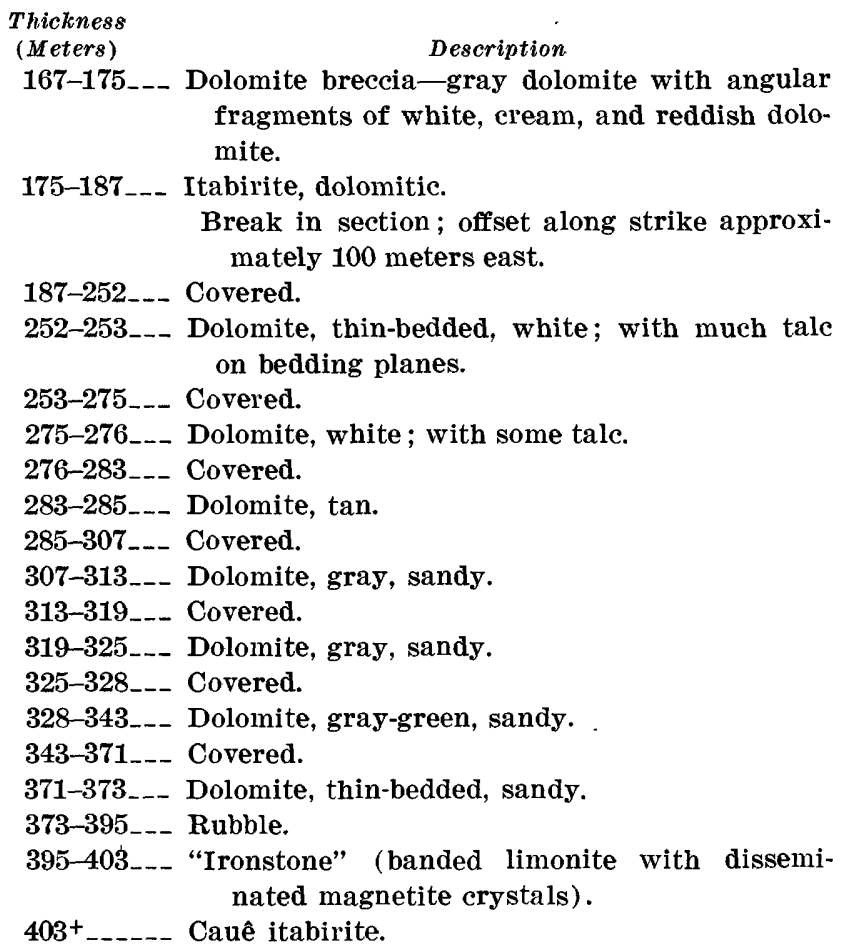

The only dolomite being quarried commercially in these three quadrangles is the pale-tan to creamy-white dolomite in the Acaba Mundo area. It is used by Magnesita $\mathbf{S}$. A. in the manufacture of refractory furnace linings. The company kindly furnished an analysis of the calcined product, which has been recomputed to a standard rock analysis as shown in table 3, column 1.

About 100 meters south of this quarry is a cliff of dark-red dolomite, on which some quarrying has been done in the past, apparently for exploration and sampling. An analysis of this rock was furnished by Magnesita S. A. and is reproduced in table 3, column 2.

Very ferruginous dolomite of this type is undoubtedly the parent rock of leached powdery material consisting of over 75 percent hematite; it was mistaken several times for soft ore of the Cauê itabirite during the early stages of mapping this area. Calculation shows that leaching of all the carbonate from a rock of the composition shown in table 3 , column 2 , will result in a product of over 75 percent $\mathrm{Fe}_{2} \mathrm{O}_{3}$.

Some beds in the Gandarela formation are almost pure hematite. A red dolomite outcrop at Acaba Mundo contains two major dolomitic itabirite beds with minor lenses of almost pure hematite, and one major bed of hard hematite which grades westward into dolomitic itabirite within about 100 meters along the strike. (See fig. 5.) This hematite breaks into
TABLE 3.-Analyses of dolomite, Belo Horizonte and Macacos quadrangles, Minas Gerais, Brazil

\begin{tabular}{|c|c|c|c|c|}
\hline & 1 & 2 & 3 & 4 \\
\hline $\begin{array}{l}\mathrm{CaO} \\
\mathrm{MgO} \\
\mathrm{MnO} \\
\mathrm{FeO} \\
\mathrm{Fe}_{2} \mathrm{O}_{3} \\
\mathrm{Al}_{2} \mathrm{O}_{32} \\
\mathrm{SiO}_{2} \\
\mathrm{Loss} \text { on ignition }\end{array}$ & $\begin{array}{r}29.23 \\
119.12 \\
(2) \\
(2) \\
3.18 \\
.46 \\
2.18 \\
43.92\end{array}$ & $\begin{array}{r}21.4 \\
116.6 \\
(2) \\
(2) \\
22.3 \\
.9 \\
5.2 \\
33.6\end{array}$ & $\begin{array}{r}29.34 \\
17.45 \\
.92 \\
3.97 \\
(2) \\
.4 \\
2.82 \\
44.50\end{array}$ & $\begin{array}{r}28.8 \\
23.2 \\
(2) \\
(2) \\
6.0 \\
4.2 \\
36.2\end{array}$ \\
\hline Total & 98.09 & 100.0 & 99.04 & 98.4 \\
\hline
\end{tabular}

1 Obtained by difference.

2 Not determined

Sample 1. White dolomite from Acaba Mundo, Belo Horizonte quadrangle; analvsis furnished by Magnesita S. A. recalculated from analysis of calcined products. 2. Red dolomite

2. sis furnished by Magnesita S. A.

3. Creamy white dolomite from Feixos, Macacos quadrangle. Analysis

4. furnished by St. John del Rey Mining Co. Macacos quadrangle. Analysis by St. John del Rey Mining Co.

rhombohedral blocks when mined, as shown in figure 6. The lower contact between hard hematite and weathered dolomite is knife-edged with no gradational zone. The contact is exposed in a trench to a depth of about 1 meter; through this distance the contact is conformable with the bedding and shows no reentrants of hematite into the dolomite.

The mean grain size of this hematite in a polished section is about 0.01 millimeter. The material is relatively porous; the pores range in diameter from about 0.1 to 0.04 millimeter. A few of the larger pores contain single quartz grains. The pores have no preferred alinement and give no suggestion of banding, so the presence of the quartz does not necessarily lead to the conclusion that the hematite has replaced itabirite. The origin of this hematite in the dolomite is not known. It could be a replacement of either dolomite or dolomitic itabirite. Conceivably it also could be due to original deposition, even though most other hematite bodies in the area show evidence of a replacement origin.

The high iron content of the red dolomite is probably primary, but hematite veinlets and local concentrations of hematite have been produced by considerable migration of iron within the rock. In one small fold with an amplitude of about 15 centimeters, ferruginous red dolomite forms the limbs up to a point about 2 centimeters below the crest of the fold. There the dolomite becomes noticeably more hematitic through a gradational zone of about 0.5 centimeter; the crest of the fold is composed of blue-gray hematite.

Specular hematite in veinlets is probably derived from the enclosing rock, but it may be purely of hydrothermal origin. Some evidence in support of the latter hypothesis is furnished by copper minerals that occur sparsely as crusts and veinlets in the red dolo- 


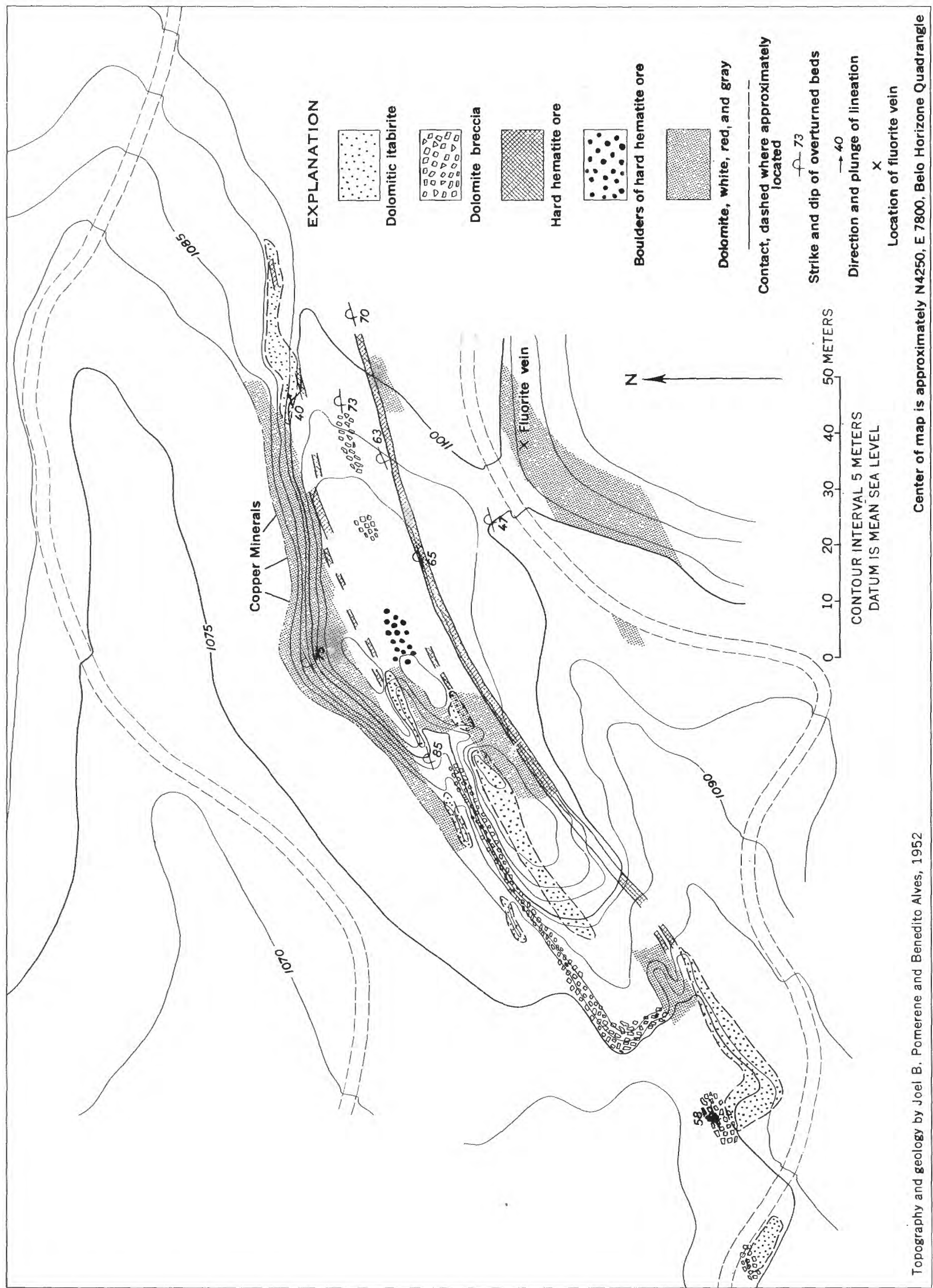




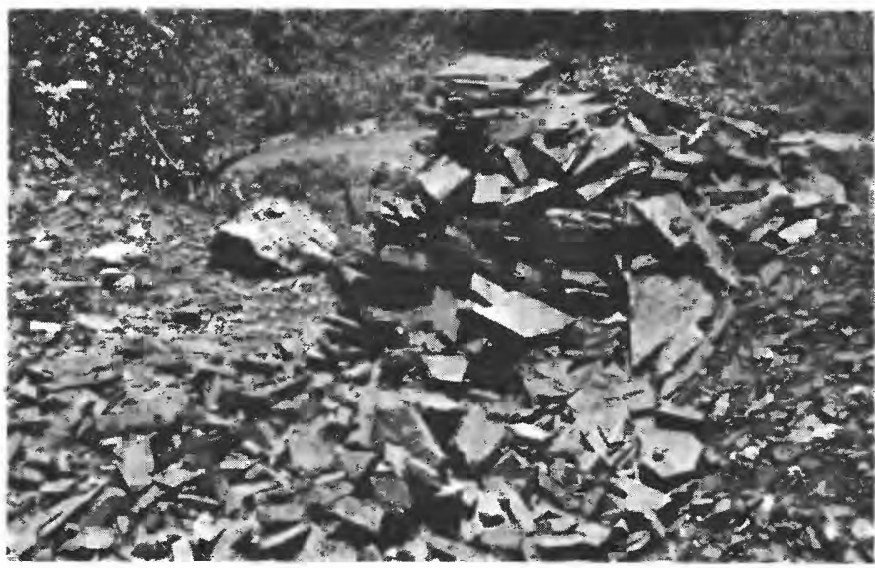

FrgurE 6.-Rhombohedral blocks of hematite from the Gandarela formation.

mite. Among the copper minerals present, malachite, azurite, and chalcopyrite have been recognized. Both the copper-bearing veinlets and the hematite veinlets are too irregular to determine whether there are one or two vein systems. Copper minerals and hematite have not been found together in any given veinlet, so it seems probably that the veinlets are of different ages.

The dolomite exposed south of the southern road (fig. 5) contains a number of gash fractures filled with quartz and calcite. Purple fluorite occurs with quartz and calcite in the largest gash fractures (fig. 7) but no fluorite was found in the smaller veins.

Although the dolomite thus has been affected by at least two types of mineralizing solutions, no evidence has been found that definitely connects the formation of the hematite beds either to the deposition of copper minerals, or of calcite and fluorite.

Other dolomite exposures along the north side of the Serra do Curral have been quarried in the past, but the quarries are inoperative at present and no production data are available.

In the Macacos quadrangle, the largest outcrops of dolomite are in deep gullies and ravines in the Feixos area, in the west-central part of the quadrangle. Much of the exposed dolomite is highly siliceous owing to included granular quartz and closely spaced anastomosing quartz veinlets. Some dolomite in the western part of the Feixos area is highly ferruginous but is known only from surface showings of manganiferous hematite powder. Dolomite from one of the more promising exposures was analyzed by the St. John del Rey Mining Co. for possible use in refractories (table 3, column 3 ). The analysis indicates that the rock is quite similar to that being quarried at Acaba Mundo (table 3, analysis no 1 ), but the Feixos area is so inaccessible that the

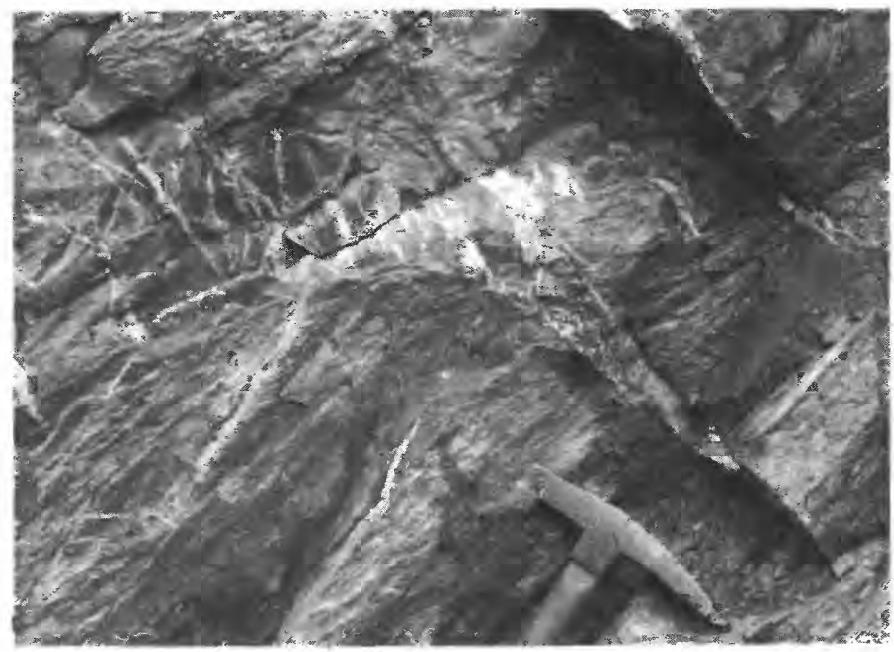

Figure 7.-Fluorite-bearing vein in dolomite at Acaba Mundo.

cost of building a truck road to the dolomite exposure would be prohibitive at present.

North-northwest of Feixos, at N. 7,970, E. 1,970, a diamond-drill hole was put down by the Departamento Nacional da Produção Mineral in the Quaternary and Tertiary alluvium in order to determine whether or not bauxite was present under the canga. The drill encountered dolomite bedrock at a depth of about 102 meters. Analysis of the dolomite drill core was made by the St. John del Rey Mining Co. (table 3, column 4).

Several poorly exposed outcrops of dolomite occur in the canyon of the Rio do Peixe. Both siliceous creamy-white dolomite and very ferruginous and siliceous red dolomite are exposed. Both rocks have been weathered, with surface leaching of carbonate, so that the quartz and hematite grains stand out in relief. It was not possible to obtain samples representative of the unweathered rock.

The dolomite exposed at Ibirité N. 9,150, E. 10,900 is gray to pale greenish gray. Beds from 1 to 5 centimeters thick are separated by thin layers of white to green talc. The rock splits easily into slabs; cross fractures limit the size of the slabs to pieces ranging from 10 or 20 centimeters in length. The exposures are small, and as nearby gullies crossing the strike of the dolomite show only weathered material, it is not likely that very much hard, fresh dolomite is readily available for quarrying.

Most of the dolomite of the Gandarela formation has been mapped by recognition of its weathering products and only a relatively small amount has been mapped on the basis of fresh outcrops. Some of these weathering products are valuable or potentially valuable deposits of ocher and manganese. Other materials attributed to the weathering of dolomite are "brown 
splash rock" and "black splash rock." These field terms will be described and used in this report for lack of formal petrographic terms for such material.

"Brown splash rock" is a product of weathering dolomite. P. W. Guild (1957, p. 42-43) and the author first recognized this relationship while mapping in the São Julião quadrangle. Inweathered banded graygreen dolomite having weathered zones extending down into it is exposed in a railroad cut directly opposite Usina station. The banding continues from the fresh dolomite into the weathered material without interruption or distortion. The weathered material appears only slightly damp but a sharp blow of the hammer results in a splash of water. A piece, squeezed in the hand, will resist a surprising amount of pressure and still keep its shape. As the pressure is increased, a point is reached where the material abruptly fails, leaving a muddy puddle in the hand.

Splash rock is highly cellular and when dry has a specific gravity considerably less than 1.00. Splash rock which has once been dried disintegrates rapidly when remoistened. It is composed principally of silica, limonite, and manganese and clay minerals.

Black splash rock is a manganese-rich variety in which the cell walls are manganiferous as well as limonitic. The hammer and the squeeze tests give the same results as with brown splash rock.

Meteoric water can dissolve the carbonate from a dolomite containing only 1 percent $\mathrm{MnO}$ and produce black splash rock with an appreciable manganese content. Pale-red dolomite from the Old Burnier manganese mine area, in the São Julião quadrangle, a rock which had been traced into splash rock, was analyzed by Edmir Elias Veiga of the Instituto de Tecnologia Industrial de Minas Gerais. The analysis is shown below :
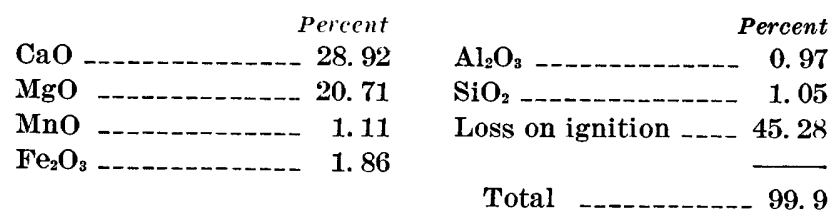

Assuming the removal of all the calcium and magnesium carbonate, the remaining oxides will constitute the entire rock. If 100 grams of the original sample were used for analysis, the sample, after leaching of all the carbonate, would weigh about 5 grams.

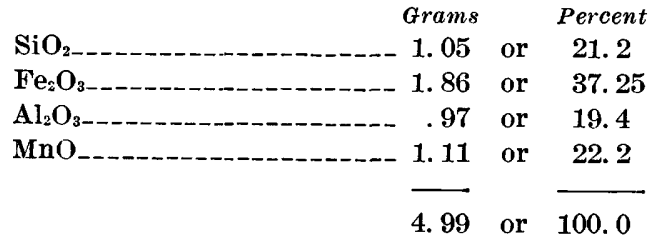

It is obvious that black splash rock with a high manganese content can be formed through leaching of a dolomite containing a very small amount of manganese. Further concentration by ground water, or introduction of more manganese could result in the formation of a high-grade manganese ore.

Fragments of black splash rock retain their shape during normal drying, but disintegrate rapidly when rewetted. Thoroughly dry black splash rock placed in water immediately begins to effervesce violently and then crumbles. It is surmised that water is drawn into the material by capillary action much more rapidly than the air within can be displaced, consequently the air is slightly compressed. The internal pressure is evidently sufficient to break the structure of the splash rock.

Outcrops of black splash rock are not common except in artificial exposures and in stream courses where the material is always damp. It is relatively resistant to erosion and exists even in the beds of streams with swift currents. It is apparent that black splash rock which has never been dried and thus has its cellular structure intact is little affected even by large volumes of water.

Another significant type of rock in the Gandarela formation is dolomitic itabirite. This is a laminated rock in which layers of hematite, magnetite, or both, with a small amount of admixed carbonate, alternate with layers of mixed carbonate and quartz. Only in very few places is the rock free of appreciable amounts of quartz.

Exposures of fresh dolomitic itabirite are scarce and the total volume is relatively small. However, the rock in many of these outcrops can be traced into weathered and leached alternating layers of friable iron oxide and ocher-stained, friable quartz. This product of weathering is common and locally may comprise a large part of the Gandarela formation. Relatively thin zones of similar material are found in the Cauê itabirite.

Leached and otherwise weathered dolomitic itabirite, itabirite, and ocher are well exposed in a tunnel through the Serra da Rola Moça in the Ibirité quadrangle at N. 8,000 , E. 10,800 . Plate 5 shows plan and section of the tunnel, with geologic notes and sketches by P. W. Guild. Samples were taken by the writer.

In the middle of the tunnel, 510 meters from either portal and 200 meters below the surface, the rock consists of both hard and soft limonitic itabirite. This is one of the deepest exposures of rocks of the Itabira group in the Quadrilátero Ferrífero, and even at 200 $\mathrm{m}$ from the surface the rocks are both limonitized and softened. 
Weathered dolomitic itabirite seems to grade along the strike into yellow ocher. This suggests that the ocher might be an end product of intense weathering of dolomitic itabirite.

Ocherous itabirite, probably derived from dolomitic itabirite, occurs on the north side of the Serra do Curral near the chapinha mine (Belo Horizonte N. 3,450, E. 6,750) at Lagõa Seca. (See table 4.)

A rock which may best be designated by the field term, "ironstone," was found in several places on Gandarela terrain in the Belo Horizonte quadrangle. A large section of this material is exposed in a quarry on Fazenda Conde at Belo Horizonte N. 700, E. 4,300. It is a dense, hard, siliceous limonite which breaks with a flinty, almost conchoidal fracture. It is coarsely banded, with bands from 1 to 3 centimeters thick in some of which are disseminated magnetite crystals. This type of banding is similar to banding commonly seen in some of the fresh dolomite and in "splash rock," and disseminated magnetite is common in many beds of fresh dolomite. It seems possible that ironstone is silicified and limonitized brown splash rock.

Much of the Gandarela formation in the Serra da Rola Moça in the Ibirité quadrangle is similar to the ironstone. The rock consists of bands of siliceous limonite and bands of hematite that are wholly or partly altered to limonite. Thin sections show that tiny octahedra of magnetite are scattered through the bands of altered hematite.

TABLE 4.-Analyses of ocherous itabirite representing about 75 meters of section near Lagõa Seca, Belo Horizonte quadrangle N3450, E6750.

Analyses by Cassio Mendonça Pinto, Laboratorio do Departamento Nacional da Produção Mineral, Belo Horizonte]

\begin{tabular}{|c|c|c|c|c|c|c|c|}
\hline & $\mathrm{SiO}_{2}$ & $\mathrm{Fe}$ & $\mathrm{Al}_{2} \mathrm{O}_{3}$ & Mn & $P$ & $\mathrm{H}_{2} \mathrm{O}+$ & Total 1 \\
\hline $\begin{array}{l}1 \\
2-1 \\
3 \\
4 \\
4 \\
5 \\
6\end{array}$ & $\begin{aligned} 15.3 \\
13.4 \\
8.0 \\
17.2 \\
17.3 \\
61.6 \\
11.8\end{aligned}$ & $\begin{array}{l}55.5 \\
56.1 \\
54.5 \\
51.5 \\
51.3 \\
61.3 \\
57.9\end{array}$ & $\begin{array}{l}1.7 \\
2.3 \\
2.4 \\
2.4 \\
1.6 \\
1.2 \\
1.7\end{array}$ & $\begin{array}{r}0.01 \\
.04 \\
.05 \\
.03 \\
.03 \\
.07 \\
.02\end{array}$ & $\begin{array}{l}0.04 \\
.06 \\
.05 \\
.05 \\
.04 \\
.05 \\
.05\end{array}$ & $\begin{array}{l}3.7 \\
4.1 \\
4.4 \\
6.8 \\
8.0 \\
4.5 \\
4.0\end{array}$ & $\begin{array}{r}100.1 \\
100.0 \\
99.9 \\
100.1 \\
100.3 \\
100.1 \\
100.3\end{array}$ \\
\hline
\end{tabular}

${ }_{1}$ Obtained by recalculating all iron in the form of $\mathrm{Fe}_{2} \mathrm{O}_{3}$.

A sample of this rock was taken from a roadcut on the north flank of the Serra da Rola Moça in the northeastern part of the Ibirite quadrangle. Chemical analysis ${ }^{1}$ revealed the following:
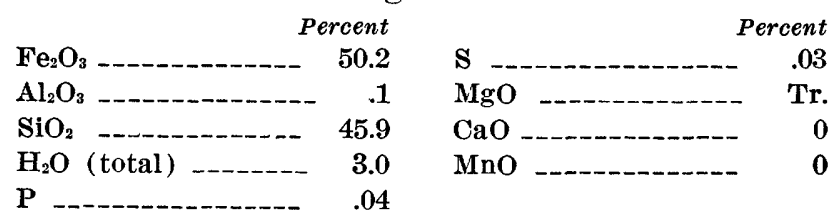

1 Boletim do análise No. 13486-Departamento Nacional de Produção Mineral, Rio de Janeiro; Analyst, Aida Espinola.
OF PARTS OF MINAS GERAIS, BRAZIL

PIRACICABA GROUP

The Piracicaba group consists of quartzite, phyllite, graywacke, and metavolcanic rocks and was originally described as a formation by Harder and Chamberlin (1915). Some of the lower beds of their formation are now included in the underlying Itabira group as defined in the present studies in the Quadrilátero Ferrífero. Dorr and others (1957) raised the Piracicaba from formation to group status so as to allow the description and naming of five lithologic units within it.

In the three quadrangles of this report, the upper part of the Piracicaba group is intruded by granitic rock and in places, is granitized and the true thickness cannot be determined. In other areas, as near Ouro Preto, the Piracicaba group is unconformably overlain by the Itacolomi series.

The maximum thickness exposed in these three quadrangles is about 4,500 meters.

\section{CERCADINHO FORMATION}

The name Cercadinho formation was proposed (Pomerene, 1958) for the sequence of strata of diverse lithology including quartzite, ferruginous quartzite, silver-colored phyllite, and tan, gray, and reddish phyllite that occurs immediately above the base of the Piracicaba group throughout most of the Quadrilátero Ferrifero. The bulk of the formation consists of tan and gray phyllite that has been deeply weathered and crops out in only a few places. The type locality is Morro Cercadinho near Cercadinho creek, at Belo Horizonte N. 2,700, E. 4,300, where the formation is 317 meters thick. At this place, the formation lies disconformably on slightly to moderately eroded rocks of the Gandarela formation. The basal beds of the Cercadinho commonly are a highly ferruginous, granuleto cobble-conglomerate. Its upper limit is defined as the top of the uppermost quartzite bed or the top of the uppermost bed of silver-colored phyllite. It is overlain by dolomitic phyllite, phyllitic dolomite, and phyllite. The characteristic lithologies which set this formation apart from others in the Piracicaba group are (1) highly ferruginous, granule-to cobble-conglomerate, (2) ferruginous quartzite, and (3) silver- or aluminum-colored phyllite.

The section at the type locality of the Cercadinho is shown in plate 6 ; it should be noted that the sequence is overturned in that area. The formation ranges widely in thickness; at a point only 3 kilometers from Morro Cercadinho, the formation is only 80 meters thick (fig. 8). Differences in thicknesses are indicated roughly by outcrop width in the Ibirité and Belo Horizonte quadrangles. 


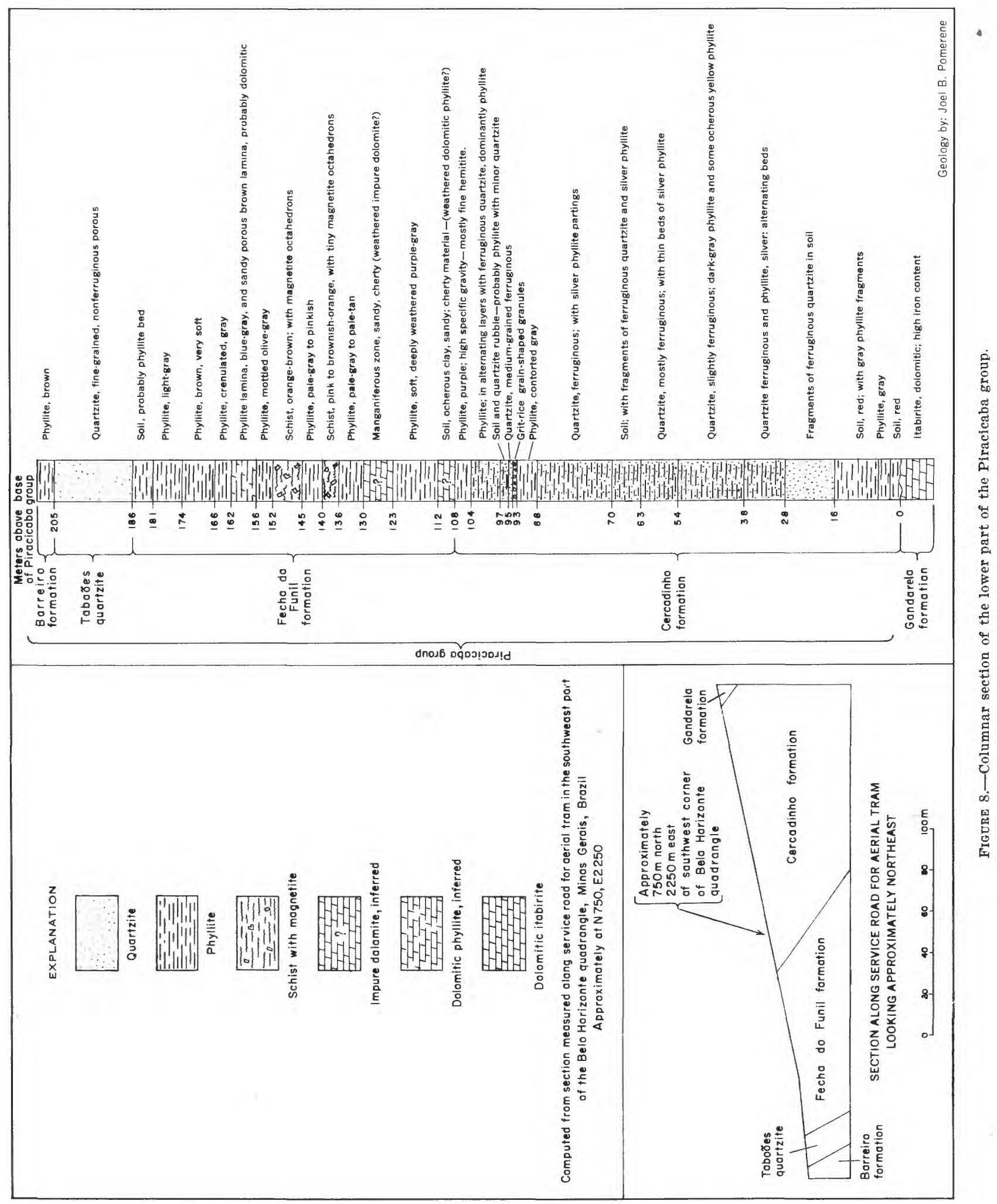


Individual beds from widely separated areas cannot be correlated because of their lenticular nature. The two sections shown in figure 8 and on plate 6 demonstrate that lithologic variation is in itself one of the characteristics of the formation.

The composition of the basal conglomerate of the Cercadinho is not everywhere the same. Immediately northeast of Morro Cercadinho there is an outcrop of conglomerate consisting of angular fragments of very fine-grained pink sandstone in a matrix of mediumgrained, gray quartzite. These fragments are similar to crystallized chert or to the very siliceous dolomite of the Gandarela formation. This type of conglomerate occurs at the base of the Cercadinho formation at several places in the three quadrangles.

Basal conglomerate, very close to the northwest corner of the Macacos quadrangle at N. 13,200, E. 700 contains well-rounded pebbles of white quartz, 1 to 3 centimeters in diameter, in a matrix of medium-grained, brownish quartzite. In the south-central part of the Belo Horizonte quadrangle at N. 4,070, E. 6,900, a conglomerate with small angular fragments of hematite occurs in the Cercadinho along the contact with the Gandarela formation. In the Belo Horizonte quadrangle at N. 5,000,
E. 8,000 , Cercadinho grit contains ellipsoidal concretions, 1 to 4 centimeters in length. The concretions are composed of hard blue hematite, have concentric structure, and typically contain a quartz pebble as a nucleus. Quartz grains and tiny octahedrons of magnetite are scattered through the hematite layers (see fig. 9).

Immediately above the basal conglomerate is a nonferruginous quartzite. When fresh, this quartzite is either white or pale grayish green; the white variety is all quartz, the greenish variety contains in addition to the quartz, appreciable amounts of chlorite and pyrite. The gray-green quartzite first weathers to a dark-brown and then lightens to a pale tan. The white quartzite does not change color during weathering, but after prolonged weathering loses its vitreous appearance, becomes porous, and approaches the appearance of a sandstone.

The white quartzite was originally a mediumgrained, equigranular sandstone with well-rounded, almost spherical grains. Under the microscope the quartz grains can be recognized because they contain many tiny inclusions. These contrast with the clear secondary quartz cement that has grown in optical continuity with each original grain.

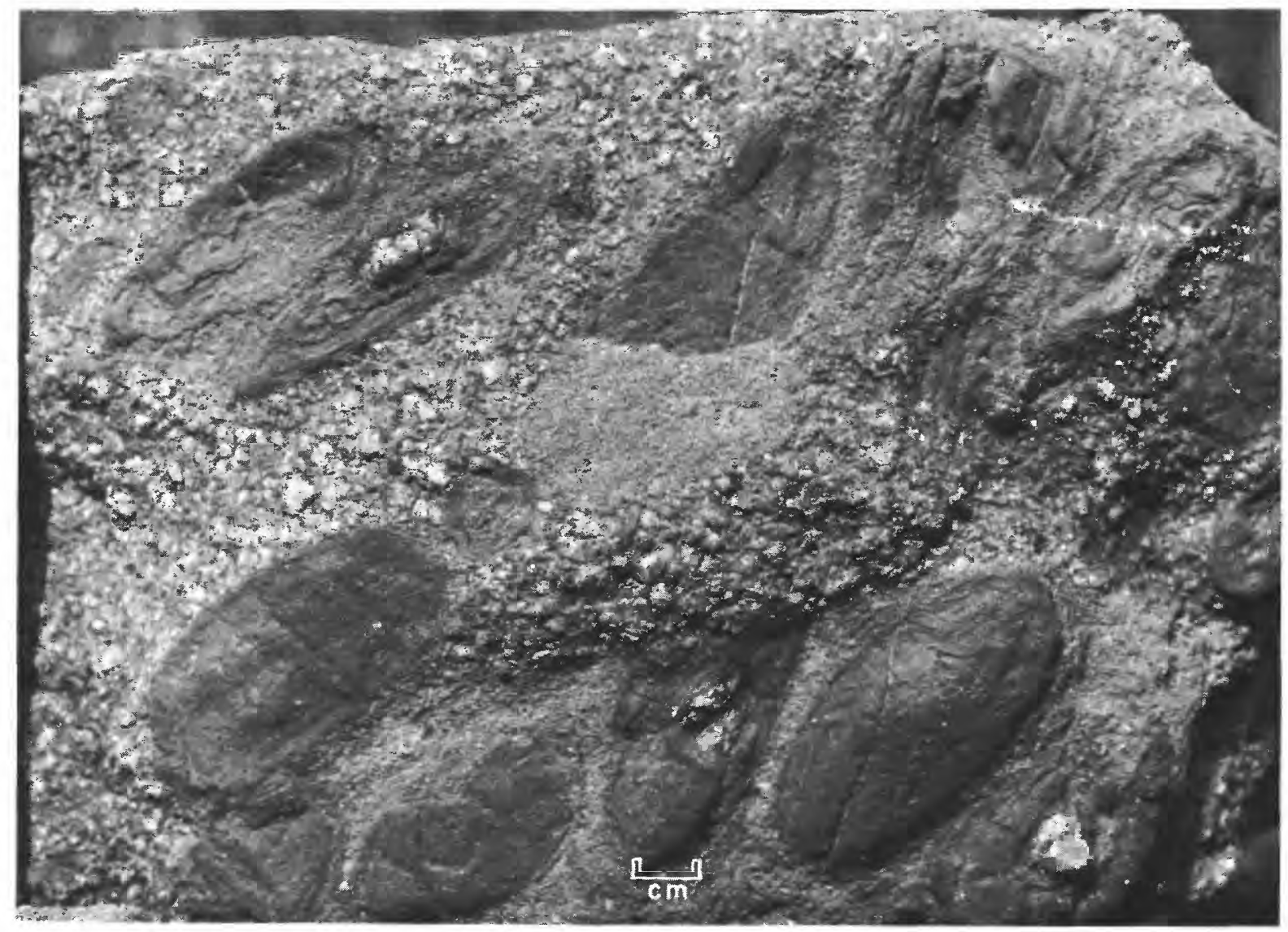

FIgURE 9.-Hematite concretions in basal bed of the Cercadinho formation. Note quartz nuclei. 
A large part of the Cercadinho formation is composed of light-gray ferruginous quartzite. The color is caused by a mixture of white to colorless quartz grains and flaky specular hematite and ranges from light to dark gray depending on the amount of hematite. The quartzite has been partly disaggregated by weathering and leaching, so that the rock in most exposures has the appearance and texture of sandstone rather than that of quartzite. The weathered material is medium to coarse grained and is poorly sorted. The quartzite is not everywhere completely disaggregated by weathering into its original grains but rather in places weathers to small fragments that consist of broken sand grains cemented by secondary quartz.

The amount and distribution of hematite in the ferruginous quartzite varies greatly. Hematite in any one place may be rather evenly disseminated throughout the rock; it may, in other places, be more or less concentrated into bands. This latter type could be mistaken for itabirite and probably has been. Careful examination usually shows that the hematite layers are crossbedded and are not strictly parallel to the true bedding. In the area of this report, the ferruginous quartzite is almost invariably coarser grained than the itabirite. It is probable that the banded black and white quartzite beds that are highest in iron contain less iron than does most itabirite. The layers containing the greatest amounts of hematite are interpreted as having been deposited with highly ferruginous mud.

The ferruginous quartzite occurs in beds ranging from 20 to 40 centimeters in thickness, each separated by silver-colored layers of phyllite ranging from 2 to 10 centimeters in thickness. (See fig. 10.) Much of the ferruginous quartzite is crossbedded, and in places this structure is useful in determining the top of beds. However, this crossbedding is the littoral type in which the

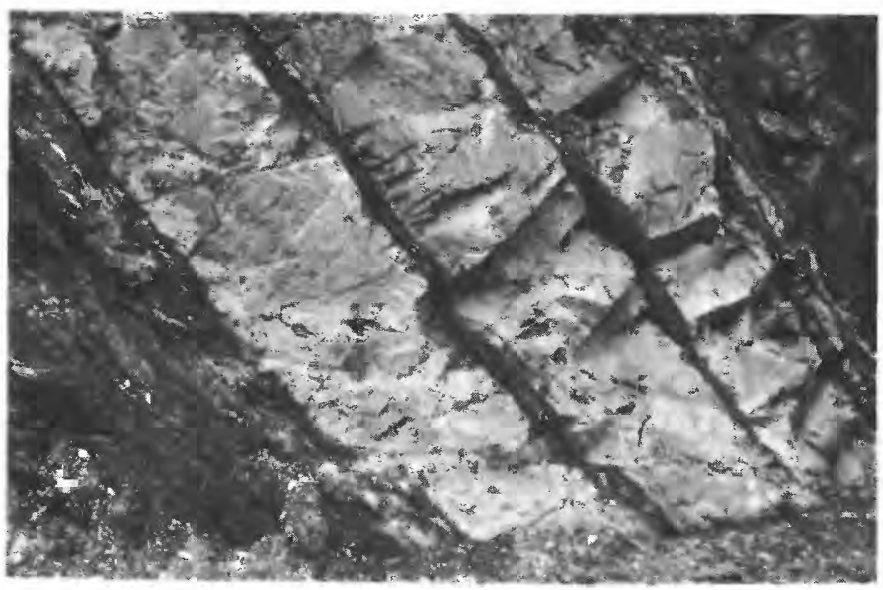

Figure 10.-Cercadinho formation exposed in roadeut at Belo Horizonte N. 4,430 , E. 6,180 . Ferruginous quartzite with thin layers of silver-colored phyllite. foreset beds form very low angles with the true bedding, so that where the rock has been distorted or sheared, the crossbedding is not a reliable criterion for determining the sequence of deposition. Such is the case in most of the ferruginous quartzite in the Belo Horizonte and Ibirité quadrangles.

Oscillation ripple marks occur in ferruginous quartzite in the Belo Horizonte quadrangle at N. 4,100, E. 5,450 . Here the quartzite strikes N. $80^{\circ} \mathrm{W}$., and dips $15^{\circ} \mathrm{S}$. Troughs of the ripples are filled with highly ferruginous phyllite, but the crests are covered with only thin films of this phyllite. The overlying bed is ferruginous quartzite. The ripple marks show that the beds are right side up at this point. Inasmuch as regional evidence conclusively shows that the rocks in this belt are overturned, the upright beds must be on a minor fold.

A distinctive quartzite peculiar to the Cercadinho formation contains about 50 percent of rice-shaped granules. It has been given the field term "rice grit." Although it is a distinctive and easily recognized bed, its thickness is generally somewhat less than 1 meter. The stratigraphic position of the "rice grit" is indeterminate beyond the knowledge that it occurs stratigraphically above the lower nonferruginous quartzite. Whether it represents one bed or many lenses at different stratigraphic positions has not been determined because in no exposure has the rock been traced more than 50 meters along the strike.

The mean size of the rice-shaped granules in one specimen is 1 by 2 by 3 millimeters; they occur in a matrix of medium-grained ${ }^{3}$ ferruginous quartzite. The same ratio of granular dimensions applies also to somewhat larger or smaller granules. Granules in any one outcrop tend to be of uniform size and shape. The size range for the entire mapped area is from about 6 millimeters for the longest dimension down to a size little larger than those of matrix grains and hence no longer distinctive.

The orientation of the axes of the "rice" granules is the characteristic that makes this thin unit important. The grains are almost perfectly alined, with the longest axes parallel to the bedding, and pointing generally in the direction of dip. The shortest axes are approximately perpendicular to the bedding. Original deposition of these grains as elongate, rice-shaped granules is doubtful. Quartz of granule size generally weathers and abrades to spherical or subspherical grains. If it were possible under special conditions for quartz to abrade into elongate granules, deposition in alinement

\footnotetext{
${ }^{3}$ The terms fine, medium, and coarse grained correspond to Wentworth's size classification of sand. Fine $=0.125-0.25$ millimeter; medium $=0.25-0.50$ millimeter $;$ coarse $=0.50-1.0$ millimeter
} 
would be unlikely. It seems probable that these granules at the time of deposition were subspherical. It follows therefore that their present shape is due to distortion during folding.

The description of phyllite of the Cercadinho formation is based principally on the appearance of weathered rock, the bulk of which is light gray, tan or reddish, and contains in many places scattered grains of hematite and magnetite. The color probably depends to a large extent on the degree of weathering, and so differing colors of a bed from place to place apparently do not reflect differences in original composition. The gray, tan, and red phyllites form the major beds between zones of dominantly ferruginous quartzite and rarely contain interbeds of such quartzite.

Silver-colored and ferruginous phyllites are both associated with the more resistant ferruginous quartzite, and so are more likely than not to be well exposed in roadcuts and in stream valleys. Silver-colored phyllite has a highly distinctive metallic luster not found in any other stratigraphic unit in the Quadrilátero Ferrífero. Ferruginous phyllite is dark purplish red. Neither of these changes color during weathering. The assemblage of ferruginous quartzite with these two types of phyllite forms an excellent criterion of the Cercadinho formation.

Thin beds of iron-rich phyllite overlying medium- to coarse-grained ferruginous quartzite occur in some places, and may grade imperceptibly into hard hematite. These layers rarely exceed 5 centimeters in thickness. Probably they were originally layers of highly ferruginous mud deposited on slightly ferruginous sand.

The quartzite, like the phyllite, is slightly to highly ferruginous and in places grades into sandy hard hematite. A polished section of hard hematite from the Cercadinho formation in the Ibirite quadrangle shows that it consists dominantly of hematite grains 0.01 and 0.02 millimeter in diameter. Petrographic evidence indicates that the hematite has replaced grains of clear quartz. The quartz grains that remain range in size from 0.01 to 1.0 millimeter. Irregular grains of magnetite about 0.01 millimeter in diameter are disseminated through the hematite.

A mass of relatively coarse grained hematite occurs a short distance east of the southwest corner of the Belo Horizonte quadrangle, at the contact between the Gandarela and the Cercadinho formations. Both formations are ferruginous at this point, and the iron apparently recrystallized where shearing took place during folding. A polished section shows this material to be an aggregate of hexagonal hematite crystals. Many of the tabular hexagonal plates that are oriented with the edge normal to the plane of the section appear bladed in the section. Diverging plates leave many angular pores. Those crystals that are virtually parallel to the plane of the section show well-defined hexagonal outlines, with an average diameter of 0.45 millimeter. The texture of this material is quite different from the texture of most hard hematite in which euhedral crystals are scarce or lacking.

In the Belo Horizonte quadrangle yellow-stained quartz sand, brown splash rock, and crusts of manganese oxide are found at N. 1,440, E. 3,000. They are considered to represent the residue of leached impure dolomite.

Many lenses of manganiferous dolomite, 10 to 20 meters thick, some represented by "black splash" and weathered rock, are found in the hills at Ibirité, N. 6,200, E. 5,700 and at N. 8,700, E. 9,800. These dolomitic lenses are not restricted to any one bed in the formation.

FECHO DO FUNIL FORMATION

The Fecho do Funil formation, consisting of argillaceous dolomite, dolomitic phyllite, and phyllite was described and named by G. C. Simmons (1958). The type locality is in the Brumadinho quadrangle adjoining the Ibirite quadrangle on the west.

There are few outcrops of the formation in the three quadrangles covered in this report, and the best exposures of the formation are in roadcuts in the southwest part of the Belo Horizonte quadrangle. The formation was mapped originally as the phyllitic zone between the Cercadinho formation and the Taboões quartzite.

Figure 8, the columnar section of the lower part of the Piracicaba group, shows the stratigraphy of the Fecho do Funil formation as it appears in weathered rock in the above-mentioned roadcuts. In these exposures the formation contains beds of pale-gray to pinkish-gray phyllite, olive-gray and purplish-gray phyllite, and brownish-orange schist with scattered octahedrons of magnetite. Porous, spongy, brown phyllite and zones of ocherous clay soil with admixed sandy or cherty material are interpreted as being leached dolomitic phyllite and leached sandy, argillaceous dolomite.

Fresh, hard, dolomite is uncommon in the Fecho do Funil formation of this area. Only three small outcrops of hard dolomite were seen. All three are exposed within 200 meters of Belo Horizonte N. 4,900, E. 7,200. The rock there is a light-gray dolomite breccia which has been highly sheared. Red sandy dolomite and white dolomite are the most common included fragments. The beds are only 3 meters thick, and none can be traced laterally for more than 10 
meters. The dolomite breccia in the three outcrops may well be part of one lens; if so, the mass is at least 300 meters long.

The mapped width of the steeply dipping Fecho do Funil formation ranges from 25 to 550 meters. The latter width is probably due to structural complications. In most places the outcrop width is about 150 meters.

$$
\text { TABOÕEs QUARTZITE }
$$

The Taboões (approximate pronunciation-Tah-bohoys) quartzite, characteristically a very fine grained rock, was named and described by the author (Pomerene, 1958). The type locality is near the head of Corrego Taboões near the center of the Ibirité quadrangle (N. 7,500, E. 7,850). The Taboones quartzite has been traced continuously for about 30 kilometers across the Brumadinho and Ibirite quadrangles and for about 5 kilometers in the western part of the Belo Horizonte quadrangle. It thins to the northeast and only thin lenses are present in the eastern part of the Belo Horizonte quadrangle. It has been mapped in the quadrangles south of the Macacos quadrangle where it has proved to be a valuable marker bed in working out complicated structure in a dominantly phyllitic terrain.

A similar quartzite is associated with graphitic phyllite in a pyrite mine near Ouro Preto in the southeastern part of the Quadrilátero Ferrifero.

At the type locality, the stratigraphic thickness of the Taboões quartzite is 121 meters. Its maximum outcrop width in these three quadrangles is about 300 meters at a point slightly west of the middle of the Ibirité quadrangle. Tables 5,6 , and 7 show measured sections of the Taboões quartzite.

The lower limit of the formation is the conformable contact between fine-grained Taboões quartzite and the phyllite or dolomitic phyllite of the underlying Fecho do Funil formation. Its upper limit is the contact be-

TABLE 5.-Section of the lower part of the Piracicaba group. Ibirité quadrangle, $N .7,500, E, 7,850$

\begin{tabular}{|c|c|c|c|c|}
\hline Series & Group & Formation & $\begin{array}{l}\text { Thickness } \\
\text { (meters) }\end{array}$ & Character \\
\hline \multirow{5}{*}{ 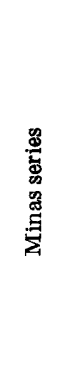 } & \multirow{4}{*}{ 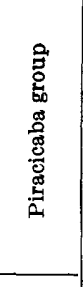 } & Barreiro formation & $\begin{array}{l}\text { Not } \\
\text { measured }\end{array}$ & Schist, purplish-gray. \\
\hline & & Taboões quartzite & 121 & $\begin{array}{l}\text { Quartzite, light-brown to } \\
\text { white, porous, fine- } \\
\text { grained. }\end{array}$ \\
\hline & & $\begin{array}{l}\text { Fecho do Funil forma- } \\
\text { tion. }\end{array}$ & 127 & $\begin{array}{l}\text { Dolomitic phyllite, pink- } \\
\text { ish-tan. }\end{array}$ \\
\hline & & $\begin{array}{l}\text { Cercadinho formation } \\
\text { Disconformity }\end{array}$ & 84 & $\begin{array}{l}\text { Quartzite, ferruginous with } \\
\text { interbedded phyllite. }\end{array}$ \\
\hline & 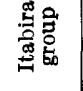 & Gandarela formation & $\begin{array}{l}\text { Not } \\
\text { measured }\end{array}$ & Limonitic itabirite. \\
\hline
\end{tabular}

tween fine-grained quartzite and phyllite or graphitic phyllite of the overlying Barreiro formation.

Taboões quartzite, where little weathered, is a very hard, fine-grained, translucent rock. Such material is exposed in only a few places. Outcrops commonly contain rock that is weathered to a friable sandstone or, as in many places, to a fine sand. Differences in friability and in color are the only visible variations in the Taboões quartzite. Both of these are attributed to degree of weathering and probably have no stratigraphic significance.

The hard quartzite ranges from light gray to paleolive gray. Under the microscope the quartzite is seen to consist of a mosaic of quartz grains that range in size from 0.04 to 0.06 millimeter in diameter. Some elongate quartz grains are about 0.04 millimeter long and 0.02 millimeter wide. The partly weathered rock appears strikingly different. It seems to consist of grains ranging from 0.5 to 1.0 millimeter in diameter, an effect apparently caused by the formation of pore spaces as much as 0.4 millimeter long between relatively large light-colored aggregates of fine-grained quartz. The walls of the pores are stained brown giving the rock a curiously speckled appearance.

Even the comparatively unweathered, hard, translucent quartzite has a few brown-stained pores. With continued weathering, more quartz is dissolved to produce more pores, until the rock has the texture of sand-

TABLE 6.-Section of Taboōes quartzite, Barreiro formation, and lower part of the Sabari formation, Piracicaba group, Minas series, Ibirité quadrangle, N. 5,700, E. 2,500

\begin{tabular}{|c|c|c|c|}
\hline $\begin{array}{l}\text { Form- } \\
\text { ation }\end{array}$ & $\begin{array}{l}\text { Total } \\
\text { thick- } \\
\text { ness }\end{array}$ & $\begin{array}{c}\text { Thickness } \\
\text { (meters) }\end{array}$ & Rock type and description \\
\hline \multirow{3}{*}{ 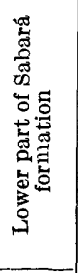 } & \multirow{3}{*}{$21.4+$} & 20.5 & $\begin{array}{l}\text { Schist or conglomeratic phyllite, variegated purple, } \\
\text { gray, white, olive green, buff. Dominantly purplish } \\
\text { gray with white clay spots (feldspars?). Possibly } \\
\text { tuffaceous. }\end{array}$ \\
\hline & & 0.3 & $\begin{array}{l}\text { Phyllite, white, maroon, black. White is high in clay, } \\
\text { maroon is iron-stained phyllite, black is probably } \\
\text { manganiferous. }\end{array}$ \\
\hline & & 0.6 & $\begin{array}{l}\text { Schist or phyllite conglomerate. Contains bits of } \\
\text { graphitic, gray, greenish, and yellowish phyllite, } \\
\text { average size } 0.5 \mathrm{~mm} \text { by } 7 \mathrm{~mm} \text {. }\end{array}$ \\
\hline \multirow{5}{*}{ 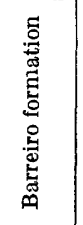 } & \multirow{5}{*}{32.6} & 18.8 & Graphitic phyllite, sheared and locally highly contorted. \\
\hline & & 1.5 & $\begin{array}{l}\text { Quartzite, black, extremely fine-grained appearance } \\
\text { like chert. Graphitic phyllite partings. }\end{array}$ \\
\hline & & 0.7 & Graphitic phyllite. \\
\hline & & 10.6 & Quartzite weathered to yellowish sand, mixed with soil. \\
\hline & & 1.0 & Schist, pinkish-brown. \\
\hline \multirow{5}{*}{ 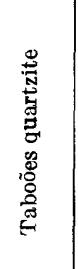 } & \multirow{5}{*}{96.0} & 13.0 & $\begin{array}{l}\text { Quartzite weathered to yellowish sand, slumped and } \\
\text { mixed with soil. }\end{array}$ \\
\hline & & 17.0 & Quartzite, fine-grained, medium brown, friable. \\
\hline & & 36.0 & $\begin{array}{l}\text { Quartzite, pale brown with tiny dark brown pores, } \\
\text { partially disaggregated, friable. Slightly banded due } \\
\text { to differential weathering along joints. }\end{array}$ \\
\hline & & 10.5 & Quartzite, greenish buff; disaggregated to sand. \\
\hline & & 19.5 & Quartzite; disaggregated to fine-grained white sand. \\
\hline
\end{tabular}


OF PARTS OF MINAS GERAIS, BRAZIL

stone. Ultimately the rock disintegrates to a finegrained sand.

During the above process the rock changes from gray to speckled brown to brown and ultimately to white.

In a sand pit near the center of the Ibirité quadrangle (N. 7,950, E. 7,370), the Taboões quartzite is sufficiently coherent to stand as vertical walls, yet it is so disaggregated that it can be dug with a pick and spade. The degree of leaching is not uniform since some of the sand is pure white and some is stained brown. A chemical analysis of this sand furnished through the courtesy of Magnesita, S. A., is as follows:

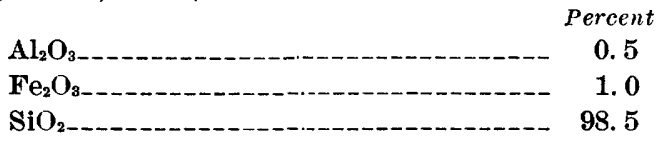

BARREIRO FORMATION

The name Barreiro (approximate pronunciationBah-ráy-roo) formation was given to the phyllite and graphitic phyllite that overlie the Taboões quartzite (Pomerene, 1958). The formation occurs continuously for more than 24 kilometers and in sporadic outcrops for another 15 kilometers. The type locality is a short distance south of the northeast corner of the Ibirite quadrangle where the road from Barreiro to the Serra da Rola Moça is parallel to and about 300 meters west of the Corrego do Barreiro. The formation is 107 meters thick at the type locality. The lower limit is the top of the Taboões quartzite; the upper limit commonly is marked by a lavender-colored conglomeratic phyllite that is included in the overlying Sabara formation.

The Barreiro formation is characterized by beds of black, graphitic phyllite. It also contains nongraphitic phyllite and purplish schist, as well as a few thin beds of black and white siliceous rock which are presumed to be crystallized chert. A detailed section of the Barreiro formation, the Taboones quartzite, and the Fecho do Funil formation is given below (table 7). This was measured at the type locality of the Barreiro.

The Barreiro formation is an easily mappable unit for about 15 kilometers in the Ibirite quadrangle. This formation, like the Taboones quartzite, is exposed widely but sporadically across the Belo Horizonte quadrangle. The formation has not been recognized in the Nova Lima quadrangle to the east. Its sporadic occurrence in the Belo Horizonte quadrangle and its absence in the Nova Lima quadrangle suggest that the formation becomes lenticular to the east. It extends westward across the Brumadinho quadrangle and may extend even farther west into quadrangles that have not been mapped geologically as of 1958. Graphitic phyllite, apparently in the same stratigraphic position as the Barreiro, has been seen in many other quadrangles of
TABLE 7.-Section of part of the Piracicaba group at the type 7ocaitly of the Barreiro formation, Ibirité N. 12,800, E. 12,670

\begin{tabular}{|c|c|c|c|}
\hline Formation & \multicolumn{2}{|c|}{$\begin{array}{l}\text { Thickness } \\
\text { (meters) }\end{array}$} & Rock type and description \\
\hline Sabará & \multicolumn{2}{|c|}{ Not measured } & Soil with fragments of conglomeratic phyllite. \\
\hline Barreiro & 107 & $\begin{array}{r}15 \\
5 \\
9 \\
16 \\
4 \\
7 \\
3 \\
30 \\
7 \\
4 \\
1 \\
6\end{array}$ & $\begin{array}{l}\text { Graphitic phyllite with maroon phyllite layers. } \\
\text { Graphitic phyllite with quartz-pyrite knots. } \\
\text { Graphitic phyllite. } \\
\text { Graphitic phyllite with occasional red schist layers. } \\
\text { Schist, light-gray. } \\
\text { Graphitic phyllite; with occasional red schist layers. } \\
\text { Reddish schist. } \\
\text { Graphitic phyllite; with scattered knots of pyrite. } \\
\text { Graphitic phyllite. } \\
\text { Schist, tan to pink. } \\
\text { Quartzite, fine-grained, black and white. } \\
\text { Phyllite, gray-orange. }\end{array}$ \\
\hline $\begin{array}{l}\text { Taboões } \\
\text { quartzite }\end{array}$ & & 16 & Quartzite, fine-grained. \\
\hline $\begin{array}{l}\text { Fecho } \\
\text { do } \\
\text { Funil }\end{array}$ & 74 & $\begin{array}{r}13 \\
5 \\
11 \\
12 \\
5 \\
2 \\
1 \\
5 \\
4 \\
2 \\
1 \\
\\
2 \\
1 \\
2\end{array}$ & $\begin{array}{l}\text { Soil. } \\
\text { Schist, coarse-grained, gray-orange. } \\
\text { Soil, with fragments of pink and gray schist. } \\
\text { Phyllite, interbedded olive-brown and light-gray. } \\
\text { Schist, pale-olive. } \\
\text { Schist, gray-brown. } \\
\text { Phyllite, gray. } \\
\text { Phyllite and schist, grayish-brown. } \\
\text { Phyllite and schist, yellow-orange. } \\
\text { "Black splash" rock (leached manganiferous } \\
\text { dolomite). } \\
\text { Sand, fine-grained, buft color, manganese crusts } \\
\text { (dolomite?). } \\
\text { Phyllite, dark-gray. } \\
\text { Olive to orange phyllite. } \\
\text { Sand, fine-grained, brown; with manganese (leached } \\
\text { dolomite?). }\end{array}$ \\
\hline Cercadinho & Not $m$ & & Soil, sandy; with phyllite fragments. \\
\hline
\end{tabular}

the Quadrilátero Ferrífero but normally crops out too poorly to be mappable.

The lower beds of the Barreiro formation consist of nongraphitic phyllite resting conformably on Taboões quartzite. In the section measured at Barreiro, this phyllite is about 11 meters thick and is grayish-orange, tan, and pink with black and white mottling on bedding planes. In a section measured at Belo Horizonte N. 5,140 , E. 6,730 (table 8), the upper part of the basal phyllite is light gray and black, but the mottling on the

TABLE S.-Scction of Barrciro formation, Belo Horizonte quadrangle, $N .5,140, E .6,730$

\begin{tabular}{|c|c|c|}
\hline \multicolumn{2}{|c|}{$\begin{array}{l}\text { Thickness } \\
\text { (meters) }\end{array}$} & \multirow{2}{*}{$\frac{\text { Rock type and description }}{\text { Phyllite, conglomeratic, of Sabará formation }}$} \\
\hline & $\begin{array}{c}\text { Not } \\
\text { measured }\end{array}$ & \\
\hline 28.60 & $\begin{array}{r}2.00 \\
.10 \\
.40 \\
1.85 \\
.95 \\
.60 \\
3.65 \\
.55 \\
.25 \\
.75 \\
11.90 \\
.10 \\
1.50 \\
.10 \\
2.70 \\
1.20 \\
\text { Not } \\
\text { measured }\end{array}$ & $\begin{array}{l}\text { Phyllite, graphitic, with quartz-pyrite knots. } \\
\text { Phyllite, gray-orange and pink. } \\
\text { Phyllite, light-gray. } \\
\text { Phyllite, light-gray, conglomeratic. } \\
\text { Graphitic phyllite, with pale-red layers. } \\
\text { Phyllite, pale-orange. } \\
\text { Schist, light greenish-yellow. } \\
\text { Schist, dark yellow-orange. } \\
\text { Phyllite, dark yellow-orange. } \\
\text { Phyllite, interbedded pale-orange and graphitic. } \\
\text { Graphitic phyllite. } \\
\text { Sand, light-gray, with pyrite crystals. } \\
\text { Graphitic phyllite. } \\
\text { Sand, light-gray, with pyrite crystals. } \\
\text { Graphitic phyllite. } \\
\text { Phyllite, interbedded light-gray and dark-gray. } \\
\text { Not exposed. }\end{array}$ \\
\hline
\end{tabular}


bedding planes is consistently black and white. Compare section (table 8) with the section of the Barreiro formation described above (table 7).

A bed of graphitic phyllite overlies the basal phyllite in all exposures in the area of this report. The graphitic phyllite commonly, but not everywhere, is divided roughly into a lower bed and an upper bed separated by a zone of essentially nongraphitic phyllite and schist. The division is not absolute as both the upper and lower beds may contain many minor beds of nongraphitic material, and the middle bed in many places has seams of graphitic phyllite. In the type section the lower graphitic beds are about 37 meters thick, the middle essentially nongraphitic beds about 14 meters, and the upper graphitic beds total about 55 meters. In the Belo Horizonte section the graphitic beds are much thinner; the lower graphitic bed is $\mathbf{1 7}$ meters thick, the middle beds are 8 meters, and the upper graphitic bed is only 2 meters thick. Figure 11 shows the two prominent graphitic beds in another exposure in a newly graded area near Belo Horizonte.

The upper contact of the Barreiro formation is not as sharp as the lower. The top is nearly everywhere marked by the base of a peculiar lavender-colored conglomeratic or gritty phyllite, but in places this conglomeratic phyllite also occurs interbedded in the upper part of the graphitic phyllite. The top is arbitrarily defined, therefore, as the contact between the uppermost significant graphitic bed and the conglomeratic phyllite.

One analysis made in the laboratory of the Departamento Nacional da Produção Mineral, (Boletin de Análise No. 12852) by Srta. Aida Espinola, showed the carbon content of the graphitic phyllite to be 4.4 percent. If there were a use for weathered phyllite with this amount of graphite, a large tonnage of soft material could easily be mined.

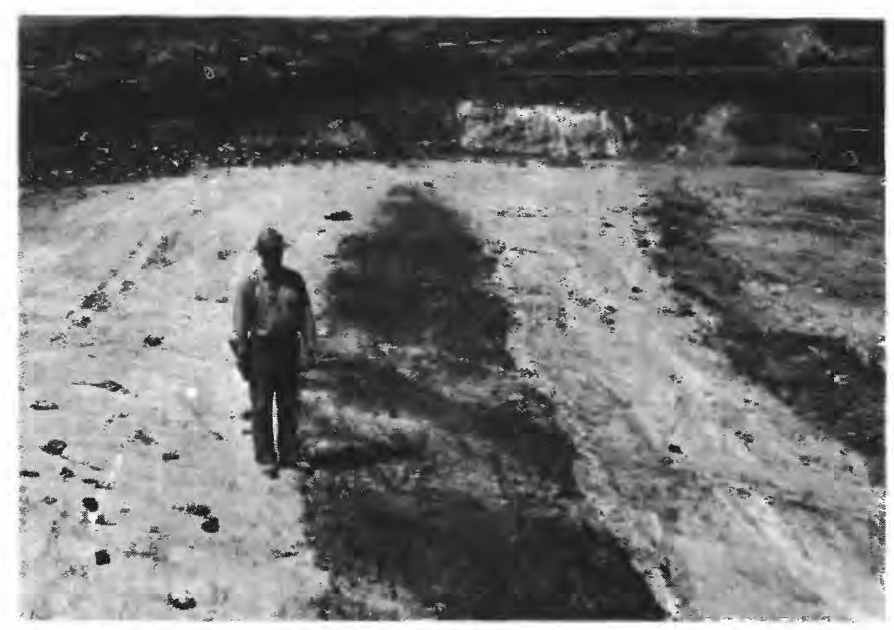

Figure 11.-Graphitic beds of the Barreiro formation near Belo Forizonte.

$686-2890-64-3$
Some graphitic phyllite was mined in the past from several small pits and open cuts at Ibirité N. 8,700, E. 9,050 . It is said to have been used in the manufacture of dark-gray paint, but detailed and accurate information is not available.

Graphitic phyllite which may correlate with the Barreiro formation is mined for its pyrite in the southeastern part of the Quadrilátero Ferrifero. In the area mapped in this report pyrite is not abundant; occasional cubic molds in the graphitic phyllite suggest that the formation may contain a small percentage of pyrite below the zone of weathering.

\section{SABARÁ FORMATION}

The Sabará formation consists of phyllite, quartzite, graywacke, and metavolcanic rocks (Gair, 1958). Although recognized as a mappable unit during this study, its type section was established by Gair and the author in the Nova Lima quadrangle along the road between Sabará and General Carneiro, about 7 kilometers east of the Belo Horizonte quadrangle. In that area the formation is better exposed than at any point in the Belo Horizonte or Ibirite quadrangles. The Sabara formation is by far the thickest of all subdivisions in the Piracicaba group.

The Sabara formation occurs in the western part of the Ibirite quadrangle and extends toward the northeast across the Belo Horizonte and Nova Lima quadrangles. Westward it extends across the Brumadinho quadrangle, but its full westward extent is not yet known. It also has been mapped in the Lagôa Grande quadrangle, south of the area covered in this report.

In the area covered by this report the maximum mapped width of 3,400 meters occurs in the northeastern part of the Ibirité quadrangle. The stratigraphic thickness cannot be determined in this area because the formation is poorly exposed and the upper part is in contact with intrusive granite. It is probable that the thickness of the formation exceeds 3,000 meters.

In the Ibirité and Belo Horizonte quadrangles nearly all exposures of the Sabará formation are too thoroughly weathered to obtain samples suitable for sectioning and microscopic study. The few relatively fresh specimens collected are subgraywacke, graywacke, and chloritic quartzite. According to Gair, some of the beds exposed in the type locality are probably metavolcanic rocks.

The base of the Sabará formation commonly is marked by a bed of lavender-colored conglomeratic phyllite overlying graphitic phyllite of the Barreiro formation. Locally a transition zone several meters thick occurs in which graphitic phyllite and conglomeratic phyllite are interbedded. 
The upper part of the formation has been altered to staurolite schist by intrusive granite. The staurolite schist is sufficiently distinctive to be shown separately on the map, even though it is only a metamorphic zone and not a stratigraphic unit. It has a maximum mapped width of 1,600 meters in the northeast part of the Ibirité quadrangle.

\section{METASEDIMENTARY ROCKS OF INDETERMINATE AGE}

Fine-grained quartzite, some of which is graphitic, occurs in the younger granite gneiss of the Ibirité quadrangle. Whether this quartzite is a remnant of the upper part of the Sabará formation or whether this metamorphosed rock is from a formation older than the Sabará is not known.

Another extremely fine-grained quartzite occurs in the granite gneiss some 100 to 800 meters north of the contact between the granite gneiss and the staurolite schist. This quartzite is known locally as "pedra de amolar" or, in English, whetstone. The rock is similar in appearance to Arkansas novaculite and is a very good sharpening stone.

As shown in the measured section below (table 9), thin beds of this quartzite are generally intercalated with granite gneiss in a zone about 50 meters thick. The quartzite is pink to white and very fine grained. The unit can be traced for more than 5 kilometers along the strike in the north-central part of the Ibirite quadrangle. Pedra do amolar has not been recognized elsewhere in the three quadrangles considered in this report. The correlation of this rock is not known; it may represent incompletely granitized remnants of the upper part of the Sabará formation, or it may represent part of the Taboões quartzite repeated by synclinal folding. Some support is given the latter speculation by the occurrence of one outcrop of graphitic quartzite in contact with and on the south side of a "novaculite" exposure at Ibirité quadrangle N. 10,000, E. 3,400. This may be equivalent in part to the Barreiro formation.

TABLE 9.-Section through railroad cut at Ibirité N. 11,600$E .4,600$ measured from northwest to southeast.

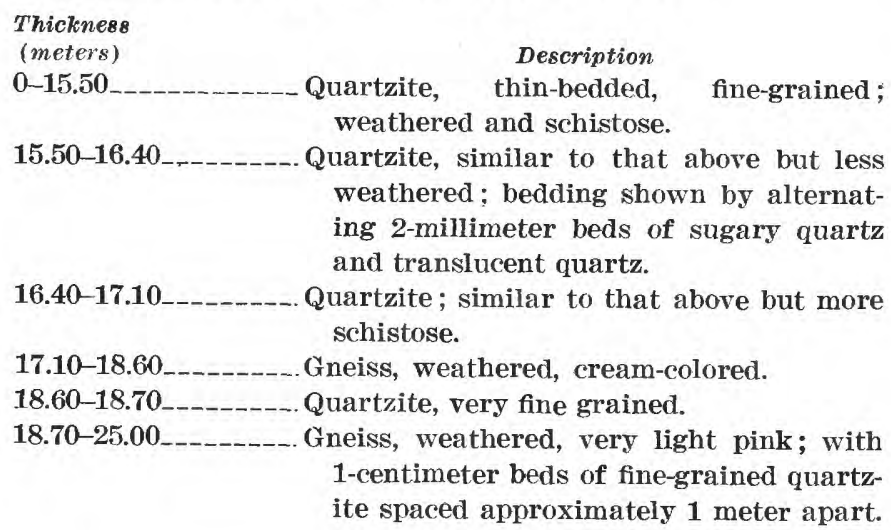

TABLE 9.- Section through railroad cut at Ibirité N. 11,600E. 4,600 measured from northwest to southeast.-Continued

Thickness

(meters)

$25.00-25.10$

Description

$25.10-29.00$ Quartzite, very fine grained.

Gneiss, pink to white weathered; with a few 1-centimeter thick beds of finegrained quartzite.

$29.00-30.00 \ldots . .0$. Dike or basic band in gneiss.

30.00-31.00_._._. Gneiss, pale cream-colored, weathered.

31.00-34.40_._._. Dike or basic band in gneiss.

34.40-42.50_._. Gneiss, pale cream-colored, weathered.

42.50-44.60_._.... Gneiss, weathered, cream-colored; with beds of fine-grained quartzite from 1 to 10 centimeters thick.

44.60-61.00_._._. Granite, coarse, gray-white, weathered, gneissic; banding obscure. A few 1-centimeter beds of fine-grained quartzite.

61.00-76.00___._._. Gneiss, cream-colored, weathered.

76.00

TERTIARY AND QUATERNARY SEDIMENTS

Tertiary and Quaternary sedimentary deposits in the Quadrilátero Ferrífero consist of alluvium, canga, ironore rubble and boulders, limonitic sandstone, clay, highlevel stream gravels and small amounts of lignite. They occur sporadically in all parts of the Quadrilatero Ferrifero, but the soft materials occur most commonly where resistant beds of itabirite and quartzite have protected them from erosion. Within the Belo Horizonte, Ibirité, and Macacos quadrangles, their extent is much greater than appears on the maps, and the beds are shown only where the writer considers them to be physiographically, geologically, or economically of more immediate importance than the underlying Precambrian rocks. Lignite does not occur in the area of these three quadrangles. Because relatively recent rocks of several different ages form overlapping and interfingering deposits of similar lithology, most of them cannot be described in stratigraphic sequence.

The Tertiary age of some of these sediments was first established by Gorceix, 1884, when he found fossil plants in lignite at Gandarela. The fossils were identified as of Miocene or possibly Pliocene age. The fossil-bearing beds dip $30^{\circ}$ to $40^{\circ}$ in some places. Although this has been interpreted as evidence for Tertiary regional tilting (Brajnikov, 1957, p. 321-335), the present writer believes that the dip is partly due to the initial dip of beds deposited in and along the sides of sinkholes in dolomite, and partly due to subsequent collapse of sinkholes.

The rocks of Tertiary and Quaternary ages contain material of economic value including hematite boulders, rubble, canga, bauxite, and clay; all are described below in the section on economic geology.

Large areas of these sediments occur in the Macacos quadrangle over the middle of the Moeda syncline. 
Throughout most of this area the sediments cannot be accurately dated and they are shown on the map as Tertiary to Quaternary in age. Near the southern border of the quadrangle, on the east shore of Lake Miguelão, plant fossils were found that established a Tertiary age for some of this material.

The bulk of the Tertiary and Quaternary sediments are heterogeneous valley fills consisting of ferruginous clays and grains of quartz, hematite, and limonite. An iron content of 30 to 40 percent is common. Most of these sediments are poorly stratified and overlie either canga or weathered Precambrian rocks. Thickness is as much as 100 meters. One or more thin layers of canga may be present above the base of these sediments.

\section{SANDSTONE AND STRATIFIED CLAY}

The unit containing plant fossils mentioned above is exposed in two places near Macacos quadrangle, $\mathrm{N}$. 500, E. 4,500 . In the southern outcrop a 1-centimeter bed of fossiliferous limonitic sandstone dips southward about $7^{\circ}$. It is overlain by stratified pink and brown clay about 2.5 meters thick, which is overlain by 1 meter of red and ocherous-banded clay. This in turn is overlain by 1.5 meters of red clay soil containing many peasized concretions of limonite. Canga, 50 centimeters thick, overlies the red soil and forms the surface at this locality.

The northern exposure of the fossiliferous unit is a broken outcrop of limonitic sandstone about 10 meters below the high water level of Lake Miguelão. The locality is usually accessible from September to November as the lake almost disappears each year during the dry season. The fossiliferous bed is overlain by 20 to 30 meters of poorly exposed stratified clay and limonitic sandstone capped by a sheet of canga. It should be stressed that the fossils have no relation to the lake, which is artificial and only a few decades old.

The best fossils are impressions of various kinds of leaves. Specimens were sent to the Paleontology and Stratigraphy Branch of the U.S. Geological Survey, where they were identified by Roland W. Brown as a fern and dicotyledonous leaves of Tertiary age. Figures $12 A$ and $12 B$ are photographs of two specimens.
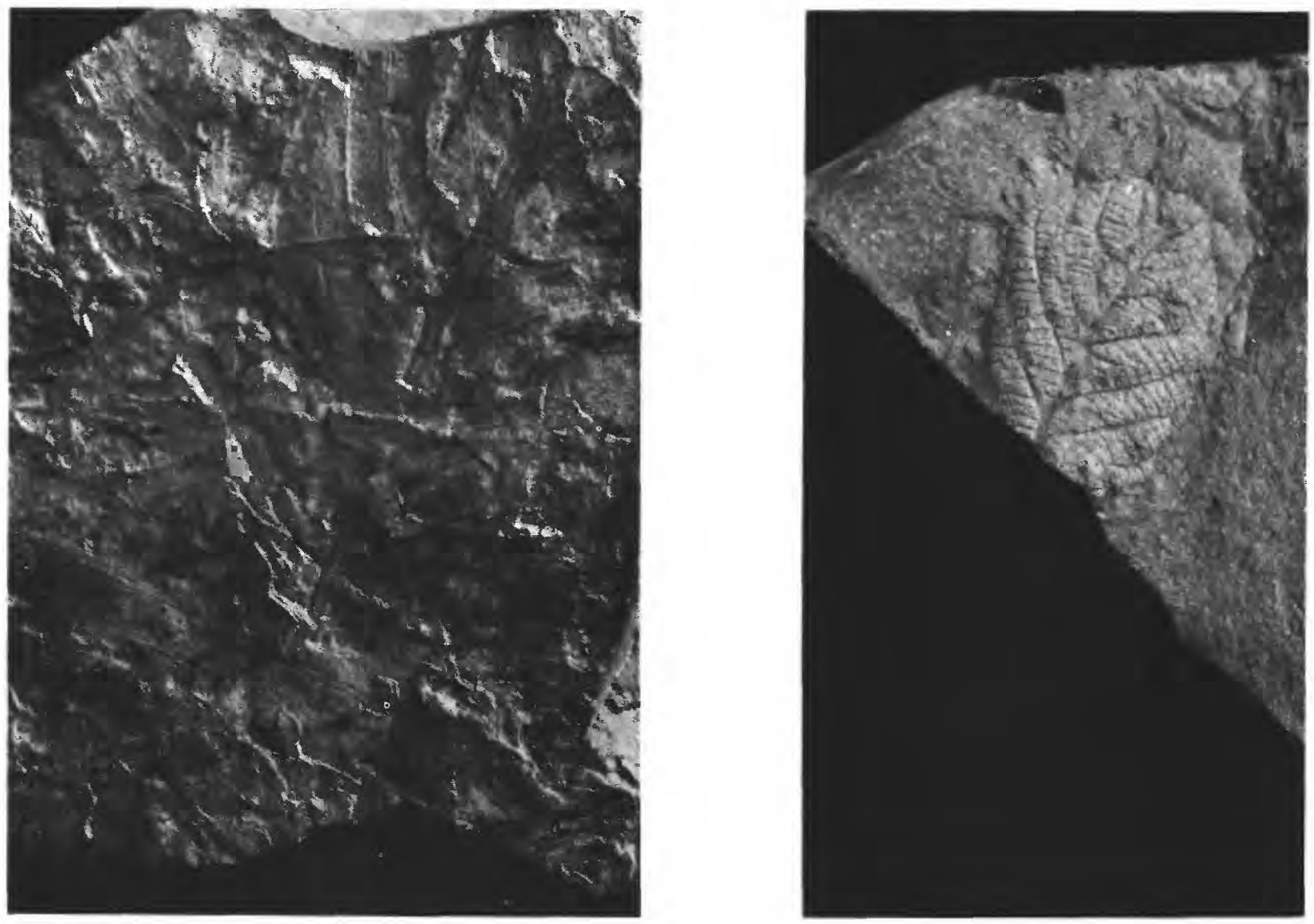

Figure 12.-Fossils in limonitic sandstone from broken outcrop in the bed of Lagôa Miguelão in the southern part of the Macacos quadrangle. $A$ (left) fern, $B$ (right) dicotyledonous leaves. 
CANGA

Canga is an indurated, ferruginous rock consisting of fragments of iron-formation, hard hematite and, less commonly, other materials cemented into sheetlike masses by hydrated iron oxide, precipitated at or near the surface. Its iron content ranges from about 40 to 68 percent.

Canga occurs in the Quadrilátero Ferrífero on most of the prominent ridges formed by the Caue itabirite. In many places it covers the slopes of ridges as well as the crests and may extend beyond the ridges for several kilometers out over essentially nonferruginous formations including granite, as near Fazenda da Jangada in the Ibirité quadrangle.

Canga may overlie Quaternary and Tertiary sediments and in places may be interbedded with them.

The thickness of the canga is commonly between 2 and 10 meters, but its thickness varies depending to a large extent on the "pre-canga" topography.

The writer believes that canga forms near the surface, beneath a few centimeters to several meters of ferruginous, soil. Its formation beneath relatively thin soil cover relates it directly to an erosion surface. This, in the case of the almost concordant summits of the iron-bearing ridges of the Quadrilátero Ferrifero, implies that much of the canga is related to a former peneplain.

Probably large areas of the Quadrilatero Ferrifero were covered with a canga sheet, which formed beneath ferruginous soil outwash from the ridges of the ironformations toward the end of the period of peneplanation. After uplift of the region, rejuvenated streams rapidly eroded and destroyed most of this canga, so that only a relatively small percentage of the sheet remains.

In the Belo Horizonte, Tbirité, and Macacos quadrangles erosion of canga commonly is due to the removal of underlying soft rocks, so that the canga capping eventually falls by gravity. (See fig. 13.)

Canga can be classified into three general types:

1. Canga rica-a breccin-conglomerate of hard hematite cemented by a minimum of limonite.

2. Ordinary canga-hematite chips and itabirite fragments cemented by a considerable amount of limonite.

3. Chemical canga-mostly limonite, cementing clay and ferruginous soil.

Canga rica is a term applied to a breccia-conglomerate with more than 66 percent $\mathrm{Fe}$ and composed of boulders, cobbles, and fragments of hard hematite cemented by a minimum amount of limonite. Canga rica occurs down slope from and in the vicinity of hematite deposits in the Cauê itabirite.

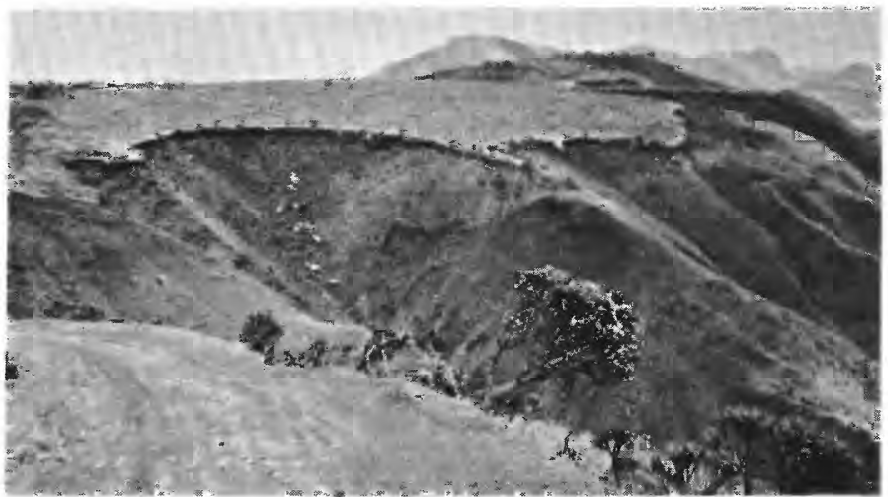

Figure 13.-Canga capping being destroyed by removal of softer material beneath. Blocks of canga, broken by gravity, appear in the valley in the left. middle foreground. Serra de Rola Moca, Ibirite quadrangle.

Ordinary canga occurs commonly, but sporadically, throughout the extent of the Cauê itabirite in the Quadrilátero Ferrífero. It, too, is a breccia-conglomerate composed of chips of hematite and fragments of itabirite from which much of the silica has been removed by leaching. The conglomerate is cemented by limonite. All proportions of hematite and itabirite occur, and so the grade naturally varies greatly. Much of this type of canga is valuable ore, and some is used at present in charcoal blast furnaces.

Most ordinary canga contains 50 percent of more iron. Even where ordinary canga occurs over itabirite with no hard hematite ore nearby, its grade is generally higher than that of the itabirite because of surface leaching of the silica.

Canga consisting of ferruginous soil cemented by limonite, or a limonitic "hardpan," is referred to in the report as chemical canga. Commonly it occurs some distance from the iron-formation where the ferruginous material has been reduced to sand, silt, or clay size by transportation.

Chemical canga recently denuded of soil cover has a botryoidal surface structure (see fig. 14) and is thought to have been still growing until the time of removal of its cover of 10-20 centimeters of ferruginous soil. After denudation of the soil cover, the surface of the chemical canga breaks down from a grape-cluster to a broken-bubble form. (See fig. 15.) This canga was stripped of its soil cover a few years ago, which deprived it of a source of ferruginous material for further growth, and exposed it to erosion and solution by rainwater.

\section{MUDSTONE AND TERRACE GRAVELS}

An unusual type of Quaternary and Tertiary material has been given the field term "mudstone." It is a semi-indurated rock that can be dug with a pick but not with a shovel or spade. A striking characteristic 


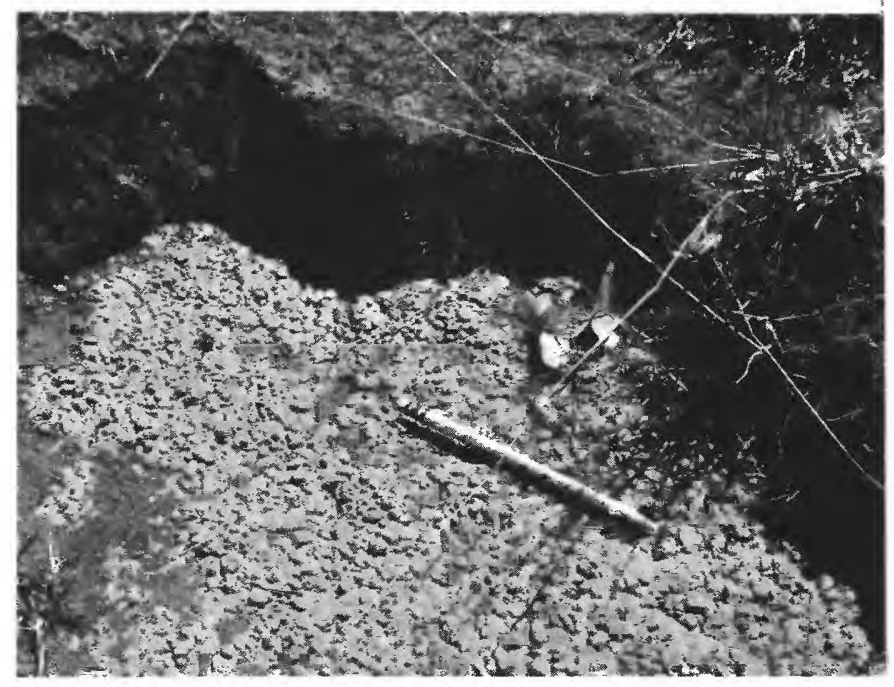

Frgure 14.- Surface of chemical canga now forming. Canga flat above Lagôa Miguelão, Macacos quadrangle.

of the mudstone in this area is that little vegetation grows on it. Not a blade of grass or vestige of moss or lichen can be found over tens of square meters. This mudstone may rarely support hardy bushes whose roots are in deep cracks filled with dust and powdered mudstone reworked by rainwater. Exposed surfaces of mudstone, besides being absolutely barren of vegetation, commonly are grossly mammillary.

This material was described by Guild (1957) as weathered dolomite because in the Congonhas area it only occurred along the projection of the strike of dolomitic rocks. Further evidence supporting Guild's belief is that all mudstone exposures in the three quadrangles described in this report are along the projected strike of the dominantly dolomitic Gandarela formation. However, exposures of mudstone in other quadrangles of the Quadrilátero Ferrifero contain evidence in the form of disoriented, angular fragments of itabirite, and broken pieces of vein quartz that suggest the possibility of a detrital origin. One such exposure, visited by the writer, is in a deep gully near the old Belo Horizonte-Nova Lima highway where this road crosses the Gandarela terrain in the Nova Lima quadrangle.

The present writer believes that mudstone has formerl virtually in place and is a type of laterite derived from siliceous, ferruginous dolomite. Soil creep and slump may have transported it a short distance horizontally or downward. The fragments of itabirite, vein quartz, and quartzite occur near the base of the mudstone, and, because they are all relatively insoluble oxides, may represent "unlaterized" bits of the original formation.

Such materials are common in the Gandarela formation, and crystallized ferruginous chert from the Gan-

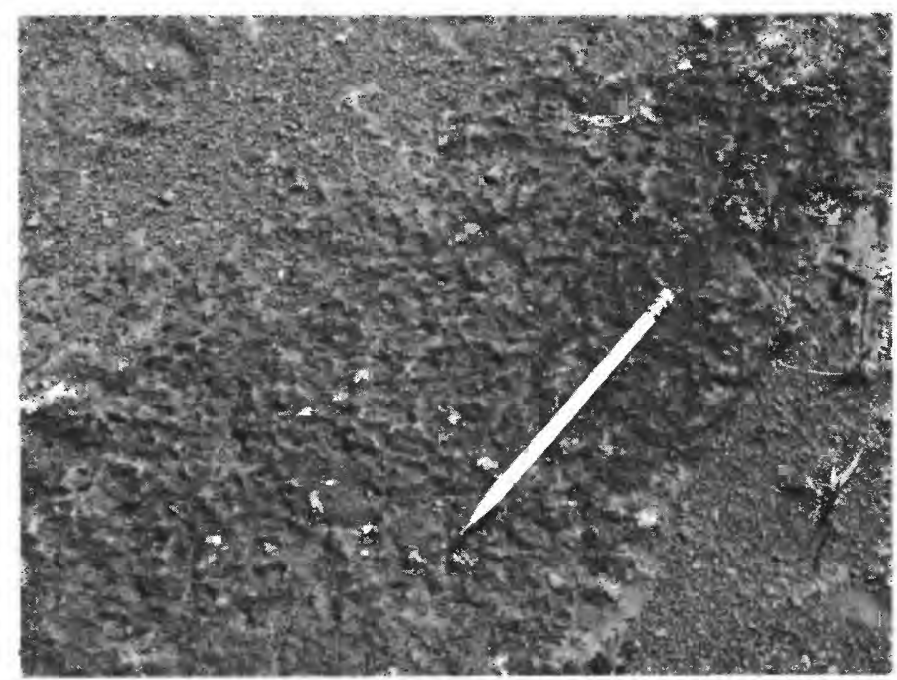

Figure 15.- Surface of slightly weathered or "dead" canga; vertical view at a point 35 meters from view in figure 14 .

darela formation can, when deeply weathered, appear to be fine-grained, ferruginous quartzite.

The basal zone of any laterite commonly contains relatively unaltered fragments of the underlying rock as has been observed in laterite in the Surigao province of Mindanao, Philippines, where fragments of serpentinite are sparsely scattered through a thin basal zone of the laterite. 'This laterite contains much material similar to mudstone. Fragments of materials more resistant to weathering than serpentinite, such as quartz and iron oxide, can be expected to be disseminated through a much thicker zone.

Terrace gravels occur at several levels and probably represent both Tertiary and Quaternary sediments. In the vicinity of Macacos, in the Macacos quadrangle, there are several gravel terraces. Deposits on the highest level consist almost entirely of well-rounded pebbles, cobbles, and boulders of vein quartz. The upper limit of these gravels is about 100 meters above the present major stream. Another gravel terrace occurs about 30-40 meters lower. This gravel is composed dominantly of very well rounded cobbles of hard hematite with a minor amount of round, vein quartz. The difference in composition between the two deposits is interesting but cannot be satisfactorily explained. Many of the gravels have been worked for placer gold (see p. D79).

\section{IGNEOUS AND GNEISSIC ROCKS}

Large parts of the Belo Horizonte and Ibirité quadrangles are underlain by massive or gneissic rocks of granitic composition. Although some of these rocks are intrusive and others probably are granitized sedimentary rocks, both are described in this section because of their lithologic similarity. 
Ultramafic rocks, now altered to serpentinite and talc schist, and gabbro now altered to metagabbro and talc schist intrude the metasedimentary rocks of the Nova Lima group. Diabase and metadiabase dikes, possibly of several ages, intrude both metasedimentary rocks and granitic rocks. Pegmatitic veins occur in the contact zone between intrusive granite and metasedimentary rocks, and quartz veins are common in all the rocks of the area.

\section{GRANITIC ROCKS}

Recent work by Herz (1958) has shown that granitic rocks of at least four ages occur in the Quadrilatero Ferrifero. The ages have been determined by $A r^{40} / \mathrm{K}^{40}$ ratios in biotite in the laboratories of the Department of Geology and Geophysics of the Massachusetts Institute of Technology under the direction of Professor P. M. Hurley. Herz and Dutra (1958) have used suites of trace elements to correlate other granites with those for which the four ages have been established.

The four granites so far dated during this cooperative study àre as follows:

1. Granodiorite at Engenheiro Corrêa 2,524-2,440 million years old.

2. Granite at Itabirito $1,300-1,260$ million years old.

3. Granodiorite at Cachoeira do Campo 760-720 million years old.

4. Granite at Itabira and other younger granites 560475 million years old.

Granites in the Belo Horizonte, Macacos, and Ibirité quadrangles are known to correspond in age only to two of the dated granites, in the ranges of 1,330-1,260 million years (Itabirito) and $560-475$ million years (Itabira).

Granite gneiss from the Prado Lopes quarry $(1,260$ million years) at Belo Horizonte (N. 11,000, E. 5,100) is of the same general age as granite from Itabirito (1,330 million years). Trace element suites of the two are similar and differ from those of any of the other three granites. Most of the granite and gneiss north of the Serra do Curral in both the Belo Horizonte and Ibirité quadrangles is probably of this general age. However, a granite considered to be the youngest in this region (475-560 million years old) occurs between upper rocks of the Minas series and the granite gneiss of the type found in the Prado Lopes quarry.

Herz (1958) reports that the granite of the type in the Prado Lopes quarry is, like the granite at Itabirito, well foliated and banded with felsic-rich layers alternating with biotite-rich layers. Augen of microcline up to 10 millimeters are common. The general grain size of microcline is 3 to 6 millimeters; plagioclase and orthoclase are somewhat smaller; quartz is about 0.5 millimeter and biotite, about 0.3 millimeter in largest dimen- sion. Large mafic schlieren and xenoliths are common in this granite, and the rock is cut by small veins of pegmatite and aplite. The pegmatite is composed mainly of feldspar, quartz, micas, and black tourmaline.

Some of these features are shown in figures $16,17,18$, and 19 .

A modal analysis of the granite at Prado Lopes by Herz shows that the rock has 40 percent microcline, 4 percent orthoclase, 25 percent plagioclase, 20 percent quartz, and 10 percent biotite. White mica, colorless amphibole, and some xenotime, magnetite, chlorite, and apatite, comprise about 1 percent of the rock.

Two exposures of granite south of Casa Branca in the Ibirité quadrangle were sampled and found to be equivalent to the youngest granites ( $560-475$ million years old). One of them at Ibirité N. 2,700, E. 3,280, was dated by the $\mathrm{Ar}^{40} / \mathbf{K}^{40}$ ratio, the other at Ibirité N. 1,600, E. 8,000 , was correlated on the basis of similarity of suites of trace elements (Herz and Dutra, 1958). Granite from the town of Barreiro on the north side of the Serra do Curral is also correlated with these younger granites because it is in contact with the Sabará formation of the upper Minas series and has formed by contact metamorphism a belt of staurolite schist within the Sabará. However, granite still farther north of the Serra do Curral probably is of the same age $(1,260$ million years) as that at the Prado Lopes quarry. The contact between the two has not been found.

The younger granites and granite gneisses in this area are of extremely varied mineral content. According to Herz $(1958$, p. 24), they range in mineral composition as follows: oligoclase 10-35 percent, potash feldspar 15-35 percent, quartz 25-40 percent, biotite 1.5-15 percent, white micas in trace to 16 percent, epidote in trace to 5 percent, and chlorite 0 to 4.5 percent; accessory minerals include xenotime (up to 1 percent), zircon, allanite, apatite, carbonate (1 percent in one sample), magnetite, and leucoxene.

A sharp contact between granite and the quartzite and conglomerate of the Moeda formation is well exposed near Samambaia at N. 2,900, E. 2,900 in the Ibirité quadrangle. Lenses of conglomerate about 1 meter long and 0.5 meter thick occur stratigraphically at the base of the quartzite, occupying places that were depressions during deposition of these strata. The conglomerate consists of rounded pebbles of quartz, 2 to 5 centimeters in diameter, angular fragments of fine-grained greenish phyllite as much as 5 centimeters long, and a quartzite matrix. The field appearance is that to be expected of gravel and sand deposited on basement granite. However, microscopic examination shows that the quartzite contains crystals of albite. Granite exposed about 300 meters south of this locality 


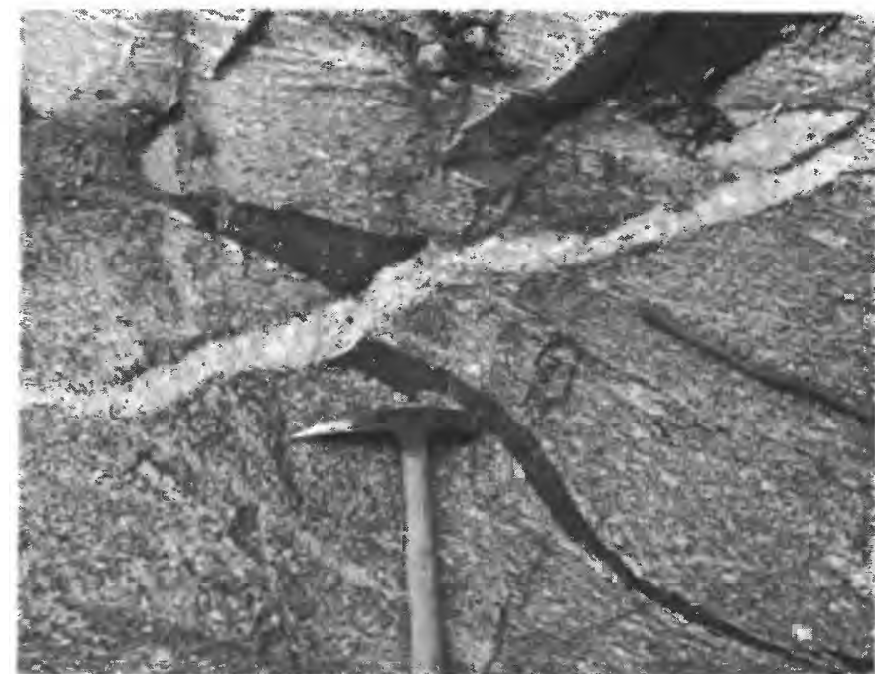

Figure 16.-Narrow pegmatite vein which has formed along fault Mafic schlieren in granite gneiss shows offset; Prado Lopes quarry.

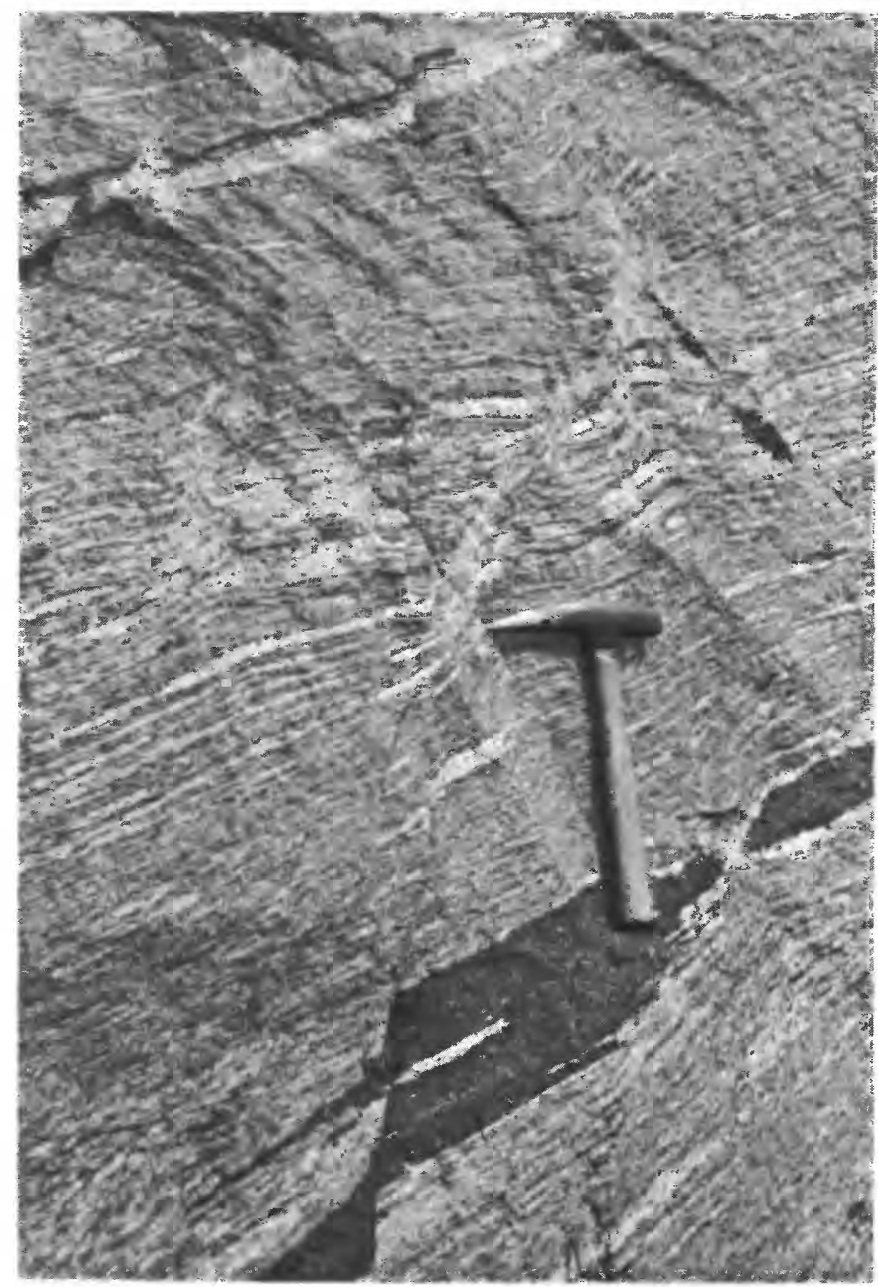

Figure 17.-Fault in granite gneiss at Prado Lopes quarry. Hard and brittle rock of mafic schlieren failed by fracture; granite gneiss above the schlieren failed by fiowage.

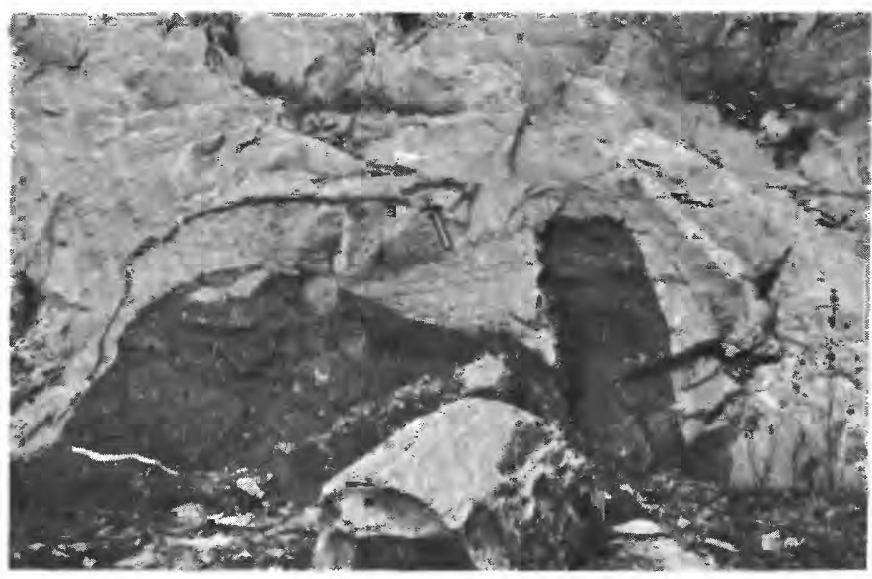

Figure 18.-Mafic xenolith in grantte gneiss in Prado Lopes quarry.

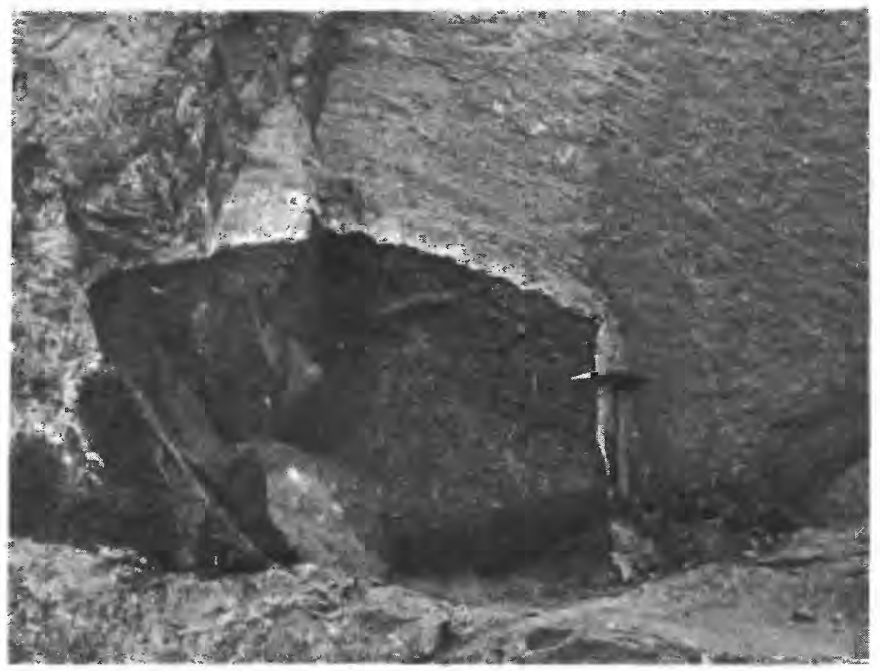

Figure 19.-Xenolith in granite in roadcut, about 100 meters south of Prado Lopes quarry. Granite shows flowage lines and reaction rim around xenolith.

is between 475 and 560 million years old. Granite of this type is known to intrude rocks of the Minas series in other places. The consensus as of 1958 is that the granite is post-Minas in age but at the level of the Moeda formation in the crust it had cooled to the point that it had almost no metamorphic effect other than albitization on the conglomerate, the contained phyllite fragments, or the quartzite.

Still another mass of granite is quarried at Morro da Pedra in the Belo Horizonte quadrangle at N. 6,000, E. 3,600. It is not gneissic as are most of the other granitic rocks and contains distinctive pale-green feldspar. From a distance a faint lineation can be seen, but close to the outcrop it is impossible to see or to measure its attitude. It is definitely intrusive into the upper part of the Minas series (Sabará formation) because it has metamorphosed the country rock, through 
contact, to the biotite isograd, although subsequently there was general retrogression of biotite to chlorite (Herz and Dutra, 1958, p. 94). This metamorphism indicates that the mass is relatively young, but its relationship to the 475-560 million-year old type of granite is not established. Studies by Herz (1958) show that the granite at Morro da Pedra consists of about 30 percent quartz, 20 percent microcline, 11 percent orthoclase, 24 percent oligoclase, 7.5 percent biotite, 4.5 percent white mica, 0.3 percent chlorite, 2 percent epidote, and minor amounts of opaque minerals, zircon, and apatite.

Small dikes of this type of granite, also containing greenish feldspar and possessing faint foliation, occur in granite of the Prado Lopes type a few hundred meters west of the Belo Horizonte quadrangle.

A peculiar dark-gray, coarsely crystalline rock, exposed only in a few outcrops, occurs around the granite at Morro da Pedra in the Belo Horizonte quadrangle. It seems to represent an argillaceous sediment that has been granitized and crushed. Where weathered, this rock is difficult to distinguish from weathered granite gneiss and the contacts of the mass are indefinite. It is conceivable that a band of this rock, too weathered to be recognizable, may lie between the granite and the staurolite schist in many other places.

Small exposures of deeply weathered crystalline rock occur in roadcuts near the village of Macacos. (See fig. 20.) The material is probably derived from granitic rock because it has weathered to light-pink saprolite which is similar to weathered gneissic granite in other places. No sample of this rock suitable for sectioning was found. Although shown on the map as small dikes and irregular masses, and as dikes on the

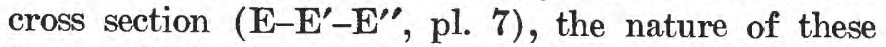
igneous bodies is not known. They occur many kilometers distant from any known large granitic mass.

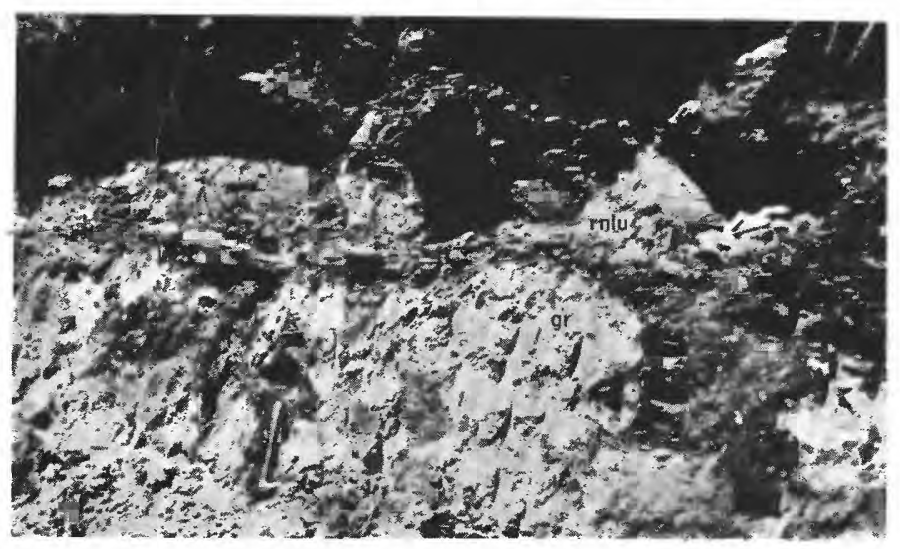

Frgure 20.-Granitic rock intrusive into schist of the Nova Lima group.

\section{MAFIC INTRUSIVE MASSES}

A medium- to coarse-grained rock classified as metagabbro occurs in two widely separated places in these three quadrangles. Near the western edge of the Ibirité quadrangle in granite terrain (N. 1,000, E. 1,800 ) a train of large boulders of metagabbro can be traced for about 100 meters, but this rock was not seen in place.

In the southeast corner of the Macacos quadrangle a relatively large and arcuate mass of medium- to coarse-grained metagabbro is associated with talc schist and serpentinite in terrain of Rio das Velhas series rocks. The metagabbro consists of actinolite, hornblende, plagioclase (mostly albite), clinozoisite, and zoisite. Commonly the metagabbro is separated from the serpentinite by a zone of talc schist. Evidence found underground at the southwest end of the main level in the Cruzeiro asbestos mine (pl. 13) indicates that the metagabbro has been partly altered, or replaced by talc near the contact with the serpentinite. In most places this zone is sheared, resulting in talc schist, although the rock locally retains a gabbroic texture and appearance even when it is composed mostly of talc.

As shown in fig. 40 (map of the serpentinite area) both metagabbro and talc schist are in contact with the Moeda formation of the Minas series. Whether the contact is sedimentary or intrusive has not been established with certainty. The metamorphosed mafic and ultramafic rocks are intrusive into rocks of the Rio das Velhas series whereas, along the contact between the mafic and ultramafic rocks and Minas series, no intrusive relationship was found. It therefore appears probable that in this area the basal rocks of the Minas series were deposited on the eroded surface of the mafic and ultramafic rocks.

Serpentinite occurs at three localities in the three quadrangles of this report. Two minor occurrences were found in the Belo Horizonte quadrangle; one consists of two dikelike bodies in the vicinity of Belo Horizonte N. 1,600, E. 6,200; the other is a very small, deeply weathered mass at Belo Horizonte N. 1,700, E. 8,500 .

The major serpentinite body, 4 kilometers long and about 2 kilometers wide, occurs in the southeastern corner of the Macacos quadrangle and in the southwestern part of the adjoining Rio Acima quadrangle. The northern and eastern parts of the serpentinite body are in contact with rocks of the Nova Lima group of the Rio das Velhas series; the southwestern part of the serpentinite is in contact with the talc schist and metagabbro described above. The serpentinite, according to Gair (written communication, 1956), con- 
sists almost entirely of antigorite, in part pseudomorphous after olivine. This area is of economic interest because of asbestos veins developed along shears in the serpentinite, as is discussed under "Economic geology -asbestos."

\section{DIABASIC DIKES}

Of the several types of dike rock in the Belo Horizonte, Ibirité, and Macacos quadrangles, those of diabasic composition are the most common. They are found in both the metasedimentary rocks and in the granites.

Mineralogically, the diabase dikes are similar, consisting of lathlike plagioclase twinned according to the Carlsbad law, in a ground-mass of pigeonite with accessory biotite and ilmenite, and secondary chlorite and sericite. In partly altered diabase the pigeonite is rimmed with uralite and partly replaced with chlorite and magnetite. The plagioclase is partly replaced by quartz and chlorite. In the highly altered diabase, pigeonite is partly replaced by chlorite and the plagioclase is partly replaced by epidote. Ilmenite is partly altered to leucoxene. Apatite and tremolite are present in some of the highly altered diabases. The diabasic texture is progressively destroyed with increased alteration.

Alteration is so common that in only 1 thin section out of 10 could the rock be considered relatively unaltered, and in 6 of the sections alteration was sufficiently advanced as to almost obliterate the diabasic texture.

One interpretation of the differing degrees of alteration of the dikes is that the process is related to local variations in degree of metamorphism. It is conceivable, however, that the different stages of alteration indicate different ages of intrusion, because the only almost unaltered diabase occurs in the contact metamorphic staurolite schist zone in the Ibirité quadrangle and must be postmetamorphic. These features suggest that there were two or three periods of intrusion of diabase.

Several of the dikes contain phenocrysts of feldspar as large as 1 by 3 centimeters. Although they are strikingly different from the ordinary diabase in outcrop or hand specimen, thin sections show that the two types of dikes are the same except that one contains the large phenocrysts. 'The porphyritic diabase dikes are distinguished from the other diabase dikes on the quadrangle maps. A few dikes in the area show no trace of diabasic texture even in thin section. They are probably of different composition, but because of metamorphic alteration and weathering, it is not possible to classify them.

\section{VEINS}

All of the sedimentary rocks as well as most of the igneous rocks in the Quadrilátero Ferrifero contain quartz veins. With the possible exception of quartzite of the Moeda formation, the Pre-Minas rocks contain many more quartz veins than the younger. Prospect pits in quartz veins are common throughout the Quadrilátero Ferrifero. They were made in search of piezoelectric quartz, but only a few yielded good material in the Belo Horizonte, Ibirité, and Macacos quadrangles, as shown by the small size and shallowness of most pits.

Quartz crystals of considerable mineralogical interest were found in rocks of the Rio das Velhas series close to the contact with the Minas series at Belo Horizonte N. 1,800, E. 6,400 . A single quartz crystal may contain inclusions both of hairlike rutile and pseudooctahedra of octahedrite (or anatase). (See fig. 21.) It is not known why $\mathrm{TiO}_{2}$ should crystallize into two different minerals in a similar or identical environment. Another quartz crystal from the same locality contains

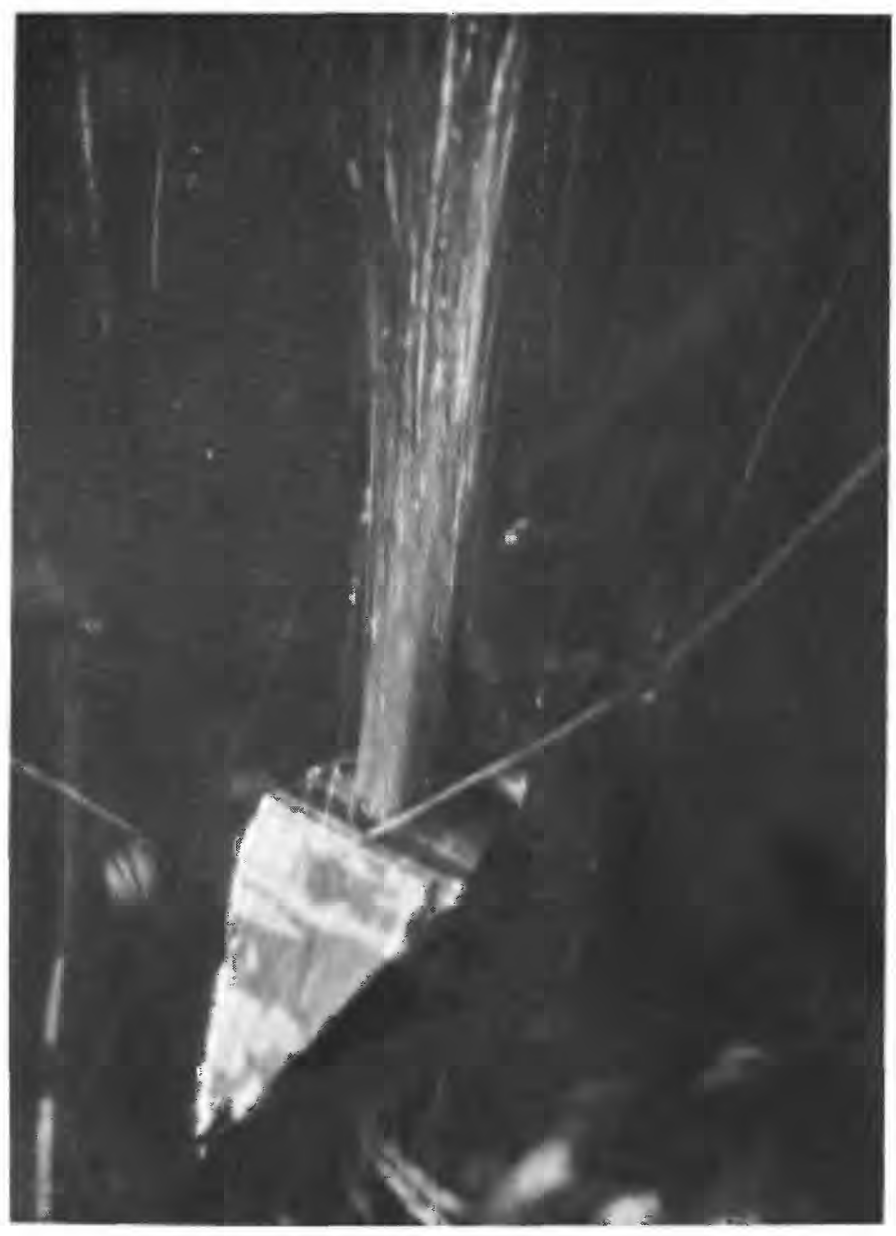

FIgure 21--Rutile and octahedrite inclusions in quartz crystal The octahedrite crystal is about 3.5 millimeters long. 


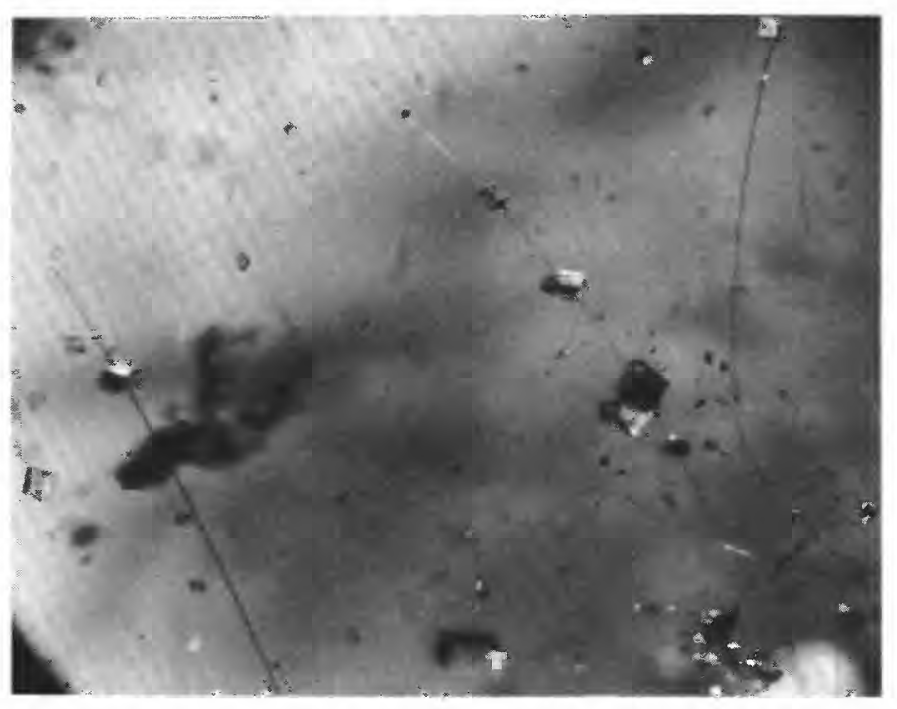

FIGURE 22.-Quartz crystal containing perfect carbonate rhombohedra that are penetrated by a single "hair" of rutile. The largest rhombohedron is about 0.4 millimeter long.

rutile "hairs" upon which perfect carbonate rhombohedra are strung like beads. (See fig. 22.)

Inclusions of chlorite and of quartz sand are common in quartz crystals, in both the Rio das Velhas series and in the Minas series. Samples studied by F. A. Hildebrand of the U.S. Geological Survey indicate in addition that some quartz crystals contain hematite. Hildebrand also determined the presence of dolomite, and so the carbonate crystals shown in figure 22 may be this mineral. One inclusion of "chlorite" was $\mathbf{x}$ rayed and determined to be isostructural with strigovite, a dark green, hexagonallike mineral with the composition of $\mathrm{H}_{4} \mathrm{Fe}_{2}(\mathrm{Al}, \mathrm{Fe})_{2} \mathrm{Si}_{2} \mathrm{O}_{11}$.

Andalusite-muscovite veins occur in the contact metamorphic zone mapped as staurolite schist of the Sabará formation. No actual vein has been observed, but in restricted areas, crystal aggregates of andalusite occur in the soil. The crystals may be as much as 4 centimeters thick and 7 centimeters long. The andalusite does not occur in sufficient volume to be of economic interest at present.

In the same metamorphic zone, a vein of deeply weathered feldspar and blue corundum was found. The corundum is minor in quantity and, although it is weathered and fractured, it will still scratch topaz. This vein occurs at Belo Horizonte N. 3,800, E. 1,600 at the side of a private farm road.

\section{METAMORPHISM}

Throughout the area described in this report, Precambrian sandstones have been changed to quartzite; chemical sediments such as iron-formation and dolomite have been crystallized to form itabirite and dolomitic marble; and shale and volcanic rock has been metamorphosed into phyllite or schist.

It is not possible to determine in detail the metamorphic history of the Rio das Velhas series; the rocks are too weathered and too poorly exposed. Much of the series consists of phyllite and schist derived from argillaceous sediments. The iron-formations of the Nova Lima group are thought to have been deposited as chemical sediments and then made granular through metamorphism. Quartzite in the Nova Lima group resulted from recrystallization of sandstone. According to Gair (1962) rocks of the Rio das Velhas series are rarely metamorphosed above the chlorite isograd.

Much the same can be said of the younger Minas series. Sediments that were originally argillaceous are now phyllite or schist. Chemical sediments have been recrystallized and metamorphosed to itabirite and impure dolomitic marble.

That metamorphism was generally mild is shown by the rarity of metamorphic minerals other than talc along bedding planes in the impure dolomite of the Gandarela formation. According to Barth (1952, p. 288-290) talc is the first mineral to develop during metamorphism of impure dolomite.

Granite has formed a contact metamorphic zone in the Sabara formation along the north side of the Serra do Curral. The rock of this zone which has an outcrop width between 200 and 1,600 meters is dominantly staurolite schist, but a few thin lenses of garnet-mica schist occur near the granite. Albite has been introduced into the quartzite by the granite mass south of the Serra in the Ibirite quadrangle but there is no other apparent contact effect. Alteration of gabbro to talc and peridotite to serpentinite may have been due partly to metamorphism or it may have been a deuteritic effect. Neither the gabbro nor the diabase produced contact aureoles in adjacent country rocks.

\section{STRUCTURE}

Structurally, the Quadrilátero Ferrífero is a highly complex fold system consisting of long, narrow, curving synclines and large, irregular anticlinal or domal structures. Rocks of the Minas series are preserved only in these major synclines, such as the Moeda syncline, and in some places along the edges of the domal structures such as the Serra do Curral. Rocks in the central parts of the domal structures are dominantly older metasediments, granites, and gneisses.

The central part of the Serra do Curral and the northern part of Moeda syncline are the dominant structural features in the area covered by this report.

The central uplift is bordered by a number of prominent synclines, one of which, the Moeda syncline, ex- 
tends into the area of this report from the southeast. The sides of these synclines are marked by mountain ridges caused by the greater resistance to erosion of rocks of the Itabira group. The two bordering ridges of the Moeda syncline are the Serra da Moeda and the Serra do Itabirito. Another ridge of this type is the one whose segments bear different names, including Serra do Mutuca and Serra do Curral, which trends diagonally toward the northeast across the area of this report. The rock formations of this mountain range have been tilted beyond the vertical. The complementary range on the opposite side of the syncline is missing probably because rocks in that area have been intruded by granite and granitized.

\section{SERRA DO CURRAL}

The structure of the Serra do Curral in its gross aspect is relatively simple. The strata are in general overturned and dip about $45^{\circ}$ to the southeast in the eastern part of the Belo Horizonte quadrangle. In the western part of the quadrangle they dip somewhat more steeply or about $60^{\circ}$ to the southeast. In the middle of the Ibirite quadrangle the lower strata forming the Serra are nearly vertical but the upper rocks of the Minas series are overturned and dip about $45^{\circ}$ to the south. (See pl. 7, secs. $A-A^{\prime}, B-B^{\prime}, C-C^{\prime}$, and $H-H^{\prime}$.)

All units of the Minas series between the Moeda and the Sabara formations occur in, or on the flanks of, the Serra do Curral. The thickness of the Minas series in the Serra ranges from about 3,000 meters in the northeastern part of Belo Horizonte quadrangle to about 5,500 meters in the western part and in the Ibirité quadrangle.

The overturned beds in the Serra do Curral are cut by normal faults, thrust faults, and tear faults, locally producing complex structures. (See sketches, fig. 23.) Only the Cauê itabirite, the Gandarela formation, and the Cercadinho formation are indicated in the sketches of figure 23. Sketch $A$ suggests the original, prefaulting extent of the beds which at present are included within the boundaries of the Belo Horizonte quadrangle as represented by the square. In sketch $B$, the beds east of the quadrangle have been displaced southwestward by compression folding. Sketch $C$ shows that a northeast-southwest couple has moved the beds farther to the southwest; at the same time it caused more drag folds in the Cercadinho formation. Continued compression shown in sketch $D$ produced combination tear and thrust faults to develop from two of the drag folds so that a block of the Cercadinho formation was isolated and overridden from both the northeast and the southwest. The sketches indicate the inferred magnitude of shortening necessary to produce the present pattern.
Structure almost identical to that shown above in sketch $D$ occurs in a microfold in a fragment of itabirite from the Serra do Curral at Fazenda Conde, Belo Horizonte, N. 1,100, E. 4,600. (See fig. 24.)

In both the Belo Horizonte and Ibirite quadrangles most of the faults in the Serra do Curral and its extensions are the result of compression, as indicated by shortening of the beds. Other faults strike at nearly right angles to the Serra.

'The fault that crosses the Moeda and Itabira groups and part of the Cercadinho formation near the western border of the Ibirité quadrangle has been interpreted as a thrust fault. West of the fault, the outcrop width of the Itabira group is considerably greater than east of the fault. Although a rotational fault that lowered the dip of the beds west of the fault could cause this apparent thickening, no significant difference in dip of beds was observed from one side of the fault to the other. There is, however, a marked difference in rock type from one side to the other within a distance of about 2 meters. East of the fault the rock is siliceous itabirite; west of the fault the rock is amphibolitic, ocherous itabirite. This is an area where the contact between Cauê and Gandarela is indistinct because of itabirite and colomitic itabirite in both formations. It is not known which formation contains the amphibolitic itabirite at this place. It seems probable that somewhat thicker amphibolitic beds west of the fault have been thrust eastward over thinner siliceous itabirite. This interpretation fits the pattern of general compression and shortening of the beds.

\section{MOEDA SYNCLINE}

The south-striking Moeda syncline on the west side of the central dome of the Quadrilatero Ferrifero is a major structural unit in the mapped area. The syncline is about 40 kilometers long and extends between the Serra do Curral on the north and the major eastwardtrending structures on the south side of the dome (see fig. 2). Arbitrarily defining the base of the syncline as coincident with the base of the Minas series, the structure is as much as $\mathbf{1 6}$ kilometers wide. The syncline throughout much of its extent is overturned to the west. Both the northern and southern ends are complicated by thrust faults.

Only the northern end of the Moeda syncline occurs within the area of this report. The structure is about 12 kilometers wide at the south edge of the Macacos quadrangle, narrowing northward to about 5 kilometers before widening in the area where it merges with the Serro do Curral. Rocks of the western limb are right side up and dip an average of $60^{\circ} \mathrm{E}$. The eastern limb is overturned, and the strata dip about $75^{\circ} \mathrm{E}$. 


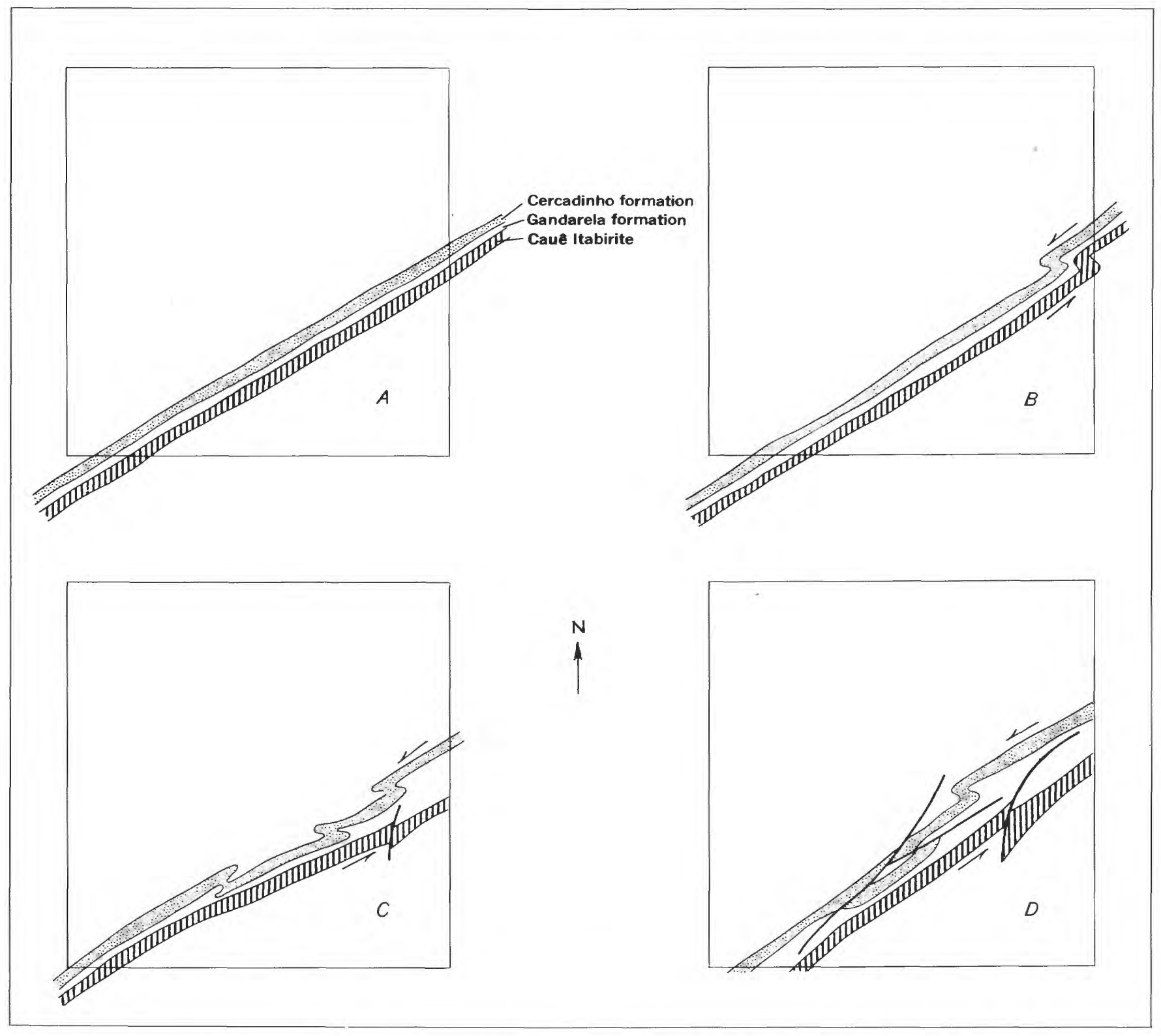

Frgure 23.- Simplified plan sketches to show the development of a hypothetical set of major faults similar to those in the Belo Horizonte quadrangle. A, Sketch suggesting the original disposition of the beds, which after folding and faulting, are included within the boundaries of the Belo Horizonte quadrangle represented by the square. $B$, Fold develops as a result of compressive force. $C$, Northeast-southwest couple has moved the beds to the southwest and has caused steeply plunging drag folds in the Cercadinho formation. $D$, Continued compression has caused combination tear and thrust faults to develop from two of the drag folds so that the Cercadinho formation has in part been isolated and overridden from both the northeast and the southwest.

Along the southern edge of the Macacos quadrangle all formations of the Caraça and the Itabira groups as well as the Ceracadinho and the Fecho do Funil formations of the Piracicaba group are present. Extensive areas of Quaternary and Tertiary sediments cover parts of these Precambrian formations. In the west-central part of the Macacos quadrangle, the Moeda syncline is narrow and less deep than along the south border of the quadrangle so that only the Caraça and the Itabira groups are present.
The depth to which the Minas series extends in the syncline is not known. Evidence in quadrangles south of the Macacos quadrangle (Rynearson and Wallace, oral communications, 1956) shows that there are minor anticlinal structures in the middle of the syncline, as reflected in structure sections $\mathrm{E}-\mathrm{E}^{\prime}, \mathbf{F}-\mathrm{F}^{\prime}$, and $\mathrm{G}-\mathrm{G}^{\prime}$ (pl. 7). The position of the keel cannot be estimated by simple projection of the dips of the limbs to a line of intersection. The cross-sectional shape of the syncline deduced from mapping is believed to be well illus- 


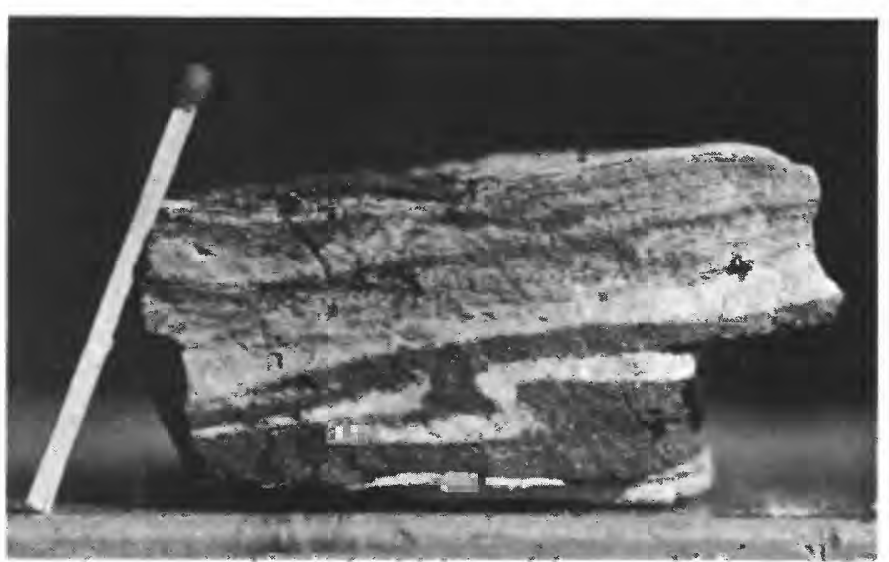

FIGURE 24.-Compression fold in itabirite. Compare this structure with that illustrated in sketch $D$, fig. 23. Match is 4.5 centimeters long.

trated in miniature by a minor double-keeled fold in ocherous itabirite in Mannesmann mine 2, in the Serra da Mutuca. (See fig. 25.) This type of a fold will explain well the differences in apparent thickness of formations on either limb of the syncline. The base of the Minas series in the Moeda syncline is judged to range in depth from 2,000 to 3,000 meters below the present surface.

At the north, the Moeda syncline merges with the structure of Serra do Curral. The eastern limb of the syncline swings to the northeast and the western limb swings sharply to the southwest, both passing into the overturned edge of the dome, physiographically expressed by the Serra do Curral.

Further complications by folding and faulting occur a few kilometers south of the junction of the Moeda syncline and the Serra do Curral. The syncline is gently crossfolded along a northeast-southwest axis. The fold has displaced part of the syncline 3 to 4 kilometers to the north and 3 to 4 kilometers to the east. Still another complication is a major thrust fault that has displaced the southern block northward for more than 6 kilometers over the northern part of the syncline.

The trace of the major thrust fault is located within about 10 meters along the east side of the Rochedo das Gaivotas in the southeastern part of the Ibirite quadrangle, (N. 3,000, E. 11,100), but the fault surface has not been seen. In the west central part of the Macacos quadrangle the location of the trace of the fault trending southeast is inferred (and may be greatly in error). From the erosion area known as Feixos, north to the hematite deposit known as Mutuca no. 2, the fault is probably shown within about 50 meters of its correct location.

In Feixos the approximate location of the fault ( $N$. 6,700 , E. 4,100 ) is indicated by repetition of strata. (See sec. $E-E^{\prime}$, pl. 7.) The western band of quartzite

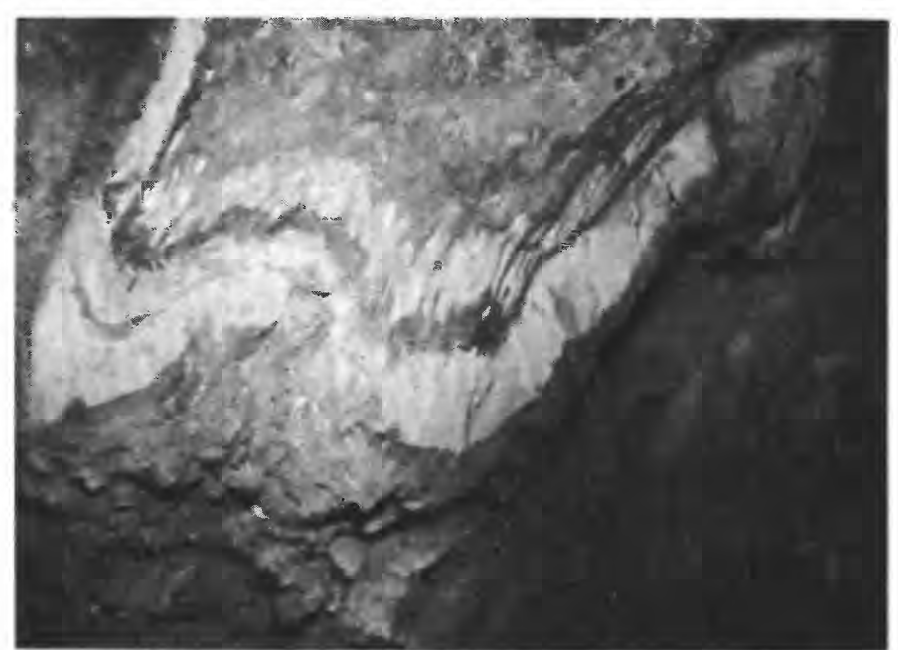

FIGURE 25.-Small compound synclinal fold in ocherous, limonitic itabirite. Mannesmann adit 2, at 61 meters, looking south. This miniature fold is believed to be comparable in cross section with the Moeda syncline.

of the Moeda formation in Feixos is cut off on the east by a breccia zone. East of the breccia zone about 70 meters of phyllite is limited on the east by a poorly exposed basic dike. East of this dike lies Cauê itabirite and the Caraça group. The phyllite is interpreted as a slice of rocks of the Nova Lima group bounded on the west by one branch of the major fault represented by the breccia zone, and bounded on the east by another branch of the fault intruded by the dike.

From Feixos to Mutuca no. 2, Macacos quadrangle (N. 11,700 , E. 3,700) the trace of the fault was located on the basis of repetition of strata or omission of strata. The northwest side of the hematite ore body known as Mutuca no. 2 is bounded by a zone of crushed and brecciated phyllite, in turn bounded by dike material. This breccia and dike zone is believed to be the fault zone. The dike, exposed in only one vertical cut in the Mutuca no. 2 area, could not be mapped. It seems likely, however, that the dike may follow the fault zone for a considerable distance.

Northeast of Mutuca no. 2 the fault cuts off the Batatal and the Moeda formations. It cannot be traced farther northeast, because the rocks on both sides of the fault are without marker beds.

A sheared and crushed zone exposed along BR-3 from the cut through the Serra do Curral south to the bridge and beyond is attributed to crushing and deformation caused by the thrust plate as it moved north over this area. The thrust plate has since been eroded southward to the vicinity of Mutuca no. 2 .

\section{MINOR FEATURES}

Bedding commonly is masked or obliterated by schistosity in rocks of the Rio das Velhas series. Bedding 
and cleavage are almost parallel in most exposures where both can be measured; however, exceptions occur even to the extent that the structures are almost at right angles to each other. A photograph of one such occurrence is shown in figure 26.

In rocks of the Minas series, on the other hand, bedding is the dominant planar structure. An exception to this rule is found in the Sabara formation north of the Serra do Curral, where contact metamorphism dur-

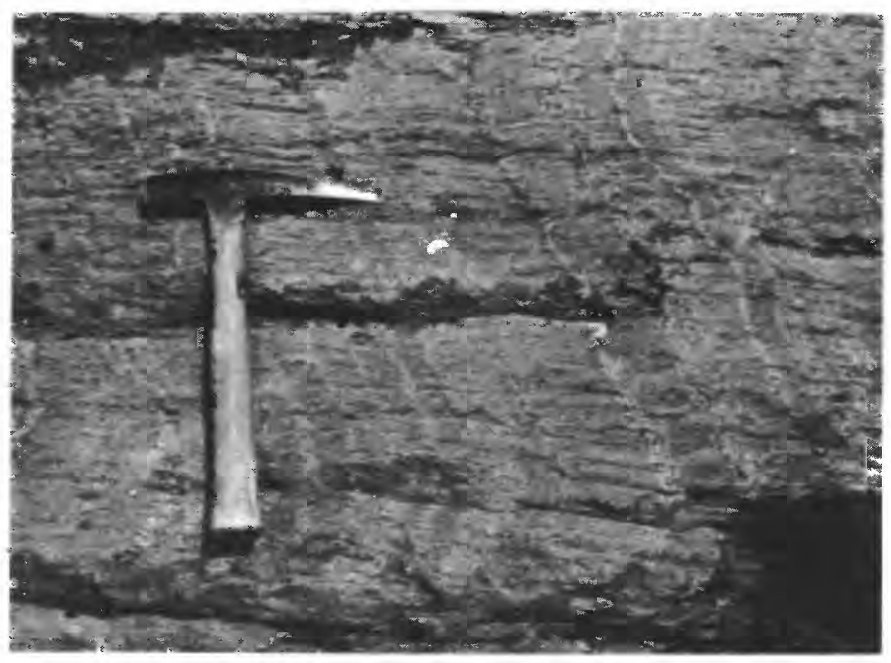

Frgure 26.-Bedding and cleavage in phyllite of the Rio das Velhas series near contact with Minas series, Macacos quadrangle (N. 1,700, E. 700). ing the intrusion of granite has in large part obliterated the primary structure. Locally, shearing and shattering near fault zones also has obliterated bedding.

The rocks of both the Nova Lima group and of the Minas series have had a strong to weak lineation imposed on them; it is widespread, but of sporadic occurrence. This lineation is a regional structure of considerable geologic importance. Several authors, Henwood (1871, p. 211, 239, 323), Guild (1957, p. 33), Gair (1958, p. 44), Dorr and Barbosa (1963) consider that it controls or influences the location or orientation of certain ore deposits. It is caused by parallelism of fold axes, cleavage intersections, and elongate minerals and pebbles. Locally, as in many places in the Serra da Gama, the Cauê itabirite has been plastically deformed to such an extent that only lineations resulting from parallelism of axes of small folds can be measured.

All the rocks in the area are jointed, but only exceptionally prominent joints and joint sets have been recorded on the quadrangle maps. No regional parallelism has been observed in the joint sets.

Closely related to joints, but different by definition, are tiny faults with displacements measured in millimeters. Probably these occur in most or all rocks of the area, but they are best exposed in underground workings, many ofwhich are in Cauê itabirite. An example of en echelon microfaults is shown in figure 27.

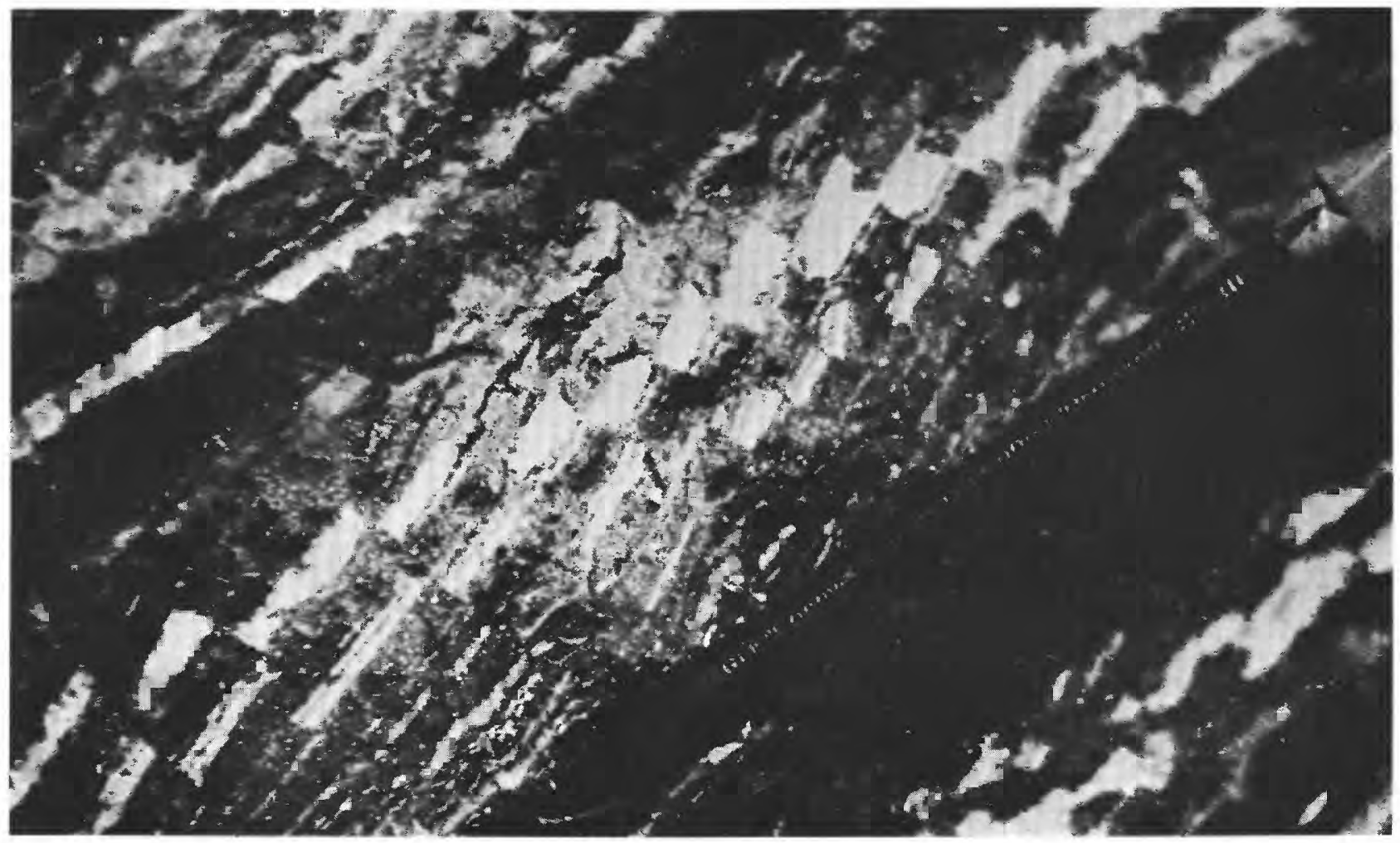

FIGURE 27.-En echelon microfaults in itabirite. Aguas Claras, adit 6, at 60 meters. White is powdery quartz, black is soft hematite. 
PERIODS OF DEFORMATION

Before deposition of the Minas series, the Rio das Velhas series was subjected to major orogeny so that some beds were sharply overturned. Another major orogeny occurred in post-Minas time, forming the anticlinorium with its subsidiary synclines. The thrust faults and tear faults probably developed during the later stages of this orogeny. Granitic intrusion and granitization probably occurred at this time also. It is not known whether the cross-faults and normal faults were formed near the close of this period of deformation or whether they formed during a later period.

\section{ECONOMIC GEOLOGY}

Deposits of iron ore, bauxite, clay, asbestos, gold, and manganese occur in the area discussed in this report.

\section{IRON ORE}

The iron ore is by far the most important mineral commodity. It is of high grade, consists of hematite, both compact (hard) and pulverulent (soft), and occurs in masses ranging in size from only a few tons to several hundred million tons. In addition to the high-grade hematite ore, large and valuable deposits of hematite boulders and rubble, soft itabirite, enriched itabirite, chapinha, canga, and canga rica occur. All the large iron-ore deposits are in, or have been derived from, the Cauê itabirite. A few small ore bodies occur in the Gandarela formation.

\section{TYPES OF IRON ORE}

From a genetic viewpoint, iron ore deposits of this area can be divided into three classes: Replacement bodies of high-grade hematite in Precambrian bedrock; softened Precambrian itabirite; and surficial deposits formed through weathering of iron-rich Precambrian rocks.

High-grade hematite ore in the Quadrilatero Ferrífero is defined as ore that contains more than 66 percent iron on a dry basis.

\section{REPLACEMENT ORES}

The high-grade hematite ore of the replacement bodies ranges in texture from extremely hard, dense, and fine grained to pulverulent. The chemical composition is relatively constant; the high-grade hematite contains from 66 to almost 70 percent iron, and from 0.02 to 0.06 percent phosphorus.

The physical nature of the ore is important from an economic standpoint. In hard ore, drilling and blasting costs are large; in processing soft or pulverulent ore, sintering, pelletizing, or other methods of aggregation are a cost factor. Most ore bodies contain both physical types of ore as well as mixtures of both.
High-grade ore is divided into four physical types: 1. Hard; more than 75 percent is plus half an inch. 2. Medium hard; 75-50 percent is plus half an inch. 3. Medium soft; 50-25 percent is plus half an inch. 4. Soft; less than 25 percent is plus half an inch.

In surface mapping, only three types are practicable. The medium hard and medium soft are combined to form the intermediate.

It should be emphasized that all the high-grade hematite ore is gray, differing in degree of compaction but not in color. Soft high-grade hematite ore in the Quadrilátero Ferrífero is gray and earthy. All specimens of hematite, compared with the standard color chips of the National Research Council Rock Color Chart, are some shade of medium, neutral gray, with no tinge of blue.

In addition to the high-grade hematite ore there is much hematite that contains between 60 and 66 percent iron that should be considered potential ore. Still larger amounts of itabirite contain from 55 to 60 percent iron, and there is even more soft itabirite that contains less than 55 percent iron. It has been shown (Dorr, 1951) that these materials could be easily concentrated to a product containing over 65 percent iron.

COMPOSITION OF THE ORE BODIES

The high-grade ore bodies consist almost entirely of gray hematite. A few percent of magnetite may be present locally in some deposits, and most deposits contain some limonite near the surface. All other minerals generally constitute less than 5 percent of the ore bodies.

Hematite.-Pure hematite contains 69.94 percent iron and 30.06 percent oxygen. Many analyses of highgrade ore approach this maximum. Dorr and Barbosa (1963) report that a shipload lot of 9,120 tons of hematite from Itabira was analyzed by the buyers and found to contain 69.91 percent iron, 0.024 phosphorus, and 0.38 water.

Soft ore under the microscope can be seen to consist of tiny grains and plates of transparent, ruby-red hematite. The transparency of many of the grains makes it possible to see that no magnetite is included, yet the grains are magnetic and polarized. The grains immersed in index liquids can be oriented by a magnetic field. Reversing the magnetic field causes all but the smallest grains to turn 180 degrees. The smallest grains, one micron or less in diameter, are in constant erratic motion called Brownian movement. At this grain size, molecular motion has more effect on the hematite than does the magnetic field. Magnetic polarity of soft hematite can further be demonstrated with a test tube about three-quarters full of dry, soft ore. The randomly oriented grains in the tube are, in mass, 
nonmagnetic and do not affect a compass needle. If the tube is shaken and tapped in the magnetic field of a large magnet, enough of the grains become alined with the magnetic field so that the tube of hematite acts as a bar magnet.

Alinement and nonalinement of the individual grains of hematite may be part of the explanation as to why some hematite outcrops are magnetic and others are not.

Magnetite.-Magnetite is visible in about 25 percent of the polished sections examined. Generally only a few grains are present, but in one specimen 40 percent of the rock was magnetite. Figure 28 shows magnetite partially replaced by hematite.

Quartz.-Quartz is not visible in most specimens of hard hematite ore, even with a hand lens. Under the microscope, a few scattered grains of quartz can be seen in, or adjoining, pore spaces in some polished sections of hematite.

Talc.-In most ore bodies, talc is rare or absent, but in a few deposits joints, shears, and bedding planes are covered with talc. Tiny vugs, also, are lined with this mineral.

Phosphorus.-All of the ores contain some phosphorus; the high-grade hematite generally contains less than 0.05 percent, but it may contain much more near the surface. The mineral, or minerals, containing phosphorus, has not yet been identified but some micron-sized inclusions within quartz grains in itabirite may be tiny apatite crystals.

Argillaceous material.-In the high-grade hard hematite, argillaceous material occurs only in joints

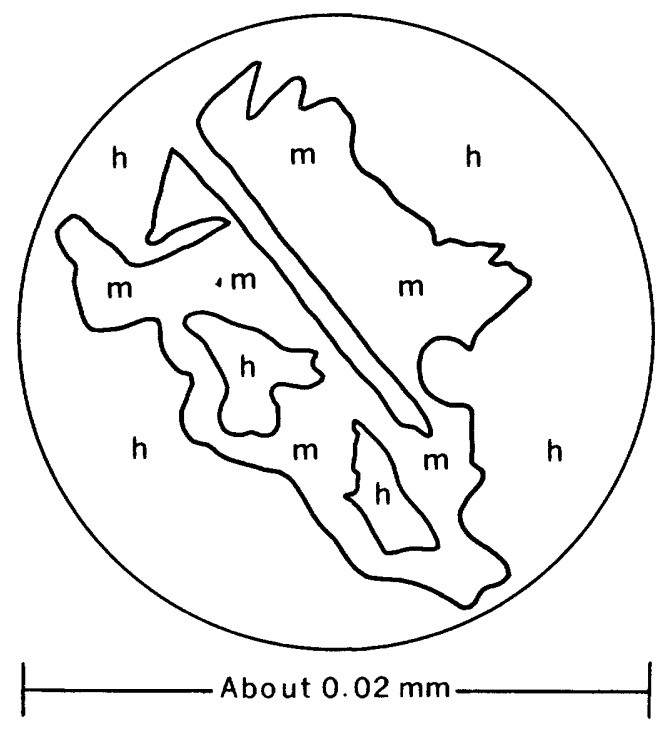

FIgURE 28.-Freehand sketch showing hematite (h) replacing magnetite $(\mathrm{m})$; specimen from Águas Claras; from part of the field of view of a microscope at magnification $485 \times$. and fractures. This may also be true in the soft ores but it is less easy to demonstrate.

Some material mapped as "red clay" has been identified as a mixture of finely divided hematite and limonite. This material may represent dikes that have been entirely replaced by iron minerals.

Pyrite.-Sulfur is generally present in the highgrade ores but in such small quantities that it can be determined only in special analyses. Only one specimen of hard hematite with visible pyrite has been found. It was from a boulder on the north slope of Jangada in the Ibirite quadrangle. Analysis of the sample by Eleonora Leitão de Carvalho of the Laboratório da Produção Mineral was recorded in Bulletin 12900 dated August 9, 1955. The results of the analysis are as follows:

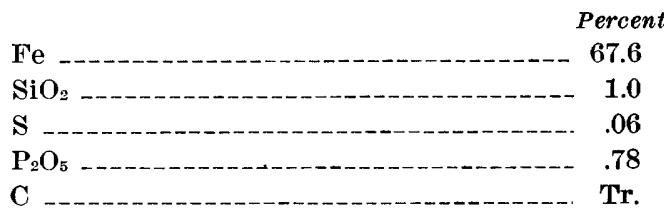

MICROTEXTURE OF THE HEMATITE

The microtexture of the hard hematite ore in the area of this report is remarkably uniform. Similar textures and grain sizes were observed in 13 polished sections, from deposits at Águas Claras in the Belo Horizonte quadrangle, from Jangada in the Ibirité quandrangle, and from Mutuca no. 2, Capitāo do Mato Norte, and Serra da Gama in the Macacos quadrangle. In each, the hematite has a mosaic texture and shows very little schistosity. The grain size in most specimens ranges from 0.02 to 0.04 millimeter, but in one specimen from Aguas Claras the grain size ranges from 0.02 to 0.08 millimeter. The mean size of hematite grains in all specimens studied is a little less than 0.03 millimeter. The mean grain size of soft hematite ore is about 0.02 millimeter.

Although much of the hard hematite appears dense and nonporous in a hard specimen, considerable porosity is visible under the microscope. The mean pore size is the same as the mean grain size of the hematite. Exceptionally large pores appear to be "clusters" of smaller ones.

Quartz grains are present in about one-third of the polished sections. In each, the quartz grains occur in pores, most commonly in the larger pores-the pore "clusters," so that each quartz grain is to a great extent separated from hematite by pore space. This suggests that the hematite-quartz contact is a locus of greater solubility of one or both of the minerals.

A conspicuously banded specimen of ore from Águas Claras shows, in polished section, no difference in grain size of the hematite from one band to another. The 
banding is visible because certain bands have much more pore space than others. Dorr and Barbosa (1963) have shown that the porous bands represent the original quartz bands of itabirite.

$$
\text { ORIGIN OF THE ORE }
$$

Harder and Chamberlin (1915) believed that the high-grade hematite ores were uncommonly thick sedimentary beds of iron-bearing material-comparable to the iron-rich laminae in itabirite, but much thicker. Some of the compact beds of hematite in itabirite, 10 to 20 centimeters thick, may be of this origin, but the large hematite bodies that locally cut across the bedding of the itabirite cannot be sedimentary. This has led the present author, as well as most recent writers, including Dorr, Guild, and Barbosa (1952), and Guild (1953), to conclude that these ore bodies have been formed by metasomatic replacement of the quartz layers in itabirite by hematite leached from a large volume of nearby itabirite. Dorr, Guild, and Barbosa (1952) pointed out that the volume of ore is small compared to the vast volume of itabirite, and that leaching of a small percentage of iron from a large volume of itabirite could furnish enough iron to form the ore bodies without noticeably impoverishing the itabirite.

Hypogene fluid or heated water is considered to be the agent whereby iron was leached from itabirite, transported to the site of a potential ore body, and metasomatically replaced the quartz layers in itabirite.

Guild (1957, p. 57) thought that "the solutions may have been ground water, heated by deep circulation or by proximity to magmatic intrusions, as has been suggested by Gruner (1937) for the Lake Superior ores, or perhaps connate water driven from the sediments during deep burial and metamorphism." Dorr and Barbosa (1963) favor the hypothesis that the active agent was hypogene fluid. The present writer believes that either hypogene water or circulated ground water could have formed the ore bodies but that high temperature has not been proved to be necessary.

The last statement is based, partly, on evidence that ground water has leached small amounts of hematite from some hard ore to form soft ore and that quartz is soluble in ordinary rain water and ground water. Furthermore, quartzite outcrops have, in many places, weathered to sandstone or even to sand. An example is the Taboões quartzite which is quarried for sand in several localities. Another example of leaching of silica by ground water was seen in Mannesmann adit 1 (see fig. 29) where soft red itabirite above is sharply separated from black and white itabirite below. Analysis of the two materials (see table 10 below) shows that the red itabirite contains less than half as much $\mathrm{SiO}_{2}$

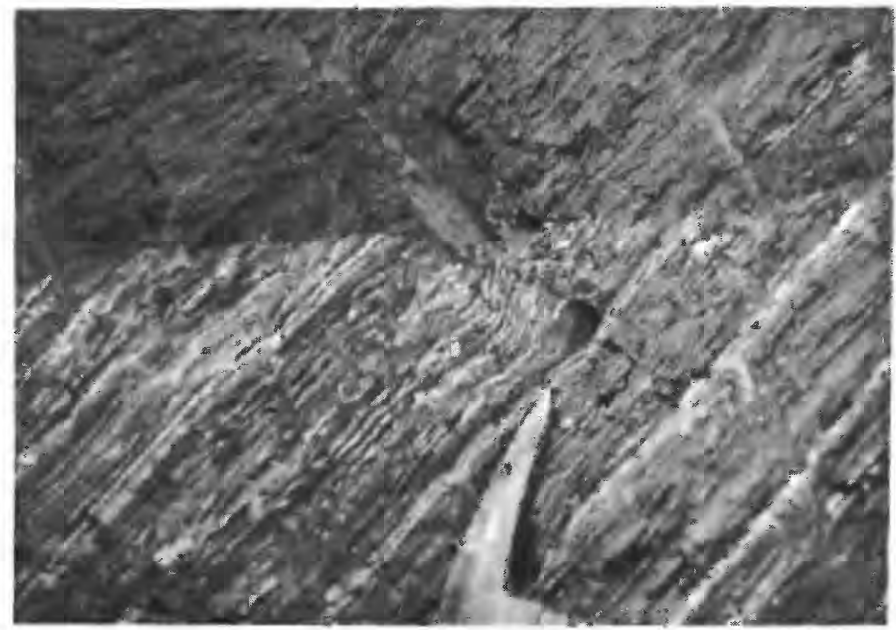

FigURE 29.-View showing line of demarcation between soft red itabirite above and black and white itabirite below. The view is about 20 meters below the surface in Mannesmann adit 1, Serra da Mutuca, Macacos quadrangle.

as the black and white itabirite, a result of leaching by ground water.

It seems well established that cool ground water can dissolve both hematite and quartz, but no direct evidence has been found in the Quadrilátero Ferrifero that suggests cool water has deposited hematite. That the temperature of formation of the hematite bodies may have been low to moderate is suggested by the fact that impure dolomite occurring near hematite ore bodies has been only mildly metamorphosed.

Other evidence, however, may indicate a higher temperature of formation of the ore bodies. The rare occurrence of tiny flakes and crystals of talc, chlorite, pyrite, and pyrophyllite in hard hematite may suggest formation at an elevated temperature, even though individually talc, chlorite, and pyrite are not diagnostic of high temperature, as they are known to occur as secondary minerals in unmetamorphosed sedimentary rocks. Pyrophyllite, however, is generally agreed to be of hydrothermal origin, and if it formed contemporaneously with the hematite it is evidence for a relatively high temperature of hematite deposition.

Perhaps such conflicting evidence indicates that the ore forming process could take place over a relatively wide range of temperature, and that mechanical factors such as pressure differential, rate of fluid motion, and porosity were the prime controls in the formation of the hematite ore bodies.

TABLE 10.-Analyses of the itabirite shown in fig. 29 [Analyst: Aida Espinola, Departamento Nacional da Produção Mineral, Bull. 13486]

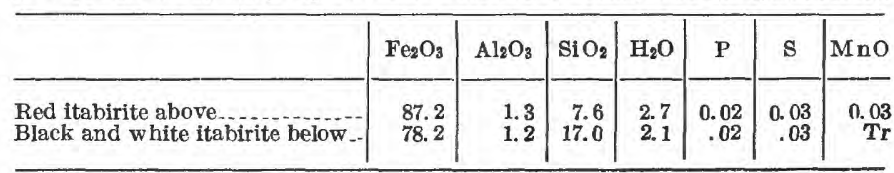


Guild (1957, p. 57) "believes that structural control was the most important factor in the localization of replacement and that the chemical nature of the formation played a secondary role."

Dorr and Barbosa (1963) consider that the hematite deposits were formed by metasomatic replacement of siliceous itabirite, and to a minor extent, of dolomitic itabirite by hematite mobilized from the iron-formation by hypogene fluids.

In the Belo Horizonte, Ibirité, and Macacos quadrangles structural control of the ore deposits is not evident. Every ore deposit seems to be in a zone of compression, but so does all the Caué itabirite and other rocks of the Minas series in this area. Águas Claras is in a zone of compression as shown by the fault pattern on the north side of the Serra do Curral. It is also situated on the overturned limb of an anticline. However, the locations of the crest of the anticline and the keel of the conjugate syncline are unknown, and so the position of Águas Claras relative to the major fold is also unknown.

The Mutuca no. 2 deposit in the Macacos quadrangle, is on a thrust fault but the ore probably antedates at least one stage of faulting because much of the hard hematite is brecciated and contains talc and vein quartz in the fractures. (Vein quartz is rarely seen in hard hematite.)

The other ore deposits described in this report have not been related to any particular structural feature, and so no generalization can be made regarding structural control of ore deposition in this area.

\section{SOFT ITABIRITE}

Soft itabirite is not a high-grade ore, but it can be easily concentrated (Dorr and Barbosa, 1963) to yield a product containing more than 65 percent iron. As mining this ore would involve no drilling, blasting, or crushing costs before concentration, and as there are vast tonnages of this material available in the Quadrilátero Ferrífero, there can be little doubt that it is a valuable hematite reserve.

Guild (1957), Dorr and Barbosa (1963), the present author, and most workers in the area agree that soft itabirite is formed by disaggregation of hard itabirite. Details as to the cause of disaggregation and as to the mechanics and chemistry of the process have not been well established.

Guild believes that soft itabirite once contained a small amount of carbonate in addition to the quartz and hematite. The carbonate was dissolved by meteoric water, which became more alkaline and was thus able to dissolve quartz more easily and further disaggregate the itabirite.

Dorr and Barbosa, on the other hand, maintain that disaggregation is caused by leaching of quartz alone and that the primary controls are physiographic position, texture, and time.

The writer considers the presence of a carbonate a likely factor in softening of itabirite, but by no means discounts the factor of leaching of quartz affected by texture and time. Physiographic position is, of course, important in any process related to weathering or to leaching by meteoric water. It is probable that all the factors mentioned have had some effect on disaggregation.

Fragments of dolomitic itabirite when leached in dilute acid do become soft itabirite or chapinha.

Under the microscope, at a magnification of $\times 750$, it can be seen that quartz in thin sections of hard itabirite and quartz grains from soft ittabirite both contain a few minute carbonate crystals (in addition to at least seven other unidentified substances). This indicates that the carbonate and quartz crystallized together. With this evidence, it is possible that carbonate was deposited locally in relatively large concentration, so that much of it crystallized between quartz grains as well as within them. Subsequent leaching of this carbonate could result in disaggregation of the rock. Where only small amounts of carbonate were present, evidently it was surrounded by recrystallizing quartz and very little crystallized between quartz grains.

Dorr and Barbosa (1963) believe that much of the hard itabirite now exposed at the surface particularly in steep canyons is typical, fresh itabirite and consider it to be the mother rock from which soft itabirite was derived by leaching of silica.

Solution of quartz is certainly involved in the softening of itabirite as shown in figure 29, and the accompanying table on page D43. The writer cannot concede, however, that hard itabirite exposed at the present surface represents "presoft" itabirite. The writer believes that present hard itabirite (or its possible preweathering form) differs in some unknown way from the mother rock of soft itabirite. This conclusion is based on the following evidence and reasoning:

1. Beds of hard itabirite occur in soft itabirite and occupy such a similar physiographic position to that of the soft that they should have been acted upon by the same agents and processes.

2. No evidence has been found to suggest that these beds of hard itabirite occur in a structural position where they would be subjected to a different degree of tension, compression, shearing, or other deformation than the adjoining soft itabirite.

3. Alternating beds, each a few centimeters thick, of hard and soft itabirite occur as much as 200 meters below the surface. It is difficult to find a reason 
why some itabirite should remain hard and some should have been softened if both were originally identical. No other conclusion seems possible than that some beds or lenses of itabirite were amenable to softening because of some difference in mineralogic composition, texture, arrangement of minerals, or chemical composition. Thus hard itabirite might lack easily soluble minerals whereas soft itabirite might once have contained such minerals. The near lack of carbonate and other soluble minerals in present hard itabirite in no way refutes the hypothesis that there were appreciable amounts of such minerals in most soft itabirite prior to weathering.

It is conceivable that soft itabirite originally may have had a different texture than present hard itabirite, and that the fabric of the "pre-soft" itabirite was relatively permeable in comparison to the fabric of the precursor of present hard itabirite, thereby permitting the softening of the one rock, but not of the other, by solution.

Differences in both the arrangement of minerals and the chemical composition between "pre-soft" itabirite and the forerunner of present hard itabirite may have controlled the softening process. The following evidence is to be considered:

1. Hard hematite has been leached by ground water to form pulverulent ore.

2. Soft itabirite is generally richer in iron than hard itabirite.

3. Some polished sections of hard hematite contain quartz grains nearly isolated from the hematite by pore space. Contact between quartz and hematite is almost tangential. This suggests solution of quartz or hematite, or both, along the quartzhematite contact.

4. In other formations, quartzite has been weathered to sand through solution of quartz by ground water. Strong, almost conclusive, evidence shows that both compact masses of hematite and essentially pure quartzite have been leached to form powder or sand. Presumably this action occurs along grain boundaries. Truly bimineralic itabirite (iron oxide and quartz) could be disaggregated by the solvent action of ground water along the grain boundaries of each component. Quartz is more soluble than the hematite, as shown by layers of disaggregated quartz and of compact hematite in partially softened itabirite.
Evidence therefore indicates that hard itabirite can be softened by leaching of hematite and quartz, but this does not explain the present, seemingly random, surficial distribution of hard and soft itabirite. There must have been some original difference within the itabirite to give rise to the present hard and soft varieties. This difference may have been in carbonate content, in grain size or other textural features, or in distribution of hematite and quartz in the rock, or in a combination of all three.

\section{SURFICIAL ORES}

Genetically, the surficial ores can be classified into two major types, ore formed in place through weathering of Precambrian bedrock and Tertiary to Quaternary iron-rich sediments and sedimentary rocks derived from Precambrian rocks. Ore derived in place from weathered Precambrian bedrock is of two kinds, chapinha and surficially enriched itabirite. The Tertiary and Quaternary iron-rich sedimentary materials include indurated rock consisting of canga and canga rica, and unconsolidated deposits, consisting of iron ore rubble, cobbles, and boulders. These ores are valuable for several reasons:

(1) They are all surficial and require little or no development before actual mining, (2) their extent is visible at the surface or can be determined by shallow pits and trenches, and (3) the unconsolidated ores and chapinha and some surficially enriched itabirite occur in pieces of ideal size for use without drilling, blasting, or crushing.

\section{CHAPINHA}

Chapinha (pronounced sha-peén-yah and meaning "little plate") is weathered itabirite in which the hematite layers, althrough broken into thin plates, have remained hard and coherent while the quartz layers have been disintegrated to fine sand. Beneficiation involves only the removal of sand from the plates of hematite by screening. Chapinha is a valuable ore for charcoal blast furnaces, because the thin plates form a relatively light ore that does not crush the charcoal.

Natural outcrops of chapinha are scarce because of its friability. Its presence may be indicated by thin plates of hematite in sandy soil on grassy slopes, but in most places, pits or trenches are necessary to make certain that chapinha is present and the most of the hematite occurs in plates sufficiently coherent to stand the screening operation. Chapinha is gradational into both soft and hard itabirite, both of which require more elaborate beneficiation than does the chapinha. 
An analysis of chapinha from a mine at Belo Horizonte, N. 3,600, E. 7,000 by Cassio Mendonça Pinto, Laboratório do Departamento Nacional da Produção Belo Horizonte follows:

\begin{tabular}{|c|c|c|c|}
\hline \multicolumn{3}{|c|}{ Percent } & Percent \\
\hline $\mathrm{SiO}_{2}$ & 18.5 & & 0.03 \\
\hline $\mathrm{Fe}$ & 52.8 & $\mathrm{H}_{2} \mathrm{O}^{+}$ & 5.9 \\
\hline $\mathrm{Al}_{2} \mathrm{O}_{3}$ & $<.4$ & Total $^{1}-$ & 99.9 \\
\hline Mn & & & \\
\hline
\end{tabular}

\section{SURFICIALLY ENRICHED ITABIRITE}

Itabirite may be enriched near the surface by the leaching of quartz and by replacement of quartz by limonite. The resulting product is a relatively light, porous ore containing 60 percent to 66 percent iron suitable for charcoal furnaces.

Surficially enriched itabirite may extend only a few centimeters below the surface or it may extend downward as much as 10 meters. Physiographic position is certainly one of the controlling factors as to depth of enrichment. An adit at the Barreiro or Mutuca no. 1 deposit in the Macacos quadrangle exposes enriched itabirite at a depth of 10 to 20 meters below the surface, but the adit is under and almost parallel to a stream course, in a position where an unusual amount of surface water has been available for leaching of quartz.

Surficial enrichment of itabirite is illustrated in figure 29 and the accompanying analyses on page $\mathrm{D} 43$.

\section{CANGA}

Canga ranges in composition from high-grade iron ore consisting of angular blocks of hard hematite with only enough limonite to cement the blocks together (canga rica), through conglomerate-breccia consisting of fragments of itabirite and hematite with either little or much limonite cement (ordinary canga), to material consisting only of limonite cementing ferruginous soil (chemical canga) which is not considered to be ore.

Ordinary canga occurs as a capping over much of the itabirite, and commonly extends downslope over adjoining formations. Although relatively high in phosphorus it is used in local charcoal blast furnaces because of its porosity.

The mean thickness of canga is probably about 2 meters, but the maximum thickness may be as much as 20 meters. Its iron content probably averages more than 50 percent iron but may be higher or lower depending upon the degree of leaching, and proximity to high-grade ore bodies. The more extensive canga areas are indicated on the quadrangle maps.

\section{CANGA RICA}

Canga rica is the highest grade of the canga ores. It commonly contains 66 percent to 68 percent iron.
Genetically, it is a relatively recent rock formed by cementation of detritus from outcrops of high-grade hematite ore. Canga rica indicates that hard highgrade hematite ore exists or existed either beneath it or uphill from it. Its range in thickness is similar to that of ordinary canga.

Canga rica grades into ordinary canga and so is difficult to delimit during mapping. Canga that is derived mostly from high-grade soft or intermediate hematite may appear similar to canga derived from itabirite. Consequently, large areas shown on the maps as ordinary canga may contain more than 66 percent iron, and only the canga consisting of cobbles and boulders of hard hematite is shown on the maps as canga rica.

The larger areas of canga rica are shown on the detailed maps.

$$
\text { RUBBLE ORE AND ROLADOS }
$$

Unconsolidated deposits of hematite and hematiterich material occur in talus cones, alluvial fans, and outwash plains. The source rock is commonly the physiographically higher Canê itabirite. In this report these deposits are classified and described as two separate types, rubble ore and rolados, even though these are actually the extremes of a gradational series.

Rubble ore consists of more or less angular pebbles and cobbles of compact hematite mixed with ferruginous soil. It generally occurs in alluvial cones, fans, and outwash plains. The hematite pebbles are not necessarily derived from outcrops of hard hematite ore, but may be remnants of itabirite fragments that have been leached of quartz during transportation down slope. The ferruginous soil commonly is finely divided hematite with minor amounts of clay and fine-grained quartz. Some rubble ore may contain more than 60 percent iron. After screening, the product contains about 65 percent iron and is of ideal size for blast furnace feed.

Rubble deposits may be extensive but rarely can be mapped without much pitting and sampling. Probably the largest deposit of rubble ore in these three quadrangles lies along the north side of the Serra da Jangada in the Ibirite quadrangle. It is being actively mined at several levels on the slope. Exposed thicknesses range from 1 meter to 4 meters. The extent has not been outlined but there is promise of a large, easily mined ore deposit. The surface of this deposit appears similar to any slope strewn with itabirite fragments, and without the exposures made in exploiting the deposit, its existence could only be predicted from the knowledge that talus and rubble should be expected below an outcrop of massive hard hematite.

A small, but rich, rubble deposit occurs at Taquaril in the eastern part of the Belo Horizonte quadrangle. Here also there is little indication of its existence on 
the undisturbed surface. Rubble ore should be expected below any outcrop of hard hematite. Fans and valley fill below itabirite should be test-pitted.

Rolados are more or less rounded cobbles and boulders of high-grade, hard hematite on pediments and the lower slopes of mountains. Only the hardest and purest varieties of hematite have survived the crushing and abrasion incidental to transfer down the slope. The rounding has been caused primarily by solution of the sharp corners and secondarily by abrasion. These deposits of generally equal sized cobbles and boulders are spectacular in appearance. Dislodged cobbles ring like metallic iron as they strike other cobbles. The deposits are generally only 1 to 3 meters thick and are relatively small. Areas of rolados are shown on the detailed ore deposit maps.

\section{HIGH-GRADE HEMATITE ORE}

The term "ore" in the description of the areas and cross sections that follow is limited to material containing over 66 percent iron. The cutoff at 66 percent has been chosen because material containing less iron also contains visible quartz. Material with over 66 percent iron may contain a small amount of quartz, but it is not readily discernible and is not abundant enough to cause faint banding.

Indicated ore is hematite above the lowest point of exploration or outcrop. In deposits with no third dimension exposed, indicated ore is expressed in tons per meter of depth. Inferred ore is that which lies between lowest outcrop or point of exploration and 50 meters below that outcrop or point.

Construction of cross sections of the ore bodies is based on the fact that the long dimension of many hematite deposits is virtually concordant with the bedding of the enclosing itabirite, as shown by Dorr and Barbosa (1963) in the Itabira district.

Reserves of many deposits were calculated by measuring the map areas with a polar planimeter. The area in square meters was multiplied by a tonnage factor of 4.5 tons per cubic meter to give tons per meter of depth. Reserves of ore bodies of high topographic relief or of ore bodies with subsurface data available were calculated as described for each individual deposit.

\section{TAQUARII}

Two small but high-grade hematite ore bodies occur near the middle of the eastern boundary of the Belo Horizonte quadrangle, in an area known as Taquaril. (See pl. 1, Belo Horizonte quadrangle, and fig. 30, the Taquaril area.) This is an area of intense faulting and folding, and exposures are too poor to permit the working out of the structure in detail. The stratigraphic position of these ore bodies is uncertain. The enclosing rock may be itabirite and dolomitic itabirite of the Gandarela formation, as shown on the maps, or they may occur in a segment of the Cauê itabirite that has been repeated by faulting. The schist and phyllite shown on the detailed map may be weathered dolomitic phyllite of the Gandarela formation overlying the Cauê itabirite, or it may be in part Batalal formation repeated by faulting.

Data concerning these two bodies are as follows:

North ore body :

16,000 square meters.

72,000 tons of hematite per meter of depth.

Estimated hard ore, 30 percent; soft ore, 70 percent.

Observations : maximum relief on ore body is about 30 meters. Downward extension of the ore body cannot be estimated without underground data.

South ore body :

27,000 square meters.

120,000 tons per meter of depth.

Estimated hard ore, 30 percent; soft ore, 70 percent.

Observations: The maximum relief is about 85 meters. Fold axes plunging $30^{\circ} \mathrm{SE}$. suggest that at least part of the apparent thickness indicated by the relief on this outcrop is the result of dipslope.

TABLE 11.-Ore estimate, Taquaril, Belo Horizonte quadrangle

\begin{tabular}{|c|c|c|c|}
\hline Ore body & $\begin{array}{c}\text { Indicated } \\
\text { (tons per } \\
\text { meter depth) }\end{array}$ & $\begin{array}{c}\text { Inferred } \\
\text { (tons to } 50 \\
\text { meters depthl) }\end{array}$ & $\begin{array}{c}\text { Estimated } \\
\text { percent of } \\
\text { plus one-half } \\
\text { inch }\end{array}$ \\
\hline $\begin{array}{l}\text { North } \\
\text { South.-. }\end{array}$ & $\begin{array}{r}72,000 \\
120,000\end{array}$ & $\begin{array}{l}3,600,000 \\
6.000,000\end{array}$ & $\begin{array}{l}30 \\
30\end{array}$ \\
\hline Total ${ }^{2}$ & 190,000 & $9,600,000$ & \\
\hline
\end{tabular}

${ }^{\mathrm{I}}$ Not considering topography.

2 Estimates rounded off to two significant figures.

\section{ÅGUAS CLARAS}

One of the major high-grade hematite deposits in the Quadrilátero Ferrífero lies about 5.5 kilometers southeast of the center of the city of Belo Horizonte in the part of the Serra do Curral known as Águas Claras. The term Águas Claras was originally applied only to the watershed of the Corrego das Águas Claras, the stream from which the city of Nova Lima obtains its water supply. In reference to mineral deposits, however, and in this report "Águas Claras" is used in a broader sense to designate the hematite deposit on both the north and south slopes of the Serra do Curral in an area extending from about Belo Horizonte N. 4,400, E. 8,600 to Belo Horizonte N. 6,100 E. 10,900 . 


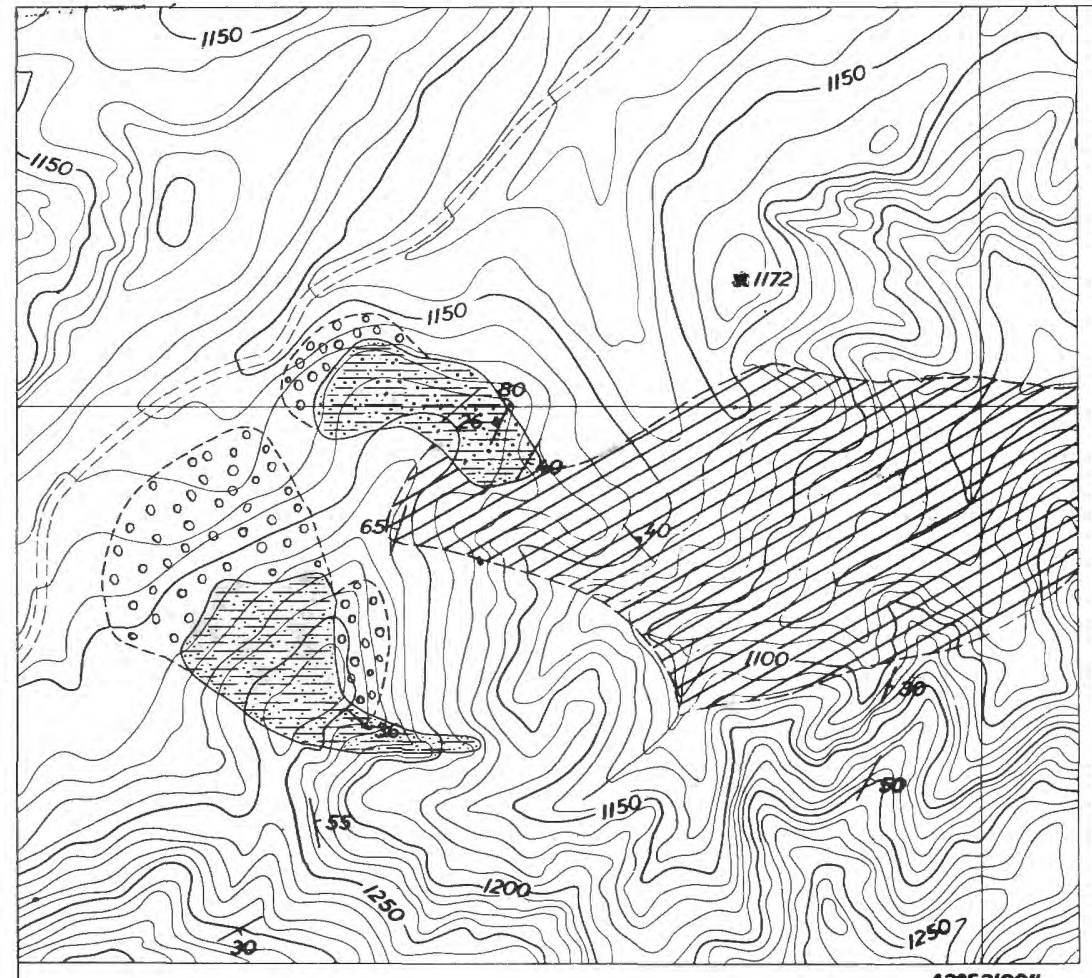

$43^{\circ} 53^{\prime} 00^{\circ}$

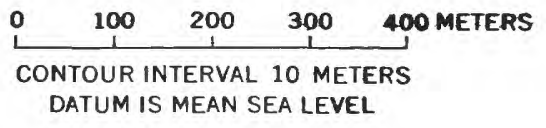

DATUM IS MEAN SEA LEVEL

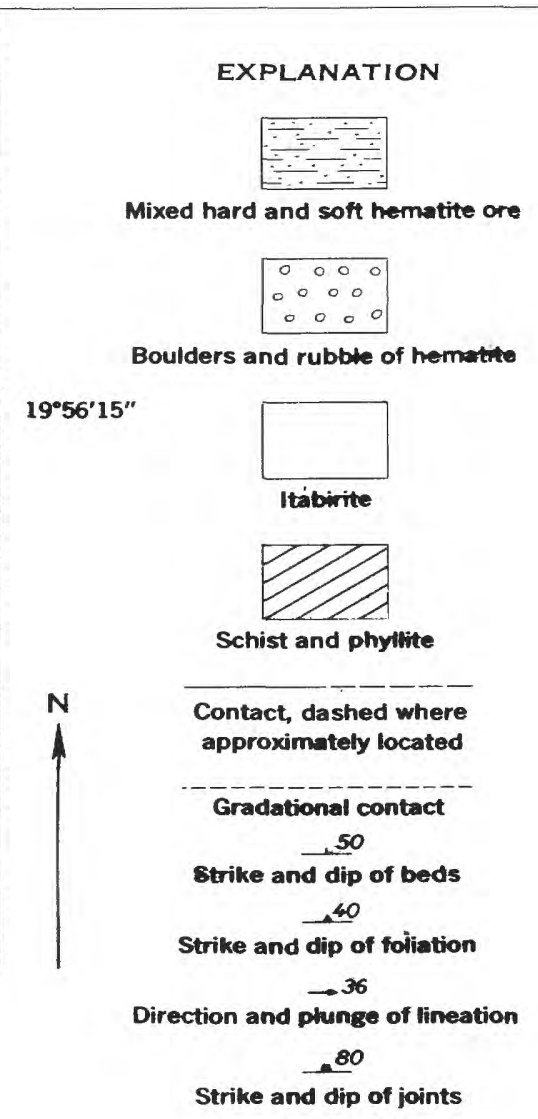

Geology by Joel B. Pomerene, 1956

Topography by Serviços Aerofotogramétricos Cruzeiro do Sul, S.A., 1951

Figdre 30.-Geologic map of the Taquaril area, Belo Horizonte quadrangle, Minas Gerais, Brazil.

The large-scale map of Aguas Claras (pl. 8), which was made photogrammetrically by Geofoto S. A. using new photographs (1956), was at a scale of $1: 2,000$ with a 2-meter contour interval. The St. John del Rey Mining Co. made an accurate survey of the area for the dual purpose of checking the accuracy of the map and to furnish the author with accurately located points to aid in plotting the geology.

The geology was mapped by the author, partly by planetable and alidade and partly by plotting on enlarged photographs. The data were transferred from the enlarged photographs to the base map by Geofoto S. A. using a Kelch plotter. The planetable data were plotted directly on the base map.

Analyses are those furnished the writer by the St. John del Rey Mining Co. Many of the samples were collected by R. A. Ledward of the firm Mackay-Schnellman, consultants to the St. John del Rey Mining Co. in 1954-55. Surface samples and the samples along the north scarp were taken by the company in 1913 .
The locations of cross sections (pl. 8) were chosen so that adits (pl. 9) and drill holes would, as nearly as possible, be in the planes of the sections. The greatest distance that exploration data were projected into the plane of a section was 75 meters (the southern end of No. 2 tunnel $)^{4}$. All cross sections are parallel but they are not equally spaced. Beginning in the southwestern part of Águas Claras, the sections are designated $A-A^{\prime}$ to $H-H^{\prime}$ successively to the northeast. Areas adjoining sections and between sections are similarly designated from (1) in the southwest to (10) in the northeast.

Computation of hematite reserves in areas (4) through (9) involved measuring the area of hematite shown on the sections with a polar planimeter. The average area in each pair of sections was multiplied by the distance between sections, giving volume of hema-

\footnotetext{
${ }^{4}$ At the time of writing (1958) there is actually only one tunnel; the others are adits. Local usage is followed herein and all exploration adits and tunnel are given the prefix " $T$ " plus a number.
} 
tite in cubic meters. Multiplying by a factor of 4.5 tons per cubic meter, gives an estimate of the tons of hematite under each of the areas (4) through (9).

No cross section has been prepared along the southwest side of area (1) and this area has an apparently barren zone to the northeast, so the cross-sectional area. of hematite in section $A-A^{\prime}$ was multiplied only by the strike length of the outcrop, and the density factor.

Area (2) has no hematite outcrops, and at the time of computation (early 1958) had no underground exploration. It, therefore, is assumed to be barren.

Tonnage in area (3) was computed from the area of measured hematite in section $B-B^{\prime}$, multipled by the extent of the outcrop southwest of the trace of the cross section. This volume was multiplied by the tonnage factor.

Tonnage in area (10) similarly was computed by multiplying the area of hematite in cross section $H-H^{\prime}$ by the distance to the most northeasterly hematite outcrop, and this volume by the tonnage factor.

It is believed that the tonnage figures determined in this way are too low, and that as development proceeds, more hematite will be proved. This has already been shown by new adits started after this report was written in mid-1958. A new adit about 120 meters east of the portal of T-9 is reported to be in hard hematite ore. An adit near the site of DDH-1 is also reported to be in broken, hard hematite ore. Soft hematite ore has been found in a new adit in area 2 estimated to be barren.

AREA 1

The western part of the outcrop in area 1 consists of contorted, granular, thin-bedded hematite; the eastern part of the outcrop consists of platy hard hematite with one zone of schistose hematite. The hematite outcrop does not extend over the north scarp but extends for some disance down the south slope and may possibly continue down dip underneath the canga.

The highest point of the hematite outcrop is only 33 meters above the lowest point of outcrop. Lacking evidence to the contrary, it has been assumed that the hematite body is essentially concordant with the bedding of the enclosed itabirite. The volume of indicated hematite is the area above 1,330 meters, shown on section $\mathrm{A}$, times the strike length of the outcrop. This volume times the tonnage factor is considered to be indicated ore.

The average iron content of eight samples (fig. 31) in area 1 is 63 percent; the analyses range from 56 percent iron in the southeastern part of the area to 66.4 percent in the southwestern part. A series of 21 samples were taken in 1913 at 6.1 meter intervals down the north scarp. The uppermost six had an average iron con- tent of 59.7 percent, the next sample down the slope showed 67.5 percent iron. The next 5 samples contained an average of 52.5 percent iron, and the lower 9 samples an average of 47.4 percent. The iron content of the itabirite varies inversely with distance from the hard hematite ore.

$$
\begin{array}{lc}
\text { Reserves, area } 1 & \text { Tons } \\
\text { Indicated ore (above lowest outcrop) } & -120,000 \\
\text { Inferred ore (50 meters below lowest outcrop) }---- & 230,000
\end{array}
$$

AREA 2

No hematite crops out in area 2; the only rock exposed, other than canga, is medium-soft itabirite on the north scarp and two outcrops of hard itabirite on the south slope in the northeastern part of the area.

Hematite boulders 2 to 5 meters in diameter cover a small area adjoining the southwestern outcrop of hard itabirite.

At the time of mapping (1957) there was no underground exploration in area 2. As no positive evidence was found to indicate a hematite deposit in this area, the area was assumed to be barren. In 1958 an adit was driven north-northwest from about the middle of the canga sheet. This adit penetrated about 50 meters of soft itabirite and about 25 meters of soft hematite ore. Area 2, then, is not entirely barren, and there is a distinct possibility that further exploration will reveal a large tonnage of soft hematite ore.

A series of samples was taken in this area in 1913 at 6.1-meter intervals down the north scarp. Analysis of the uppermost 12 samples showed an average iron content of 56.8 percent. The lower 12 samples contained an average of 45.8 percent iron. The average iron content of 20 surface samples taken from the south slope of area 2 was 62.4 percent. The range in iron content of the samples was from 48.5 percent in the southern part to 69.0 percent in the northeastern part.

\section{AREA 3}

Area 3 was chosen so as to include that part of an outcrop of hematite ore lying southwest of section $B-B^{\prime}$. The ore is highly contorted in the northwestern part of this outcrop. In the southeastern part the ore is broken and probably somewhat displaced. The northeasternmost outcrop of hard itabirite in area 2 extends into area 3. The north scarp is all medium to soft itabirite.

Area 3 is bounded on the northeast by section $B-B^{\prime}$, which is drawn through one of the largest surface exposures of hard hematite ore in Águas Claras. The hard hematite (see sec. $B-B^{\prime}$ ) extends only about 10 meters down the north scarp. Below the lowest exposure of hard hematite, the steep slope is grass covered 


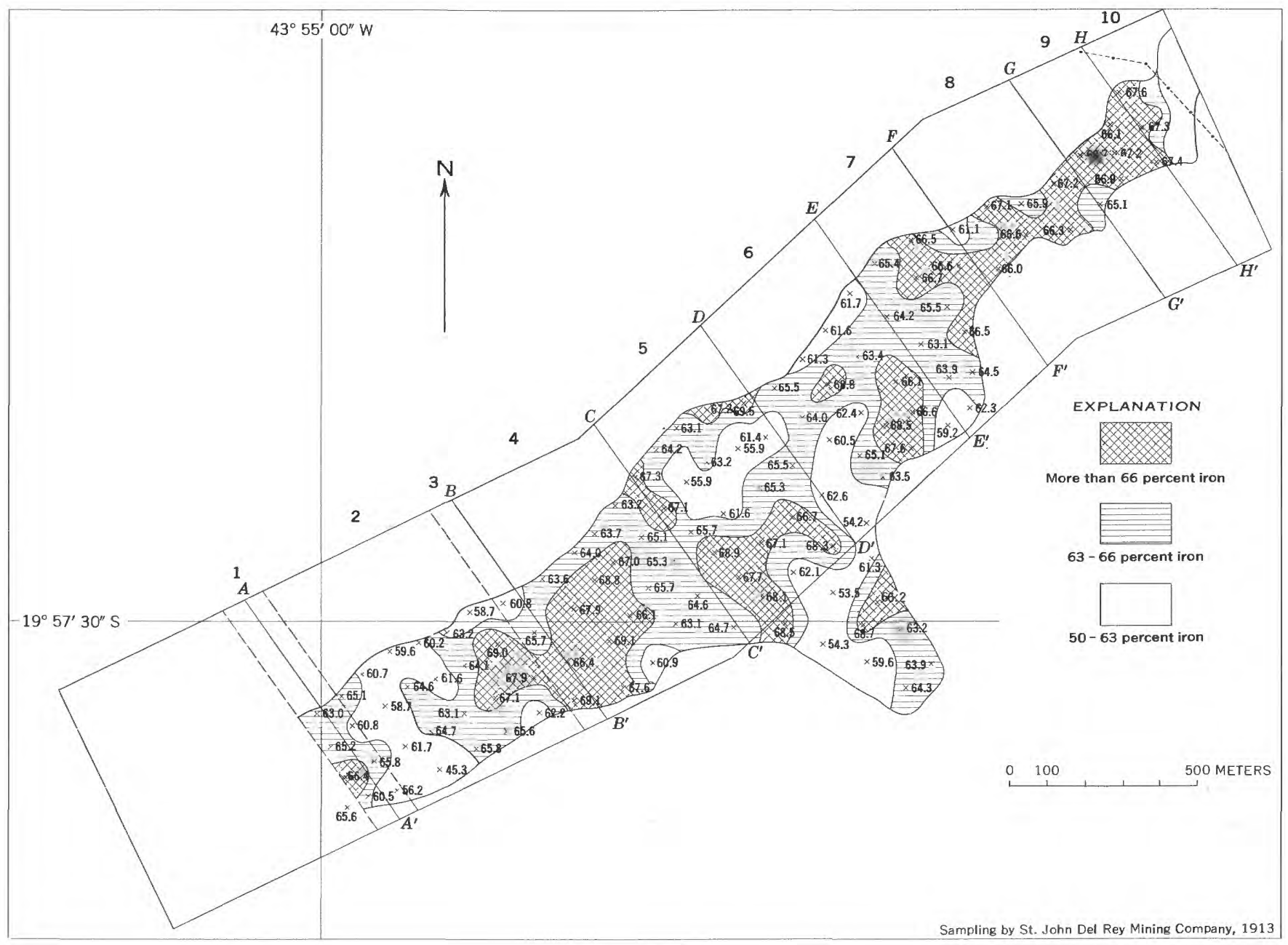

Figure 31.-Sketch map of Águas Claras, showing iron content of surface samples.

for some distance. It is possible, and even probable, that soft hematite underlies part of this slope, but none has been shown in the section nor included in the estimate.

The ore has been projected down dip in the cross section as no evidence for a cross-cutting structure was seen. Hard hematite ore is shown on the section as grading into intermediate, or platy soft hematite ore at depth. This is extrapolation from other sections ( $D-D^{\prime}$ for example) where hard hematite ore is exposed at the surface and soft hematite occurs in the adit below.

The hematite body may extend for some distance south under the canga, but the cross section and estimate are restricted by limits of visible outcrop. Diamond-drill hole No. 1 was reported to have entered schist or phyllite after passing through about 15 meters of canga rica.

An adit being driven at present (mid-1958) from the site of DDH-1 is in blocky hard hematite with wide fissures filled with surface clay, mud, and detritus. It is possible that DDH-1 was in one of these fissures and not in the Batatal formation.

The cross-section area of hematite ore in section $B-B^{\prime}$ above the lowest point of outcrop was measured and multiplied by the distance from the section to the southwest boundary of the area.

\section{Reserves, area 3}

Tons

Indicated ore (above lowest outcrop) 450,000

Inferred ore ( 50 meters below lowest outcrop) _._ 600,000

\section{AREA 4}

Two major and several minor outcrops of hard hematite ore occur in area 4 between sections $B-B^{\prime}$ and $C-C^{\prime}$. Section $C-C^{\prime}$ has underground control as adit $\mathrm{T}-4$ lies in the plane of the section. The large hematite outcrop on the south slope of the serra in the southwestern part of the area consists dominantly of highly contorted hard hematite; one relatively small area in 
the eastern part of the outcrop consists of hard schistose hematite. The other major outcrop is in the eastern part of area 4, terminating in the vicinity of the portal of adit T-4. It consists mainly of massive hard hematite ore, with some contorted hard hematite ore in the western part.

Two outcrops of hard, pink itabirite occur north of the eastern major hard hematite outcrop.

The average iron content of 18 surface samples taken on the south slope in area 4 in 1913 was 65.2 percent.

The north slope of the serra in this area consists dominantly of medium-soft itabirite. A series of samples was taken in 1913 at 6.1 meter (20 foot) intervals down the north scarp. Analyses of the uppermost 8 showed an average iron content of 66.5 percent; the lower 18 samples average 46.5 percent iron. High-grade, soft hematite ore extends for a slope distance of approximately 49 meters below the crest of the serra in the middle part of area 4.

Reserves were calculated by averaging the cross-section area of hematite in section $\mathrm{B}-\mathrm{B}^{\prime}$ above the lowest outcrop and the area of hematite in section $\mathrm{C}-\mathrm{C}^{\prime}$ above adit $\mathrm{T}-4$, and multiplying by the distance between the two sections, giving the volume of hematite in area 4 . This, multiplied by the factor of 4.5 tons per cubic meter, gave tons of indicated ore.

\section{Reserves, area 4}

Indicated ore (above lowest outcrop or explora- Tons tion) -

Inferred ore (projected 50 meters below lowest exploration) $7,000,000$

AREA 5

Several medium-sized outcrops of hard hematite occur on the south slope of the serra in area 5. In addition there are outcrops in the northeastern part of the area that are interpreted as lying above soft ore and mixed hard and soft ore. The hard hematite ore exposed in the southwestern part of the area is granular and contorted, whereas that in the northeastern part is more schistose.

A large outcrop of highly contorted hard pink itabirite occurs in the western part of the area just northwest of a large exposure of massive hard hematite ore.

Analysis of 30 surface samples from the south slope in area 5 taken in 1913 averaged 64.2 percent iron.

The north slope of the serra is all medium to hard itabirite. A series of samples at slope intervals of 6.1 meters showed an average of 51.7 percent iron from the uppermost 12 samples and 43.4 percent iron from the lower eight samples.
Section D-D' has an unusual amount of underground control-one long adit $\mathrm{T}-9$, and two diamond-drill holes, 5 and 6 . The section shows the distribution of the hematite. An extensive exposure of hard hematite ore extends to a depth of almost 100 meters as proved by drill hole 5. Adit T-9, however, passed through almost nothing but soft hematite ore downdip from the hard ore exposed at the surface and in the drill hole.

The area of hematite ore in both sections $\mathrm{C}-\mathrm{C}^{\prime}$ and $\mathrm{D}-\mathrm{D}^{\prime}$ was averaged and multiplied by the distance between them and by the factor, 4.5 tons per cubic meter, in computing the reserves.

\section{Reserves, area 5}

Tons

Indicated ore (above lowest exploration) _-_-_-_-- 21, 000, 000 Inferred ore (50 meters below lowest exploration) _- $12,000,000$

AREA 6

Large outcrops of hard hematite occur along both the southwest and the northeast boundaries of area 6 , and are connected along the crest of the serra. The hematite ore is massive in the northeastern part, and platy to thin-bedded in the middle and southwestern parts.

The south slope of the serra in this area is almost entirely covered by canga except for the exposures of ore already mentioned. One other exception is an outcrop of granular hard hematite about 40 meters west of the portal of adit T-8. The average of 19 surface samples taken on the south slope in 1913 showed 63.4 percent iron. Most of the surface samples were canga.

The north scarp is partly in high-grade soft ore and partly in itabirite. A series of 30 samples were taken down the north scarp at 6.1-meter intervals in 1913. The uppermost 12 averaged 65.7 percent iron; the next lower 12,61.7 percent, and the lowermost six samples averaged 66.7 percent iron. Thus, samples from about 170 meters of slope distance averaged approximately 64 percent. The slope and the dip of beds are almost at right angles to one another so the slope distance approximates the stratigraphic thickness.

Of the rich material on the north slope only the highgrade soft hematite ore near the crest of the serra has been included in the estimate of reserves. In mining, however, material with 64 percent iron cannot be ignored, and so the actual reserves will be considerably higher than estimated.

Reserves were estimated in the same way as in previously described areas.

Reserves, area 6

Indicated ore (above lowest exploration)
Inferred ore ( 50 meters below lowest exploration) - $25,000,000$ 
Two adits were being driven at the time of this writing (mid-1958) approximately along the center line of area 6 . Both encountered intermediate ore under the canga.

AREA 7

Area 7 is bounded on the southwest by section $\mathrm{E}-\mathrm{E}^{\prime}$ which has 1 adit and 2 diamond-drill holes for underground control, and on the northeast by section $\mathrm{F}$ which has 1 adit and 1 drill hole for control.

The only outcrop on the south slope is part of a body of hard hematite ore in the southwestern part, near section $\mathrm{E}-\mathrm{E}^{\prime}$. Although most of this area is canga-covered, adits and drill holes have indicated a large amount of hematite.

The average iron content of 11 surface samples was 65.0 percent.

The north scarp is in high-grade soft hematite ore near the crest and in itabirite rich in iron near the bottom. Analyses of 19 samples taken at slope intervals of 6.1 meters showed an average iron content of 68 percent. The lowermost five samples averaged 60.2 percent iron. The ore in the north scarp, then, averages over 66 percent iron across a slope distance of about 140 meters as measured from the crest of the serra.

Reserves were calculated for this area by averaging the areas of hematite ore above levels of exploration in sections $E-E^{\prime}$ and $F-F^{\prime}$ and multiplying by the distance between sections and by the tonnage factor.

\section{Reserves, area 7}

Indicated ore (above lowest exploration) Inferred ore (50 meters below exploration) $28,000,000$ $17,000,000$

\section{AREA 8}

Only canga and soil over canga can be seen on the south slope of the serra in area 8. Section $F-F^{\prime}$ along the southwestern border includes adit T-6 and DDH 9 ; section $G-G^{\prime}$ to the northeast includes tunnel T-2. The three underground explorations reveal a large amount of high-grade hematite ore.

The north slope of the serra is in soft hematite ore and medium grade to rich itabirite. A series of 23 samples were taken at 6.1-meter intervals (slope distance) down the north face in 1913. The uppermost 14 showed an average iron content of 67.6 percent. The next 5 had an average iron content of 50.5 percent; and the lowest 4 averaged 65.7 percent iron. The average of all the samples in this part of the north scarp was 63.5 percent iron.

The average of seven surface samples taken in 1913 from the south slope contained an average of 65.7 percent iron.

Reserves were estimated as in the areas to the southwest.

$$
\text { Reserves, area } 8 \text {. }
$$

Indicated ore (above lowest exploration)

AREA 9

The south slope in area 9 is dominantly canga rica, but also contains several moderately large exposures of hard hematite ore. In section $G-G^{\prime}$, which forms the southwest boundary of the area, tunnel 2 penetrated almost no hard hematite. The average iron content of six surface samples taken in 1913 was 66.5 percent.

Volume of reserves is based on the average of the cross-section areas of hematite in sections $G-G^{\prime}$ and $H-H^{\prime}$ times the distance between sections.

$$
\begin{array}{cr}
\text { Reserves, area } 9 & \text { Tons } \\
\text { Indicated ore (above exploration) } & 10,000,000 \\
\text { Inferred ore (50 meters below exploration) }--1,000,000 \\
\text { AREA } 10
\end{array}
$$

The estimate of reserves in area 10 is necessarily a guess because there are few surface exposures and no underground exploration. A few outcrops of thinbedded hard hematite occur in a field of fairly rich canga.

Although the north slope is dominantly in itabirite, a small amount of soft hematite ore is exposed.

The reserve estimate was based on the contact of soft hematite ore with itabirite on the north slope. This occurs at almost the same altitude as the sharp break in slope on the south side of the serra. Material above this level was considered as indicated ore.

\section{Reserves, area 10}

Tons

Indicated ore (above lowest outcrop)
Inferred ore ( 50 meters below lowest outcrop) $--\quad 4,000,000$

TABLE 12.-Ore estimates, Águas Claras, Belo Horizonte quadrangle

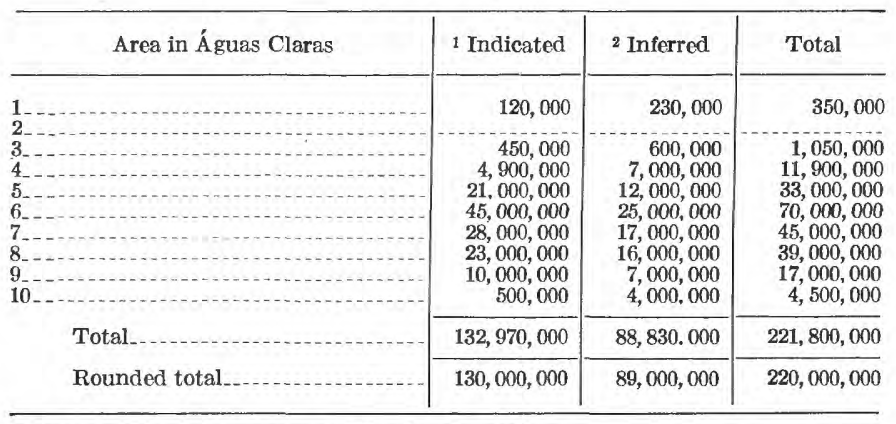

1 Ore above lowest outcrop or deepest exploration

2 Ore 50 meters below lowest outerop or deepest exploration.

SUMMARY OF ÁGUAS CLARAS HEMATITE DEPOSITS

Exploration in progress at the time of writing in mid1958 was rapidly increasing the reserves of indicated 
ore. The estimates in this report had by that time been shown to be too low.

The total estimates of the indicated ore in this report for areas 1 through 10 is about $130,000,000$ tons. Inferred ore (50 meters below lowest exposure) totals $89,000,000$ tons.

Rich itabirite, 50-65 percent iron, has not been estimated, but there is probably about $60,000,000$ tons of this material within 50 meters below the lowest outcrop.

\section{FAZENDA CONDE}

A hematite deposit in the southwestern part of the Belo Horizonte quadrangle (N. 1,000, E. 4,500 ) is being developed by Mineracão Mannesmann. (See fig. 32.)

When this area was first mapped (1952), a few places with boulders of hard hematite in the soil, and one artificial exposure of hard hematite were the only indications of ore; the size or value of the unexposed deposit could not be determined. Later exploration revealed a considerable deposit of soft and intermediate ore. This suggests that there may be many other deposits of soft and intermediate hematite ore in the Quadrilátero Ferriffero that give no surface indication of their presence.

The following minimum tonnage estimate is based on data available in early 1958 :

35,000 square meters.

160,000 tons of hematite per meter of depth.

Estimated texture: Dominantly soft and intermediate ore; very little hard lump.

TABLE 13.-Ore estimate, Fazenda Conde, Belo Horizonte quadrangle

\begin{tabular}{c|c|c}
\hline $\begin{array}{c}\text { Indicated } \\
\text { (tons per meter } \\
\text { depth) }\end{array}$ & $\begin{array}{c}\text { Inferred } \\
\text { (tons to 50 meters } \\
\text { depth) }\end{array}$ & Total \\
\hline $\mathbf{1 6 0 , 0 0 0}$ & $8,000,000$ & $8,000,000$ \\
\hline TANQUE
\end{tabular}

A small outcrop of hard hematite occurs in the area known as Tanque at Macacos N. 11,150, E. 1,050.

The grade of the surrounding canga is not high and offers no indication that it might be underlain by highgrade ore. The exposed hematite body is estimated to contain about 1,000 tons of ore per meter depth.

Three short adits were driven southwest of the outcrop. None encountered high-grade hematite even though all three were in rich itabirite containing over 60 percent iron.

\section{BARREIRO OR MUTUCA NO. 1}

The area around Macacos N. 9,700, E. 300 is known as Barreiro or Mutuca no. 1. No high-grade hematite is exposed at the surface, and the canga appears to be of the ordinary type.
An adit 86 meters long penetrated westward from below the east canga scarp. For the first 54 meters it was in canga and limonitized rubble containing 55-62 percent iron and about 0.35 percent phosphorus. From 54 to 72 meters the rock, thought to be rich itabirite, contained about 66 percent iron and about 0.12 percent phosphorus. From 72 to 86 meters the iron content dropped to about 58 percent and the phosphorus went up to 0.23 percent. Because it is not possible to make a tonnage estimate based on the 18 meters of material in the adit that contained more than 60 percent iron, no estimate of reserves has been made for this area. Material containing 55 to 60 percent iron is so common that it is used as road gravel and ballast.

\section{JANGADA}

One of the more spectacular scenic features caused by hard, "blue" hematite ore in the Quadrilátero Ferrífero is the prominence at Ibirité N. 3,900-E. 3,900. (See fig. 33.) It is called Jangada, presumably because the four prominent ridges of hematite that extend eastward from the main peak might be compared to the coconut palm logs used to make jangadas, the sailing rafts used by fishermen of northeastern Brazil.

The deposit was mapped at a scale of $1: 2,000$. Plate 10 shows the relationship of the several ore bodies in the Jangada area and the accompanying index map shows the code that will be used to refer to these ore bodies in the text that follows. Strictly speaking, only " $\mathrm{A}$ " is Jangada; ore bodies " $\mathrm{B}$ " through " $\mathrm{E}$ " may be connected to Jangada beneath the cover of boulders, but "F," "G," and " $H$ " are probably parts of a separate deposit.

Calculation of reserves.--It was assumed that the Jangada ore deposit is an inclined irregularly elongate body, the attitude and shape of which is defined by the outline of the outcrop and the lineation of the ore. In calculating the reserves the topographic contours on the eastern slope were continued westward along the mapped edge of the ore body as approximate contours and thus closed around the assumed prismatic ore body. The area of hematite enclosed by each 10 -meter contour then was measured with a polar planimeter.

The average of the areas within each consecutive pair of 10-meter contours was taken as the horizontal area of the "slice"; this, multiplied by 10 , gave the volume of the "slice" in cubic meters. This was done for every adjacent pair of 10-meter contours down to the lowest contour that followed any part of the hematite outcrop.

The volume thus obtained represents hematite above a horizontal plane passed through the lowest exposures. This volume multiplied by a specific gravity of 4.5 results in a reserve estimate of approximately 5 million tons. Below the lowest outcrop (at contour 1,280), 


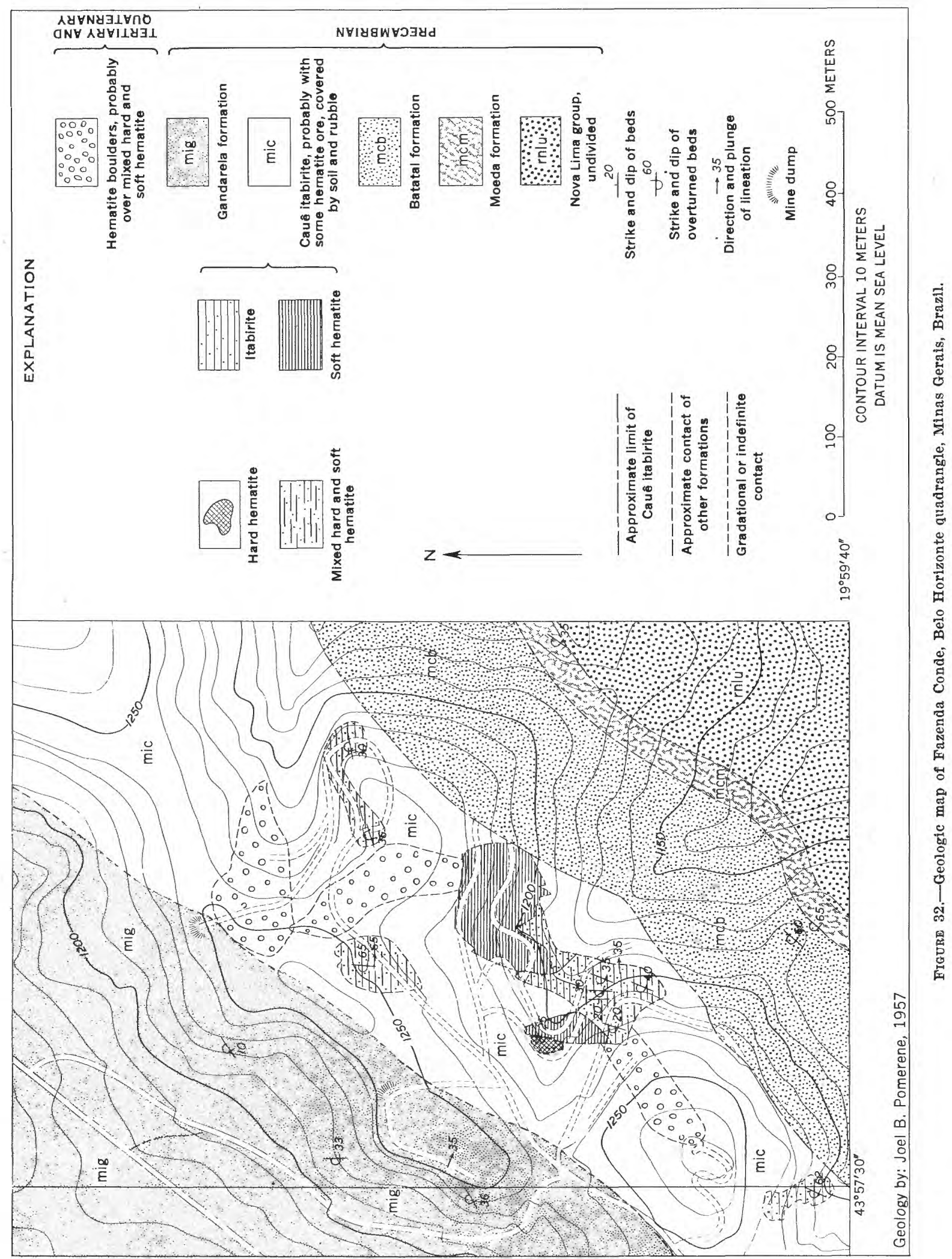




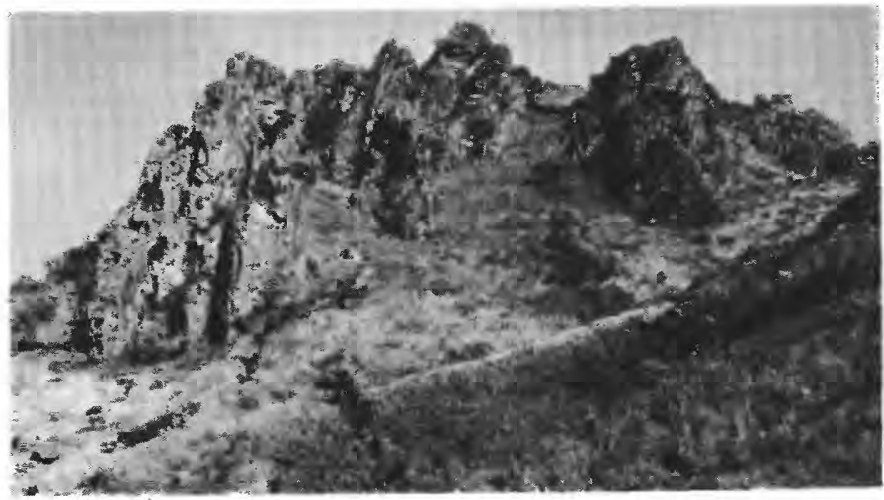

Figrie 33.- Jangada. All the rock visible in this photograph contains over 66 percent iron.

about 50,000 tons per meter can be estimated, or another 2.5 million tons to 50 meters below the outcrop. This is an arbitrary assumption but probably is the most reasonable one considering the lack of subsurface information.

Reserves of ore in areas other than "A", "I", and "J", were calculated by multiplying the area by the assumed specific gravity to give tons per meter of depth. Two deposits of rubble ore, areas " $\mathrm{I}$ " and " $\mathrm{J}$ ", cannot be projected to any great depth. The other areas, which are bedrock ore, have been tentatively projected to a depth of 50 meters. Some of the bodies may not go to this depth but statistically this depth of projection should be reasonable, given the size of outcrops and the nature of ore bodies of this type as known elsewhere in the Quadrilátero Ferrífero.

Large areas of soil with many boulders, cobbles, and pebbles of hematite occur on the slopes away from Jangada and are shown on the map. Deposits of canga rica cover smaller areas than do the boulders, cobbles, and pebbles, but nevertheless are prominent.

TABLE 14.-Ore estimate of Jangada area, Ibirité quadrangle [All estimates rounded off to two significant figures]

\begin{tabular}{|c|c|c|c|c|}
\hline Area & $\begin{array}{l}\text { Square } \\
\text { meters }\end{array}$ & $\begin{array}{l}\text { Indicated ore } \\
\text { (tons per } \\
\text { meter of } \\
\text { depth) }\end{array}$ & $\begin{array}{c}\text { Inferred ore } \\
\text { (tons to } 50 \\
\text { meters below } \\
\text { outcrop) }\end{array}$ & Total \\
\hline $\begin{array}{l}\text { A (Jangada) } \\
\text { C } \\
\text { D } \\
\text { F } \\
\text { G } \\
\text { I Boulders } \\
\text { J Boulders. }\end{array}$ & $\begin{array}{r}180 \\
640 \\
2,200 \\
1,400 \\
5,400 \\
700 \\
7,500 \\
9,500 \\
7,900\end{array}$ & $\begin{array}{r}15,000,000 \\
800 \\
2,900 \\
9,900 \\
6,300 \\
24,000 \\
3,200 \\
34,000 \\
\end{array}$ & $\begin{array}{r}2,500,000 \\
40,000 \\
140,000 \\
500,000 \\
320,000 \\
1,000,000 \\
160,000 \\
1,700,000 \\
\end{array}$ & $\begin{array}{r}7,500,000 \\
40,000 \\
140,000 \\
500,000 \\
320,000 \\
1,000,000 \\
160,000 \\
1,700,000 \\
\end{array}$ \\
\hline Total. & - - - & $5,081,100$ & $6,360,000$ & $11,360,000$ \\
\hline Rounded total & - & $5,100,000$ & $6,400,000$ & $11,000,000$ \\
\hline
\end{tabular}

1 Tons above lowest outcrop.

2 Tons 50 meters below lowest outcrop.
The structure in the Jangada area can only be inferred, and on very scanty evidence. The ore in the four major eastward extensions of Jangada, or the " $\mathrm{A}$ " ore body, may have developed in tight isoclinal, steeply eastward-plunging folds. The only evidence suggesting this is found at the eastern tip of the southernmost extension. At this point, bedding in the hematite seems to curve around the tip of the extension. The other three major extensions may be of similar structure, but if so, erosion has removed the extreme tips where the curvature of bedding would be visible in isoclinal folds. If the ore has developed on isoclinal folds in the " $A$ " ore body, it is reasonable to consider that ore bodies B, C, D, and $\mathrm{E}$ may also be in isoclinal folds and possibly are continuous with " $\mathrm{A}$ " underground. Exploration adits being driven at present (mid-1958) and planned diamond-drill holes will probably prove or disprove this hypothesis. Ore bodies "F", "G", and "H" cannot be correlated directly with the others at the present time. But if isoclinal folding is proved to be the structural control of ore bodies " $\mathrm{A}$ " through " $\mathrm{E}$ " then it would be reasonable to assume that ore bodies " $F$ " through " $\mathrm{H}$ " are related to a similar structure.

\section{SAMAMBAIA}

The Samambaia hematite deposit (see pl. 11) in the vicinity of Ibirite N. 3,200, E. 2,100 occurs on and beneath a more or less even surface that slopes about $20^{\circ}$ SE. Most of the slope is covered with canga, canga rica, and soil containing many fragments of hard hematite ore in pebble to boulder size. A few outcrops of hematite with ill-defined boundaries occur on the canga slope. Outcrops of mixed hard and soft hematite ore grade imperceptibly into rich canga. Many of the individual areas listed below may be the harder, exposed parts of large, dominantly soft, hematite bodies. The "structure of ore" described below for each area is estimated from surface exposures and may be different at depth.

The western scarp at the very edge of the mapped area on plate 11 , with a slope of $60^{\circ}$ to $70^{\circ}$, provides almost ideal access for deep exploration by adits. An adit driven east to northeast from far down the scarp would be approximately along the strike of the Cauê itabirite, necessitating crosscuts to explore the section, but the difficulty and expense of crosscuts might be compensated by the ease of exploration to depth.

The numerical designations of the areas described below correspond to the reference numbers on the largescale map of Samambaia. 
AREA 1

230 square meters.

1,000 tons of hematite per meter of depth.

Structure of ore: Platy hematite, about 60 percent soft.

Observations: Exposure is actually 2 to 3 meters of canga scarp, but fractured broken fragments of harder layers are parts of a slumped outcrop. Surface apparently is ordinary canga, so the southern extent of ore body can only be delineated by subsurface exploration.

AREA 2

620 square meters.

2,800 tons of hematite per meter of depth.

Structure of ore: Platy hematite with zones of soft and layers of hard hematite.

Observations: Rich canga to the west probably overlies soft hematite with platy layers. A test pit at the western extremity of the area revealed platy hematite or leached itabirite. The area of rich canga is about 3,100 square meters; about 12,000 tons per meter of depth.

AREA 3

Surficially enriched itabirite outcrops in ordinary canga. A few beds of hard hematite, 10 to 20 centimeters thick, occur in the itabirite.

AREA 4

350 square meters.

1,600 tons of hematite per meter of depth.

Structure of ore: About half soft hematite and half fragments over one inch.

AREA 5

3,000 square meters.

14,000 tons of hematite per meter of depth.

Structure of ore: Dominantly soft hematite with hard hematite layers 1 to 3 centimeters thick. Zones of thin platy hematite probably occur.

AREA 6

650 square meters.

2,900 tons of hematite per meter of depth.

Structure of ore: Platy and soft hematite.

AREA 7

400 square meters.

1,800 tons of hematite per meter of depth.

Structure of ore: Platy and soft hematite with a few 10-centimeter bands of hard hematite.

Observations: May be part of same hematite body as 5 and 6. Intervening area is rich canga with platy fragments of ore which may overlie soft, somewhat platy hematite.
1,100 square meters.

5,000 tons of hematite per meter of depth.

Structure of ore: Platy to soft hematite.

AREA 9

800 square meters.

3,600 tons of hematite per meter of depth.

Structure of ore: Platy and soft hematite.

Observations: It is quite probable that areas 5 through 9 are parts of one ore body. If this is the case that body would cover an area of about 10,370 square meters and contain about 46,500 tons per meter of depth.

1,600 square meters.

AREA 10

7,200 tons of hematite per meter of depth.

Structure of ore: Mostly soft hematite, with minor thin layers of hard hematite.

AREA 11

340 square meters.

1,500 tons of hematite per meter of depth.

Structure of ore: Hard hematite.

Observations: Hematite is highly contorted; many

blocks broken from outcrop. Area to the south is scattered with boulders of hard hematite derived from this outcrop. They may overlie mixed hard and soft ore.

It is possible that areas 4 through 11 are parts of one large hematite deposit, much of which is overlain by canga rica. If this is the case, the deposit would contain about 120,000 tons of hematite per meter of depth.

Exploration of this area might prove'a large tonnage of hematite; an adit started on the western scarp 50 to 100 meters below area 11, and driven 200 to 300 meters east-northeast should prove or disprove the continuity of hematite areas 4 through 11.

340 square meters.

AREA 12

1,500 tons of hematite per meter of depth.

Structure of ore: Hard hematite with minor zones of platy and soft hematite.

Observations: The ore body probably extends to the east as mixed hard and soft hematite. This is indicated by a band of high-grade canga overlain by scattered boulders of hard hematite ore. As the extension is not directly downhill from the outcrop of hard hematite ore, the boulders could not have broken from the outcrop and rolled to their present position by gravity.

AREA 13

260 square meters.

1,200 tons of hematite per meter of depth. 
Structure of ore: Actually canga rica, probably overlying mixed hard and soft hematite.

AREA 14

160 square meters.

700 tons of hematite per meter of depth.

Structure of ore: Dominantly hard hematite.

Observations: Hematite is cut by numerous quartz veins which would lower the "mine run" grade somewhat. Introduction of quartz probably followed fracturing associated with post-ore faulting.

AREA 15

390 square meters.

1,800 tons of hematite per meter of depth.

Structure of ore: Mixed hard and soft hematiteabout 40 percent hard hematite.

Observations: Surrounding area is rich canga with no indication of itabirite. This canga probably represents an extension of dominantly soft and platy ore from area 15. Area 15 plus its possible extension covers 1,400 square meters that indicate 6,500 tons of hematite per meter of depth.

AREA 16

Small outcrop of highly contorted, hard itabirite. The large area north-northeast of this outcrop is covered by canga interpreted as overlying itabirite.

1,400 square meters.

AREA 17

6,300 tons of hematite per meter of depth.

Structure of ore: Mixed hard and soft hematite with about 40 percent hard hematite.

3,400 square meters.

AREA 18

15,000 tons hematite per meter of depth.

Structure of ore: Massive hard hematite and contorted hard hematite with minor zones of mixed hard and soft hematite.

Observations: Area to south of this is covered by canga rica littered with cobbles and boulders of hard hematite.

1,800 square meters.

AREA 19

8,100 tons of hematite per meter of depth.

Structure of ore: About 50 percent lump hematite and 50 percent soft and platy hematite.

Observations: As with all the hematite areas in Samambaia the southern, downhill boundary is indefinite. Broken outcrop grades into canga rica and high-grade canga.

AREA 20

600 square meters.

2,700 tons of hematite per meter of depth.
Structure of ore: Many small outcrops of hard hematite in a field of canga rica suggest bands of hard hematite in a body of soft and platy hematite.

Observations: May be part of the same hematite body as in areas 17, 18, and 19.

The total of areas $17,18,19$, and 20 , plus associated high-grade canga is about 18,000 square meters. If this is all underlain by hematite, it represents a deposit containing about 80,000 tons of hematite per meter of depth.

AREA 21

This is soil and iron formation detritus containing many pebbles, cobbles, and boulders of hard hematite. In places the hematite cobbles are almost in contact with one another with soil filling the interstices; in other places only scattered hematite boulders occur in the soil. This material was being mined with pick and shovel in mid-1958; screening separates the hematite and the soil.

The area of hematite boulders in soil extends downhill and southward for several kilometers out over the granite. Boulders have been mined and shipped from the southern end of this area (Ibirité N. 600, E. 2,300) for several years.

The slope of the deposit is quite even from Samambaia to the boulder mine. The deposit is probably a remnant of a Tertiary (?) outwash plain or pediment.

If areas 5 through 9 , plus surrounding rich canga, represent one large body, then the totals for Samambaia (table 15) would be 94,000 tons per meter and $4,700,000$ tons to 50 meters depth. If areas 4 through 11 , plus surrounding rich canga, represent one ore body, the corresponding figures would be 160,000 and $7,900,000$.

TABLE 15.-Ore estimate of Samambaia, Ibirité quadrangle [All estimates rounded off to two significant figures]

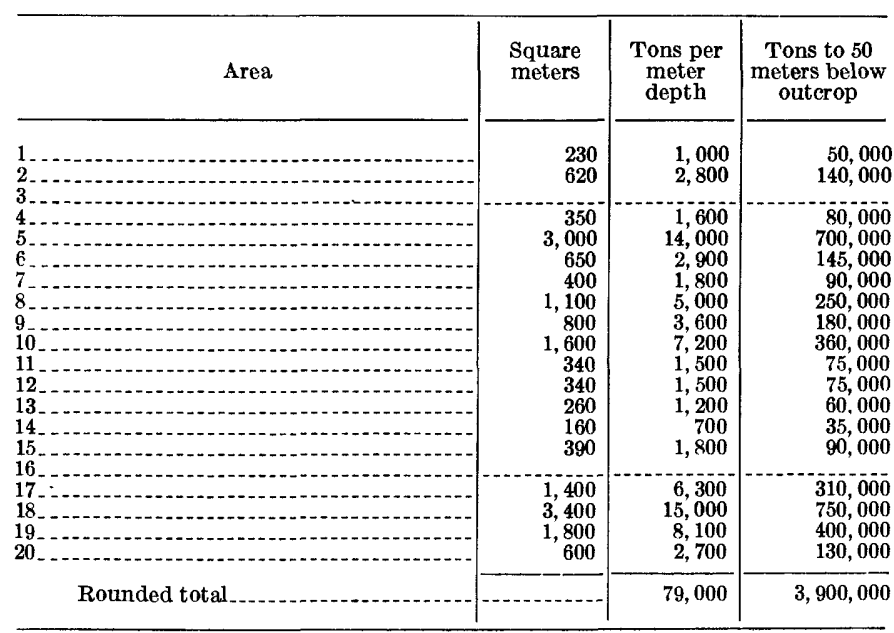


Samambaia is a promising area; a relatively small amount of exploration would probably reveal several ore bodies of moderate size. The total estimated tonnage of Areas $1-20$ is about 79,000 tons per meter of depth on an engineering basis (visible ore only). On a geologic basis, it is probable that the tonnage of highgrade hematite ore in the Samambaia area will prove, on exploration, to be several times this figure. A number of the soft ore deposits, treated individually above, are probably continuous beneath the canga, forming one or more larger bodies.
A low hill extends above the Tertiary and Quaternary alluvium at Macacos N. 8,700, E. 2,300, in the area flnown as Capão Xavier (see figs. 34 and 35).

From the appearance of canga rica on the surface it is likely that the entire hill consists of high-grade hematite ore, mostly platy and soft. The only underground explorations up to early 1958 were several shallow pits and a 2-meter adit. All of these were either in canga rica or high-grade intermediate to hard ore.

The volume of the hill above the 1,360-meter contour (the general level of the Tertiary and Quaternary alluvium) is estimated to be $4,500,000$ cubic meters. This

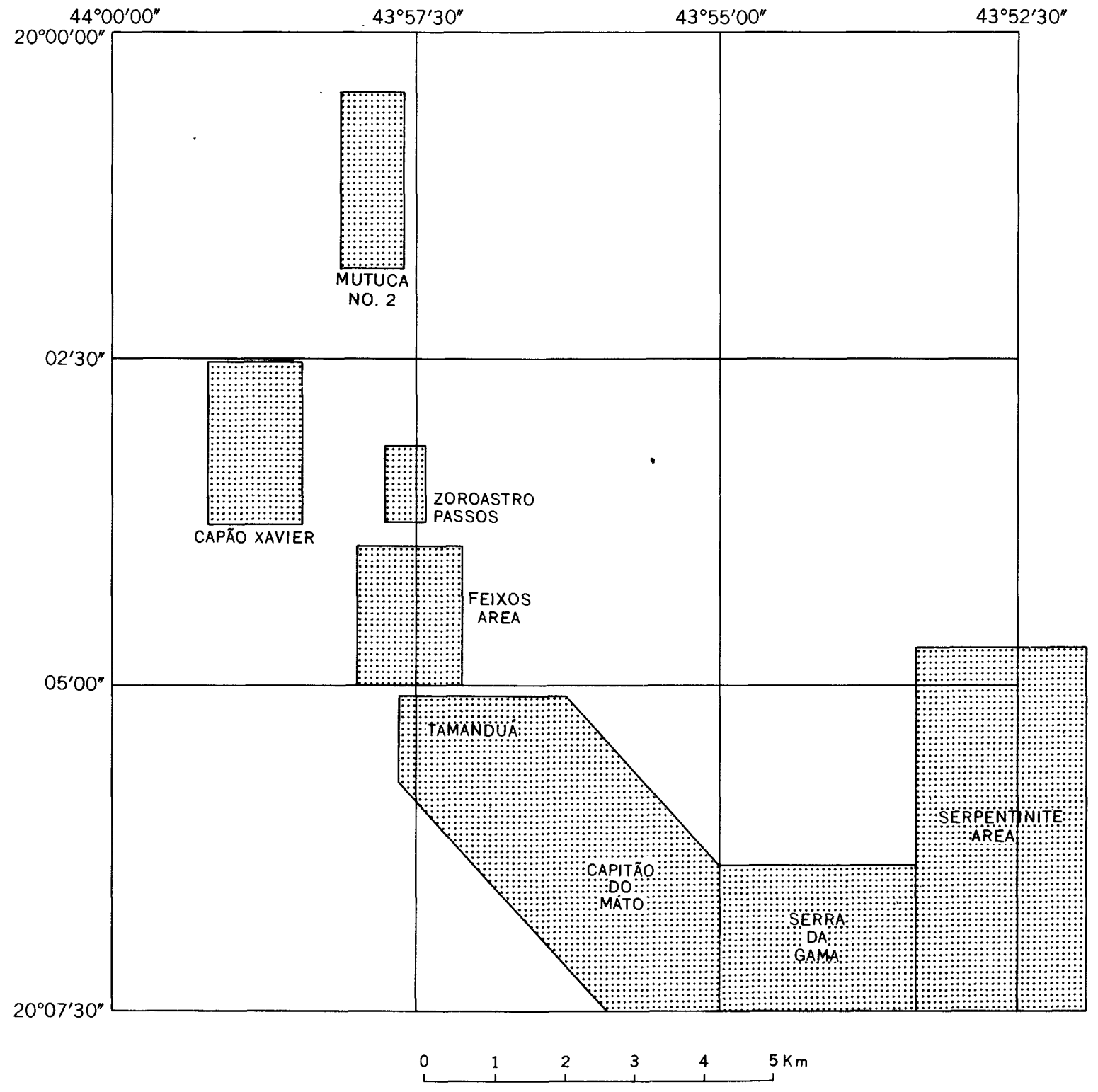

Frgore 34.--Index map of Macacos quadrangle showing locations of detailed maps. 


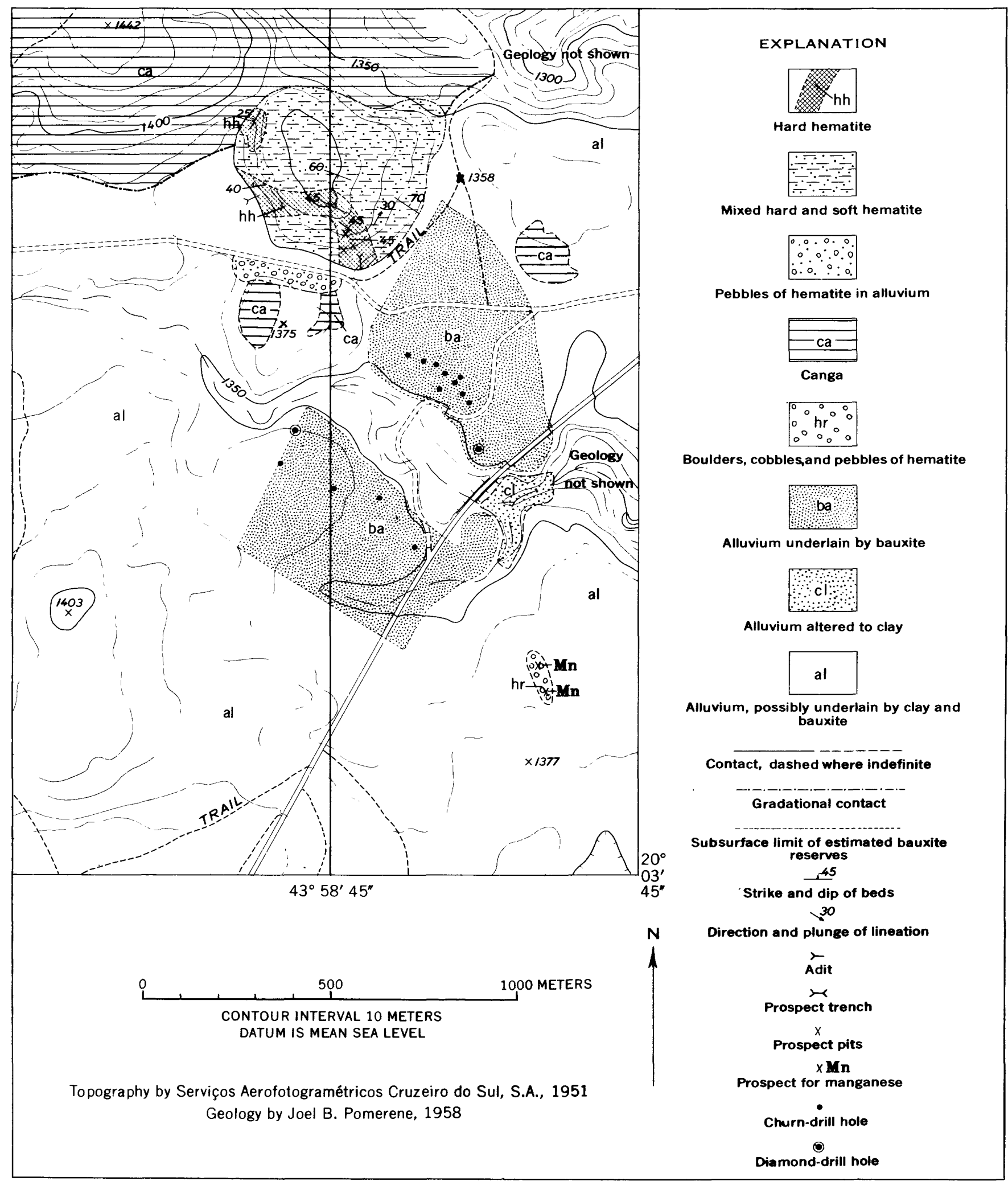

Figure 35.-Geologic map of Capão Xavier and vicinity, Macacos quadrangle, Minas Gerais, Brazil. 
volume times the factor of 4.5 results in an indicated reserve of about $20,000,000$ tons of hematite. If the ore extends to depth, the deposit will contain at least an additional $39,000,000$ tons of hematite to 50 meters below the 1,360-meter contour.

\begin{tabular}{|c|c|c|}
\hline $\begin{array}{c}\text { Indicated ore } \\
\text { (tons above } \\
\text { lowest outcrop) }\end{array}$ & $\begin{array}{l}\text { Inferred ore } \\
\text { (tons } 50 \text { meters } \\
\text { below lowest } \\
\text { outcrop) }\end{array}$ & Total \\
\hline $20,000,000$ & $39,000,000$ & $59,000,000$ \\
\hline
\end{tabular}

MUTUCA NO. 2 DEPOSIT

The hematite deposits in the vicinity of Macacos N. 11,800, E. 3,700 are known collectively as the Mutuca no. 2 deposit. As shown on the detailed map (fig. 36) the outcrop consists of several small exposures of hard ore and large areas of canga rica and hematite boulders.

The ore estimates in table 17 are based on 4 small outcrops of hard ore in the northern part of the deposit, 2 outcrops in the central part of the area, 3 small outcrops in the southern part of the deposit, and 2 canga fields. Soft and mixed hard and soft ore probably underlie part of the areas covered by canga rica and by boulders of hard ore.

The thickness of the canga rica is not likely to be over 5 meters, and may be less than 1 meter in some places.

The northern part of Mutuca no. 2 is controlled by Mineração Mannesmann. At present (1958) the company is mining only loose hematite boulders that occur mixed with soil on the northwest, north, and northeast slopes of the main ridge.

TABLE 17.-Ore estimate of Mutuca No. 2, Macacos quadrangle [Estimates rounded off to two signiflcant flgures]

\begin{tabular}{|c|c|c|c|}
\hline Area & $\begin{array}{l}\text { Square } \\
\text { meters }\end{array}$ & $\begin{array}{l}\text { Tons per } \\
\text { meter } \\
\text { depth }\end{array}$ & $\begin{array}{l}\text { Tons to } 10 \\
\text { meters below } \\
\text { outcrop }\end{array}$ \\
\hline $\begin{array}{l}\text { Northern outcrops } \\
\text { Central outcrops } \\
\text { Southern outcrops. }\end{array}$ & $\begin{array}{r}6,500 \\
7,700 \\
2,800\end{array}$ & $\begin{array}{l}29,000 \\
35,000 \\
13,000 \\
77,000\end{array}$ & $\begin{array}{l}290,000 \\
350,000 \\
130,000 \\
770,000\end{array}$ \\
\hline $\begin{array}{l}\text { Northern canga rica } \\
\text { Southern canga rica }\end{array}$ & $\begin{array}{r}86,000 \\
200,000\end{array}$ & $\begin{array}{l}340,000 \\
800,000\end{array}$ & (n) \\
\hline
\end{tabular}

None of the ore bodies in this deposit can safely be projected to depth because the deposit occurs on the upper plate of a major thrust-tear fault. The fault plane probably dips about $80^{\circ} \mathrm{E}$. to SE., on the basis of exploration done after this paper was written (see the cross section in fig. 36).

\section{ZOROASTRO PASSOS}

A medium-sized deposit of hematite occurs as Maca$\cos$ N. 7,500, E. 4,200 in the area known as Zoroastro Passos. (See fig. 37.) Except for a few very small lenses of hard hematite the deposit consists almost entirely of mixed hard and soft ore. A zone of loose cobbles and boulders of hard hematite occurs in soil at the north end of the deposit.

Only canga rica is exposed south of the creek (see map) but it probably overlies mixed hard and soft hematite ore. No underground exploration of any kind has been done on this deposit, so the reserve estimate is based entirely on surface mapping.

Two different methods were used to calculate the volume of ore in this deposit. In the first, the area of ore in the cross section accompanying figure 37 was measured and multiplied by the length of the outcrop. In the second method, the area of ore shown on the map was measured and multiplied by the distance between highest and lowest parts of the outcrop. A volume of about 2.2 million cubic meters was indicated by both methods, which corresponds to a reserve of about 10 million tons.

\section{FEIXOS AREA}

Two hematite deposits occur in the part of the Macacos quadrangle known as Feixos. (See fig. 38.)

The northern of these occurs near N. 6,200, E. 4,400, Macacos quadrangle. Hard ore crops out on two sides of the hill. The combined area of the two outcrops is about 5,100 square meters, representing about 23,000 tons of hematite per meter of depth.

The top of the hill is covered by canga rica that is probably underlain by a body of mixed hard and soft ore (pl. 2). The total area is about 35,000 square meters. The ore estimate for this deposit is given in table 18.

TABLE 18.-Ore estimate of the Feixos area, Macacos quadrangle [Estimates rounded off to two significant flgures]

\begin{tabular}{c|r|r|r}
\hline Area & $\begin{array}{r}\text { Square } \\
\text { meters }\end{array}$ & $\begin{array}{r}\text { Tons per } \\
\text { meter } \\
\text { depth }\end{array}$ & $\begin{array}{r}\text { Tons to 50 } \\
\text { meters below } \\
\text { outcrop }\end{array}$ \\
\hline $\begin{array}{r}\text { Northern two outcrops plus canga rica area } \\
\text { Southern outcrop... }\end{array}$ & $\begin{array}{r}35,000 \\
3,200\end{array}$ & $\begin{array}{r}160,000 \\
14,000\end{array}$ & $\begin{array}{r}8,000,000 \\
700,000\end{array}$ \\
\hline
\end{tabular}

The southern hematite ore body is at Macacos $\mathrm{N}$. 4,700 , E. 4,000 , where hard ore crops out over an area of 3,200 square meters (see table 18). The canga north of the outcrop appears to be of the ordinary type, and so a northward extension of this deposit seems unlikely.

\section{TAMANDUÁ-CAPITÃo DO MATO-SERRA DA GAMA}

Many outcrops of high-grade hematite ore occur along the eastern limb of the Moeda syncline in the southeastern part of the Macacos quadrangle. The mapped width of the Cauê itabirite in this zone is about 1,500 meters, or approximately five times the average true thickness of the formation. This great width is attributed to tight isoclinal folding which repeats the 


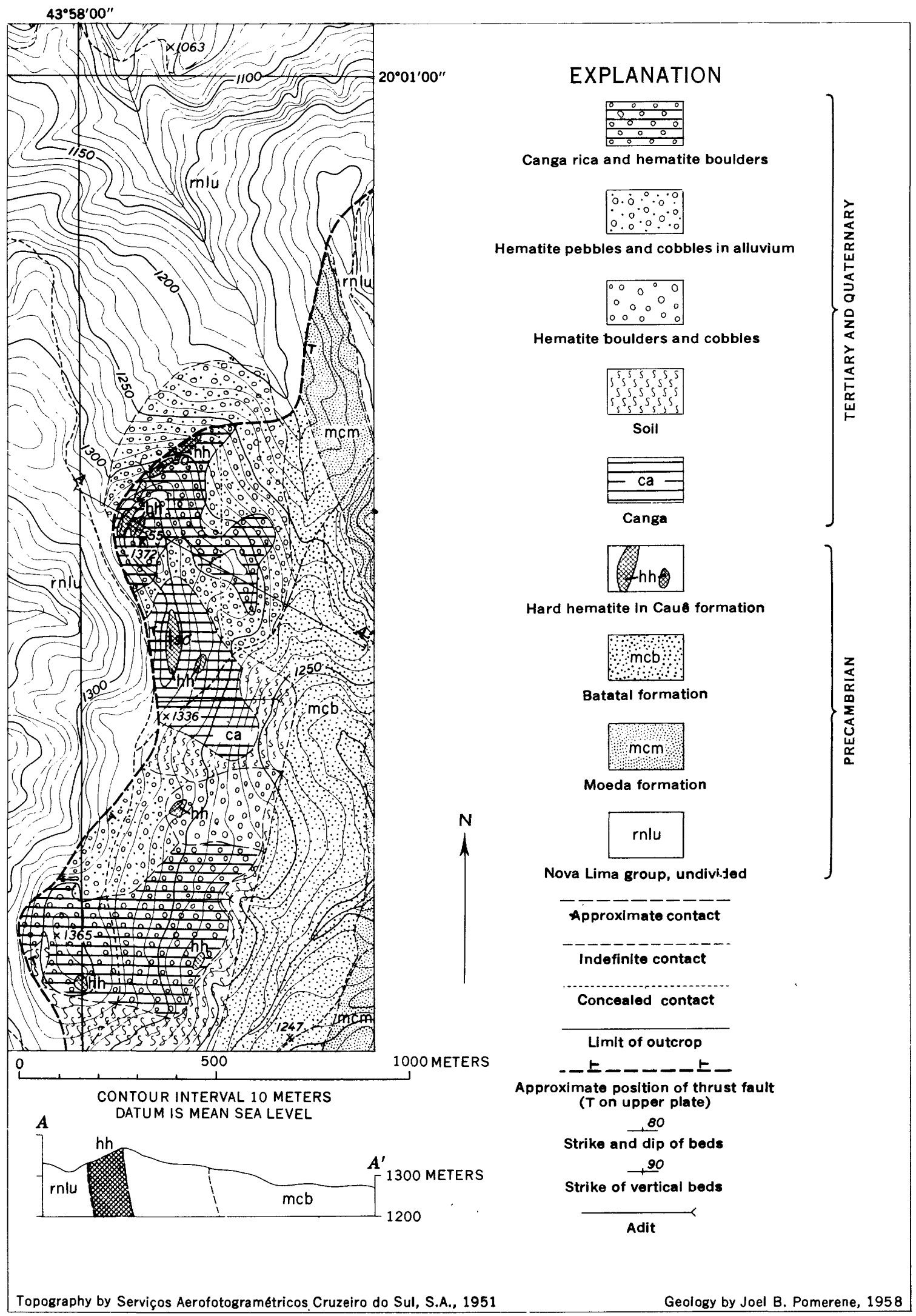

Figure 36.-Geologic map and section of the Mutuca no. 2 deposit, Macacos quadrangle, Minas Gerais, Brazll. 


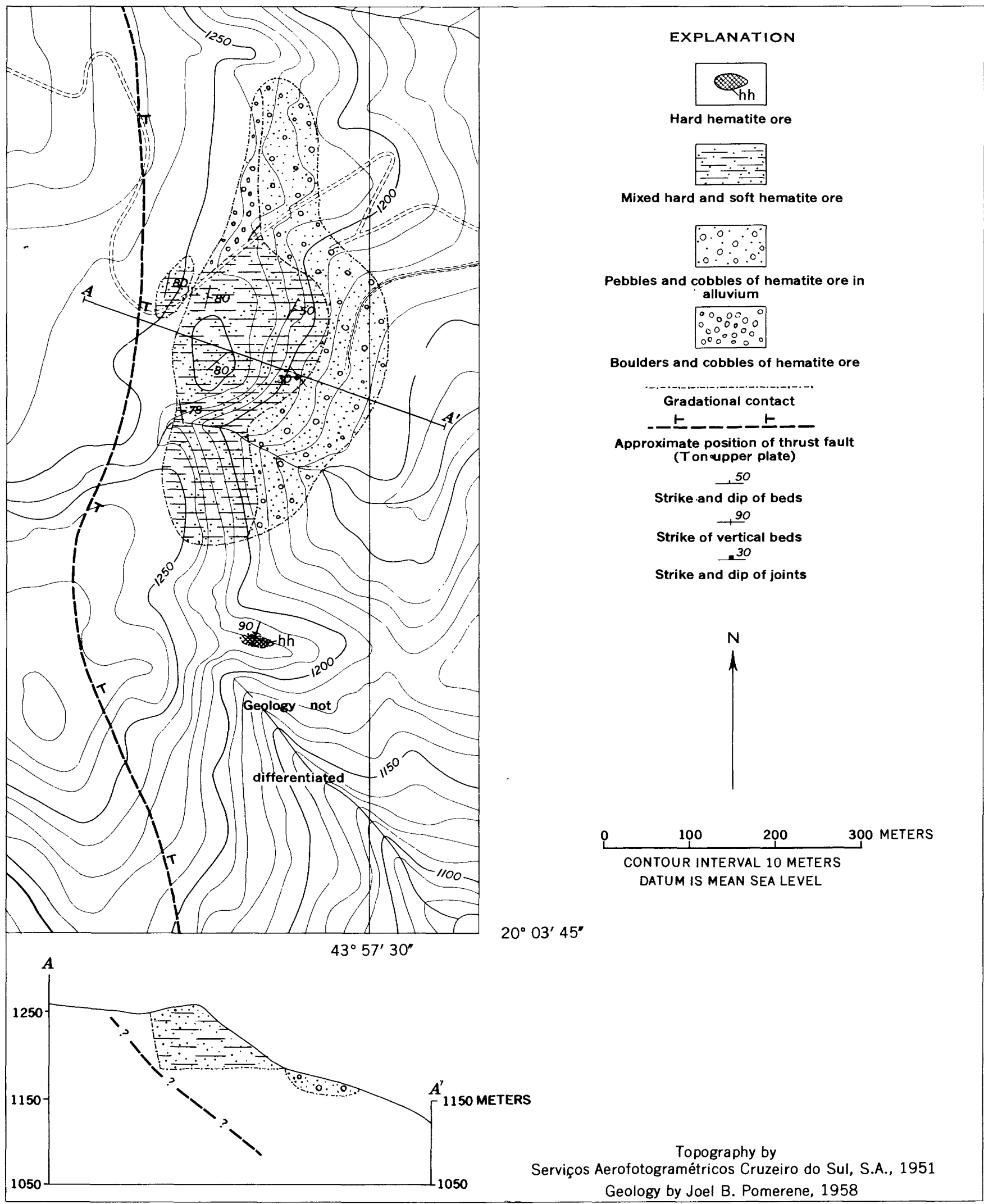

Frgure 37.-Geologic map and section of Zoroastro Passos, Macacos quadrangle, Minas Gerais, Brazil. 


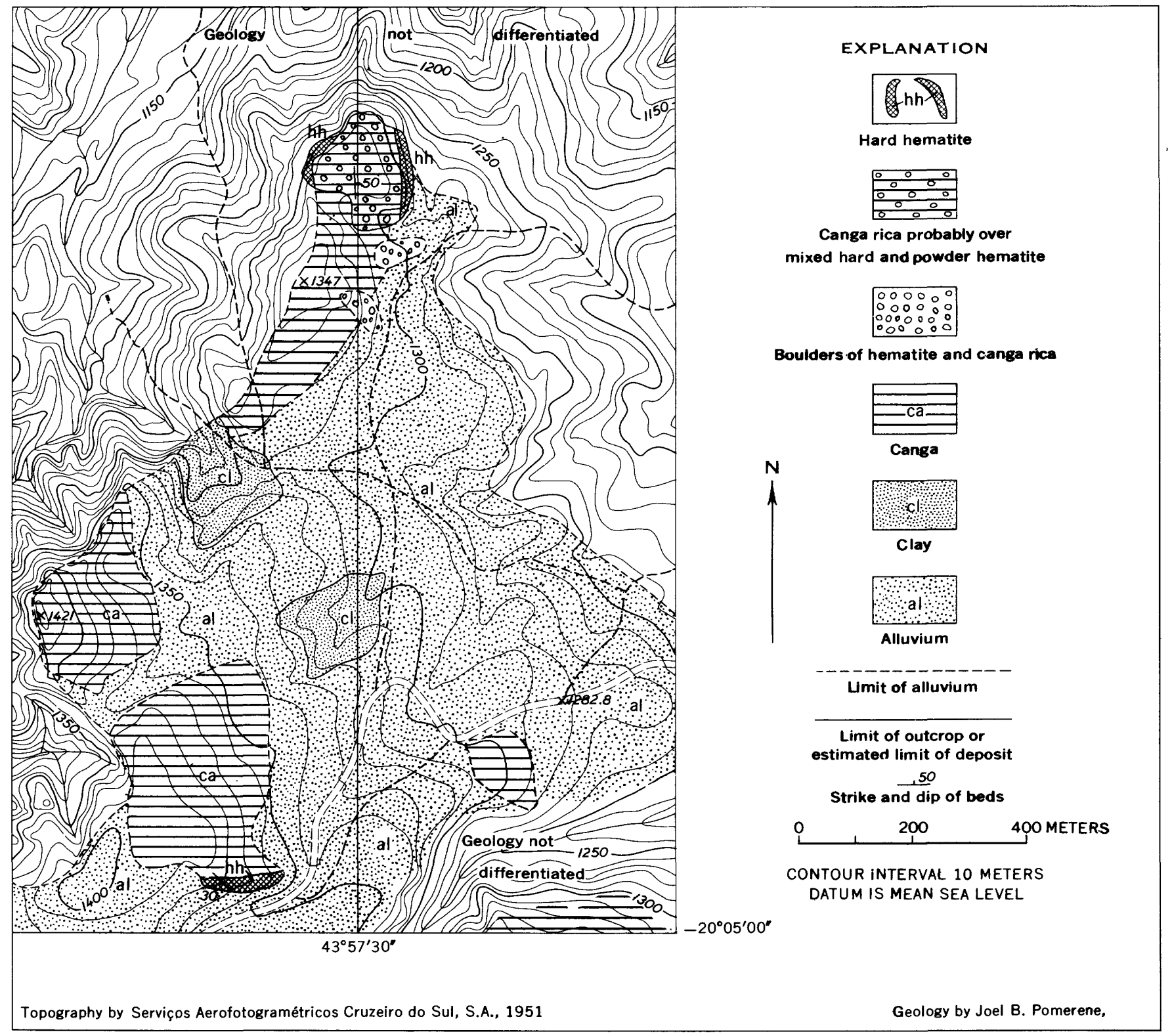

Figure 38.-Geologic map of the Feixos area, Macacos quadrangle, Minas Gerais, Brazil.

formation five times, as shown on structure cross-section $G-G^{\prime}$.

Probably some squeezed and sheared beds of the Batatal and Gandarela formations are infolded into the Cauê itabirite. Although neither the yonger nor the older formation crops out at the surface, zones of sheared phyllite and schist have been encountered in underground exploration. Many deeply weathered dikes of unknown original composition cut the itabirite and the high-grade hematite ores.

As shown in detail on plate 12 , the northern part of the area is known as Tamandua, the middle part as Capitão do Mato, and the southeastern part as the Serra da Gama.
Areas of hematite ore, designated and numbered on the map, in general from northwest to southeast, correspond to the numerical designations of the areas described below.

Some of these areas of hematite may be high parts of a large mass of ore for the most part covered by alluvi$\mathrm{um}$. Others may be small isolated lenses with very little extension to depth; still others may extend to considerable depth. Dikes and infolded schist and phyllite may limit some of the ore bodies, both laterally and vertically.

Of the 97 areas of hematite ore in the TamanduáCapitão do Mato-Serra da Gama region, only one (area 56) has been explored to a depth greater than 5 meters. 
AREA 1

70,000 square meters.

310,000 tons of hematite per meter of depth.

Structure of ore: $25-50$ percent hard hematite, 50-75 percent soft ore in the southwest quarter of the area. Other parts of area, probably 20 percent of plus onehalf inch, 80 percent of minus one-half inch.

Observations: This is a field estimate based on the appearance of the canga surface.

AREA 2

24,000 square meters.

110,000 tons of hematite per meter of depth.

Structure of ore: Mostly soft hematite with thin beds and lenses of hard hematite.

Observations: Laminated canga almost surely representing mixed soft and platy hematite, with beds and lenses of thin-bedded, hard, dense hematite 1 to 2 meters thick.

AREA 3

1,300 square meters.

5,800 tons of hematite per meter of depth.

Structure of ore: Alternating laminae of hard and soft hematite.

Observations: Surface consists of angular, thin, small plates of hematite cemented by limonite in parallel or subparallel orientation.

AREA 4

5,200 square meters.

23,000 tons hematite per meter of depth.

Structure of ore: Very thin bedded, schistose, possibly with much soft hematite.

Observations: Surface consists of oriented blades of schistose ore, about razor-blade size, cemented by limonite.

AREA 5

1,600 square meters.

7,200 tons hematite per meter of depth.

Structure of ore: Probably more than 75 percent hard hematite, 25 percent soft.

Observations: Canga to the north is quite rich, and may overlie soft and mixed hard and soft ore.

AREA 6

7,100 square meters.

32,000 tons hematite per meter of depth.

Structure of ore: Probably 50-75 percent small lump hematite, the remainder soft hematite.

Observations: Outcrop is mostly breccia of hematite ore with fragments about 5 by 30 by 30 millimeters. Many fragments of hard ore as large as 10 centimeters.

AREA 7

13,000 square meters.

58,000 tons of hematite per meter of depth.
Structure of ore: Probably about 50 percent hard hematite, 50 percent mixed soft and platy hematite.

Observations : Many large blocks of hard ore on surface. Area between them is cemented platy and granular ore with many cobbles of hard ore.

AREA 8

7,800 square meters.

35,000 tons of hematite per meter of depth.

Structure of ore: Probably 75 percent hard hematite, 25 percent soft.

Observations: Many large blocks of hard ore as much as 1 meter long. Outcrop is of massive, compact hematite, but weathering has etched surfaces which show its original thin-bedded character.

AREA 9

6,500 square meters.

29,000 tons of hematite per meter of depth.

Structure of ore: Probably about 50 percent small to medium-lump hematite ( $1 / 2$ to $2 \mathrm{in}$.) and 50 percent soft hematite.

Observations: Outcrop is contorted thin-bedded to schistose hematite ore. Red soil in topographically lower area to east is probably over a dike.

AREA 10

3,900 square meters of canga rica. May be broken and cemented outcrop of hard hematite ore.

AREA 11

48,000 square meters.

220,000 tons of hematite per meter of depth.

Structure of ore: Probably 25-50 percent hard hematite, 50-75 percent soft hematite.

Observations: The ore on the outcrop is very dense, apparently very fine grained, and somewhat schistose.

AREA 12

10,000 square meters of canga rica. It may be overlying mixed hard and soft hematite ore. No estimate is offered.

AREA 13

9,700 square meters of scattered boulders of hematite ore, 10-50 centimeters in diameter. They may overlie an ore body consisting of layers and lenses of hard hematite in a matrix of soft hematite, but lacking more evidence, no tonnage estimate can be offered.

AREA 14

7,700 square meters.

35,000 tons of hematite per meter of depth.

Structure of ore: Probably 50 percent hard platy hematite of $1 / 2$-inch to 2 -inch size, 50 percent soft hematite. 
Observations: Area 14 contains three areas of outcrop. The interval between outcrops and possibly a large part of the canga rica to the west may well be underlain by soft ore with some lenses of hard ore. These areas are not included in the estimate.

\section{AREA 15}

A few large masses of hard hematite ore which may be huge boulders. or slumped and shifted outcrop. Strikes and dips are erratic. Only a few hundred tons in sight.

AREA 16

Similar to area 15 but smaller. Probably there are a few lenses of hard ore in the areas 15 and 16, but available exposures allow no estimate of tonnage.

AREA 17

23,000 square meters of cobbles and boulders of hard hematite ore sparsely distributed in soil. Evidence is insufficient for toinnage estimate.

AREA 18

29,000 square meters of cobbles and boulders of hard hematite ore. Probably 50 percent plus 1 inch; layer probably 2 meters thick. Rest is soil, soft hematite, and clay.

AREA 19

3,200 square meters.

14,000 tons of hematite per meter of depth.

Structure of ore: Probably 75-100 percent hard hematite.

Observations : Hematite ore is in a small lens; hard pink itabirite is exposed to the west.

AREA 20

2,600 square meters.

12,000 tons hematite per meter of depth.

Structure of ore: Probably 50 percent hard hematite, 50 percent soft hematite, but grading into dominantly soft hematite to east and south.

1,900 square meters.

8,500 tons hematite per meter of depth.

Structure of ore : Less than 25 percent small lump; dominantly soft hematite.

Observations: Gradational into area 20 and into lens of itabirite to west.

AREA 22

2,300 square meters.

10,000 tons hematite per meter of depth.

Structure of ore: Dominantly soft hematite, probably with itabirite lenses.
AREA 23

1,200 square meters.

5,400 tons hematite per meter of depth.

Structure of ore: Schistose hard hematite in place.

Observations : Schistose material, although classified as hard ore in outcrop, will probably break up into 75 percent soft during mining and shipping.

AREA 24

1,200 square meters.

5,400 tons of hematite per meter of depth.

Structure of ore: Mixed small lump and soft hematite.

13,000 square meters.

58,000 tons hematite per meter of depth.

Structure of ore: Probably mostly soft hematite with less than 25 percent small lump. Lenses of itabirite may be present.

AREA 26

14,000 square meters.

63,000 tons hematite per meter of depth.

Structure of ore : About 50 percent hard lump hematite, 50 percent soft hematite.

AREA 27

26,000 square meters of rich itabirite, possibly containing about 60 percent iron.

\section{AREA 28}

3,900 square meters of hematite cobbles mixed with soil. Visible thickness of layer of cobbles is 20 to 30 centimeters.

AREA $\quad 29$

1,900 square meters.

6,000 tons hematite per meter of depth.

Structure of ore: About 75 percent hard hematite, 25 percent soft hematite.

Observations: Ore has been sheared, broken, and recemented to form a pseudocanga rica. Despite shearing, hematite is not schistose.

AREA $: 0$

6,400 square meters.

29,000 tons hematite per meter of depth.

Structure of ore: Less than 40 percent hard hematite, the remainder probably soft hematite.

AREA $: 31$

22,000 square meters thinly covered by hematite cobbles probably overlying rich ( 60 percent) itabirite.

AREA 82

16,000 square meters of hard hematite cobbles mixed with soil. Depth unknown but probably only 1 to 2 meters.

AREA 33

14,000 square meters of canga rica probably overlying mixed hard and granular hematite. 
AREA 34

3,200 square meters of canga rica. Similar to 33 above.

AREA 35

74,000 square meters.

330,000 tons of hematite per meter of depth.

Structure of ore: Mostly soft hematite with only about 30 percent plus 1 inch hard hematite.

AREA 36

160,000 square meters.

720,000 tons hematite per meter of depth.

Structure of ore: Nearly all soft hematite, possibly with 20 percent plus 1 inch.

Observations: Entire area covered by rich, relatively fine grained canga, that is, no large pebbles or cobbles of hematite. The estimate that the entire area is underlain by soft hematite is supported by evidence seen in an excavation for manganese in southern part of the area. About 2 meters of secondary manganese ore overlying at least 4 meters of manganiferous soft hematite is exposed in the pit.

\section{AREA 37}

8,400 square meters of sparse cobbles and boulders of hematite ore. The degree of rounding is unusually high, suggesting that these cobbles have been subjected to weathering far longer than have most such cobbles in other deposits. Because of their dispersal in soil and alluvium, extensive sampling would be necessary in order to arrive at a reasonable estimate of tonnage.

$$
\text { AREA } 3 \mathbf{8}
$$

14,000 square meters of canga rica. This canga rica consists of angular fragments of hard hematite from 2 to 10 centimeters in diameter with a minimum of limonitic cement. 'This may be a crushed and broken hard hematite ore or it may be the surface expression of beds of hard hematite ore, 2-10 centimeters thick, separated by very thin beds of soft hematite ore. Although a tonnage estimate has not been made for this area, the canga rica is at least. 5 meters thick in some places. From its field appearance its grade cannot be much less than that of compact hematite ore : it probably contains about 66 percent iron.

AREA 30

11,000 square meters.

50,000 tons hematite per meter of depth.

Structure of ore: About 40 percent hard hematite and 60 percent soft hematite.

Observations: Outcrop shows mostly platy hematite ore with beds of hard hematite, 5 to 30 centimeters thick.
AREA 40

7,000 square meters of hematite boulders occurring in a narrow band. Angular boulders as much as 50 centimeters in diameter. Hard pink itabirite bounds area 40 on the southwest. Boulders almost surely broken from a thin bed of hard hematite obscured by soil and detritus.

AREA 41

4,500 square meters.

20,000 tons hematite per meter of depth.

Structure of ore : Mostly soft hematite with some platy hematite.

Observations: Only high-grade canga exposed.

AREA +2

15,000 square meters.

68,000 tons of hematite per meter of depth.

Structure of ore : Probably 40 percent large lump hematite with rest platy and soft hematite. Possibly some itabirite present.

Observations: Etching of surface of hard hematite by weathering reveals very thin bedding, 2-20 laminae per centimeter.

AREA 43

11,000 square meters.

50,000 tons of hematite per meter of depth.

Structure or ore: Probably 75 percent large lump hematite, the remainder platy and soft hematite.

Observations: Extension of this ore to 50 meters depth is probably safe, but lateral extension to join adjacent ore bodies is not. Area 43 is only 120 meters from area 52. A vertical diamond-drill hole midway between the edges of the two areas went through 50 meters of soil and alluvium. The hole was abandoned at this depth because, according to the driller's reports, the bit jammed in a boulder of canga.

AREA 44

7,800 square meters.

35,000 tons of hematite per meter of depth.

Structure of ore : Probably 50 percent hard ore of about one-half inch size, 50 percent soft hematite.

Observations: Outcrop is canga consisting of fracture rhombs and thin plates of hard hematite, almost in place, but with each fragment separated from the next by 1-5 millimeters of limonite.

AREA 45

2,600 square meters.

12,000 tons hematite per meter of depth.

Structure of ore : Probably 50 percent soft hematite and 50 percent small lump hematite, $1 / 2$ to 2 inches in size. 
Observations: Area is bounded on the east by a small, but steep-sided, valley that seems physiographically incongruous. The valley probably results from the erosion of a weathered dike.

AREA 46

26,000 square meters of cobbles and boulders of hematite. Concentration of boulders is greater in the southern part of the area than in the northern. Many of the fragments of hematite are angular and are as much as 40 centimeters across.

AREA 47

9,000 square meters.

40,000 tons hematite per meter of depth.

Structure of ore: Probably mostly soft hematite with some platy hematite.

Observations: Area is covered by canga rica whose appearance and structure suggest that it is underlain by platy and soft hematite ore.

AREA $47-A$

97,000 square meters of canga which seems to be intermediate between canga rica and ordinary canga. The appearance of the surface suggests that it is underlain by relatively high grade itabirite containing thin beds and lenses of both hard and soft hematite.

AREA 48

33,000 square meters.

150,000 tons of hematite per meter of depth.

Structure of ore: About 40 percent large lump hematite, mostly in the eastern part of the area. Probably 60 percent mixed soft and platy hematite.

Observations: Boulders of hard hematite ore are as much as 6 meters in diameter.

AREA 49

59,000 square meters of red and yellow soil with scattered, sparse cobbles of hard hematite. Possibly about half a metric ton of hematite per cubic meter of soil.

AREA 50

3,200 square meters.

14,000 tons hematite per meter of depth.

Structure of ore: Possibly 50 percent hard hematite, 50 percent soft hematite.

Observations: An area of canga rica physiographically higher than outcrops of hard hematite in area 51 . It is assumed that the canga rica overlies hard hematite from which it was derived.

AREA 51

5,800 square meters.

26,000 tons of hematite per meter of depth.
Structure of ore: Probably 75 percent hard hematite and 25 percent soft hematite.

Observations: Beds are vertical and highly contorted; trend of the outcrop is N. $10^{\circ} \mathrm{W}$. Analyses of samples from a 2-meter test pit in this area showed: $\mathrm{Fe}$, $65.9 ; \mathrm{P}, 0.10$; insoluble, 0.95 . Ninety-five percent of the material was plus one-half inch, and the leanest material occurred in the -10 mesh fraction.

AREA 52

58,000 square meters.

260,000 tons per meter of depth.

Structure of ore: Platy hematite consisting of thin plates of hard hematite alternating with layers of soft hematite.

Observations: Some relatively rich itabirite is probably present, although no siliceous material was seen on the surface. Analyses of samp'es from three test pits in this area showed the following: $\mathrm{Fe}, 65.9,66.0,55.8$; $\mathrm{P}, 0.09,0.09,0.14$; insoluble, 1.26, 1.26, 3.47.

AREA 53

5,200 square meters.

23,000 tons of hematite per meter of depth.

Structure of ore: Mostly large lump hematite but with many joints and fractures filled with limonite.

Observations: Exposure in pit, 5 meters deep, in boulder field of hard "blue" hematite. Underlying hard hematite is fractured and is coated with yelloworange limonite so that no piece shows the "blue" color of surface boulders. Samples from another pit, 3 meters deep, have an iron content of about 58 percent.

AREA 54

14,000 square meters.

63,000 tons hematite per meter of depth.

Structure of ore: Vuggy, schistose hard hematite. Probably about 30 percent plus one-half inch ore, 70 percent soft hematite.

Observations: Judging by the friability of the schistose ore, a large part of the lump would probably disintegrate during shipping. A test pit just west of the area exposes material containing 60.6 percent iron.

AREA $\mathbf{5 5}$

8,400 square meters of scattered hematite boulders of large size. Source is probably in areas 52 and 53. A three-meter test pit shows limonitic, ocherous canga containing only 56.2 percent iron beneath the boulders.

AREA 56

25,000 square meters.

110,000 tons of hematite per meter of depth.

Structure of ore: About 75 percent hard hematite, 25 percent soft hematite. 
Observations: The hard hematite at the surface is sheared, contorted, and schistose. Figure 39 is a nearvertical view of this hematite.

The St. John del Rey Mining Co. put down two diamond-drill holes at the southwest end of the outcrop in area 56. The first hole, designated DDH 2, was drilled northward at a dip of $65^{\circ}$; the second hole, DDH 3, was drilled vertically from the same locality.

Table 19 below shows the results of analyses of cores and sludges from these two drill holes.

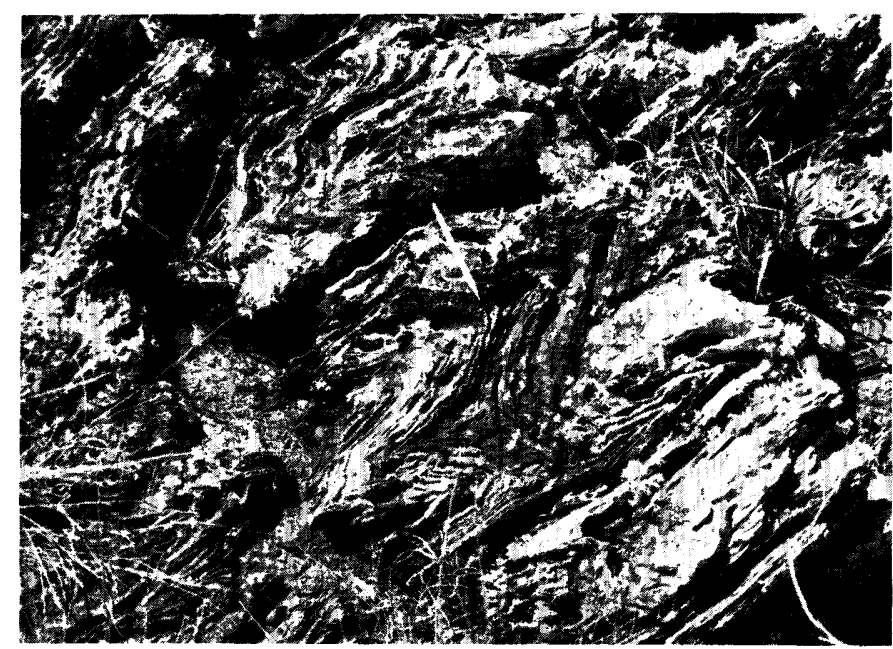

Frgure 39.-Vertical view of contorted, hard laminated hematite ore. Capitão do Mato Norte. Pencil is 13 centimeters long.

TABLE 19.-Analyses of drill cores and sludges from two holes drilled in area 56, Capitão do Mato Norte

\begin{tabular}{|c|c|c|c|c|}
\hline \multicolumn{2}{|c|}{ Meters } & \multicolumn{2}{|c|}{ Percent } & \multirow{2}{*}{ Material } \\
\hline From- & To- & $\mathrm{Fe}$ & $P$ & \\
\hline \multicolumn{5}{|c|}{ Diamond-drill hole 2} \\
\hline \begin{tabular}{r|}
0 \\
1 \\
2 \\
3 \\
4 \\
5 \\
6 \\
7 \\
8 \\
9 \\
10 \\
11 \\
12 \\
13 \\
14 \\
15 \\
16 \\
17 \\
18 \\
19 \\
20 \\
21 \\
22 \\
23 \\
24 \\
25
\end{tabular} & $\begin{array}{l}1 \\
2 \\
3 \\
4 \\
5 \\
6 \\
7 \\
8 \\
9 \\
10 \\
11 \\
12 \\
13 \\
14 \\
15 \\
16 \\
17 \\
18 \\
19 \\
20 \\
21 \\
22 \\
23 \\
24 \\
25 \\
26\end{array}$ & $\left.\begin{array}{l}59.5 \\
65.7 \\
69.1 \\
68.9 \\
69.3 \\
69.5 \\
68.7 \\
68.1 \\
67.6 \\
63.1 \\
65.2 \\
68.1 \\
68.2 \\
69.1 \\
69.6 \\
69.3 \\
69.0 \\
69.0 \\
69.4 \\
69.2 \\
69.7 \\
69.0 \\
68.5 \\
68.6 \\
69.0 \\
67.6\end{array}\right\}\left\{\begin{array}{r}\mid \\
67.6\end{array}\right\}$ & $\begin{array}{r}0.28 \\
.06 \\
.04 \\
.07 \\
.19 \\
.14 \\
.06 \\
.06 \\
.05 \\
.06 \\
.08 \\
.04 \\
.14\end{array}$ & $\begin{array}{l}\text { Hard hematite. } \\
\text { Do. } \\
\text { Do. } \\
\text { Do. } \\
\text { Do. } \\
\text { Do. } \\
\text { Do. } \\
\text { Do. } \\
\text { Do. } \\
\text { Do. } \\
\text { Hard hematite. } \\
\text { Do. } \\
\text { Do. }\end{array}$ \\
\hline
\end{tabular}

TABLE 19.-Analyses of drill cores and sludges from two holes drilled in area 56, Capitão do Mato Norte-Continued

\begin{tabular}{c|c|c|c|c}
\hline \multicolumn{2}{c|}{ Meters } & \multicolumn{2}{|c|}{ Percent } \\
\hline From- & To- & Fe & $P$ & Material \\
\hline
\end{tabular}

Diamond-drill hole 2-Continued

\begin{tabular}{|c|c|c|c|c|}
\hline $\begin{array}{l}26 \\
27 \\
28 \\
29 \\
30 \\
38 \\
42 \\
42.7 \\
45.3 \\
46 \\
47 \\
48 \\
49 \\
50 \\
51 \\
52 \\
53 \\
54 \\
55 \\
56 \\
57 \\
58 \\
59 \\
60 \\
61 \\
62 \\
63 \\
64 \\
65 \\
66 \\
67 \\
68 \\
69 \\
70 \\
72 \\
73 \\
74 \\
75 \\
76 \\
78 \\
80\end{array}$ & $\begin{array}{l}27 \\
28 \\
29 \\
30 \\
38 \\
42 \\
42.7 \\
45.3 \\
46 \\
47 \\
48 \\
49 \\
50 \\
51 \\
52 \\
53 \\
54 \\
55 \\
56 \\
57 \\
58 \\
59 \\
60 \\
61 \\
62 \\
63 \\
64 \\
65 \\
66 \\
67 \\
68 \\
69 \\
70 \\
72 \\
73 \\
74 \\
75 \\
76 \\
78 \\
80 \\
81\end{array}$ & $\left.\begin{array}{l}68.0 \\
67.2 \\
66.4 \\
65.0 \\
66.7 \\
68.2 \\
65.8 \\
66.7 \\
66.1 \\
66.9 \\
66.8 \\
67.7 \\
68.2 \\
68.6 \\
68.9 \\
68.3 \\
69.4 \\
69.4 \\
69.1 \\
68.7 \\
68.9 \\
69.0 \\
699.2 \\
69.4 \\
69.2 \\
68.8 \\
69.3 \\
69.3 \\
69.3 \\
69.2 \\
69.0 \\
69.1 \\
68.8 \\
69.0 \\
68.5 \\
68.2 \\
67.7 \\
67.7 \\
66.2 \\
67.4\end{array}\right\}$ & $\begin{array}{l}0.06 \\
.04 \\
.11 \\
.11 \\
.22 \\
.08 \\
.04 \\
.07 \\
.05 \\
.03 \\
.07 \\
.05 \\
.05 \\
.03 \\
.03 \\
.03 \\
.03 \\
.02 \\
.05 \\
.03 \\
.04 \\
.04 \\
.09 \\
.03\end{array}$ & $\begin{array}{l}\text { Hard hematite. } \\
\text { Do. } \\
\text { Soft hematite. } \\
\text { Do. } \\
\text { Do. } \\
\text { Hard hematite. } \\
\text { Do. } \\
\text { Do. } \\
\text { Do. } \\
\text { Do. } \\
\text { Do. } \\
\text { Mixed hard and soft hematite. } \\
\text { Do. } \\
\text { Hard hematite. } \\
\text { Do. } \\
\text { Do. } \\
\text { Do. } \\
\text { Mixed hard and soft hematite. } \\
\text { Do. } \\
\text { Hard hematite. } \\
\text { Soft hematite. } \\
\text { Do. } \\
\text { Do. } \\
\text { Do. } \\
\text { Do. }\end{array}$ \\
\hline
\end{tabular}

Diamond-drill hole 3

\begin{tabular}{|c|c|c|c|c|}
\hline $\begin{array}{r}0 \\
1 \\
2 \\
3 \\
4 \\
5 \\
6 \\
7 \\
8 \\
9 \\
10 \\
11 \\
12 \\
13 \\
14\end{array}$ & $\begin{array}{r}1 \\
2 \\
3 \\
4 \\
5 \\
6 \\
7 \\
8 \\
9 \\
10 \\
11 \\
12 \\
13 \\
14 \\
15.25\end{array}$ & $\begin{array}{l}66.9 \\
66.5 \\
62.2 \\
66.2 \\
61.1 \\
64.2 \\
67.0 \\
67.6 \\
68.3 \\
67.8 \\
68.5 \\
68.3 \\
68.8 \\
68.1 \\
68.3\end{array}$ & $\begin{array}{r}0.13 \\
.24 \\
.10 \\
.06 \\
.06 \\
.04 \\
.06 \\
.06\end{array}$ & $\begin{array}{l}\text { Canga. } \\
\text { Do. } \\
\text { Do. } \\
\text { Do. } \\
\text { Soft hematite. } \\
\text { Do. } \\
\text { Soft hematite. } \\
\text { Do. }\end{array}$ \\
\hline \multicolumn{5}{|c|}{ Sludge, diamond-drill hole 2} \\
\hline $\begin{array}{l}0 \\
11 \\
33 \\
42.7\end{array}$ & $\begin{array}{l}3.35 \\
13 \\
36 \\
45.3\end{array}$ & $\begin{array}{l}61.1 \\
62.3 \\
61.1 \\
57.7\end{array}$ & $\begin{array}{r}0.26 \\
.21 \\
.14 \\
.30\end{array}$ & \\
\hline \multicolumn{5}{|c|}{ Sludge, diamond-drill hole 3} \\
\hline $\begin{array}{r}1.2 \\
4.2 \\
7.2 \\
10.2 \\
13.2\end{array}$ & $\begin{array}{c}4.2 \\
7.2 \\
10.2 \\
13.2 \\
15.25\end{array}$ & $\begin{array}{l}58.4 \\
57.8 \\
58.2 \\
58.5 \\
58.4\end{array}$ & $\begin{array}{r}0.38 \\
.35 \\
.99 \\
.39 \\
.38\end{array}$ & \\
\hline
\end{tabular}


These drill holes are important because at the time of this writing (mid-1958) they furnished the only deep subsurface samples in the entire Capitão do Mato area.

The iron content of the cores is uniformly high, generally about 67 to 69 percent. Analyses of the sludges of DDH 2 suggest that the quartz and much of the phosphorus-bearing mineral are carried to the surface by returning drill water, whereas the hematite remains below. Thus it seems that rock in place will contain somewhat less iron and somewhat more insoluble material than drill samples might indicate. On the other hand, the fact that the act of drilling could so readily concentrate the iron mineral suggests that an equally simple beneficiation process could be applied after mining.

Drill holes have revealed that the ore in area $56 \mathrm{ex}$ tends at least 75 meters below outcrop. Taking this as the depth factor, multiplying by the area of 25,000 square meters and then multiplying by the specific gravity of 4.5 , results in an estimated reserve of 8.5 million tons of indicated ore.

Analyses of samples from four pits in this area show the following (from north to south):

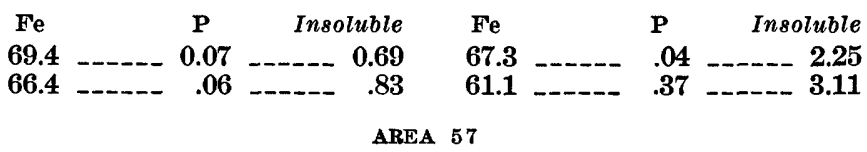

7,700 square meters.

35,000 tons of hematite per meter of depth.

Structure of ore: About 30 percent hard hematite of more than $1 / 2$-inch; 70 percent hematite of less than one half inch.

Observations: Highly contorted; powdery texture visible in outcrops.

3,200 square meters.

AREA 58

14,000 tons hematite per meter of depth.

Structure of ore: Probably 50 percent of plus one-halfinch hard hematite, 50 percent, soft hematite.

1,900 square meters.

AREA $5 \boldsymbol{9}$

8,500 tons hematite per meter of depth.

Structure of ore: About 50 percent hard schistose hematite, 50 percent, soft hematite.

15,000 square meters.

AREA 60

67,000 tons hematite per meter of depth.

Structure of ore: Probably about 50 percent hard lump hematite, 50 percent soft hematite under canga rica.

18,000 square meters.

81,000 tons hematite per meter of depth.

Structure of ore: Probably mostly soft ore under canga.
AREA 62

54,000 square meters of hematite boulders in soil. Probably not more than half a metric ton of hematite per cubic meter of soil.

AREA 63

6,400 square meters.

29,000 tons of hematite per meter of depth.

Structure of ore: About 50 percent, large lump hematite, and about 50 percent, minus one-half inch hematite.

AREA 64

18,000 square meters of canga, canga rica, and hematite boulders; in part probably overlying hematite.

AREA 65

9,100 square meters of cobbles and boulders of hard hematite, probably overlying mixed hard and soft ore. Analyses of samples from a 3.5 meter test pit in this area show an iron content of 66.1 percent, $\mathrm{P}, 0.19$ percent, and insoluble, 1.05 percent. Screening of the material showed that 59 percent was more than one-half inch.

AREA 66

35,000 square meters.

160,000 tons of hematite per meter of depth.

Structure of ore: About 30 percent hard hematite and 70 percent soft hematite.

Observations: Analyses of samples from three pits dug in this area showed the following:

\begin{tabular}{lrrrc}
$\begin{array}{c}\text { Vertical sample } \\
\text { interval (meters) }\end{array}$ & $\mathrm{Fe}$ & $\mathrm{P}$ & Insoluble & $\begin{array}{c}\text { Percent more than } \\
\text { one half-inch size }\end{array}$ \\
$0-3$ & 61.8 & 0.15 & 1.58 & 53 \\
$0-3$ & 60.5 & .13 & 1.58 & 51 \\
$3-5$ & 60.8 & .19 & 1.05 & 19 \\
& \multicolumn{2}{c}{ AREA 67}
\end{tabular}

38,000 square meters of sparse hematite boulders over itabirite, that possibly contains pods and lenses of compact hematite.

AREA 68

6,400 square meters.

29,000 tons of hematite per meter of depth.

Structure of ore: About 75 percent hard hematite.

Observations: A pit in this area, sampled from a depth of 3 meters to 4.5 meters, showed an iron content of 69.5 percent; $\mathrm{P}, 0.06$ percent; and insoluble, 0.69 percent.

AREA 69

10,000 square meters.

45,000 tons of hematite per meter of depth.

Structure of ore: About 75 percent hard hematite and 25 percent soft hematite. 
AREA 70

12,000 square meters of canga rica, probably mostly cemented talus from area 59. The thickness is unknown, but it is not likely to exceed 5 meters.

$$
\text { AREAS } 71-72
$$

120,000 square meters.

540,000 tons hematite per meter of depth.

Structure of ore: Dominantly soft platy hematite in area 71, and schistose hard hematite in area 72.

Observations: Boundaries of these areas are indefinite. Outcrop of soft, platy hematite merges into highgrade canga which in turn merges into ordinary canga.

AREA 73

1,900 square meters.

8,500 tons per meter of depth.

Structure of ore: Probably 75 percent hard hematite.

AREA 74

3,800 square meters of canga rica that may overlie rich platy hematite ore containing some lenses of hard ore.

AREA 75

27,000 square meters.

120,000 tons of hematite per meter of depth.

Structure of ore: Probably mostly soft hematite with some zones of platy or mixed hard and soft hematite.

AREA 76

1,900 square meters.

8,500 tons of hematite per meter of depth.

Structure of ore: About 50 percent hard hematite and 50 percent soft hematite.

AREA 77

45,000 square meters of canga rica, probably derived from hard hematite in areas 76 and 78.

AREA 78

26,000 square meters.

120,000 tons of hematite per meter of depth.

Structure of ore: About 75 percent hard hematite.

AREA 79

10,000 square meters of canga rica similar to that in area 77 and probably derived mainly from talus from outcrops of hematite ore in areas 75 and 76 .

AREA 80

26,000 square meters of canga rica and cobbles and boulders of hematite ore. Probably overlies mixed hard and soft hematite ore. Loose cobbles and boulders of ore in a layer about 20 to 50 centimeters thick over canga rica.
5,200 square meters.

AREA 81

23,000 tons of hematite per meter of depth.

Structure of ore: Mostly soft hematite with some layers of schistose hematite.

\section{AREA 82}

13,000 square meters of rounded cobbles of hard hematite. Area is covered by cobbles, 5 to 10 centimeters in diameter, with no interstitial soil. The thickness of the deposit is not known but is probably less than one meter. The deposit may overlie canga rica formed by cementation of similar cobbles.

AREA 83

7,800 square meters.

35,000 tons of hematite per meter of depth.

Structure of ore : Probably about 75 percent hard hematite.

Observations: The canga between areas 82 and 83 is very rich in iron and possibly should be classified as canga rica. Considerable soft hematite ore may underlie the canga in this general area.

\section{AREA 84}

9,700 square meters of canga rica, in part certainly derived from the breaking down of nearby bedrock ore. May also be, in part, recemented mixture of hard and soft hematite from underlying sources.

AREA 85

5,100 square meters.

23,000 tons of hematite per meter of depth.

Structure of ore: Probably 75 percent soft hematite and 25 percent of plus one-half inch hard ore.

AREA 86

3,900 square meters.

18,000 tons of hematite per meter of depth.

Structure of ore: Probably 75 percent hard hematite.

7,700 square meters.

$$
\text { AREA } 87
$$

35,000 tons of hematite per square meter.

Structure of ore: Probably 75 percent soft hematite.

AREA 88

2,600 square meters.

12,000 tons of hematite per square meter.

Structure of ore: Probably 50 percent soft and 50 percent of plus one-half inch hard hematite.

\section{AREA 89}

16,000 square meters.

72,000 tons of hematite per meter of depth.

Structure of ore: Schistose hematite, probably 50 percent flaky powder, and 50 percent rather friable lump. 
AREA 90

32,000 square meters.

140,000 tons of hematite per meter of depth.

Structure of ore: Probably 70 percent soft hematite, 30 percent granular and schistose friable hematite that would break down into finer material in mining, handling, and shipping.

AREA 91

4,500 square meters.

22,000 tons of hematite per meter of depth.

Structure of ore: About 75 percent hard lump hematite, and 25 percent minus one-half inch soft ore.

AREA 92

12.000 square meters of canga rica and loose boulders and cobbles of hard hematite. Probably overlying body of mixed hard and soft ore.

AREA 93

9,700 square meters of canga rica, and loose boulders and cobbles of hard hematite ore. Like 92 above, this probably overlies a body of mixed hard and soft ore.

\section{AREA 94}

48,000 square meters of canga rica and cobbles of hematite within the boundary of the Tamanduá-Capitão do Mato-Serra da Gama map. Area 94 actually extends a considerable distance north of the region covered by this special map (see fig. 4, map of the Macacos quadrangle). The canga rica of area 94 is generally between 2 and 10 meters thick overlying the Cauê itabirite, the Batatal and Moeda formations, and rocks of the Nova Lima group of the Rio das Velhas series.

3,200 square meters.

14,000 tons of hematite per meter of depth.

Structure of ore: Schistose hard hematite, 30 to 60 percent of which would probably break down into fine material during mining, handling, and shipping.

9,700 square meters.

AREA 96

31,000 tons of hematite per meter of depth.

Structure of ore: About 50 percent massive hematite and 50 percent granular soft ore.

AREA 97

9,000 square meters of cobbles of hard hematite, probably over canga rica which may overlie mixed hard and soft ore.

SUMMARY OF THE TAMANDUÁ-CAPTTÃo Do MATO-SERRA DA GAMA REGION

An estimate, in tons per meter of depth, has been made for each of the areas believed to overlie bedrock hematite ore. The total of all the individual estimates is about 4.7 million tons of hematite per meter of depth.

Most of these individual deposits probably extend to at least 50 meters depth. Elsewhere in the Quadrilátero Ferrífero, as at Pico Itabira, hematite ore bodies have been proved to extend to 200 meters below outcrop. Area 56 contains the only individual deposit in the Tamanduá-Capitão do Mato-Serra da Gama region for which there is information at depth. This deposit extends downward at least 75 meters and therefore contains at least 8.2 million tons of indicated hematite ore. Many other individual deposits of this region are probably of similar depth.

Areas of canga rica and of boulders of hematite cannot always be related to underlying ore bodies; for this reason their extent in square meters has been stated.

The total of such areas in the Tamanduá-Capitão do Mato-Serra da Gama region is about 690,000 square meters.

TABLE 20.-Ore estimate for Tamanduá-Capitão do Mato-Serra da Gama, Macacos quadrangle

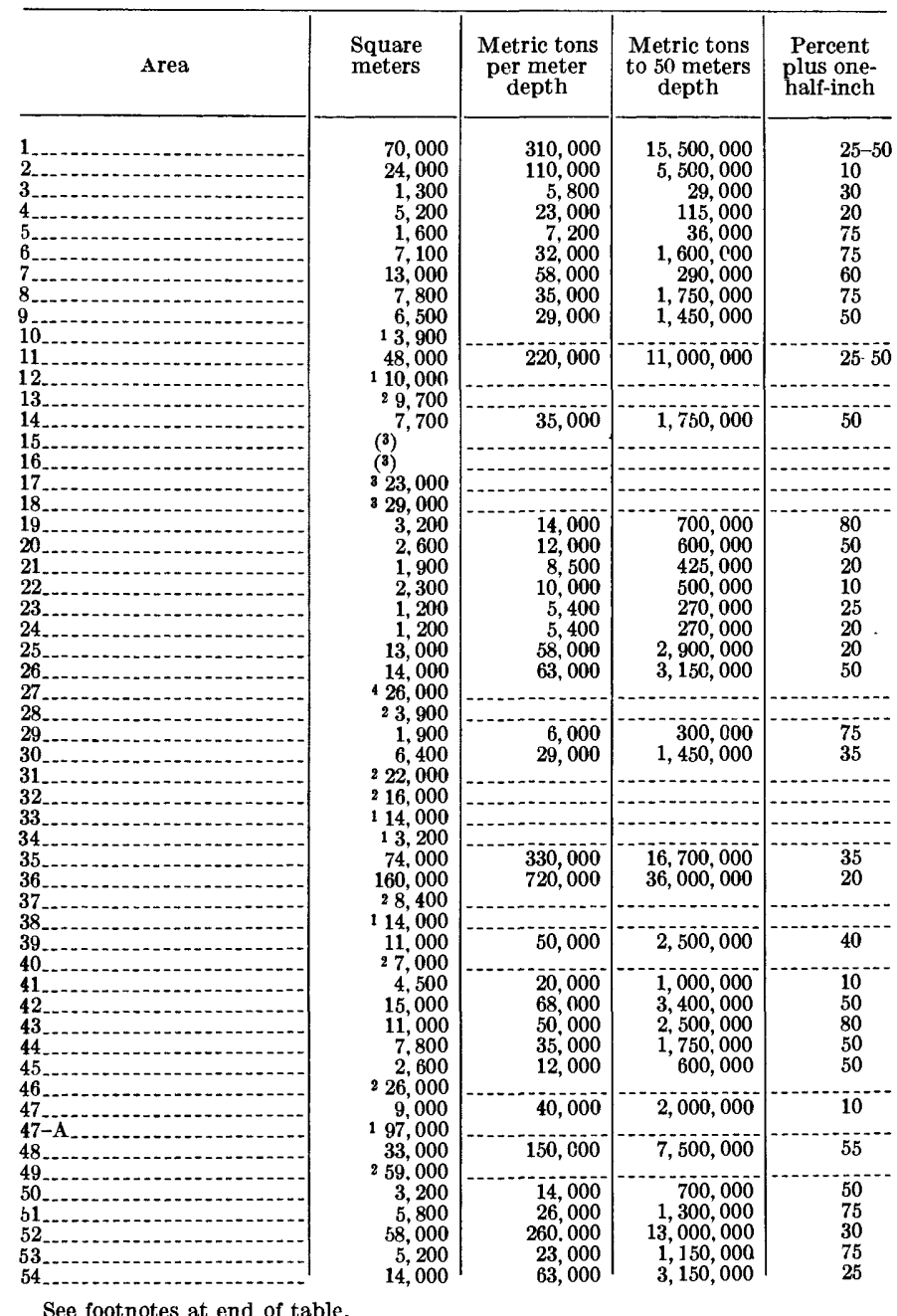


TABLE 20.-Ore estimate for Tamanduá-Capitão do Mato-Serra la Gama, Macacos quadrangle-Continued

\begin{tabular}{|c|c|c|c|c|}
\hline Area & $\begin{array}{l}\text { Square } \\
\text { meters }\end{array}$ & $\begin{array}{l}\text { Metric tons } \\
\text { per meter } \\
\text { depth }\end{array}$ & $\begin{array}{l}\text { Metric tons } \\
\text { to 50 meters } \\
\text { depth }\end{array}$ & $\begin{array}{l}\text { Percent } \\
\text { plus one- } \\
\text { half-inch }\end{array}$ \\
\hline \multirow{2}{*}{55} & \multirow{11}{*}{$\begin{array}{r}28,400 \\
25,000 \\
7,700 \\
3,200 \\
1,900 \\
15,000 \\
18,000 \\
254,000 \\
6,400 \\
118,000 \\
29,100 \\
35,000 \\
238,000 \\
6,400 \\
10,000 \\
112,000\end{array}$} & & & \\
\hline & & 110,000 & $\$ 13,700,000$ & 75 \\
\hline & & 0 & $\begin{array}{r}1,750,000 \\
700,000\end{array}$ & 30 \\
\hline & & & & \\
\hline & & & & \\
\hline & & & 4,0 & 10 \\
\hline & & 29,000 & $1,450,000$ & 50 \\
\hline & & & 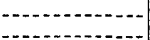 & \\
\hline & & 160,000 & $8,000,000$ & 30 \\
\hline & & $\begin{array}{l}29,000 \\
45,000\end{array}$ & $\begin{array}{l}1,450,000 \\
2,250,000\end{array}$ & $\begin{array}{l}75 \\
75\end{array}$ \\
\hline \multirow{2}{*}{$77^{71-72}$} & & & & \\
\hline & $\begin{array}{r}120,000 \\
1,900 \\
3,800\end{array}$ & $\begin{array}{r}540,000 \\
8,500\end{array}$ & $\begin{array}{r}27,000,000 \\
425,000\end{array}$ & 30 \\
\hline 76 & $\begin{array}{r}\mathbf{5}, 000 \\
1,900\end{array}$ & $\begin{array}{r}120,000 \\
8,500\end{array}$ & $\begin{array}{r}6,100,000 \\
425,000\end{array}$ & 50 \\
\hline \multirow{2}{*}{78} & $\begin{array}{r}145,000 \\
26,000\end{array}$ & 120,000 & $5,850,000$ & $50-75$ \\
\hline & 110,000 & & & \\
\hline \multirow{2}{*}{80} & $\begin{array}{r}126,000 \\
5,200\end{array}$ & 23,000 & $1,150,000$ & 10 \\
\hline & 213,000 & & & \\
\hline \multirow{2}{*}{848} & $\begin{array}{r}7,800 \\
19,700\end{array}$ & 35,000 & $1,750,000$ & 75 \\
\hline & 5,100 & & $1,150,000$ & \\
\hline & $\begin{array}{l}3,900 \\
7,700\end{array}$ & $\begin{array}{l}18,000 \\
35,000\end{array}$ & & $\begin{array}{l}75 \\
25\end{array}$ \\
\hline \multirow{2}{*}{8989} & 2,600 & 12, & & \\
\hline & 16,000 & 72,000 & & \\
\hline \multirow{2}{*}{92} & $\begin{array}{r}32,000 \\
4,500\end{array}$ & $\begin{array}{r}140,000 \\
22,000\end{array}$ & $1,100,000$ & 75 \\
\hline & $\begin{array}{r}112,000 \\
19,700\end{array}$ & & . & \\
\hline \multirow{3}{*}{95} & 148,000 & & & \\
\hline & $\begin{array}{l}3,200 \\
9,700\end{array}$ & & 00 & 50 \\
\hline & 29,000 & & & \\
\hline Rounded total & & $4,700,000$ & $240,000,000$ & \\
\hline
\end{tabular}

1 Canga rica, no reserve estimate.

2 Rolados, hematite boulders, and cobbles, no reserve estimate.

3 Several huge boulders, may be shifted outcrop.

5 Sum of indicated ore and inferred ore. Drilling in area 56 shows ore to 75 meters below outcrop $-75 \times 110,000=8,200,000$ tons indicated ore. Material 50 meters below lowest exploration, $50 \times 110,000=5,500,000$ tons inferred ore.

TABLE 21.-Summary of hematite ore reserves in the Belo Horizonte, Ibirité, and Macacos quadrangles, Minas Gerais, Brazil

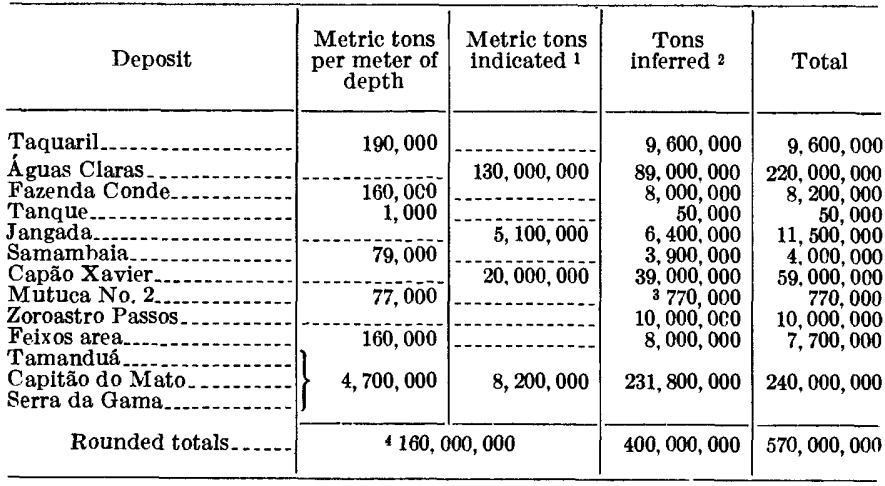

1 Above lowest outcrop or lowest exploration.

50 meters below lowest outcrop or lowest exploration.

Combined total of tons per meter of depth and

\section{BAUXITE}

Chemical canga grades imperceptibly into hard material whose $\mathrm{Al}_{2} \mathrm{O}_{3}$ content is so high that it should be described as ferruginous bauxite rather than canga. This material was thought to be canga until chemical analyses showed that it is dominantly aluminous rather than ferruginous. No exposure of this material is known to be over 50 centimeters thick.

The bauxite being mined in the Macacos quadrangle in the vicinity of N. 8,000, E. 2,500 in 1958 is soft material beneath a layer of hard aluminous canga. It is soft enough to be mined with pick and shovel.

The Departmento Nacional da Produção Mineral put down two diamond-drill holes (see Macacos quadrangle map). Analyses of the sludge and core samples are shown in tables 22 and 23.

The St. John del Rey Mining Co. explored this bauxite deposit a few years ago by a series of shallow drill holes. Logs of these holes are not available, but the company determined reserves of about 600,000 tons of bauxite for the northern area (see Macacos quadrangle) and about 200,000 tons of bauxite for the southern area. The bauxite is not of high quality as is shown by the analyses of 13 samples (table 24). The northern is much the better of the two areas; $\mathrm{Al}_{2} \mathrm{O}_{3}$ is about 43 percent, $\mathrm{Fe}_{2} \mathrm{O}_{3}$, about 3 percent, and $\mathrm{TiO}_{2}$, less than 0.1 percent. The bauxite of the southern area contains about 39 percent $\mathrm{Al}_{2} \mathrm{O}_{3}$, and much more $\mathrm{Fe}_{2} \mathrm{O}_{3}$ and $\mathrm{TiO}_{2}$.

TABLE 22.-Analyses of sludge and core samples from the $\mathrm{M} u$ tuca diamond-drill hole 1, Macacos N. 8,160, E. 2,600

$\left[\mathrm{TiO}_{2}\right.$ less than 0.1 percent in all samples. Analyzed in the laboratory of the Departamento Nacional da Produęão Mineral, Rio de Janeiro, by: ESM, Ewaldo da Silva Moreira, Bull. 12645, 23 March 1955, AE, Aida Espinola, Bull. 12649, 25 March probably in the range of 0.4 to 0.5$]$

\begin{tabular}{|c|c|c|c|c|c|c|c|}
\hline Depth in meters & $\mathrm{Al}_{2} \mathrm{O}_{3}$ & $\mathrm{Fe}_{2} \mathrm{O}_{3}$ & $\mathrm{Fe}$ & $\mathrm{P}_{2} \mathrm{O}_{3}$ & Insol. & $\begin{array}{c}\text { Loss in } \\
\text { ignition }\end{array}$ & Analyst \\
\hline $\begin{array}{r}0-3.05 \\
3.05-6.10 \\
6.10-9.15 \\
9.15-12.20 \\
12.20-15.25 \\
15.25-18.30 \\
\text { at- } 17.80 \\
18.30-21.4 \\
21.35-27.43 \\
\text { at- } 24.4 \\
27.43-30.53 \\
30.53-33.58 \\
33.58-36.63 \\
36.63-39.68 \\
39.68-42.67 \\
\text { at- } 42.7 \\
42.67-45.72 \\
45.72-48.77 \\
48.77-51.82 \\
51.82-54.87 \\
54.87-57.92 \\
57.92-60.97 \\
60.97-64.02 \\
64.02-67.07 \\
67.07-70.12 \\
70.12-75.20 \\
75.20-78.00 \\
78.00-80.20 \\
\end{array}$ & $\begin{array}{l}44.8 \\
47.0 \\
42.2 \\
39.0 \\
42.3 \\
44.0 \\
41.4 \\
44.0 \\
41.1 \\
41.2 \\
38.7 \\
41.1 \\
43.3 \\
42.1 \\
38.6 \\
39.0 \\
37.9 \\
34.6 \\
21.3 \\
17.7 \\
18.2 \\
9.9 \\
15.9 \\
24.9 \\
1.3 \\
3.6 \\
3.1\end{array}$ & $\begin{array}{r}28.3 \\
4.7 \\
3.4 \\
3.1 \\
2.6 \\
3.4 \\
1.0 \\
2.4 \\
3.1 \\
1.3 \\
2.0 \\
2.1 \\
.5 \\
.6 \\
2.4 \\
2.6 \\
2.7 \\
11.7 \\
36.6 \\
43.4 \\
48.2 \\
63.5 \\
27.2 \\
40.4 \\
87.2 \\
68.1 \\
64.2\end{array}$ & $\begin{array}{r}19.7 \\
3.3 \\
2.4 \\
2.2 \\
1.8 \\
2.4 \\
.7 \\
1.7 \\
2.2 \\
.9 \\
1.4 \\
1.5 \\
.4 \\
.4 \\
1.7 \\
1.8 \\
1.9 \\
8.2 \\
25.5 \\
30.3 \\
33.8 \\
44.5 \\
19.1 \\
28.2 \\
61.0 \\
47.8 \\
45.0\end{array}$ & $\begin{array}{r}<0.5 \\
.6 \\
.4 \\
.4 \\
<.5 \\
<.5 \\
.4 \\
<.5 \\
.4 \\
.3 \\
.4 \\
.4 \\
<.5 \\
.4 \\
\operatorname{Tr} . \\
\text { Tr. } \\
\text { Tr. } \\
\text { Tr. } \\
<.5 \\
<.5 \\
<0.5 \\
<.5 \\
\text { Tr. } \\
<.5 \\
<.5 \\
<.5 \\
.4\end{array}$ & $\begin{array}{r}1.4 \\
28.5 \\
38.6 \\
39.1 \\
38.0 \\
36.0 \\
42.1 \\
37.0 \\
39.8 \\
42.6 \\
44.4 \\
41.9 \\
41.5 \\
42.6 \\
42.7 \\
42.6 \\
41.0 \\
37.6 \\
29.6 \\
27.3 \\
20.8 \\
13.0 \\
43.0 \\
21.2 \\
3.6 \\
20.3 \\
23.3\end{array}$ & $\begin{array}{l}25.2 \\
19.5 \\
15.9 \\
19.0 \\
15.7 \\
16.3 \\
15.4 \\
16.0 \\
15.6 \\
15.0 \\
15.0 \\
14.9 \\
15.0 \\
14.8 \\
15.3 \\
15.3 \\
16.1 \\
14.7 \\
12.3 \\
11.6 \\
12.5 \\
11.3 \\
12.9 \\
13.0 \\
8.1 \\
8.0 \\
8.3\end{array}$ & $\begin{array}{l}\text { ESM } \\
\text { AE } \\
\text { AE } \\
\text { AE } \\
\text { ESM } \\
\text { ESM } \\
\text { AE } \\
\text { ESM } \\
\text { AE } \\
\text { AE } \\
\text { AE } \\
\text { AE } \\
\text { ESM } \\
\text { AE } \\
\text { MYER } \\
\text { MYER } \\
\text { MYER } \\
\text { MYER } \\
\text { ESM } \\
\text { ESM } \\
\text { ESM } \\
\text { ESM } \\
\text { MYER } \\
\text { ESM } \\
\text { ESM } \\
\text { ESM } \\
\text { MYER }\end{array}$ \\
\hline $\begin{array}{r}78.00-80.20 \\
90.13-90.13 \\
97.00-102.00 \\
102.00-113.00\end{array}$ & $\begin{array}{r}.0 \\
1.3 \\
.4 \\
.0\end{array}$ & $\begin{array}{l}91.5 \\
89.4 \\
80.9 \\
93.6\end{array}$ & $\begin{array}{l}64.0 \\
62.5 \\
56.4 \\
65.6\end{array}$ & $\begin{array}{l}<.5 \\
<.5 \\
<.5 \\
<.5\end{array}$ & $\begin{array}{l}4.1 \\
3.1 \\
1.7 \\
2.7\end{array}$ & $\begin{array}{r}4.7 \\
6.4 \\
17.1 \\
4.4\end{array}$ & $\begin{array}{l}\text { ESM } \\
\text { ESM } \\
\text { ESM } \\
\text { ESM }\end{array}$ \\
\hline
\end{tabular}

1 No sample. 
TABLE 23.-Analyses, in percent, of sludge and core samples from the Mutuca DDH 2, Macacos N. 8,100, E, 1,950

Analyzed in the laboratory of the Departamento Nacional da Producao Mineral, Rio de Janeiro, by: FCM, Francisco Coutinho de Matos, Bull. 12855, 14 June 1955, 18 August 1955]

\begin{tabular}{|c|c|c|c|c|c|c|c|}
\hline Depth in meters & $\mathrm{Al}_{2} \mathrm{O}_{3}$ & $\mathrm{Fe}_{2} \mathrm{O}_{3}$ & $\mathrm{TiO}_{2}$ & $\mathrm{P}_{2} \mathrm{O}_{5}$ & $\mathrm{SiO}_{2}$ & $\begin{array}{l}\text { Other } \\
\text { insol. }\end{array}$ & $\begin{array}{c}\text { Loss in } \\
\text { ignition }\end{array}$ \\
\hline \multicolumn{8}{|c|}{ Analyst FCM } \\
\hline $\begin{array}{r}0-3.05 \\
3.05-6.10 \\
6.10-\quad 9.15 \\
9.15-12.20 \\
12.20-15.25 \\
\text { at } 15.2 \ldots \\
15.25-18.30 \\
18.30-21.35 \\
21.35-24.40 \\
24.40-27.45 \\
27.45-30.50 \\
\text { at } 29.0 \\
30.50-33.55 \\
33.55-36.60\end{array}$ & $\begin{array}{l}29.1 \\
34.4 \\
38.7 \\
39.4 \\
38.4 \\
46.8 \\
39.6 \\
39.6 \\
38.3 \\
36.6 \\
31.1 \\
45.0 \\
35.8 \\
19.3\end{array}$ & $\begin{array}{r}44.3 \\
37.4 \\
19.8 \\
13.7 \\
11.8 \\
8.6 \\
11.6 \\
6.4 \\
6.3 \\
9.0 \\
12.7 \\
5.5 \\
11.7 \\
37.2\end{array}$ & $\begin{array}{r}1.2 \\
.8 \\
.8 \\
.8 \\
.8 \\
2.5 \\
.8 \\
2.0 \\
2.5 \\
2.3 \\
2.7 \\
2.3 \\
2.3 \\
1.4\end{array}$ & $\begin{array}{l}0.26 \\
.17 \\
.12 \\
.17 \\
.2 \\
.15 \\
.18 \\
.18 \\
.17 \\
.17 \\
.13 \\
.2 \\
.14 \\
.17\end{array}$ & $\begin{array}{r}6.0 \\
7.4 \\
21.3 \\
29.4 \\
32.9 \\
38.4 \\
32.3 \\
36.3 \\
37.1 \\
36.5 \\
38.7 \\
41.6 \\
37.2 \\
31.2\end{array}$ & $\begin{array}{r}0.8 \\
.4 \\
1.5 \\
.7 \\
.5 \\
.7 \\
.2 \\
1.0 \\
.9 \\
1.0 \\
1.4 \\
.8 \\
.9 \\
.7\end{array}$ & $\begin{array}{r}17.7 \\
20.0 \\
18.5 \\
16.4 \\
16.0 \\
10.0 \\
16.0 \\
15.0 \\
15.0 \\
15.0 \\
13.5 \\
4.0 \\
12.0 \\
10.0\end{array}$ \\
\hline \multicolumn{8}{|c|}{ Analyst NM } \\
\hline $\begin{array}{l}36.60-39.65 \\
39.65-42.70 \\
42.70-45.75 \\
45.75-48.80 \\
48.00-49.00 \\
48.80-51.85\end{array}$ & \begin{tabular}{l|l}
30.4 \\
31.0 \\
24.9 \\
13.1 \\
32.5 \\
11.0
\end{tabular} & $\begin{array}{r}15.7 \\
18.6 \\
8.7 \\
5.8 \\
31.0 \\
4.9\end{array}$ & $\begin{array}{l}0.9 \\
.8 \\
2.2 \\
1.7 \\
1.5 \\
1.2\end{array}$ & $\begin{array}{l}.18 \\
.82 \\
.18 \\
.32 \\
.15 \\
.51\end{array}$ & $\begin{array}{l}23.8 \\
25.3 \\
38.8 \\
70.6 \\
15.6 \\
69.9\end{array}$ & $\begin{array}{r}19.5 \\
14.0 \\
17.8 \\
2.2 \\
10.0 \\
6.9\end{array}$ & $\begin{array}{l}9.7 \\
9.4 \\
9.6 \\
5.9 \\
8.7 \\
5.3\end{array}$ \\
\hline \multicolumn{8}{|c|}{ Analyst AE } \\
\hline $\begin{array}{l}51.85-54.80 \\
54.80-57.95 . \\
57.95-60.70 \\
60.70-64.05 \\
60.00-63.00 \\
64.05-67.10 \\
67.10-96.13 \\
93.13-99.18 \\
99.18-102.23 .\end{array}$ & & $\begin{array}{r}11.7 \\
11.2 \\
14.5 \\
12.9 \\
6.2 \\
7.0 \\
(2) \\
8.0 \\
5.9\end{array}$ & \begin{tabular}{r}
17.0 \\
17.6 \\
14.7 \\
25.1 \\
78.0 \\
77.0 \\
\hdashline 23.3 \\
68.0
\end{tabular} & $\begin{array}{r}0.8 \\
.7 \\
.7 \\
.7 \\
.2 \\
.2 \\
.8 \\
.8\end{array}$ & $\begin{array}{r}0.21 \\
.16 \\
.21 \\
.25 \\
.37 \\
.48 \\
.25 \\
.25\end{array}$ & \begin{tabular}{r}
164.3 \\
164.6 \\
163.3 \\
153.6 \\
14.7 \\
14.1 \\
\hdashline 146.9 \\
112.8
\end{tabular} & $\begin{array}{r}5.9 \\
5.5 \\
6.8 \\
7.3 \\
11.5 \\
12.0 \\
-5.1 \\
8.6\end{array}$ \\
\hline
\end{tabular}

1 This figure represents total insolubles.

2 No sample.

The northern area was being mined for bauxite in 1958. This bauxite lies under 1 to 2 meters of ferruginous soil and about 30 centimeters of hard, "cangalike" bauxite. The surface of the hard bauxite appears to be horizontal and to coincide with the 1,350-meter contour. This suggests that future exploration for bauxite in that area should test immediately below the plane defined by the 1,350-contour.

TABLE 24.-Analyses of bauxite, Macacos quadrangle, Minas Gerais, Brazil

September 25, 1956

[Source of information, St. John del Rey Mining Co. Type of sampling and exact location of samples not specified]

\begin{tabular}{|c|r|r||c|c|c|}
\hline $\begin{array}{c}\text { A vailable } \\
\mathrm{Al}_{2} \mathrm{O}_{3}{ }^{1}\end{array}$ & $\begin{array}{c}\text { Total } \\
\mathrm{SiO}_{2}\end{array}$ & $\begin{array}{c}\text { Reactive } \\
\mathrm{SiO}_{2}{ }^{2}\end{array}$ & $\begin{array}{c}\mathrm{Avalable} \\
\mathrm{Al}_{2} \mathrm{O}_{3}{ }^{1}\end{array}$ & $\begin{array}{c}\text { Total } \\
\mathrm{SiO}_{2}\end{array}$ & $\begin{array}{c}\text { Reactive } \\
\mathrm{SiO}_{2}{ }^{2}\end{array}$ \\
\hline 39.40 & 9.80 & 9.40 & 36.40 & .70 & .40 \\
29.00 & .70 & .40 & 32.70 & .50 & .20 \\
44.50 & .50 & .30 & 31.00 & .70 & .40 \\
47.90 & 1.50 & 1.30 & 26.20 & .70 & .50 \\
43.60 & .80 & .60 & 26.40 & .70 & .50 \\
44.70 & .40 & .20 & 20.10 & .50 & .20 \\
48.10 & .60 & .40 & & & \\
\hline
\end{tabular}

1 Available $\mathrm{Al}_{2} \mathrm{O}_{3}$ is that which can be extracted by the Bayer process, and not total alumina.

${ }_{2}$ Reactive $\mathrm{SiO}_{2}$ represents silicates which react in the Bayer process and are detrimental.

\section{CLAY}

Clay deposits occur in a number of places in areas of Quaternary and Tertiary alluvium. Some of the clay is suitable for, and is being used in, the manufacture of refractory brick. Magnesita S. A. kindly furnished the following analysis of the clay so used:

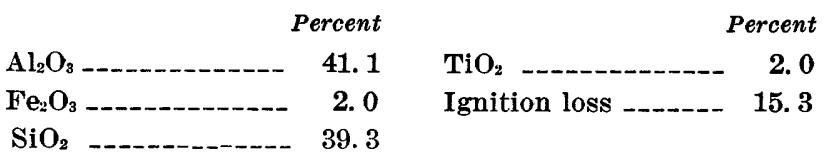

The source of the clay of this analysis is given only as St. John del Rey Mining Co. land, but it is highly probable that the pit at Macacos N. 8,300, E. 2,500 is the source because this was the only clay pit being worked in the area at the time these data were supplied.

The specifications for refractory clay used by Magnesita S. A. are that $\mathrm{Al}_{2} \mathrm{O}_{3}$ be more than 40 percent and that $\mathrm{Fe}_{2} \mathrm{O}_{3}$ be less than 3 percent.

Two of the best clay deposits in the Macacos quadrangle (N. 5,700, E. 2,000 and N. 5,600, E. 4,100) occur on the watershed of a stream which is the source of water for Belo Horizonte. The city has stopped exploitation of these deposits in order to protect its water supply.

The a verage of 12 analyses of the clay from different parts of the deposit at Macacos N. 5,700, E. 2,000 are shown below :

\begin{tabular}{|c|c|c|c|}
\hline & $\begin{array}{l}\text { Maximum } \\
\text { in } 12\end{array}$ & $\underset{12}{\text { Average of }}$ & $\underset{\text { in } 12}{\operatorname{Minimum}}$ \\
\hline $\begin{array}{l}\mathrm{Al}_{2} \mathrm{O}_{3} \\
\mathrm{Fe}_{2} \mathrm{O}_{3} \\
\mathrm{SiO}_{2} \mathrm{~T}_{2} \\
\mathrm{TiO}_{2} \mathrm{LSS}_{2}\end{array}$ & $\begin{array}{r}54.95 \\
10.20 \\
48.40 \\
2.84 \\
19.68\end{array}$ & $\begin{aligned} 48.57 \\
3.81 \\
44.62 \\
2.44 \\
15.72\end{aligned}$ & $\begin{array}{r}44.50 \\
1.77 \\
32.40 \\
2.04 \\
14.04\end{array}$ \\
\hline
\end{tabular}

Samples of pink clay and of white clay from the deposit at Macacos N. 5,600, E. 4,100 were analyzed separately. As might be expected, the pink clay contained more $\mathrm{Fe}_{2} \mathrm{O}_{3}$ than the white. The results are listed below: ${ }^{1}$

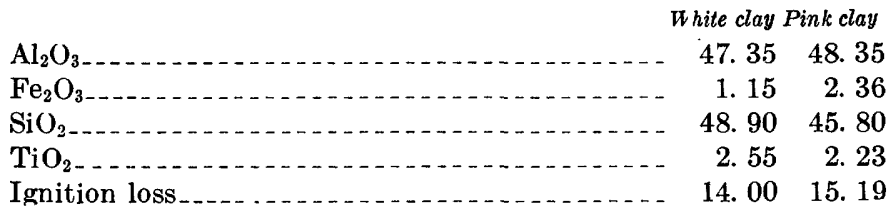

${ }^{1}$ Analyses, courtesy of St. John del Rey Mining Co. 
A small deposit of clay occurs near Corrego de Angú at Macacos N. 400, E. 8,200. An analysis of this material is given through courtesy of the St. John de] Rey Mining Co:

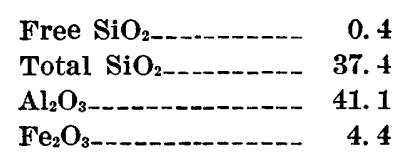

Several other deposits of clay occur in the Ibirite quadrangle and are shown on that map. They have not been exploited and no analyses are available. They are similar in appearance to those described above.

\section{BRICK CLAY}

Clay suitable for making common bricks occurs in small deposits throughout the Belo Horizonte, Ibirité, and Macacos quadrangles. The clay is commonly light to dark gray because of organic matter. In many brickyards it is mixed to proper consistency by primitive methods.

\section{ASBESTOS}

For several years asbestos has been mined on a small scale from the southeastern part of the Macacos quadrangle. The asbestos occurs in serpentinite both as cross-fiber veinlets and as slip fiber. The serpentinite body occupies several square kilometers in the southeastern part of the Macacos quadrangle and the southwestern part of the adjoining Rio Acima quadrangle (see fig. 40).

Most of the asbestos in the Macacos quadrangle occurs in the southern part of the serpentinite body.

The serpentinite is associated with medium-grained gabbro; both the gabbro and the serpentinite have been intruded into the Nova Lima group of the Rio das Velhas series, and both are probably older than rocks of the Minas series.

The gabbro in places near the gabbro-serpentinite contact has been altered to talc. In many places subsequent shearing has changed this talc "pseudomorph after gabbro" into talc schist.

The serpentinite consists almost entirely of antigorite, which in some thin sections can be seen to be pseudomorphous after olivine.

The asbestos mineral is bright-green chrysotile whose fibers are tough and flexible. Many veinlets contain cross-fiber 1.5 to 3 centimeters long, but most commonly the fibers in veinlets are 0.5 to 1.0 centimeter long.

Picrolite, a dark-green, brittle, fibrous mineral occurs along shears. It may be as much as 1 meter thick along some shears, although 5 to 30 centimeters is most common.
Talc occurs as veinlets and as coatings on joints in the serpentinite, especially near the gabbro. Several talc veinlets appear to be pseudomorphous after chrysotile, but it is not possible to prove this and the structure may be coincidental.

Magnesite occurs sparsely as veins and veinlets 1 to 5 centimeters thick. Generally it is pale cream to pale brown.

Magnetite is not common but it was found as scattered anhedral grains in the serpentinite.

It is noted in old records of the St. John del Rey Mining Co. that a little chromite as well as a few tiny grains of platinum were recovered by panning of the sand from a creek draining the serpentinite area. Neither mineral was seen by the present author.

\section{MAJOR UNDERGROUND WORKINGS}

"Old Mine."-Little can be reported on the "Old Mine" because it was flooded and inaccessible at the time the writer was working in the area. The open pit part of the "Old Mine" still contains veinlets of good fiber, and recent drilling indicates that this area is still one of the most promising.

From 1945 to 1948 the "Old Mine" yielded 928 tons of fiber.

Mine 1.-From 1949 to 1955 one-half of the production came from Mine 1 (fig. 41).

Mine 6.-Only part of Mine 6 (fig. 42) could be mapped because the western and the northeastern parts were flooded. The mine superintendent reported that little or no asbestos was found in the areas that are now flooded.

Cruzeiro mine.-The most important mine in the area is the Cruzeiro mine (see pl. 13). More asbestos and of longer fiber can be seen in this mine than in any of the others. Several veinlets with fibers 3 centimeters long occur in the workings about 5 meters above the main level.

The contact between serpentinite and gabbro that has been altered to talc is exposed in the western drift from the main level.

Raposal mine.--This mine was begun in the hopes of finding an extension of the ore zone from the "Old Mine". The Raposal mine (see fig. 43) has produced a considerable amount of useful asbestos, but it had not (at the time of mapping in 1956) found an ore zone equal to that reported from the "Old Mine."

Conclusions from underground mapping.-A study of the maps of the Cruzeiro mine, Mine 1, and Mine 6 shows two rather definite trends of the asbestos-bearing 


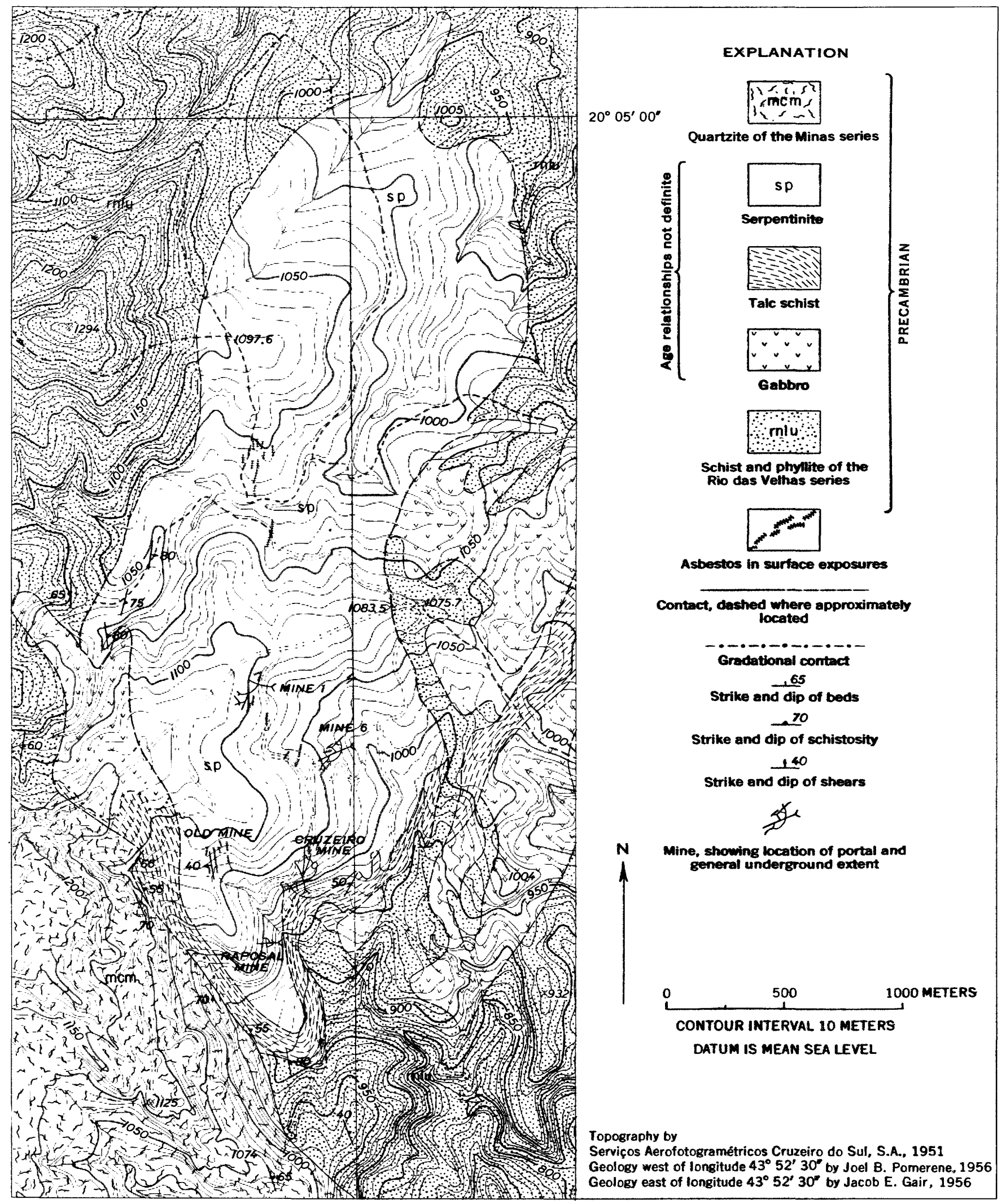

$43^{\circ} 52^{\prime} 30^{\prime \prime}$

Figorw 40.- Geologic map of the serpentinite area, Macacos and Rio Acima quadrangles, Minas Gerais, Brazil. 


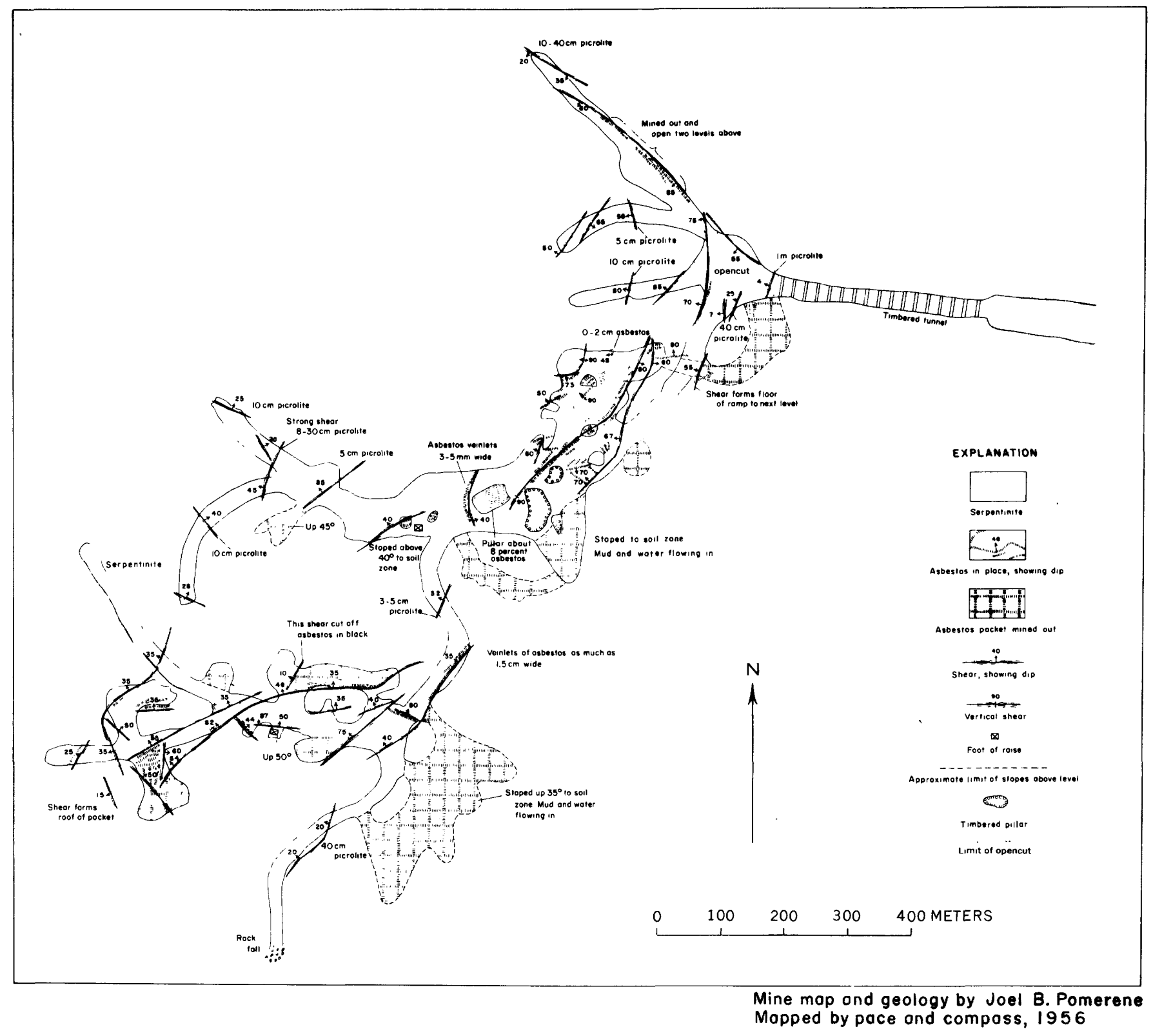

Figure 41.-Geologic map of Mine 1, Sociedade Brasileira de Mineração Fama, Ltda. Serpentinite area, Macacos quadrangle. 


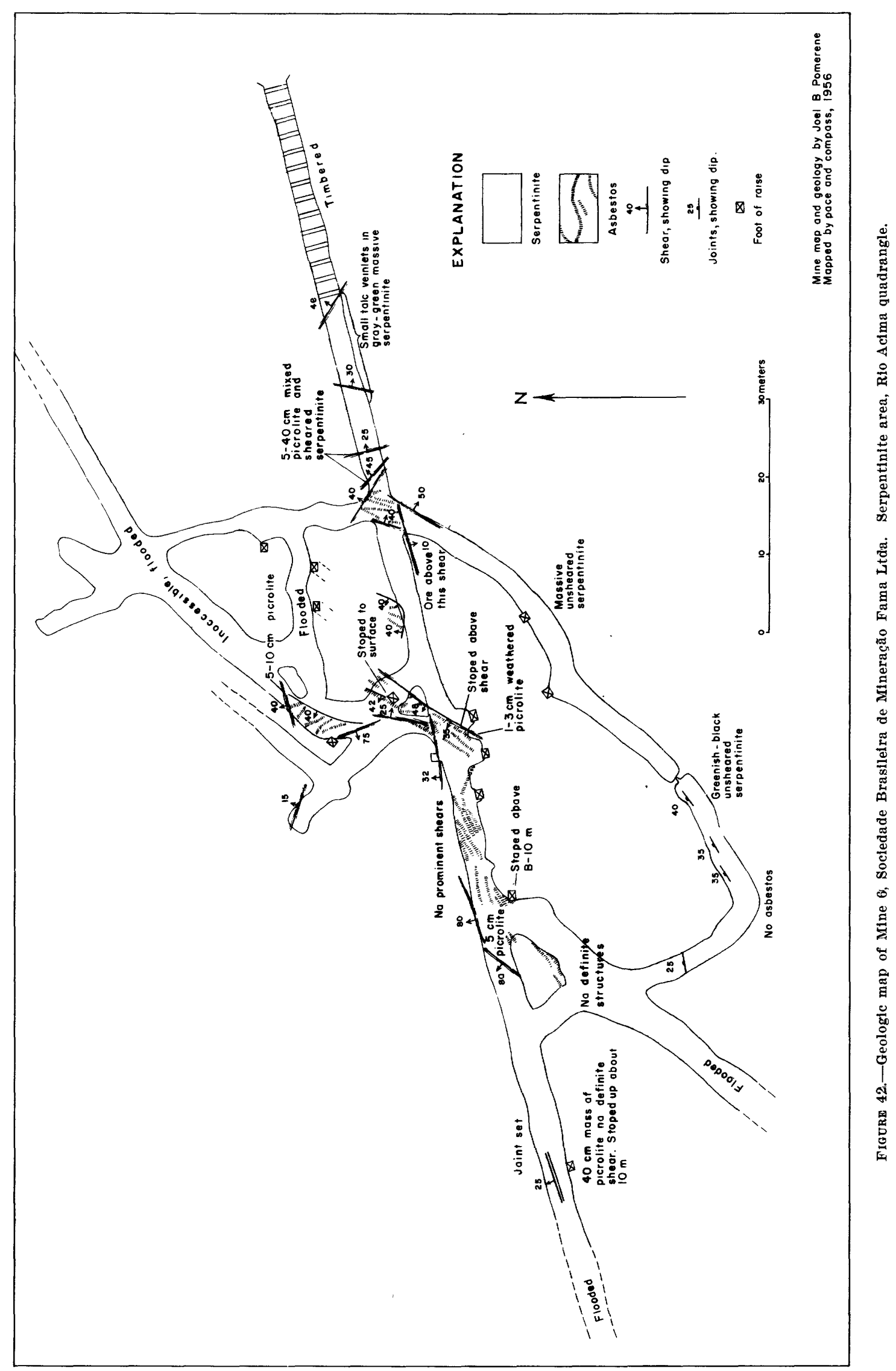




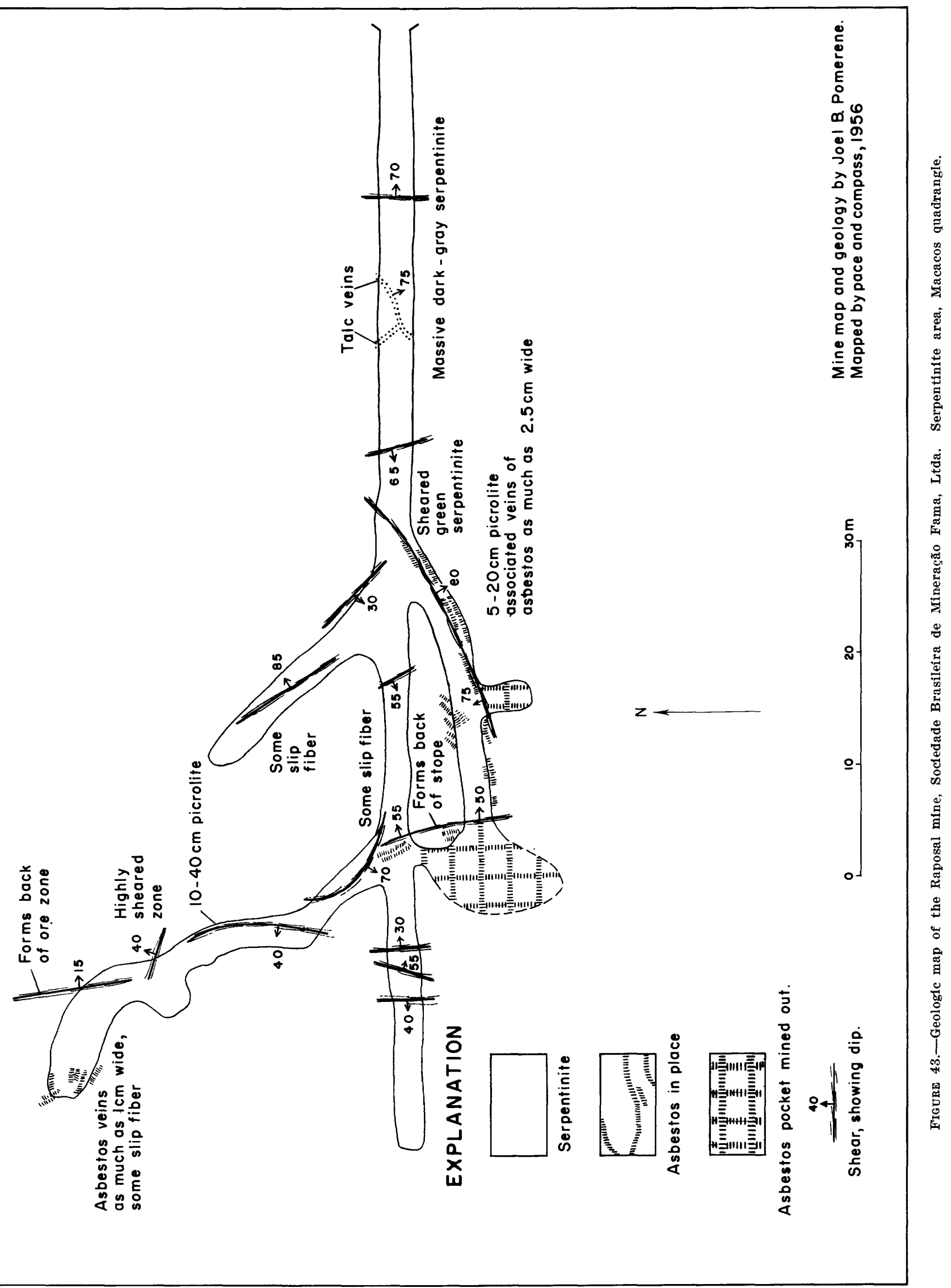


zones. Although rarely can any one asbestos vein be followed more than a few tens of meters, vein-bearing zones seem to follow two directions, N. $45^{\circ} \mathrm{E}$. and $\mathrm{N}$. $10^{\circ} \mathrm{E}$. The zone that trends N. $10^{\circ} \mathrm{E}$. is along the contact with the gabbro. This is the zone in which the "Old Mine" was worked, and recent drilling indicates that it is still relatively rich in asbestos.

Away from the gabbro-serpentinite contact the zones in which veins generally trend N. $45^{\circ} \mathrm{E}$. suggest that exploration should consist of fans of horizontal drill holes oriented generally northeastward, beginning at any rich pocket of asbestos. Even though the pocket is worked out, the chances of finding more asbestos appear better if exploration is carried N. $45^{\circ}$ E. from known occurrences.

Drilling.-Twenty-three diamond-drill holes were put down between the ricinity of the Raposal mine and the vicinity of Mine 1. Dr. A. Colomb (written communication, 1956) has studied the cores and has estimated a reserve of 18,000 tons of short fiber asbestos, from 1 to 6 millimeters long (class 5D-7D) (after milling). He based his calculations on a zone 10 meters wide and 100 meters deep, extending from near the Raposal mine to near the north end of the "Old Mine."

Production.-From 1945 to 1955 , a total of 2,730 tons of asbestos fiber from this area was mined and milled. The mines were closed for $41 / 2$ years of this period. The following tabulation shows yearly production of fiber in metric tons.

\begin{tabular}{|c|c|c|c|}
\hline Year & Tons & Year & T'ons \\
\hline 1945 & 210.40 & 1951 & (1) \\
\hline 1946 & 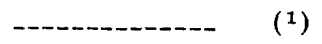 & 1952 & $\left({ }^{1}\right)$ \\
\hline 1947 & 398.55 & 1953 & 2 \\
\hline 1948 & 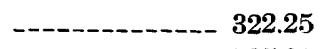 & 1954 & -156.50 \\
\hline 1949 & - 595.90 & 1955 & $-\ldots$ \\
\hline 1950 & $-(1)$ & Tot & tal _..._... $2,732.50$ \\
\hline
\end{tabular}

In 1955,4 tons of fiber were recovered for every 100 tons of ore milled. If waste rocks removed in mining were counted, the asbestos recovery would be 2.40 percent.

The above production data were made available to the author by the courtesy of Dr. Colomb.

It should be pointed out that the mill is only a pilot plant, and it was not designed for continuous hearyduty production.

So far no attempt has been made to save the long fibers, some of which are of spinning grade. The milling process reduces all the fibers to the relatively low classification of $5 \mathrm{D}$ to $7 \mathrm{D}$.

The asbestos is used in manufacture of corrugated asbestos-concrete roofing, asbestos-concrete pipe and fittings, and similar products.

\section{GOLD}

Gold occurs in many places in the basal conglomerate of the Moeda formation. Prospect pits show that the chief occurrence of gold was in the conglomerate and not in the quartzite. Where the basal beds of the Moeda formation are quartzite, there are no pits. This suggests that the gold-bearing conglomerate is a "fossil" placer and that its gold, because of its high specific gravity, was deposited with heavier rock fragments of the conglomerate rather than with sand of the quartzite.

These deposits were extensively prospected at one time as shown by many open pits, by water-supply canals, and by old cobblestoned mule trails leading to them. However, even though the conglomerate in many places contains several grams of gold per ton, it is not economically feasible to mine it at the present time.

Placer gold is present also in many of the Tertiary and Quaternary terrace gravels. Most of these gravels, including those near the village of Macacos, and those southwest of the Rochedo das Gaivotas in the Ibirité quadrangle have been worked for gold.

\section{MANGANESE}

There are no large manganese mines in the Belo Horizonte, Ibirité, and Macacos quadrangles. Innumerable prospect pits were opened, presumably when the price of ore was high. None of these prospects was developed into a major manganese mine, but many yielded a few to a few tens of tons of saleable ore after hand picking and cobbing.

Most manganese showings of any promise occur in the upper part of the Cauê itabirite, in the Gandarela formation, or in the overlying Cercadinho formation.

The best manganese mine in these three quadrangles and the only one in operation at present (mid-1958) is that known as Capitão do Mato at Macacos N. 100, E. 7,550. Even in this mine the ore requires hand picking and cobbing to obtain approximately a grade of 40 percent manganese. The deposit occurs in weathered dolomitic rocks of the Gandarela formation close to the contact with Cauê itabirite. The ore probably is a residue from the leaching of manganiferous dolomite. Solution and redeposition by ground water have resulted in the formation of botryoidal crusts and masses of manganese oxide which make up the shipping ore after hand separation.

In the Cercadinho formation pits and short adits have followed traces of manganese, but no large mines have been developed. Intensive exploration has scarred the hillsides at Ibirité N. 6,200, E. 5,700, and N. 8,700-E. 9,800 , yet none of the pits or adits has been enlarged beyond the exploration stage. The Cercadinho formation at this place contains an unusual number of dolomite lenses. These are manganiferous and have been 
weathered and leached so that only "black splash" rock remains at or near the surface. Nearly every prospect shows some of this material. Probably solution of some of the black splash rock provided the manganese which was deposited as botryoidal crusts on fracture faces and bedding planes of the interbedded quartzite.

Along the north side of the Serra do Curral, where the beds are sharply orerturned, the manganese prospects in the Cercadinho formation are near the stratigraphic base of the formation. The Ceradinho formation in this locality apparently lacked lenses of manganiferous dolomite, but the physiographically higher and stratigraphically underlying manganiferous dolomitic rocks of the Gandarela formation have weathered to black splash rock or to soft, manganiferous, dolomitic itabirite, and apparently have been the source of the manganese which forms encrustations in joints and fractures in the quartzite.

\section{BUILDING MATERIATS}

Granite and granite gneiss are extensively quarried in the vicinity of Belo Horizonte for concrete aggregate and for paving stones. Most of the paving blocks and curbstones in Belo Horizonte seem to be of the Prado Lopes type granite gneiss; at present, however, this rock is quarried and crushed mainly for use as concrete aggregate.

None of the granite or granite gneiss is cut and polished for use as dimension stone.

Dolomite from the Belo Horizonte, Ibirité, and Macacos quadrangles is used only chemically; none, at present, is quarried for building or for ornamental use. Else where in the Quadrilátero Ferrífero, much dolomite is sawed into slabs and polished for use as table tops, bar tops, and ornamental building trim.

Sand for use in concrete is obtained locally by sifting stream sediments; a small amount has been quarried from outcrops of weathered quartzite of the Cercadinho formation. Iron formation rubble containing 50 to 60 percent iron commonly is used for road gravel, which makes excellent road surfacing material because its dust is relatively heavy in comparison to dust from other kinds of rock. On some parts of older roads it has a tendency to become cemented into canga.

\section{LITERATURE CITED}

Barbosa, O., 1954, Evolution du Geosynclinal Espinhaço: Internat. Geol. Cong., 19th, Algiers, 1952, sec. 13, pt. 2, p. 17-36.

Barth, T. F. W., 1952, Theoretical Petrology : New York, Wiley, p. 288.

Brajnikov, B., 1947, Essai sur la tectonique de la région à l'Este de Belo Horizonte, Minas Gerais, Brazil : Soc. Géol. France Bull., $5^{\circ}$ Serie, 17, p. 321-335.
Derby, O. A., 1906, The Serra do Espinhaço: Jour. Geology, v. 14 , no. 5, p. 374-101.

Dorr, J. V. N. 2d, 1958, The Cauê itabirite, a symposium on the stratigraphy of the Minas series in the Quadrilatero Ferrifero Minas Gerais, Brazil : Bol. Soc. Bras. Geol., v. 7, no. 2, p. 61-62.

Dorr, J. V. N. 2d, and Barbosa, A. L. M., 1963, The geology and ore deposits of the Itabira district, Minas Gerais, Brazil : U.S. Geol. Survey Prof. Paper 341-C.

Dorr, J. V. N. 2d, Gair, J. E., Pomerene, J. B., and Rynearson, G. A., 1957, Revisão da Estratigrafia Precambriana do Quadrilátero Ferrifero, Minas Gerais, Brazil: D.F.P.N. Avulso 81, Rio de Janeiro.

Dorr, J. V. N. 2d, Guild, P. W., and Barbosa, A. L. M., 1952, The iron ore deposits of Brazil, Origin of the Brazilian iron ores, Symposium sur les gisements de Fer du Monde: Internat. Geol. Cong., 19th, Algiers, v. 1, p. 286-298.

Gair, J. E., 1958, The Sabara formation, a symposium on the stratigraphy of the Minas series in the Quadrilatero Ferrifero, Minas Gerais, Brazil : Bol. Soc. Bras. Geol., v. 7, no. 2, p. 68-69.

1958, Age of gold mineralization at the Morro Velho and Raposos mines, Minas Gerais: Bol. Soc. Bras. Geol., v. 7, no. 2 , p. $39-45$.

1962, Geology and ore deposits of the Nova Lima and Rio Acima quadrangles, Minas Gerais, Brazil: U.S. Geol. Survey Prof. Paper 341-A, p. A1-A67.

Gorceix, Henri, 1884, Bacias terciarias d'agua doce nos arredores de Ouro Preto, Minas Gerais, Brazil : An. Esc. Minas, Ouro Preto, no. 3, p. 95-114.

Guild, P. W., 1953, Iron deposits of the Cougonhas district, Minas Gerais, Brazil : Econ. Geology, v. 48, no. 8, p. 639-676.

1957, Geology and ore deposits of the Congonhas district, Minas Gerais, Brazil: U.S. Geol. Survey Prof. Paper 290, $90 \mathrm{p}$.

Guimarães, Djalma, 1931, Contribuição a geologia do Estado de Minas Gerais: Rio de Janeiro, Serv. Geol. Mineralogico de Brazil, Bol. 55, 36 p.

Harder, E. C., and Chamberlin, R. T., 1915, The geology of Central Minas Gerais, Brazil: Jour. Geology, v. 23, nos. 4 and 5, p. 341-384 and 385-424.

Henwood, W. J., 1871, Observations on metalliferous deposits : Trans. Royal Geol. Soc. of Cornwall, v. 8, pt. 1, Penzance, $916 \mathrm{p}$.

Herz, Norman, 1958, Rochas igneas: Guia geologico e roteiro das excursoes para o 12th congresso anual da Sociedade Brasileira de Geologia, Belo Horizonte.

Herz, Norman, and Dutra, C. V., 1958, Preliminary spectrochemical and age determination results on some granitic rocks of the Quadrilátero Ferrifero, Minas Gerais, Brazil : Bol. Soc. Bras. Geol., v. 7, no. 2, p. 81-95.

Johnson, R. F., 1962, Geology and ore deposits of the Cachoeira do Campo, Dom Bosco, and Ouro Branco quadrangles, Minas Gerais, Brazil : U.S. Geol. Survey Prof. Paper 341-B, p B1-B39.

Maxwell, C. H., 1958, Batatal formation, Symposium on the stratigraphy of the Minas series in the Quadrilatero Ferrífero, Minas Gerais, Brazil : Bol. Soc. Bras. Geol., v. 7, no. 2, p. 60-61.

Oliveira, A. I. de, 1956, Chapter on Brazil in the Handbook of South American geology, Wm. F. Jenks, ed. Geol. Soc. America, Mem. 65, p. 8. 
Pomerene, J. B.. 1958, The Cercadinho formation, a symposium on the stratigraphy of the Minas series in the Quadrilátero Ferrifero, Minas Gerais, Brazil: Bol. Soc. Bras. Geol., v. 7, no. 2, p. 64-65.

-1958 , The Taboões quartzite, a symposium on the stratigraphy of the Minas series in the Quadrilatero Ferrifero, Minas Gerais, Brazil: Bol. Soc. Bras. Geol., v. 7, no. 2, p. 66-67.

1958, The Barreiro formation, a symposium on the stratigraphy of the Minas series in the Quadrilatero Ferrifero, Minas Gerais, Brazil: Bol. Soc. Bras. Geol., v. 7, no. 2, p. 67-68.
Rynearson, G. A., Pomerene, J. B., and Dorr, J. v. N., 2d, 1954, Contacto basal da série de Minas na parte occidental do Quadrilátero Ferrifero, Minas Gerais, Brazil : Avulso 34, Div. de Geologia, DNPM, Rio de Janeiro, $18 \mathrm{p}$.

Simmons, G. C., 1958, The Fecho do Funil formation, a symposium on the stratigraphy of the Minas series in the Quadrilátero Ferrífero, Minas Gerais, Brazil: Bol. Soc. Bras. Geol., v. 7, no. 2, p. 65-66.

Wallace, R. M., 1958, The Moeda formation, a symposium on the stratigraphy of the Minas series in the Quadrilatero Ferrifero, Minas Gerais, Brazil: Bol. Soc. Bras. Geol., v. 7 , no. 2 , p. $59-60$. 



\section{INDEX}

[Where several page numbers appear, major references a rel in italic]

A

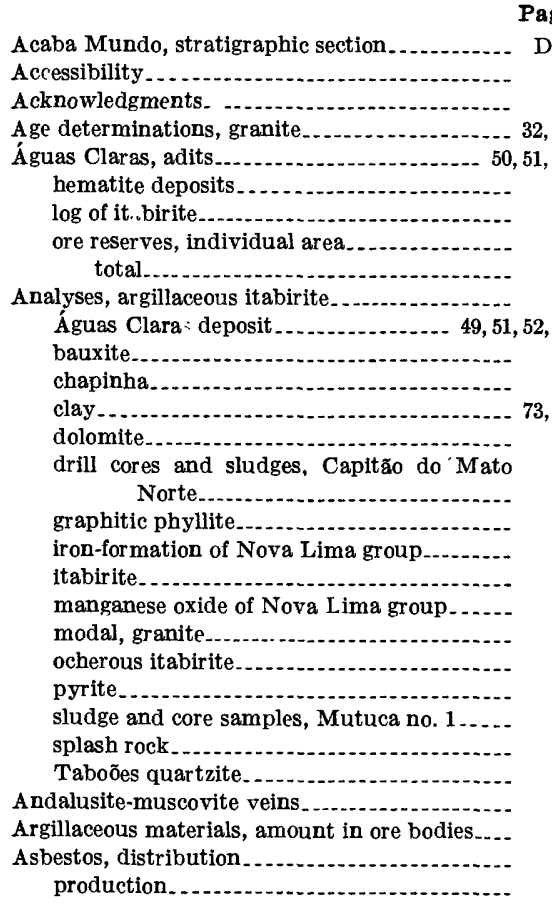

B

Barrelro deposit, ore reserves.

Barreiro formation.

Batatal formation, litho

Bauxite.

Boulder mine.

Building materials

\section{$\mathrm{C}$}

Canga.

Canga rica-

Capão Xavier,

Capitão do Mato, manganese

Caraça group.

Cauo itabirite, compared to Nova Lima group. lithology. siliceous types.

Carvalho, Elenora Leitão de, analyst. ............

Cercadinho formation, ferruginous quartzite....

Cercadinho formation, hematite concretions....

lithology

manganese. -

white quartzite

Chapinha

Chlorit

Clay ....

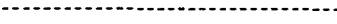

Conclusions, from underground mapping of asbestos.
Page

Conglomerate, Cercadinho formation........... D22

Conglomerate-quartzite sequence................ 9

Copper minerals, in dolomite.................... 18

Crossbedding....................................... 23

Cruzeiro mine...... 34,74

$\mathrm{D}$

Diamond-drill holes.................. 18, 49, 50, 72, 79

Dicotyledonous leaves............................ $\quad 29$

Dikes ....................... 34, 35

Dolomite, description. . . . economic use.

Dolomitic itabirite .

Drainage........................................... 3

Dutra, Claudia, analyst........ 8

E

Economic geology .......................... 28, 41, 80

Espinola, Aida, analyst................. 27, 43, 72, 73

F

Faults.

Fazenda Conde, ore reserves

Fazenda da Jangada, canga

Fecho do Funil formation

Feixos area, dolomite.

ore reserves

Fieldwork

$37,40,44,60$

Fossils.................... 28, 29

Fuchsite

G

Gandarela formation, lithology. relation to CauA itabirite . . . . relation to Cercadinho formation.......... 24

Geologic history .................. 41

Geology, general

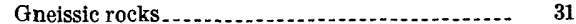

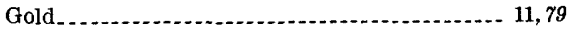

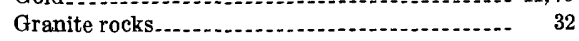

Graphitic beds............................... 26, 27

Guild, P. W., quoted.......................... 43, 44

H

Hematite, amount in ore bodies Cercadinho formation. (16 high-grade ore. microtexture. specular.

\section{I}

Igneous rocks

Inclusions, in quartz

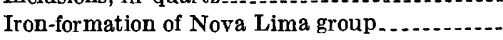
Iron ore, definition.

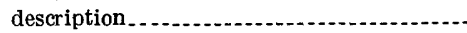

Ironstone.

Itabira group.
Page

tabirite, definition dolomitic..................................... 19

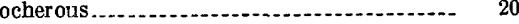

soft

surficially enriched

See also Cane itabirite.

Itacolomi series

Joints

L

Lagoa Miguelaõ, fossils..._... 29

Lagõa Seca. ... . Laterite. . . . . .

Leaching ....................................... 43, 44

Limonite, iron-formation of Nova Lima group.. Location.

M

Macacos, granite.

Magnesite.....................

Magnetite, amount in ore bodies in serpentinite

Maio, Narzy, analyst.

Manganese.

Mannesmann adits, analyses of itabirite

Mannesmann adit 1 , leaching

Mannesmann mine 2, folds ........................

Matos, Francisco Coutinho de, analyst.........

Metagabbro................................................

Metamorphism............................... 33, 35, 36

Metasedimentary rocks, indeterminate age..... 28

Metasomatic replacement........................ 44

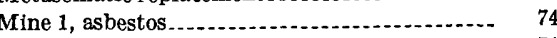

Mine 6, asbestos.................................. 74

Mineralogy, diabasic dikes..................... 35

Minas series. .......................................... 10

Moeda formation, lithology

relation to grinite. ......................... 32

Moeda syncline, relation to Caraca group....... 11

relation to Caue itabirite. . . . . .

Tertiary and Quaternary rocks ............

Morro do Pedra granite

Mudstone, Tertiary ...................... 30,

Mutuca no. 2 deposit, ore reserves.............. 60

Mutuca no. 1, ore reserves

\section{$\mathbf{N}$}

Nova Lima group, iron-formation. ..............

lithology

relation to Moeda formation..................

Novaculite.

\section{0}

Octahedrite, in quartz................................

old Burnier mine..................................

old Mine, asbestos 18

Ore. See Iron ore.

$\mathbf{P}$

Pedra de amolar

Periods of deformation 


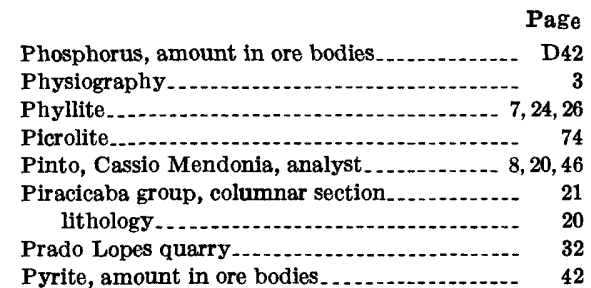

\section{Q}

Quartz, amount in ore bodies solution.

Quartzite, Cercadinho formation. Quaternary sediments.

Railroads

Rainfall

Ramos, Maria Yelsa Esteves, analyst

Raposal mine.

Replacement or

Reserves, Á guas Claras deposit

estimates.

Jangade deposit

Zoroastro Passos .................................

$$
\text { Gama. }
$$

Rice grit..........................................

Rio do Peixe, dolomite.

Page

4,26

46

21

32

42
Sabará formation

Samambaia hematite deposit, description -...-. ore reserves, individual area. total

Sand, economic use

Sandstone

Serpentinite.

Serra da Jangada, rubble ore .....................

Serra da Rola Moça, dolomitic itabirite......

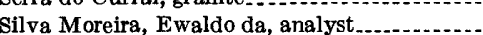

Splash rock.

Staurolite schist

Stratified clay

Stratigraphic section, Barreiro formation

Gandarela formation.

iron-formation of Nova Lima group..........

location...

$48,49,50,51$,

metasedimentary rocks

Taboões quartzite............ 25, 26, 28

Stratigraphy
Page

D5

11

3

46

46
35

55

56

4,74

46

19

32

72

18

28

29

26

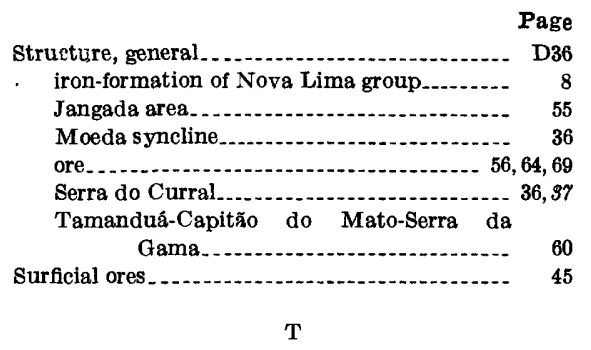

Taboões quartzite

Talc, amount in ore bodies

in serpentinite...... 74

Talc schist ............ 34

Tamanduá-Capitão do Mato-Serra da Gama, reserves.

structure

Taquaril, ore reserves....................... 45, 47

Temperature, ore formation. .................. 43

seasonal. .

Terrace gravels

Tertiary sediments............ 28, 57

$\mathrm{V}$

Vegetation

Veiga, Edmir Elias, analyst.................... 19

Veins

Z

Zoroastro Passos, ore reserves 


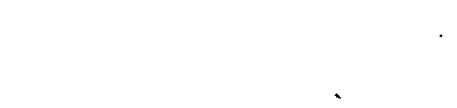

